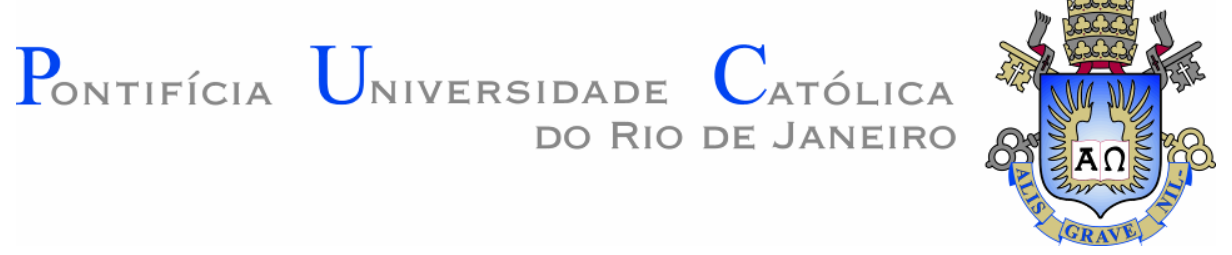

Thamiris Bastos Lopes

\author{
Outras Formas de Conhecer o Mundo: \\ Educação Infantil em Museus de Arte, Ciência e História
}

Tese de Doutorado

Tese apresentada como requisito parcial para a obtenção do grau de Doutor pelo Programa de PósGraduação em Educação do Departamento de Educação da PCU-Rio.

Orientadora: Prof. ${ }^{\text {a }}$ Maria Cristina Monteiro Pereira de Carvalho

Rio de Janeiro

Janeiro de 2019 


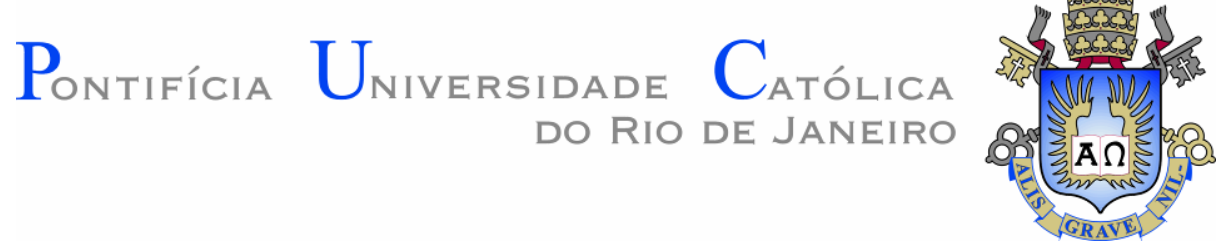

Thamiris Bastos Lopes

\section{Outras Formas de Conhecer o Mundo: Educação Infantil em Museus de Arte, Ciência e História}

Tese apresentada como requisito parcial para a obtenção do grau de Doutor pelo Programa de PósGraduação em Educação do Departamento de Educação do Centro de Teologia e Ciências Humanas da PUC-Rio. Aprovada pela Comissão Examinadora abaixo assinada.

\section{Prof‥ Maria Cristina Monteiro Pereira de Carvalho \\ Orientadora \\ Departamento de Educação - PUC-Rio \\ Profa. Sonia Kramer Departamento de Educação - PUC-Rio}

Prof. Ralph Ings Bannell Departamento de Educação - PUC-Rio

Profa. Sibele Cazelli Ministério da Ciência e Tecnologia, Inovações e Comunicações

Profa. Isabel Victória Corrêa Van Der Ley Lima Colégio de Aplicação da - CAP/UFRJ

Profa. Monah Winograd Coordenadora Setorial do Centro de Teologia e Ciências Humanas - PUC-Rio

Rio de Janeiro, 07 de janeiro de 2019 
Todos os direitos reservados. É proibida a reprodução total ou parcial do trabalho sem autorização da universidade, da autora e da orientadora.

Thamiris Bastos Lopes

Possui graduação em Pedagogia pela Universidade do Estado do Rio de Janeiro (UERJ) e mestrado em Museologia e Patrimônio pela Universidade Federal do Estado do Rio de Janeiro (UNIRIO). É integrante do Grupo de Estudo e Pesquisa em Educação, Museu, Cultura e Infância (GEPEMCI) do Departamento de Educação da Pontifícia Universidade Católica do Rio de Janeiro (PUC-Rio).

Ficha Catalográfica

Lopes, Thamiris Bastos

Outras formas de conhecer o mundo : educação infantil em museus de arte, ciência e história / Thamiris Bastos Lopes ; orientadora: Maria Cristina Monteiro Pereira de Carvalho. - 2019.

221 f. : il. color. ; $30 \mathrm{~cm}$

Tese (doutorado)-Pontifícia Universidade Católica do Rio de Janeiro, Departamento de Educação, 2019.

Inclui bibliografia

1. Educação - Teses. 2. Infância. 3. Educação infantil. 4. Experiência estética. 5. Museu. I. Carvalho, Maria Cristina Monteiro Pereira de. II. Pontifícia Universidade Católica do Rio de Janeiro. Departamento de Educação. III. Título. 


\section{Agradecimentos}

O presente trabalho foi realizado com apoio da Coordenação de Aperfeiçoamento de Pessoal de Nível Superior - Brasil (CAPES) - Código de Financiamento 001.

Agradeço ao Programa de Pós-Graduação em Educação (PPGE/PUC-Rio) e a todos os seus professores pelos aprendizados e pela convivência.

Agradeço à banca examinadora deste trabalho, em especial às professoras Sonia Kramer e Sibele Cazelli, que participaram dos exames de qualificação, contribuindo com orientações valiosas para a construção desta tese.

Agradeço ao Museu de Arte do Rio, a Casa da Ciência da UFRJ e ao Museu Casa de Rui Barbosa, principalmente às equipes dos setores educativos, que aceitaram fazer parte deste estudo abrindo suas portas de forma colaborativa e acolhedora.

Agradeço aos professores e às crianças que participaram da pesquisa. A contribuição de vocês foi rica e valiosa, sem ela, esse estudo não existiria.

Agradeço imensamente à minha orientadora Cristina Carvalho, por compartilhar seus saberes, força, cuidado e carinho com minha pesquisa e comigo ao longo desta jornada.

Agradeço aos colegas do GEPEMCI pelas contribuições e espaços de debate de pesquisa em equipe.

Agradeço a todos os meus amigos pela paciência e compreensão das minhas ausências.

Agradeço às famílias Bastos, Lopes e Alcântara pelo afeto, cuidado, força e compreensão nos momentos mais difíceis.

Agradeço (sem palavras que mensurem) o apoio incondicional do Hudson dos Santos de Alcântara, por ser meu companheiro, meu amor, meu amigo. Essa conquista é nossa! 


\section{Resumo}

Lopes, Thamiris Bastos; Carvalho, Maria Cristina Monteiro Pereira de (orientadora). Outras formas de conhecer o mundo: Educação Infantil em Museus de Arte, Ciência e História. 2019. Rio de Janeiro. 221 p. Tese de Doutorado - Departamento de Educação, Pontifícia Universidade Católica do Rio de Janeiro.

O presente trabalho tem como objetivo conhecer a relação entre o público de Educação Infantil e os museus, buscando compreender quais aspectos possibilitam e dificultam esse encontro. Historicamente, o conceito e o olhar sobre a infância foram se modificando e influenciando diretamente as políticas públicas voltadas ao atendimento das peculiaridades apresentadas nessa etapa da vida. Perceber as crianças enquanto cidadãos, sujeitos sociais e históricos, produtores de cultura é condição para que se atue no sentido de favorecer seu crescimento e constituição. Compreendendo que as experiências com as expressões culturais diversas levam a criança a interagir e se apropriar do mundo, construindo significações e estabelecendo inúmeras relações, os museus - lugares que guardam diferentes saberes culturais produzidos pela humanidade - são espaços que podem contribuir para sua formação. Investigar a temática implica estar atento a essa relação em sua integralidade, considerando os diferentes agentes nela envolvidos: crianças, professores e educadores dos museus. Para tanto, foi priorizada uma investigação qualitativa, com realização de pesquisa de campo em museus de tipologias distintas, localizados na cidade do Rio de Janeiro. Questionário online, observação, entrevista e análise documental foram utilizados como ferramentas metodológicas para a realização do estudo. A reflexão acerca da formação humana, pautada nas experiências em meio à cultura e às manifestações culturais, artísticas e estéticas teve como alicerce as perspectivas teóricas de Benjamin, Dewey e Vigotski. Autores da área da Estética, Educação, Infância e Museologia também contribuíram para o constructo teórico da pesquisa. Os resultados apontam que, para proporcionar experiências estéticas para o público infantil nos museus, têm sido necessário enfrentar alguns obstáculos teóricos, financeiros e estruturais por parte das escolas 
e dos museus. Além disso, ainda são poucas as pesquisas que se dedicam a estudar o tema. Conclui-se que a experiência estética nos espaços museais se constitui na interação com as manifestações, registros e celebração das diferentes formas de viver e estar no mundo. Desta forma, os museus podem ser compreendidos enquanto meio - experimental e criativo - profícuo para promover experiências estéticas às crianças a partir da interação com a cultura material. Para tanto, é necessário que se amplie a relação entre museu, escola e universidade com o intuito de diminuir a lacuna entre os estudos sobre a infância e as práticas educativas com as crianças nos espaços culturais.

\section{Palavras-Chave}

Infância; Educação Infantil; Experiência Estética; Museu 


\section{Abstract}

Lopes, Thamiris Bastos; Carvalho, Maria Cristina Monteiro Pereira de (Advisor). Other ways to know the world: Early Childhood Education in Museums of Art, Science and History. Rio de Janeiro, 2019. 221 p. Tese de Doutorado - Departamento de Educação, Pontifícia Universidade Católica do Rio de Janeiro.

The objective of this study is to understand the relationship between the children's education audience and the museums, trying to comprehend which aspects enable and/or hamper this encounter. Historically, the concept and the look on childhood have been changing and directly influencing public policies aimed at attending to the peculiarities presented at this stage of life. Perceive children as citizens, social and historical subjects, producers of culture is a condition for it to act in favour of its growth and constitution. Understanding that experiences with diverse cultural expressions lead the child to interact and take ownership of the world by building meanings and establishing numerous relationships, museums places that hold different cultural knowledge produced by humanity - are spaces that can contribute to their formation. Investigating the theme implies being attentive to this relationship in its entirety, considering the different agents involved in it: children, teachers and museum educators. Therefore, qualitative research was prioritised, with the accomplishment of field research in museums of different typologies, located in the city of Rio de Janeiro. The online questionnaire, observation, interview and documentary analysis were used as methodological tools to carry out the study. The reflection on human formation, based on experiences in the midst of culture and cultural, artistic and aesthetic manifestations, was based on the theoretical perspectives of Benjamin, Dewey and Vygotsky. Authors from the area of Aesthetics, Education, Childhood and Museology also contributed to the theoretical construct of the research. The results pointed out that, to provide aesthetic experiences for children's audiences in museums, it has been necessary to face some theoretical, financial and structural obstacles. Also, there are still few studies dedicated to studying the subject. It is concluded that the aesthetic 
experience in the museum area is the interaction with the manifestations, records and celebration of the different ways of living and being in the world. In this way, museums can be understood as a means, experimental and creative, useful to promote aesthetic experiences to children from the interaction with material culture. It is necessary to broaden the relationship between museum, school and university to bridge the gap between the theory of studies on childhood and educational practices with children in cultural spaces.

\section{Keywords}

Childhood; Early Childhood Education; Aesthetic Experience; Museum 


\section{Sumário}

1.Introdução 15

1.1 Questões, objetivos e metodologia 16

1.2 Levantamento bibliográfico e principais referenciais 18 teóricos

1.3 Estrutura da tese

2. Experiência estética, infância e museu 24

2.1 Relações entre experiência, estética e conhecimento 24

2.1.1 Especificidade da experiência estética 27

2.1.2 A experiência estética enquanto dimensão educativa na 33 formação humana

2.2 Infância, educação infantil e estética

2.2.1 Infância e a dimensão estética do conhecimento

2.2.2 Educação Infantil e a experiência estética 48

2.3 A dimensão estética do conhecimento em museus e suas 55 relações com o público infantil

2.3.1 Democratização dos museus e público infantil

2.3.2 Dimensão estética e a sensibilidade do olhar

3. Os museus da cidade do Rio de Janeiro e o público de Educação Infantil

3.1 Metodologia da pesquisa

3.2 Quando os pequenos cariocas visitam os museus e centros culturais da cidade

3.3 Os museus de arte, ciência e história escolhidos como lócus da pesquisa

3.4 Espaço expositivo - possibilidades de mobilidade, autonomia, brincadeira e expressão?

3.5 Programas, atividades e metodologias

3.6 A formação de mediadores para atuar com o público infantil

4. Crianças, exposições, professores e mediadores

4.1 A relação estabelecida pelos museus com o público infantil

4.1.1 $\mathrm{O}$ que os educadores dos museus falam sobre as crianças

4.1.2 As constatações observadas na prática com crianças 
4.2 Crianças e a experiência museal

4.2.1 Expectativas, reações e os principais interesses das crianças

4.2.2 Interpretações articuladas entre as temáticas das exposições e o conhecimento de mundo

4.3 Professores de educação infantil e práticas educativas nos museus e centros culturais

4.3.1 Os professores de educação infantil e a prática de frequentar museus

4.3.2 A percepção dos professores sobre a relação entre museus e crianças

4.3.3 As relações estabelecidas pelos professores no momento da visita

4.4 Articulações entre os museus e a educação infantil

4.4.1 Obstáculos na relação entre museus e educação infantil

4.4.2 Mudanças necessárias para a melhoria da relação museus e educação infantil

4.4.3 Ações que contribuem para a articulação entre museus e Educação Infantil

Considerações finais

Referências bibliográficas

Apêndices

Apêndice 1 - Museus e centros culturais da cidade do Rio de Janeiro que possuíam programação específica para Educação Infantil em 2015

Apêndice 2 -Roteiro de entrevista com professores

Apêndice 3 - Roteiro de entrevista com mediadores

Apêndice 4 - Roteiro de entrevista com coordenadores dos setores educativos

Apêndice 5 - Roteiro de observação 


\section{Lista de Figuras}

Figura 1: Distribuição dos museus participantes da pesquisa e alunos matriculados no segmento de Educação Infantil da SME-RJ

Figura 2: Exposição "Aedes: Que mosquito é esse? na Casa da Ciência da UFRJ

Figura 3: Exposição "Portinari e o Meio Ambiente" na 102 Casa da Ciência da UFRJ

Figura 4: Imagens da Casa da Ciência da UFRJ (QR code 1)

Figura 5: Exposição Museu Casa de Rui Barbosa / Sala 105 de Música

Figura 6: Imagens do Museu Casa de Rui Barbosa (QR code 2 )

Figura 7: Exposição "Dja Guata Porã" no Museu de Arte do Rio

Figura 8: Exposição "Feito Poeira ao Vento" no Museu de 109 Arte do Rio

Figura 9: Exposição "Dentro" no Museu de Arte do Rio

Figura 10: Imagens do Museu de Arte do Rio (QR code 3) 


\section{Lista de Tabelas, Quadros e Gráficos}

Tabela 1: Distribuição Quantitativa dos municípios do estado do

Rio de Janeiro que possuem museus

Tabela 2:Municípios do estado do Rio de Janeiro com maior número de museus

Tabela 3:Quantitativo da pesquisa de campo

83

Quadro 1: Levantamento bibliográfico

Quadro 2: Triangulação dos recursos metodológicos

82

Quadro 3: Perfil dos entrevistados

83

Quadro 4: Museus e centros culturais da cidade do Rio de Janeiro que possuíam programação específica para Educação Infantil em 2015

Gráfico 1: Número de museus da cidade do Rio de Janeiro em função da frequência do público infantil por faixa etária

Gráfico 2: Número de museus da cidade do Rio de Janeiro por tipo de acompanhante do público infantil

Gráfico 3: Número de museus da cidade do Rio de Janeiro que possuem ou não programação específica paras as escolas de Educação Infantil

Gráfico 4: Número de museus da cidade do Rio de Janeiro que não possuem programação específica para o público de Educação Infantil por tipologia de museu

Gráfico 5: Número de museus da cidade do Rio de Janeiro que possuem programação específica para o público de Educação Infantil por tipologia de museu

Gráfico 6: Número de museus da cidade do Rio de Janeiro que possuem programação específica para o público de Educação Infantil por tipo de atividade oferecida para crianças de 0 a 3 e de 4 a 6 anos

Gráfico 7: Número de museus da cidade do Rio de Janeiro que possuem programação específica para o público de Educação Infantil por tipo de espaço onde são realizadas as atividades

Gráfico 8: Número de museus da cidade do Rio de Janeiro por formação dos profissionais que realizam as atividades com as escolas de Educação Infantil 
Gráfico 9: Número de museus da cidade do Rio de Janeiro segundo a necessidade de mudanças para melhorar a recepção ao público infantil 


\section{Lista de Siglas}

GEPEMCI - Grupo de Pesquisa em Educação, Museus, Cultura e Infância

E.I - Educação Infantil

UFRJ - Universidade Federal do Rio de Janeiro

UERJ - Universidade do Estado do Rio de Janeiro

UNIRIO - Universidade Federal do Estado do Rio de Janeiro

BDTD - Biblioteca Digital Brasileira de Teses e Dissertações

CAPES - Coordenação de Aperfeiçoamento de Pessoal de Nível Superior

ANPED - Associação Nacional de Pós-Graduação em Educação

ECA - Estatuto da Criança e do Adolescente

LDB - Lei de Diretrizes e Bases da Educação Nacional

RCENI - Referencial Curricular Nacional para a Educação Infantil

DCNEI - Diretrizes Curriculares Nacionais para a Educação Infantil

BNCC - Base Nacional Curricular Comum

IBRAM - Instituto Brasileiro de Museus

SEC-RJ - Secretaria de Estado de Cultura do Rio de Janeiro

BIMM - Biblioteca Infanto-Juvenil Maria Mazzetti

CLT - Consolidação das Leis do Trabalho

VLT - Veículo Leve sobre Trilhos

SME-RJ - Secretaria Municipal de Educação do Rio de Janeiro

REM-RJ - Rede de Educadores em Museus do Rio de Janeiro 


\section{1 \\ Introdução}

A pesquisa de doutorado aqui apresentada está ligada a uma trajetória acadêmica e pessoal em que as relações entre educação, infância e museus se encontram entrelaçadas.

Quando criança, inúmeras visitas aos museus não foram agradáveis lentas, longas, silenciosas e uma sensação de que não havia o que fazer - outras foram boas e ficaram na memória, como, por exemplo, a ida ao Museu Imperial, na cidade de Petrópolis (RJ), onde deslizar com pantufas foi a descoberta de uma nova brincadeira. Mais tarde, ao cursar a graduação em Pedagogia na Universidade do Estado do Rio de Janeiro (UERJ), novamente a relação com os espaços museológicos ressurgiu através da disciplina "Pesquisa e Prática Pedagógica - Educação Patrimonial na Cidade do Rio de Janeiro". Eram frequentes as visitas aos espaços culturais, desta vez, com o intuito de conhecer suas possibilidades educativas. Concluí a graduação realizando o trabalho monográfico intitulado "Educação e Patrimônio: a importância do fazer pedagógico nos museus", onde investiguei a atuação de pedagogos nos setores educativos. No desenvolvimento do estudo, pude dialogar diretamente com os educadores desses espaços, indagando suas ações, dificuldades e anseios. Desde então, surgiram inúmeras inquietações quanto aos aspectos educativos nos museus.

Terminada a graduação na área de Educação, considerei importante cursar o mestrado em Museologia e Patrimônio na Universidade Federal do Estado do Rio de Janeiro (UNIRIO) para adquirir conhecimentos do campo Museal e ampliar o diálogo acadêmico entre as áreas. Também atuando como docente no segmento de Educação Infantil (E.I), na dissertação de mestrado, desenvolvi uma investigação acerca da relação entre os museus de arte e as crianças da Educação Infantil.

Após a conclusão do mestrado e com o ingresso no Grupo de Pesquisa em Educação, Museus, Cultura e Infância (GEPEMCI/PUC-Rio) ${ }^{1}$, inúmeras possibilidades de pesquisa sobre os aspectos educativos para o público infantil

\footnotetext{
${ }^{1}$ Grupo de Pesquisa o qual fui convidada a participar no ano de 2013 tendo a oportunidade de dialogar e aprofundar os temas da pesquisa iniciada no mestrado e participo até o presente momento.
} 
nos museus continuaram sendo vislumbradas. Um dos apontamentos da banca avaliadora, na defesa da dissertação, foi a expansão da pesquisa sobre crianças nos espaços museológicos para além da tipologia de arte; ou seja, seria oportuno investigar as relações que podem ser estabelecidas entre público infantil e museus de diferentes temáticas.

Contudo, compreendi que investigar mais profundamente as experiências educativas dos museus e centros culturais com o público escolar de Educação Infantil implica estar atento aos diversos elementos envolvidos nessa relação: o espaço, o acervo, o trabalho dos mediadores e dos professores e (não somente) as crianças.

Da parte dos museus, era preciso saber se ofereciam programação específica para as crianças da Educação Infantil, conhecer a estrutura dos setores educativos das instituições que recebem esse público, a formação dos profissionais que elaboram e realizam as ações, a relação estabelecida com as crianças, as atividades desenvolvidas, as metodologias implementadas, observar a utilização dos espaços expositivos com as crianças e saber se a instituição oferecia algum tipo de formação aos profissionais para pensar o público infantil em seus espaços.

Investigar como essa relação se dá para as crianças também era um aspecto importante, ou seja, perceber, de modo geral, como reagiam à experiência de visitar museus com a escola, descobrir quais eram suas expectativas, o que diziam, como se comportavam, o que despertava maior interesse, quais conhecimentos e interpretações conseguiam articular.

Outro aspecto a ser estudado era a forma como os professores participam dessa relação: averiguar se os professores que visitam os museus com suas turmas possuíam o hábito de frequentar museus, se costumavam levar suas turmas de E.I a museus e centros culturais, se tinham preferência por algum tipo de museu, se essa prática foi estimulada na formação, saber o que pretendiam proporcionar às crianças com as visitas, se consideravam a visita realizada relevante e observar como se relacionavam com o conteúdo das exposições/com os mediadores/com as crianças.

\section{1 .}

Questões, objetivos e metodologia

Diante de tantas possibilidades, comecei a desenvolver esta pesquisa de doutorado que foi impulsionada a partir do recorte sobre as seguintes questões: 
i) Como os museus e centros culturais recebem o público de Educação Infantil?

ii) Qual é a relação estabelecida pelos museus com o público infantil?

iii) Como as crianças reagem à experiência museal de diferentes temáticas?

iv) Como os professores de E.I se relacionam com as práticas educativas dos museus e centros culturais?

v) Existe articulação entre museus e escolas de Educação Infantil?

Observar e tentar compreender como todos esses elementos interagem entre si, foi a motivação desta pesquisa de doutorado. Busquei investigar essa relação em sua integralidade, considerando os diferentes agentes nela envolvidos: crianças, professores e educadores dos museus. Para tanto, foi priorizada a investigação dessa relação em museus de tipologias distintas, localizados na cidade do Rio de Janeiro.

Desta forma, a pesquisa teve como objetivo geral conhecer a relação entre o público de Educação Infantil e museus de diferentes tipologias da cidade do Rio de Janeiro, buscando compreender quais aspectos possibilitam e dificultam esse encontro. E como objetivos específicos:

i) Analisar o modo como as instituições museais se preparam (espaço/equipe/ações) para receber crianças em visitas escolares;

ii) Identificar a relação estabelecida pelos museus com o público infantil;

iii) Perceber como as crianças reagem à experiência museal - expectativas, formas como se expressam, conhecimentos e interpretações que conseguem articular;

iv) Conhecer as relações estabelecidas pelos professores de E.I que impulsiona a prática de levar suas turmas aos museus e centros culturais;

v) Verificar se existem aspectos que dificultam ou facilitam a relação entre museus e escolas de Educação Infantil.

Considerando os objetivos, a pesquisa foi desenvolvida por meio da abordagem qualitativa, que se mostrou a mais adequada por ser um meio de produção de conhecimento que não busca mensurar e medir, mas sim compreender e buscar explicações para valores e significados de um meio social. Além dos estudos teóricos acerca da infância, educação e museus, foi realizada a observação de campo em três instituições museológicas: Museu de Arte do Rio, Casa da Ciência da Universidade Federal do Rio de Janeiro (UFRJ) e Museu Casa de Rui Barbosa.

No percurso investigativo, quatro recursos metodológicos foram utilizados: 
i) Base de Dados do GEPEMCI - para o mapeamento de todos os museus e centros culturais da cidade do Rio de Janeiro que ofereciam programação para Educação Infantil, identificação das tipologias de museu que mais e menos recebiam esse público, atividades desenvolvidas, espaços de recepção e formação dos profissionais que atuavam junto às crianças;

ii) Observação de campo - de visitas realizadas por escolas de Educação Infantil aos museus selecionados para a investigação;

(iii) Entrevistas individuais e coletivas - com os responsáveis dos setores educativos, com os mediadores e com professores;

iv) Análise documental - documentos oficiais, internos ou disponíveis na web sobre a proposta de ações oferecidas ao público de Educação Infantil nos museus investigados.

\section{2.}

\section{Levantamento bibliográfico e principais referenciais teóricos}

Tendo em vista que a proposta de investigação foi conhecer a relação entre o público de Educação Infantil e museus de diferentes tipologias da cidade do Rio de Janeiro, o trabalho de revisão de literatura da pesquisa buscou realizar o levantamento dos estudos sobre a temática a ser desenvolvida. Foi averiguada a existência de teses, dissertações e artigos publicados em periódicos conceituados, fóruns e anais de congressos nacionais reconhecidos na área de Educação.

A revisão de literatura examinou as bases da Biblioteca Digital Brasileira de Teses e Dissertações (BDTD), o Banco de Teses e Dissertações da CAPES, os artigos oriundos do GT7-Educação para crianças de 0-6 anos da Associação Nacional de Pós-Graduação em Educação (ANPED) e os estudos recentes sobre a temática publicados em livros, capítulos de livros e periódicos.

Com o resultado da busca foi possível constatar que, no Brasil, há uma lacuna nas pesquisas que se debrucem sobre a relação entre museus e o público escolar de Educação Infantil. A partir dos descritores Educação Infantil-museu(s), criança pequena-museu(s), infância(s)-museu(s), público infantil-museu(s) foram encontrados cinco estudos que, de fato, tratam sobre o tema (quadro 1):

Quadro 1: Levantamento Bibliográfico

\begin{tabular}{|c|l|l|}
\hline \multicolumn{1}{|c|}{ AUTOR } & \multicolumn{1}{|c|}{ PESQUISA } & \multicolumn{1}{c|}{ ASSUNTO } \\
\hline Moura (2005) & $\begin{array}{l}\text { Dissertação - "Arte e } \\
\text { Infância: Um estudo das } \\
\text { interações entre crianças, } \\
\text { adultos e obras de arte em } \\
\text { museu" }\end{array}$ & $\begin{array}{l}\text { Pesquisa sobre as interaçóes do público } \\
\text { com as obras no espaço do Museu de Arte } \\
\text { diferentes do Río de Janeiro. Em meio aos } \\
\text { os três grupos escoz uma reflexão sobre } \\
\text { Infantil que visitaram o Museu. }\end{array}$ \\
\hline
\end{tabular}




\begin{tabular}{|c|c|c|}
\hline AUTOR & PESQUISA & ASSUNTO \\
\hline $\begin{array}{l}\text { Santos } \\
(2010)\end{array}$ & $\begin{array}{l}\text { Dissertação - "Museu e } \\
\text { Escola: uma experiência } \\
\text { de mediação entre } \\
\text { crianças de } \\
\text { Infantil educação } \\
\text { museológico" o espaço }\end{array}$ & $\begin{array}{l}\text { Pesquisa-intervenção que propôs } \\
\text { estratégias mediadoras para crianças do } \\
\text { Jardim II em um museu histórico e pode } \\
\text { constatar as diferentes leituras realizadas } \\
\text { pelas crianças sobre os objetos do museu } \\
\text { (leituras lúdicas, leituras museológicas e } \\
\text { leituras históricas). }\end{array}$ \\
\hline Gabre (2011) & $\begin{array}{l}\text { Dissertação }- \text { "Mediação } \\
\text { Cultural para a pequena } \\
\text { infância: um projeto } \\
\text { educativo no } \\
\text { Guido Viaro". }\end{array}$ & $\begin{array}{l}\text { Pesquisa intervenção que contou com a } \\
\text { elaboração de um projeto educativo de } \\
\text { mediação cultural com a participação dos } \\
\text { educadores do Museu e de Educação } \\
\text { Infantil de Curitiba. }\end{array}$ \\
\hline Lopes (2014) & 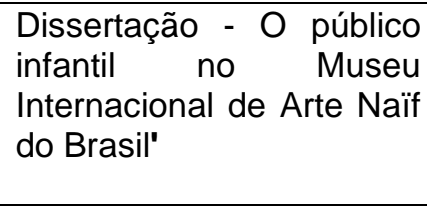 & $\begin{array}{l}\text { Oportunidade que tive de desenvolver } \\
\text { uma pesquisa acerca das relações entre } \\
\text { infância, arte e educação em museus } \\
\text { observando visitas de escolas de E.I no } \\
\text { Museu investigado }\end{array}$ \\
\hline Gabre (2016) & $\begin{array}{l}\text { Tese - "Para habitar o } \\
\text { museu com o público } \\
\text { infantil: Uma proposta de } \\
\text { formação colaborativa } \\
\text { entre professores da } \\
\text { infância e profissionais do } \\
\text { Museu Municipal de Artes } \\
\text { de Curitiba" }\end{array}$ & $\begin{array}{l}\text { Pesquisa sobre o contexto de formação } \\
\text { continuada entre professores da } \\
\text { Educação Infantil e profissionais do Museu } \\
\text { no que concerne ao trabalho que envolve } \\
\text { a visita da criança pequena ao museu de } \\
\text { arte. }\end{array}$ \\
\hline
\end{tabular}

Fonte: Elaboração própria

Analisando as pesquisas supracitadas, constata-se que a maior parte dos estudos foi realizada em instituições de arte, não sendo possível compreender a relação educativa que pode ser estabelecida entre esse público e os museus de diferentes temáticas/tipologias. A dissertação e a tese de Gabre (2011; 2016), com contribuições teóricas sobre o tema, também tomam como sujeito de pesquisa os educadores (professores de E.I e educadores do museu) e as crianças não participam, diretamente, da investigação.

Um estudo realizado por Cury (2015), que apresenta o estado da arte sobre as pesquisas acadêmicas de recepção de público em museus no Brasil, produzidas no período de 2004 a 2014, revelou que ao longo de todos esses anos foram publicados 44 trabalhos sobre o tema. Dentre as pesquisas realizadas, apenas três referem-se ao estudo do público infantil: "O que as crianças falam sobre o museu..." - dissertação de mestrado de Célia Flores (2007) realizada com crianças do ensino fundamental, "As crianças nos museus de ciências: análise da exposição Mundo da Criança do Museu de Ciências e Tecnologia da PUCRS" dissertação de mestrado de Cynthia Iszlaji (2012) e "O público infantil no Museu Internacional de Arte Naïf do Brasil" - dissertação de mestrado que tive a oportunidade de desenvolver no ano de 2014. 
Contudo, alguns pesquisadores nacionais ${ }^{2}$ que se dedicaram a discutir a relação entre crianças e museus, publicando seus estudos em livros e periódicos, colaboram na tentativa de compreender alguns aspectos que vem se delineando nessa relação. Trabalhos da literatura internacional ${ }^{3}$ também contribuem para 0 debate acerca da potência e dos obstáculos que são frequentemente encontrados na relação entre museu e público infantil.

Além dessa literatura específica sobre a temática, as perspectivas teóricas da área da Estética, Infância e Museologia também contribuíram para o constructo teórico da pesquisa.

O debate concernente à formação do indivíduo, pautada nas experiências em meio à cultura e às manifestações culturais, teve como alicerce os estudos de Benjamin (2012), Dewey (2002; 1979) e Vigotski (2009).

A discussão sobre como a estética, no contexto contemporâneo, disponibiliza compreensões que favorecem a formação humana e sensível teve como principais referências Dewey (2010), Camargo (2011), Meira (2011), Vigotski (1998; 2003) e Hermann (2010).

A reflexão acerca da concepção de infância e da dimensão estética do conhecimento na Educação Infantil foi pautada nos trabalhos de Kramer (1996; 1998; 2000; 2005); Vecchi (2006); Kuhlmann Jr. (2010); Benjamin (2017); Dewey (2002), Vigotski (1998; 2009), Martins, Picosque e Guerra (1998).

O debate sobre a função social e a dimensão educativa dos museus, ao longo da história, e suas implicações atuais no trabalho desenvolvido junto aos diferentes públicos, foi alicerçado nas investigações de Poulot (2013), Mortara (2018), Martins (2011), Machado (2005), Köptcke (2003), Valente (2009), Cury (2007), Cazelli (2010) e Carvalho (2016).

\section{3.}

\section{Estrutura da tese}

Neste primeiro capítulo introdutório, são apresentados os percursos acadêmicos e de vida que levaram à investigação proposta nesta pesquisa, as questões motrizes, os objetivos (geral e específicos), uma explicitação breve da natureza metodológica e das principais ferramentas utilizadas, o levantamento bibliográfico sobre o tema, os principais referenciais utilizados no constructo teórico e a forma como a tese está estruturada.

\footnotetext{
2 Carvalho (2013; 2016); Oliveira (2011); Kramer e Carvalho (2012); Reddig (2007), Moura (2011); Leite (2005; 2011); Carvalho e Porto (2013); Carvalho, Lopes e Resinentti (2017).

${ }^{3}$ Wagensberg (2008); Pol e Asensio (2006); Shaffer (2015); Fallon e Chavepeyer (2013).
} 
O segundo capítulo é destinado à reflexão teórica dos principais conceitos abordados na pesquisa: experiência, estética, infância e museus. Buscando tecer o diálogo entre os diferentes campos, a discussão foi organizada em três subcapítulos. No primeiro momento, é discutido o conceito de experiência, as especificidades da experiência estética e sua importância enquanto dimensão educativa na formação humana. O segundo momento é dedicado à reflexão sobre o entendimento histórico acerca do conceito de infância (e sua implicação na paulatina garantia de direitos), e, partindo do pressuposto que a dimensão estética permeia as formas de apreensão do mundo pela criança, é analisado como a Educação Infantil, no Brasil, se relaciona com as experiências estéticas e com o uso dos equipamentos culturais por meio da análise de seus documentos orientadores. No terceiro, e último, subcapítulo, a partir de uma breve retrospectiva acerca da função social dos museus, é discutida a dimensão estética do conhecimento que permeia esses espaços e as relações profícuas que podem ser estabelecidas com o público infantil.

O terceiro capítulo, que investiga as ações oferecidas pelos museus da cidade do Rio de Janeiro para o público infantil, selecionados para a realização desta investigação, foi dividido em seis subcapítulos. É iniciado com a exposição detalhada da metodologia de pesquisa e, em seguida, há um mapeamento geral sobre as condições da recepção ao público infantil nos museus e centros culturais da cidade. No terceiro momento, são apresentados os museus que participaram da pesquisa de campo: missão, acervo, equipe, estrutura dos setores educativos, exposições em cartaz. No quarto momento, o objetivo foi evidenciar as especificidades dos espaços expositivos na recepção às crianças no que concerne às possibilidades de mobilidade, autonomia e brincadeira. Posteriormente, foram analisadas as ações educativas desenvolvidas nos museus investigados: se possuíam projetos desenvolvidos especificamente para o público de Educação Infantil, o que pretendiam provocar nas crianças com o trabalho desenvolvido, metodologias, formas de avaliação e reformulação das atividades. No sexto e último subcapítulo, é discutida a formação que os mediadores desses espaços recebem para atuar junto ao público infantil.

O quarto capítulo trata dos aspectos da interação que ocorrem entre os diferentes agentes da visita: as crianças, os museus (exposição e mediadores) e os professores. Para tanto, foi necessária sua organização em quatro subcapítulos. Primeiro é apresentada a relação estabelecida pelos museus com o público infantil - o que os profissionais dos museus falam sobre esse segmento e as constatações observadas na prática. Posteriormente, é analisada a relação que 
as crianças estabelecem com a experiência museal: expectativas, reações, expressões, interesses e a articulação que fazem entre o conteúdo das exposições e seus conhecimentos de mundo. No terceiro subcapítulo é abordado como os professores de Educação Infantil se relacionam com as práticas educativas nos museus e centros culturais e suas percepções sobre a relação entre museus e crianças. No quarto e último subcapítulo são explicitadas as articulações entre os museus e a Educação Infantil que puderam ser percebidas ao longo da investigação - obstáculos encontrados, necessidades de mudança identificadas e ações que contribuem para ampliar essa relação.

Por último são apresentadas as considerações finais da pesquisa, cujo resultado apontou que para proporcionar experiências estéticas para o público infantil nos museus tem sido necessário enfrentar alguns obstáculos teóricos, financeiros e estruturais. Além disso, ainda são poucas as pesquisas que se dedicam a estudar o tema. De toda forma, o estudo teórico acerca da experiência, estética, infância e museus, aliado à pesquisa de campo, mostrou que a experiência estética nos espaços museais se constitui na interação com as manifestações, registros e celebração das diferentes formas de viver e estar no mundo. Nesse sentido, os museus podem ser compreendidos enquanto meio experimental e criativo - profícuo para promover experiências estéticas às crianças a partir da interação com a cultura material. Para tanto, é necessário que se amplie a troca de saberes entre museus, escola e universidade com o intuito de se reduzir a lacuna entre os estudos sobre a infância e as práticas educativas com as crianças nos espaços culturais. Por fim, espera-se que a pesquisa aqui apresentada contribua para a reflexão sobre a práxis educativa dos profissionais da escola e do museu com o intuito de possibilitar às crianças que frequentam a Educação Infantil uma formação alicerçada em experiências imbuídas de significado ético, político e estético. 


\section{2 \\ Experiência estética, infância e museu}

\section{1.}

\section{Relações entre experiência, estética e conhecimento}

Investigar a relação entre Educação Infantil e museus implica reconhecer que seu aspecto educativo não pode ser examinado desvinculado da experiência. O conteúdo dos museus é a experiência acumulada em saberes humanos e a relação estabelecida (quando significativa) entre os diferentes agentes que participam de uma visita escolar (crianças, professores e mediadores) também constitui uma experiência. Reconheço que as experiências são únicas e não há como mensurar o que é apreendido por cada um. Entretanto, é válido investigar como crianças, adultos e museus e relacionam de forma a construir novos significados e leituras de mundo. Para tanto, alguns conceitos teóricos basilares precisaram ser elucidados na tentativa de compreender o que foi possível observar com os achados atuais dessa relação. Desta forma, esse capítulo se propõe a discutir teoricamente o entendimento acerca da experiência, da infância e dos museus entrelaçados pela dimensão estética do conhecimento. ${ }^{4}$

Para Dewey (2010), a experiência ocorre continuamente entre os seres humanos porque reside na interação do indivíduo com o meio - está envolvida no processo interativo de viver. A experiência consiste na acentuação dessa vitalidade, "em vez de significar um encerrar-se em sentimentos e sensações privados, significa uma troca ativa e alerta com o mundo; em seu auge, significa uma interpenetração completa entre o eu e o mundo dos objetos e acontecimentos" (DEWEY, 2010, p.83).

O autor considera a experiência instantânea uma impossibilidade, tanto biológica quanto psicológica, visto que a experiência é um produto da interação continua e cumulativa de um processo orgânico do indivíduo com o mundo. Sob essa perspectiva, o ser humano traz em si forças que desempenham um papel nessa interação: age, porém, também é submetido ao que vem de fora.

\footnotetext{
${ }^{4}$ A discussão teórica elucidada neste estudo foi alicerçada nas teorias de Dewey, Benjamin e Vigotski que dialogam no que tange à importância da interação entre o sujeito e o ambiente. No entanto, é importante reconhecer que esses autores possuem distinções teóricas na forma como concebem o processo de constituição da experiência que não será foco de análise nesse estudo.
} 
Dewey (1979) pontua que toda experiência, considerada genuína, possui um lado ativo, que modifica as condições objetivas (no meio e nos indivíduos) em que as experiências se passam e elenca dois de seus princípios fundamentais: continuidade e interação. Estes dois princípios não se separam, encontram-se interligados e unidos.

O princípio da interação atribui direitos iguais a ambos os fatores da experiência: as condições objetivas do meio e as condições internas do indivíduo. Tomadas em conjunto, ou em sua interação, essas condições constituem o que o autor chama de situação. A afirmação de que os indivíduos vivem em um mundo significa que vivem uma série de situações. O princípio da interação compreende, portanto, a relação permanente entre indivíduo, objetos e outras pessoas. Uma experiência é genuína quando ocorre uma ligação entre um indivíduo e seu meioformado por pessoas, atitudes, assuntos - constituindo uma situação.

Nesse processo, diferentes situações se sucedem, mas, devido ao princípio da continuidade, algo é levado de uma experiência à outra. Quando o indivíduo passa de uma situação para outra, seu mundo se expande ou se contrai. O que aprendeu como conhecimento obtido a partir de uma experiência em uma situação torna-se instrumento para compreender e lidar efetivamente com situações posteriores.

O autor revela ainda que a qualidade de qualquer experiência possui dois aspectos fundamentais: i) o imediato - de ser agradável ou desagradável; ii) mediato - de influenciar experiências posteriores. Em sua compreensão, nenhuma experiência vive ou morre para si mesma, todas as experiências vivem e se prolongam em experiências que se sucedem. A qualidade da experiência está diretamente relacionada ao princípio da continuidade e pode atuar de modo bem diverso. A qualidade da experiência sob o princípio da continuidade, pode operar de modo a imobilizar a pessoa em um baixo nível de desenvolvimento limitando sua capacidade de crescimento. Quando uma experiência desperta curiosidade, fortalece iniciativas e suscita desejos e propósitos suficientemente intensos, pode-se conduzir o indivíduo aonde for preciso no futuro. "A continuidade funciona de modo bem diverso e cada experiência é uma força em marcha" (DEWEY, 1975, p.25).

Sobre o processo constitutivo da experiência, produzido em meio à continuidade e interação, as perspectivas teóricas de Dewey (1979;2010), Benjamin (2012) e Vigotski (2009), no que é concernente ao processo de formação do sujeito, evidenciam o papel da tradição. 
Dewey $(1979 ; 2010)$ afirma que a experiência não ocorre apenas dentro da pessoa. Pontua a importância do meio, que é tanto humano quanto físico, trazendo à luz a importância do material da tradição e das instituições. Para o autor, cada tradição, por si só, é um hábito organizado de visão e de métodos para ordenar e transmitir o material de determinado grupo em determinada época. Logo, qualquer trabalho pode ser relativamente fraco quando não é perpassado por uma experiência ampla e variada das tradições em que o indivíduo opera.

Em uma palavra, vivemos do nascimento até a morte em um mundo de pessoas e cousas que, em larga medida, é o que é devido ao que se fez e ao que nos foi transmitido de atividades humanas anteriores. Quando se ignora este fato, trata-se a experiência como algo que ocorre exclusivamente dentro do corpo e da mente das pessoas. Dispensável repetir que a experiência não sucede no vácuo. Há fontes fora do indivíduo que a fazem surgir (DEWEY, 1979, p.31).

Benjamin (2012) também aborda o aspecto social da tradição e da continuidade na experiência que sempre fora comunicada pelos mais velhos aos mais jovens "de forma concisa, com a autoridade da velhice, em provérbios; de forma prolixa, com a sua loquacidade, em histórias; às vezes como narrativas de países longínquos, diante da lareira, contada a filhos e a netos"(BENJAMIN, 2012, p. 42). Segundo o autor, os estilos e visões de mundo, que constituem todo o patrimônio cultural - legado da humanidade e produto da experiência- são transmitidos às gerações futuras, principalmente, por meio das narrativas.

Para Benjamin (2012), a verdadeira natureza da narrativa traz uma utilidade que, por vezes, consiste em um ensinamento moral, uma sugestão prática, um provérbio ou uma norma de vida. Parte da arte narrativa está em, ao comunicar uma história, evitar explicações. A partir dessa experiência, o leitor/ouvinte é livre para interpretar a história como quiser, e, desta forma, o episódio narrado atinge a amplitude de convidar o indivíduo a refletir sobre o sentido da vida. Por sua vez, o narrador, sujeito mais experiente, é aquele que sabe dar conselhos ao ouvinte e "o conselho tecido na substância da vida vivida tem um nome: sabedoria" (BENJAMIN, 2012, p. 76).

Vigotski (2009), elucubrando sobre a formação humana e seu potencial criativo, igualmente destaca a relevância da experiência coletiva socialmente adquirida. O sujeito tem a ampliação de sua experiência e de sua capacidade criativa porque "tendo por base a narração ou a descrição de outrem, ele pode imaginar o que não viu, o que não vivenciou diretamente em sua experiência pessoal" (VIGOTSKI, 2009, p.25).

Para o autor, as atividades especificamente humanas são conscientemente orientadas e só se tornam possíveis no âmbito das relações sociais, mediada por 
instrumentos e signos. Ao refletir sobre a importância da experiência prévia (no nível pessoal) no processo de formação do indivíduo, enfatiza que ela é incorporada pela experiência social, histórica e coletiva, sendo vista como uma condição fundamental para o potencial criativo dos seres humanos.

A atividade criativa é entendida pelo autor como toda aquela em que algo novo é criado, independente se seu fruto é a criação de um objeto, sentimento, imagens ou ações. Em cada etapa da vida, existem atividades criadoras que são constituídas em um processo lento e gradativo que não existe de modo isolado depende de outras formas de atividade e, pincipalmente, do acúmulo de experiências. O indivíduo, portanto, não apenas conserva e reproduz experiências, também combina e reelabora, de forma criadora, elementos da experiência prévia, fazendo emergir novas situações. Qualquer invenção (grande ou pequena), antes de ser realizada e implementada na sociedade, é constituída na mente por meio de novas combinações e correlações advindas da experiência.

Dewey (2010) considera que a mente forma o "pano de fundo" no qual se projeta cada novo conhecimento adquirido pela experiência. O autor, na mesma linha de pensamento de Vigotski (2009), destaca que esse "pano de fundo" é ativo e que na projeção do novo sobre ele há, conjuntamente, um processo de assimilação, ressignificação e construção - tanto do "pano de fundo" quanto do que é absorvido. A mente é, portanto, formada pelas modificações do eu ocorridas no processo das interações com o meio.

É importante destacar que, ao tratar da aquisição do conhecimento adquirida por meio da experiência e ressaltar o lugar de destaque da mente nesse processo, o autor coloca a relação do corpo e dos órgãos dos sentidos em um patamar igualmente importante. Faz ainda uma crítica à separação desses elementos (mente, corpo e órgãos do sentido) ao avaliar que, nas experiências ocorridas com maior frequência, os diferentes sentidos não têm sido unidos para contar uma histórica comum de forma ampliada. A relação dos indivíduos com a experiência permanece superficial porque não se funde à qualidade dos sentidos que fornecem a capacidade de mergulhar abaixo da superfície na tentativa de apreender o sentido das coisas do mundo. Segundo o autor, os órgãos dos sentidos são usados para despertar a paixão, mas não para servir ao interesse do discernimento. Enfatiza que acabamos cedendo às condições de vida moderna e acelerada que forçam os sentidos a se manterem como excitações superficiais e "o prestígio vai para aqueles que usam a mente sem a participação do corpo e que agem vicariamente através do controle dos corpos e do trabalho de terceiros" (Dewey, 2010, p.87). 
A experiência é o resultado da interação entre organismo e meio que, quando plenamente realizada, é uma transformação da interação em participação e comunicação. Visto que os órgãos sensoriais, com o aparelho motor que lhes está ligado, são os meios dessa participação, sua invalidação é efeito e causa de um empobrecimento da experiência de vida (DEWEY, 2010, p. 89).

Nesse sentido, o autor alerta que existem condições gerais sem as quais a experiência não é possível, "a condição fundamental é a relação vivida entre o fazer e o sofrer, à medida em que organismo e meio interagem"(Dewey, 2010, p.379).Uma experiência não é apenas uma alternância do fazer e do ficar sujeito a algo, consiste nas duas coisas relacionadas. "Pôr a mão no fogo não é, necessariamente, ter uma experiência. A ação e sua consequência devem estar unidas na percepção" (Dewey, 2010, p.122). É preciso criar o equilíbrio entre o agir e o receber para que seja fixado na mente o conhecimento. Para o autor, é a percepção da relação entre o que é feito e o que é suportado que constitui o trabalho da inteligência. Graças à relação entre o que é feito e o que é sofrido, há na percepção um sentido imediato das coisas como compatíveis ou incompatíveis, reforçadoras ou indiferentes.

Desta forma, toda vez que se passa por uma experiência, ocorre uma modificação do sujeito. Essa modificação vai além da aquisição de uma facilidade ou habilidade maiores, é formada por atitudes e interesses que constituem um repertório de significados de coisas feitas e sofridas. Esses significados, acumulados e agrupados, compõem o capital com o qual se observa, cuida, atenta e age diante do mundo. Para Dewey (2010), na medida em que o desenvolvimento de uma experiência é realizado em sua integralidade e resulta na tomada de consciência pelo indivíduo, essa experiência passa a ter uma natureza predominantemente estética.

\subsection{1.}

\section{Especificidade da experiência estética}

Para iniciar uma reflexão sobre a relação entre experiência estética e a formação dos sujeitos, cabe esclarecer que, historicamente, o termo "estética" se prestou a distintas significações e é importante estabelecer o significado adotado nesta pesquisa.

Introduzido no século XVIII pelo filósofo alemão Alexander Baumgarten ${ }^{5}$, o termo foi definido enquanto ciência filosófica que tinha como princípio a integração dos sentidos físicos com a intelecção, necessária à lógica para o estabelecimento

\footnotetext{
${ }^{5}$ Alexander Gottlieb Baumgarten (1714-1762): Filósofo alemão, nascido em Berlim, é considerado o criador da estética moderna. Foi professor em Frankfurt. Obras principais: Meta-física (1739), Estética acromática, inacabada (1750-1758). Ver: JAPIASSU e MARCONDES (2001).
} 
da verdade. De acordo com Camargo (2011), a Estética Moderna foi fundada levando em conta a sensibilidade (aisthesis) e a liberdade do sujeito receptor da arte e da beleza. Nesse receptor, as sensações e os sentimentos seriam especialmente aguçados pelo belo.

Estética (in. Aesthetics; fr. Esthêtique, ai.Aesthetik; it. Estética). Com esse termo designasse a ciência (filosófica) da arte e do belo. O substantivo foi introduzido por Baumgarten, por volta de 1750, num livro (Aestheticd) em que defendia a tese de que são objeto da arte as representações confusas, mas claras, isto é, sensíveis, mas "perfeitas", enquanto são objeto do conhecimento racional as representações distintas (os conceitos). Esse substantivo significa propriamente "doutrina do conhecimento sensível" (ABBAGNANO, 2007, p. 367).

Estética (gr.aisthetikós, de aisthanesthai: perceber, sentir) I. Um dos ramos tradicionais do ensino da filosofia. O termo "estética" foi criado por Baumgarten (séc. XVIII) para designar o estudo da sensação, "a ciência do belo", referindo-se à empina do gosto subjetivo, àquilo que agrada aos sentidos, mas elaborando uma ontologia do belo (JAPIASSU e MARCONDES, 2001, p.68).

Camargo (2011) esclarece que, até o século XX, a maioria das filosofias da arte manteve um distanciamento do sensorial e da percepção, apostando na arte como representação não verbal da verdade. Herman (2010) específica que apenas na década de 1980 do século XX a estética sai de um confinamento sobre o que é arte, belo e sublime, para adentrar no cotidiano, situando-se no âmbito das novas discussões da filosofia e das ciências humanas. Nesse momento, a estética passa a ser interpretada, então, como uma aproximação dos termos aisthesis e estética, na perspectiva de um novo conceito de razão que incorpora o sensível.

Para a autora, estética e aisthesis podem ser reunidas, justamente, por não se tratar de uma teoria da arte, mas de uma racionalidade que reconhece também o conhecimento pela percepção do sensível. Desta forma, o contexto em que se utiliza o termo estética no discurso contemporâneo estaria voltado para as diferentes formas pelas quais a sensibilidade atua sobre o indivíduo. Afastandose de uma teorização sobre a arte, a dimensão estética se torna objeto de consideração em todas as esferas da vida prática, e esta é a compreensão do termo adotada nesta pesquisa.

Entendendo que construímos as formas de ver e estar no mundo pela experiência (que é tangenciada pela percepção do sensível) e que a arte possui aspecto fundamental nesse processo de formação do sujeito, os estudos de Dewey (2010) e Vigotski (1998;2003) - específicos sobre a discussão da experiencia e da educação com a estética e com a arte-,dentre outros trabalhos, ajudam a esclarecer o tema. Após elucidar sobre o conceito de experiência, é importante buscar compreender como a experiência estética, provinda do 
encontro com a arte, pode afetar na formação do sujeito e contribuir para a construção de diferentes formas de perceber e de agir no mundo.

No que se refere ao entendimento acerca da experiência estética, Dewey (2010) considera que esta é a experiência em sua íntegra - libertada das forças que impedem e confundem seu desenvolvimento como experiência. É um desafio ao pensamento, pois exige evocação e organização, através da imaginação, por parte daquele que a vive. Todos os elementos que constituem o sujeito, advindos de outras experiências, se fundem na experiência estética.

O traço distintivo da experiência estética é exatamente o fato de que, nela, não existe distinção entre o eu e o objeto/meio. A experiência é estética na medida em que o organismo e o meio cooperam na constituição de uma experiência na qual ambos ficam tão plenamente integrados que desaparecem (DEWEY, 2010, p.435).

Para o autor, a experiência do ser humano é passível de uma qualidade estética, pois o mundo é uma combinação de movimento e culminação, de rupturas e reencontros. O indivíduo perde e reestabelece repetidamente o equilíbrio com o meio circundante e o momento de passagem da perturbação para a harmonia é o de vida mais intensa. Os estudos de Vigotski (1998) sobre a reação estética se alinham com a perspectiva de Dewey (2010) no que se refere a essa especificidade. Para o autor, todo comportamento humano também constitui um processo em busca de equilíbrio do indivíduo com o meio.

Quanto mais simples e elementares são nossas relações com o meio, tanto mais elementar é o transcorrer do nosso comportamento. Quanto mais complexa e delicada se torna a relação entre o organismo e o meio, tanto mais ziguezagueantes e confusos se tornam os processos de equilibração. Nunca se pode admitir que essa equilibração se realize até o fim de maneira harmoniosa e plena, sempre haverá certa vantagem da parte do meio ou do organismo (VIGOTSKI, 1998, p. 311).

Sobre a busca do equilíbrio no processo de viver, Dewey (2010) destaca que os seres humanos precisam de ordem, mas também demandam a novidade sob o viés de novas experiências. Nesse processo, a confusão é desagradável, mas o tédio também o é. O processo da vida orgânica é a variação e todo movimento da experiência que, ao se completar, retorna ao começo (carregada das bagagens da viagem) já que é uma satisfação da necessidade instigadora inicial.

De acordo com Vigotski (1998; 2003), essa necessidade instigadora inicial é decorrente do fato que as possibilidades do ser humano superam suas atividades, o organismo percebe muito mais atrações e estímulos do que pode 
realizar. Em sua relação com o mundo, o indivíduo sublima ${ }^{6}$ apenas uma parte insignificante de todas as excitações que surgem em seu sistema nervoso. A diferença entre as possibilidades e a realização é resgatada no ato de criação.

Como na natureza a parte realizada da vida representa uma parcela ínfima de toda a vida que poderia ter surgido, como cada vida que nasce deve-se a milhões de vidas que não nascem, assim, no nosso sistema nervoso, a parte da vida realizada supõe a parte menor da realmente contida em nós (...) O organismo foi colocado em certo equilíbrio com o meio, é necessário regular a balança como é necessário abrir a válvula na caldeira em que a pressão do vapor supera a resistência do seu corpo. E eis que a arte é, parece ser, o veículo adequado para atingir esse equilíbrio explosivo com o meio (VIGOTSKI, 1998, p.312).

Para o autor, desde as mais remotas épocas o significado da atividade estética foi entendido como uma catarse. Ou seja, um ato de criação que culmina em uma obra de arte é a resolução e uma liberação das paixões que torturam o sujeito. Não se trata simplesmente de lazer ou transmissão de sentimentos, é uma atividade de superação do psiquismo que não encontra vazão na vida cotiana. Nesse sentido, o efeito da arte existe e se manifesta por meio de certo esclarecimento interno, de uma eliminação dos conflitos íntimos e, portanto, da liberação de algumas forças trancadas e deslocadas.

Em um caráter dialético, a contradição, a repulsa interna, a superação, a vitória, todos são componentes necessários ao ato estético. A arte é portadora desse comportamento dialético que reconstrói a emoção e, por isso, envolve a mais complexa atividade de uma luta interna dos indivíduos que é resolvida pela catarse. Dewey (2010) descreve essa sensação, característica da experiência estética, da seguinte forma:

O que distingue uma experiência como estética é a conversão da resistência e das tensões, de excitações que em si são tentações para a digressão em um movimento em direção a um desfecho inclusivo e gratificante. Vivenciar a experiência, como respirar, é um ritmo de absorções e expulsões (DEWEY, 2010, p. 139).

Desta forma, é possível compreender que, para os autores, o principal aspecto da estética na experiência consiste no fato de as emoções serem submetidas à certa descarga, a sua destruição e transformação em contrários, ou seja, à complexa transformação de sentimentos que resultam em uma experiência modificadora do indivíduo. Nesse sentido, não é por acaso que, historicamente, a arte tem sido considerada como um meio e um recurso de educação.

Para os autores, a relação do seres humanos com o sensível - criada, expressada e sentida na forma de arte ou objeto artístico- é, portanto, essa descarga indispensável de energia em um procedimento complexo de equilíbrio

\footnotetext{
6 Transformação dos tipos inferiores de energia psíquica não-consumidos e que não encontram
} saída na atividade normal do organismo em tipos superiores de energia (VIGOTSKI, 2003, p. 231). 
do individuo com o meio. Consideram que é uma relação que estimula o processo criador, distintivo dos seres humanos, tanto para quem cria a arte (o artista) como para quem a recebe (o público). A refundição das emoções na experiência estética realiza-se por força de um sentimento social que foi objetivado, levado para fora do sujeito, materializado e fixado nos objetos externos, que se tornaram instrumento e patrimônio da humanidade.

Dewey (2010) critica que muitas vezes a palavra "estético" é relacionada ao sentido estrito de experiência como apreciação e deleite. Essa compreensão, geralmente, é mais empregada em relação ao ponto de vista do consumidor do que o do produtor. Entretanto, para o autor, a relação entre o agir e o ficar sujeito a algo, implicada na experiência estética, indica que a distinção entre o estético e o artístico não pode ser levada a ponto de se tornar uma separação. A perfeição de uma obra de arte ou de um objeto estético não pode ser medida em termos da execução, pois implica também o caráter ativo daqueles que percebem e desfrutam do produto executado.

Dewey (2010), apesar de considerar que a fase estética da experiência é receptiva, pois envolve uma rendição, salienta que essa entrega só é possível através de uma atividade controlada (o que não impede de ser intensa) do indivíduo. Portanto, há também a ação do sujeito, que o autor define como percepção.

\begin{abstract}
Para nos impregnarmos de uma matéria, primeiro temos de mergulhar nela. Quando somos apenas passivos diante de uma cena, ela nos domina e, por falta de atividade de resposta, não percebemos aquilo que nos pressiona. Temos de reunir energia e colocá-la em um ponto receptivo para absorver (...). Em um sentido simples, os objetos podem ser "vistos". Podem ser olhados, possivelmente reconhecidos, e ter os nomes certos ligados a eles. Mas, por falta de uma interação contínua entre o organismo total e os objetos, estes não são percebidos, decerto não esteticamente (...). Sua apreciação é uma mescla de retalhos de saber (DEWEY, 2010, p.136137).
\end{abstract}

Nesse sentido, a percepção estética é a percepção plena e de seu correlato (seja um objeto ou um evento) que, de modo algum, pode ocorrer fora de um processo que se desenvolva com o tempo. Dewey (2010) considera que existe uma concepção errônea de que a experiência estética estaria ligada a uma questão de imediaticidade da percepção. Admite que existem reconhecimentos, praticamente instantâneos, que só ocorrem devido a uma sucessão de experiências pregressas que fazem o eu se especializar em certas direções. Desta forma, julga que a identificação instantânea é apenas o começo da percepção estética.

Vigotski (1998) também salienta o caráter ativo da experiência estética. Para o autor, a natureza dessa experiência envolve uma atividade construtiva complexa 
de todos os envolvidos, pois o sentimento expresso em técnica não consegue, sozinho, produzir uma obra. Para o artista é necessário o ato criador de superação desse sentimento, da sua solução, da vitória sobre ele. Para quem percebe a arte (o público) também é envolvido o ato de criação, porque nessa percepção não basta simplesmente vivenciar com sinceridade o sentimento que dominou o artista, não basta entender a estrutura da obra, é necessário ainda superar criativamente o seu próprio sentimento, encontrar a sua catarse, e só então o efeito da arte se manifesta em sua plenitude.

Todo o conteúdo e o sentimento ligados a um objeto de arte não estão nele, mas são aportados por nós. E como se introduzíssemos o sentimento das imagens da arte, e o próprio processo de percepção é chamado pelos psicólogos de "empatia". Essa complexa atividade de empatia se reduz, em essência, a renovação de uma série de reações internas, a união que as coordena e a uma certa reelaboração criativa do objeto próximo de nós. Essa função constitui a atividade estética básica que, por sua natureza, é uma atividade do organismo que reage ao estímulo externo (VIGOTSKI, 2003, p. 230).

Destaca, ainda, seu caráter social, pois considera que o efeito de uma experiência estética é mais complexo e diverso do que o simples lazer ou contágio/transmissão de sentimento. Para Vigotski (1998), a vida concentrada no sensível não influencia apenas nos sentimentos, pode influenciar igualmente nas vontades e ações dos indivíduos. As relações entre arte e vida são complexas, mas segundo o autor, a reação estética resultante da experiência com a arte decorre do aspecto que ela não é apenas uma descarga no vazio, possui efeito social.

\footnotetext{
A arte é o social em nós, e, se o seu efeito se processa em um indivíduo isolado, isto não significa, de maneira nenhuma, que as suas raízes e essências sejam individuais (...). O social existe até onde há apenas um homem e suas emoções pessoais. Por isto, quando a arte realiza a catarse e arrasta para esse fogo purificador as emoções mais intimas e mais vitalmente importantes de uma alma individual, o seu efeito é um efeito social (Vigotski, 1998, p.315).
}

Considera, ainda, que uma reação provida da experiência estética é um estímulo fortíssimo para posteriores atitudes, pois entende que a arte exige resposta, motiva atos e atitudes.Vigotski (2003) e Meira (2010) concordam com essa perspectiva de impulso à ação transformadora da experiência estética ao compreender que, no estético, encontra-se a possibilidade de perceber e pensar sobre tudo aquilo que qualifica a experiência humana, porque essa qualificação é o resultado da integração de todas as capacidades humanas para dialogar com o meio. A interação com o meio, qualificada pela experiência estética, deixa de ser uma simples materialidade, convertendo-se em um potencial diversificado de relações significativas. 
Como toda vivência intensa, a vivência estética cria um estado muito sensível para as ações posteriores e, naturalmente, nunca passa sem deixar marcas em nosso comportamento posterior. Toda vivência poética age como se acumulasse energia para ações futuras, Ihes dá uma nova direção e faz com que o mundo seja visto com outros olhos ${ }^{7}$ (VIGOTSKI, 2003, p. 234).

Compreendendo a experiência estética enquanto ação transformadora, que contribui para o processo formativo dos seres humanos, Dewey (2010) e Vigotski (2009) ressaltam a importância da ampliação da quantidade e da qualidade dessas experiências ao longo da vida. A partir de uma visão que considera os aspectos social, histórico e cultural envolvidos em cada etapa do desenvolvimento humano, avaliam que quanto maior o número de dados comprimidos da série contínua de percepções anteriores, mais rica e sensível pode ser a percepção atual e mais intenso o impulso para adiante do indivíduo. Nesse sentido, Dewey (2010) esclarece que graças à quantidade e à profundidade da concentração de experiências anteriores, a liberação do conhecimento adquirido, confere às experiências posteriores um alcance mais amplo, composto de um número maior de particularidades definidas no que tange à constituição do sujeito e suas formas de agir perante o mundo.

\subsection{2.}

\section{A experiência estética enquanto dimensão educativa na formação humana}

Refletindo sobre a relevância da experiência na formação e constituição humana, Benjamin (2012) e Dewey $(1979 ; 2010)$ apresentam uma preocupação comum: a pobreza de experiências. Essa carência de experiências, em aspecto quantitativo e qualitativo, é apontada pelos autores como um fato que vem se alastrando em diferentes etapas da vida e esferas da sociedade.

Dewey (1979) considera que, muitas vezes, a experiência é incipiente. As coisas são experimentadas, mas não de modo a comporem uma experiência singular, porque há distração e dispersão. As experiências começam, mas não têm alcançado o fim em nome do qual foram iniciadas. Para o autor, o problema não está na falta de experiências, mas no caráter da qualidade dessas experiências, "habitualmente má e defeituosas, defeituosas sobretudo do ponto de vista de sua conexão com futuras experiências" (Dewey, 1979, p.26).

Destaca, também, que nem todas as experiências são genuínas e nem educativas. Nesse sentido, experiência e educação não são termos equivalentes.

\footnotetext{
7 Para Benjamin (2012), o conceito de "vivência" tem compreensão distinta da utilizada por Vigotski (2003) no trecho citado. Em Benjamin (2012) vivência possui conotação finita de uma ação que se esgota no momento de sua realização, é a forma como reagimos aos choques do cotidiano. Apenas a experiência possui o caráter histórico e coletivo de ser vivido, pensado, narrado, em que a ação é compartilhada com outro, se tornando infinita.
} 
Para o autor, algumas experiências podem ser até mesmo "deseducativas", quando produzem o efeito de parar ou distorcer o desenvolvimento de novas experiências posteriores. Uma experiência pode até mesmo produzir "dureza, insensibilidade, incapacidade de responder aos apelos da vida, restringindo, portanto, a possibilidade de futuras experiências mais ricas". (DEWEY, 1979, p.14).

Sobre esse tipo de pobreza de experiência que não articula os saberes e gera, nos indivíduos, a incapacidade de responder aos apelos da vida, Benjamin (2012) salienta os drásticos resultados da guerra para a geração que viveu, entre 1914 e 1918, a mais terrível experiência universal. Para o autor, esse período iniciou uma época de baixa nas ações das experiências comunicáveis.

Não, o fenômeno não é estranho. Porque nunca houve experiências mais radicalmente desmentidas que a experiência estratégica pela guerra de trincheiras, a experiência econômica pela inflação, a experiência do corpo pela fome, a experiência moral pelos governantes (BENJAMIN, 2012, p. 42).

Os males apontados pelo autor que assolaram a população, em determinada época, perduraram historicamente e, ainda hoje, estão presentes na realidade das experiências sofridas por diferentes nações em diferentes lugares. Benjamin (2012), destaca que, com o advento da modernidade, o desenvolvimento da técnica teve consequências boas e, ao mesmo tempo, avassaladoras. E, nesse sentido, a experiência da guerra mostrou como a reprodutibilidade inconsciente da técnica e dos diferentes estilos e visões de mundo pode provocar a barbárie quando a experiência é subtraída dos seres humanos.

Para o autor, essa pobreza impele o indivíduo a agir como bárbaro, que busca começar o novo sem olhar para os traços das experiências anteriores. A pobreza a qual o autor se refere não se atrela ao fato de a humanidade aspirar pelo novo, mas sim, do fato de não se alicerçar nas experiências anteriormente construídas. Desta forma, o crescimento e a inovação resultam na pobreza, porque abandonam todas as peças do patrimônio humano para substituir pelo que é considerado atual. O autor questiona, então, qual o sentido da riqueza de ideias, da produção e reprodução de saberes, se a experiência não vincula mais os patrimônios culturais criados pela humanidade ao indivíduo.

Dewey (2010) concorda com a crítica da falta de interconexão entre os saberes produzidos nas distintas experiências:

Em muito de nossas experiências não nos interessamos pela ligação de um incidente com o que veio antes e o que vem depois. Não há um interesse que controle a rejeição ou a seleção atenta do que será organizado na experiência em evolução. As coisas acontecem, mas não são devidamente incluídas nem 
decisivamente excluídas; vagamos com a correnteza. Cedemos de acordo com a pressão externa ou fugimos e contemporizamos. Há começos e cessações, mas não inícios e conclusões autênticos. Uma coisa substitui outra, mas não a absorve nem leva adiante (DEWEY, 2010, p.116).

Para o autor, essas experiências são inestéticas e o inestético se situa dentro de dois limites: em um polo está a sucessão solta dos acontecimentos e no outro estão a suspenção e o estreitamento que avançam porque as experiências têm desenvolvido uma ligação mecânica (não perceptiva) entre si. Afirma, também, que cada vez mais se amplia a presença das experiências inestéticas e que nenhuma experiência constitui uma unidade a menos que tenha qualidade estética. É a qualidade estética que arredonda uma experiência em sua completude e unidade.

Meira (2011) e Herman (2010) concordam que, hoje, a estética está na ordem do dia. Meira (2010) salienta que o estético é primordial, pois é o que sustenta o jogo das aparências, os usos e costumes, as paixões, os afetos, os vínculos, o desejo coletivo. Pelo estético vive-se a emoção, a vibração comum e se produz novas formas de coletivização. Ao mesmo tempo em que isto acontece espontaneamente, pela própria dinâmica cultural, há também o excesso e exagero que surgem por uma ordem ideológica da dominação dos códigos e das formas de percepção que, por meio de estratégias sutis, estimulam o consumo e a superficialidade das relações. Hermann (2010) concorda com essa perspectiva ao afirmar que:

Se não fizermos pausa alguma diante das provocações visuais e auditivas a que somos submetido, nada mais vemos e ouvimos. (...). A busca desenfreada de emoções fortes pelo indivíduo moderno realiza um movimento paradoxal, pois, ao mesmo tempo em que a sensibilidade triunfa, ela retira do homem a capacidade de sentir emoções serenas, jogando-o para o delírio(HERMANN, 2010, p. 127).

A autora salienta que, nessa estetização do mundo da vida, é necessário pausa e percepção diante dos incessantes estímulos a que somos frequentemente submetidos. Vigotski (2003), nesse sentido, também contribui para a reflexão ao criticar o exagero do estético e afirmar que o caminho a ser seguido não deve ser o embelezamento da vida, mas a reelaboração criativa da realidade. Acredita ser necessário buscar uma elaboração das coisas e do próprio movimento das coisas que seja capaz de iluminar e elevar as experiências cotidianas ao nível das criativas.

Refletindo sobre a pobreza das experiências estéticas no cotidiano, Dewey (2010) considera que os inimigos do estético não são o prático nem o intelectual, e sim a monotonia, a desatenção para com as pendências, a submissão às convenções na prática e no procedimento intelectual. 
A experiência é amiúde contagiada apatia, pela inércia e pelo estereotipo. São situações em que não captamos o impacto da qualidade pelos sentidos nem o significado das coisas pelo pensamento. O "mundo" fica presente demais em nós como um fardo ou uma distração. Não nos sentimos suficientemente vivos para experimentar o estímulo provocador dos sentidos e nem para nos comovermos com o pensamento. Somos oprimidos pelo que nos cerca, ou ficamos insensíveis a isso (DEWEY, 2010, p.451).

Inércia, apatia, racionalização extrema, superficialidade das relações, dentre outros riscos apontados pelos autores, contribuem para o empobrecimento da constituição do sujeito quando ocorre sua submissão a um ambiente restritivo de experiências.

Hermann (2010) considera que a emergência do debate sobre a estética, que se intensificou no século $\mathrm{XX}$, está relacionada à desconfiança do exagero dos fundamentos racionais e à desvinculação da experiência sensível na formação humana. Meira (2011) contribui com a perspectiva ao examinar que nosso século assiste à derrocada dos absolutos científicos, teóricos e discursivos, que não conseguem mais justificar valores e sustentar o ser do homem e o sentido do humano. Assim como Benjamin (2012), considera que a história se encarregou de mostrar os efeitos da cientificidade e da reprodutibilidade inconsciente resultando em desvios estéticos praticados na cultura, pela sociedade, com fim meramente utilitário aos negócios e ao consumo. Para a autora, à semelhança da racionalidade instrumental, constata-se, hoje, a existência de uma sensibilização instrumental, desconectada de uma ética existencial.

Analisando os estudos de Dewey (2010), é possível perceber que esse efeito reside de um processo histórico resultante de inúmeras concepções psicológicas acerca do desenvolvimento humano, que alegavam ser inata e original a separação entre o organismo dos indivíduos e o meio no qual se inserem. Supunha-se que a experiência era algo que ocorria exclusivamente dentro do eu, mente ou consciência - algo autônomo que só mantinha relações externas com a cena na qual o indivíduo estava inserido. Não se pensava em todos os estados e processos psicológicos como funções de uma criatura viva que habita em seu ambiente natural. Segundo o autor, quando a ligação do eu com o mundo (e também com as várias maneiras pelas quais se interage com o mundo) é rompida, deixa de existir uma conexão unitária do ser humano. Sentimento, desejo, propósito, conhecimento e capacidade de escolha são fragmentados. Uma vez feita essa separação, foi confirmada a tese de que mente, alma e espírito poderiam existir e executar suas operações sem considerar a interação do organismo com o meio. 
A ideia de separação entre corpo e mente resultou, inevitavelmente, na criação de um dualismo entre a mente e a prática, já que esta tem que operar através do corpo. Essa concepção de mente como um ser isolado está implícita na concepção de que a experiência estética era meramente algo que se passava na "mente", isolando o estético das modalidades da experiência em que o corpo se empenha ativamente nas coisas da natureza e da vida.

Conforme elucubrado nas perspectivas teóricas de Dewey (2010). Vigotski (2009) e Benjamin (2012), que salientam que toda experiência é constituída pela interação entre os indivíduos e o mundo, pode-se compreender que não é um processo unicamente físico ou mental. Em uma experiência, coisas e eventos que fazem parte do mundo físico e social são transformados pelo contexto humano, enquanto o indivíduo se modifica e se desenvolve por meio dessa interação.

Martins, Picosque e Guerra (1998) destacam que os sentidos ajudam a revelar o mundo: ao perceber as coisas, o corpo nelas se envolve, deixando-se igualmente envolver por elas. Nessa experiência, o corpo se percebe ao mesmo tempo como vidente e sensível - sentindo conhece, conhecendo sente. Nesse sentido, consideram que o corpo é cognoscente e realiza uma reflexão enraizada na experiência sensível. Camargo (2011) coaduna com a perspectiva e contribui para a reflexão ao distinguir duas formas igualmente importantes de aquisição de conhecimento pelo ser humano: o modo intelectual/lógico e o modo estético. Considera que a cognição do modo estético pode conhecer o mundo sem conceituá-lo, mas, por outro lado, não há conceituação sem a prévia percepção sensível das coisas - desta forma, o logos sempre depende da percepção sensível. Exemplo: não estacionamos o carro na garagem somente após medir e calcular
com instrumentos e métodos o tamanho da vaga, mas geralmente nos utilizamos
da percepção visual e háptica para sentir intuitivamente o tamanho do carro e o
espaço disponível (...). Também pelo ouvido calculamos distância, distinguimos
origens, movimento, verdade e falsidade das coisas. "Calcular a olho" é uma
expressão que permite entender a existência de outras formas de pensamento que
nos auxiliam em variadíssimas situações, sem que recorramos a medidas lógicas,
claras e distintas, submetidas a métodos e instrumentos de precisão (CAMARGO,
2011, p.9-10).

As situações mencionadas exemplificam que, na maior parte de nossa experiência cotidiana, não tomamos conhecimento estritamente racional das coisas, mas usamos da memória estética como forma para lidar com as experiências da vida. $O$ modo de pensamento estético pode ser compreendido como o núcleo organizador das experiências humanas, apoiado na memória afetiva da percepção. Portanto, o processo estético de organizar as experiências pode ser considerado um modo análogo à razão formadora de verdades. "Pode- 
se dizer assim, que juntamente a uma verdade lógica, também existe uma experiência estética equivalente" (CAMARGO, 2011, p.9).

Nesse sentido, o autor esclarece que o conhecimento produzido pela estética difere qualitativamente daquele estabelecido pela lógica. Apesar de serem tipos diferentes de cognição, sensibilidade e inteligência não devem ser colocados em situação de oposição no processo de construção do conhecimento. Coadunando com a perspectiva de Dewey (2010), o autor defende que conhecer o mundo de forma lógica não exclui conhecê-lo esteticamente e vice-versa, suas diferenças qualitativas devem ser combinadas de modo a ampliar a eficiência do conhecimento.

Hermann (2010), também considera que quando a formação ocorre sem a experiência sensível, priorizando apenas as capacidades de abstração e racionalidade, aspectos importantes são perdidos. Associa a estética à possibilidade de reter particularidades do cotidiano - onde se misturam ser e aparência, vida e arte, realidade e ficção - que são irredutíveis ao pensamento estritamente racional. É importante esclarecer, concordando com a autora, que requisitar a amplificação da experiência estética na educação não se configura como uma oposição ao modo de conhecimento científico, mas sim resistência ao seu privilégio cultural nas formas de construção do conhecimento. A educação que valoriza a experiência estética, que aqui se discute, não corresponde ao desenvolvimento de capacidades estéticas, artísticas ou de competências. O que se pretende elucidar são as possibilidades de uma educação em que o indivíduo seja capaz de articular o mundo comum com aquilo que sua sensibilidade percebe, reconhecendo a pluralidade das relações.

\section{2.}

\section{Infância, educação infantil e a dimensão estética do conhecimento}

Refletir sobre a dimensão estética do conhecimento na infância e na Educação Infantil implica esclarecer que o entendimento sobre essa etapa da vida nem sempre existiu da forma como é concebido hoje. Historicamente, o modo de enxergar, tratar e inserir a criança no mundo foi exercido de maneiras distintas, seguindo o fluxo das mudanças na forma de organização, das relações de trabalho e das atividades realizadas em cada sociedade (Kramer, 1996). Ao abordar o desenvolvimento biológico da criança e as questões sociais da infância, Lajolo (2011) esclarece que:

(...) muito embora os seres humanos tenham sempre nascidos frágeis, pequeninos e leves e - quando sobrevivem... - tenham sempre ganhado altura e peso ao longo de muitos anos até que ficam fortes e seu tamanho se estabiliza, e seja sua idade 
contada por anos, por luas, ou por chuvas, o significado de ser um ser humano deste ou daquele tamanho, com muita ou com pouca altura, varia enormemente de um lugar para o outro, de um tempo para o outro (LAJOLO, 2011, p. 230).

A ideia e o sentimento acerca da infância - da maneira como é concebido hoje -, surgiram no contexto histórico e social da modernidade, em decorrência do avanço da ciência e das mudanças econômicas e sociais que contribuíram para a redução dos índices de mortalidade infantil (KRAMER 1996, 2005; KUHLMANN $J R, 2010)$.

Os estudos analisados por Kuhlmann Jr. (2010) mostram que na Idade Média não havia uma indiferença pela criança; as famílias se preocupavam pela saúde e cura de seus filhos que, passando o período da alta mortalidade, exerciam um papel produtivo direto na sociedade. A partir do século XVIII, houve uma profunda mudança nas crenças e nas estruturas do pensamento ocidental com relação à vida e ao corpo, provocando o que foi denominado como o "surgimento do sentimento de infância". Nesse momento, a inserção e o papel social da criança são, portanto, alterados: seu aprendizado passa a ser orientado pela escola, e não mais pelo cotidiano. Essa separação da criança da sociedade foi acompanhada de um sentimento de cumplicidade por parte da família, da remodelação dos espaços domésticos e de novos métodos pedagógicos "em substituição ao ensino pelas lágrimas da palmatória" (KUHLMAN JR., 2010, p. 24).

Nesse sentido, ao fazer a crítica à modernidade a partir de um olhar sensível para a infância, Benjamin (2017) considera que foi com o lluminismo que nasceu uma visão da criança moldável, que deveria ser educada com ideais de formação humanista, pois, "se o homem era piedoso, bondoso e sociável por natureza, então deveria ser possível fazer da criança, ser natural por excelência, o homem mais piedoso, mais bondoso e sociável" (BENJAMIN, 2017, p.55). Constituiu-se, assim, o início de uma educação moralista e edificante que priorizava a razão em substituição ao ensino catequista de ensinamentos ligados à religião.

A criança passou a ser compreendida como alguém que precisava ser cuidada, escolarizada e preparada para uma atuação futura. Os estudos acerca da história da infância destacam que esse sentimento moderno correspondeu a duas atitudes da sociedade perante às crianças: i) considerar um ser inocente, ingênuo e puro; ii) considerar um ser imperfeito que necessita da moralização e da educação direcionada pelo adulto. Para Kramer (1996), os dois sentimentos de infância se completam na concepção de que haveria uma "essência" ou "natureza" do que é infantil.

Dewey (2002), também refletindo sobre essa visão dualística da infância moderna, considera que depreciações extremas (moral e intelectualmente), assim 
como a idealização da criança têm suas raízes em uma falácia comum. Ambas as concepções resultam de uma compreensão acerca dos estágios de desenvolvimento compreendidos de modo fixo e isolado do contexto social no qual a criança se encontra. Para o autor, fazer comparações despropositadas entre a imaturidade da criança e a maturidade do adulto, considerando a primeira como algo que deveríamos nos livrar assim que possível é um equívoco, e igualmente perigoso é considerar a capacidade e interesses da criança como algo pronto em si, ou inato.

Contudo, é importante ressaltar que esse sentimento de infância surgiu, prioritariamente, no interior das classes médias que se formavam (no interior da burguesia). Essa concepção de infância moldável, ingênua e paparicada foi universalizada pelas classes hegemônicas com base no seu padrão de criança, partindo de critérios de idade e de dependência do adulto. Esta visão, que não tinha como foco a análise da condição infantil, mascarava a real significação social da infância. Naquela época, coexistia a miséria da população infantil desde o início da Revolução Industrial. Para a criança pobre, o padrão de idade e dependência do adulto era outro: desde muito cedo eram expostas ao trabalho em situações precárias nas ruas, fábricas, minas de carvão etc. (KRAMER 1996, 2005; KUHLMANN JR., 2010).

A partir do final do século XIX e início do século XX, o conceito de civilização passou a exigir novas instituições sociais, e, após a década de 1870, o desenvolvimento científico e tecnológico consolidou a tendência de valorização da infância, privilegiando instituições como a escola primária, o jardim de infância, a creche, os internatos. Essas instituições, inicialmente com postura paternalista e filantrópica, foram assumindo uma dimensão cada vez mais autoritária diante da população pobre e trabalhadora. "Os homens da ciência seriam os detentores da verdade, capazes de efetuar a distribuição social sob controle, na perspectiva da melhoria da raça e do cultivo ao nacionalismo" (KUHLMANN JR., 2010, p.27).

Foi com o avanço nas áreas de conhecimento da Psicologia, Sociologia e Antropologia, e com a articulação desses saberes, que começou a se fundamentar uma posição teórica contrária à miniaturização e à naturalização da criança moderna, consolidando análises a partir de um caráter histórico, ideológico e cultural. A década de 1960 foi marcada por impulso significativo no que se refere aos estudos acerca da história da infância, com a publicação de vários trabalhos na historiografia inglesa, francesa, norte-americana e italiana.

De acordo com Kramer (1996), os avanços teóricos contribuíram para o delineamento de uma concepção de infância concreta e historicamente situada, e 
não como mera natureza biológica, ou etapa idealizada de desenvolvimento psicológico, ou semente de uma sociedade futura. A percepção de como o sujeito se constitui em meio ao contexto em que se insere, sendo ativo e criativo nesse processo, passou então a se apresentar como possibilidade.

Desta forma, os signos da cultura adquiriam relevância por sua marca no processo de constituição do sujeito: adultos e crianças passaram a ser vistos como cidadãos, criadores e criaturas de cultura e da história. Sobre esse momento, a autora elenca conceitos importantes para a construção de uma nova práxis educativa crítica e criativa: sociedade em transformação, história e cultura, leitura de mundo e consciência. A orientação de uma práxis educativa sob esse viés foi importante para a constituição de um novo conceito de infância despedagogizado e desnaturalizado.

Benjamin (2017) critica contundentemente a figura do pedagogo bemintencionado que se supunha conhecedor do que é específico da natureza infantil. Essa atitude, característica do entendimento acerca da infância desenvolvida na modernidade - desde o lluminismo -, especula equivocadamente e atua unilateralmente no que produz, buscando determinar o que seria apropriado para a criança. Para o autor, não se consegue ver que o mundo está repleto dos mais variados objetos que são alvo da atenção infantil, "trata-se do preconceito de que as crianças são seres tão distantes e incomensuráveis que é preciso ser especialmente inventivo na produção do entretenimento delas" (BENJAMIN, 2017, p.57). O autor ainda esclarece que o entendimento e a proximidade com a criança desaparecem cada vez mais quando o material que se dirige a ela é fútil e superficial, "o gesto adocicado não corresponde à criança, mas às concepções distorcidas que se tem dela" (BENJAMIN, 2017, p.68).

Kramer (1996) contextualiza que, no caso brasileiro, esse processo teve início apenas na década de 1970, e teve como marcos importantes o fim da ditadura e a campanha pela anistia política, quando ganhou força a reflexão crítica sobre as questões sociais e a análise dos temas relativos à infância. Com as mudanças na ordem política e social vigente, houve um movimento de mergulho nas pesquisas teóricas com o objetivo de compreender a visão de infância presente no senso comum que dominava o cenário brasileiro.

A autora destaca que, naquele momento, havia uma intensa visão marginalizadora e preconceituosa das crianças das classes populares. A sociedade brasileira tinha como base um conceito de criança abstrato, delineado com padrões fixos de desenvolvimento, de linguagem e de socialização. Essa visão acerca da infância, apesar de romper com a explicação estritamente 
biológica, instaurou um determinismo social que atribuía a culpa pelo fracasso na escola a fatores sociais, culturais e ambientais responsabilizando os que sofriam. Era, portanto, "uma infância definida pela falta, por aquilo que não é, que não tem, que não conhece e, fundamentalmente, uma infância compreendida pela negação da sua humanidade" (KRAMER, 1996, p.16).

Kuhlmann Jr. (2010) corrobora com a perspectiva ao ressaltar que, nesse momento, a imagem da população pobre era tida como ameaça social a ser controlada. A pobreza era interpretada por generalizações e caracterizações, fazendo com que a criança pobre fosse identificada como sinônimo de menino de rua, trombadinha ou menor infrator. Essa concepção de pobreza foi forjada nos moldes das concepções assistenciais do início do século XX, que culpabilizava as famílias e grupos sociais.

Como resultado desse cenário político e do intenso debate educacional, que se desencadeou devido aos estudos iniciados na década de 1970, houve a consolidação de um marco teórico e de políticas em defesa da infância no Brasil considerada na sua dimensão cidadã de direitos. "A criança, ao longo destas décadas, deixa de ser alguém que não é (pelo menos nas discussões acadêmicas) e passa à condição de cidadã (pelo menos na lei...)" (KRAMER, 1996, p.17).

$\mathrm{O}$ debate incitado pelas pesquisas acadêmicas, aliado à volta do estado democrático e à luta dos movimentos sociais no período pré-constituinte, foram cruciais para o reconhecimento dos direitos sociais da infância. O resultado desse movimento refletiu na garantia de direitos na Constituição Brasileira (BRASIL,1988) e na criação do Estatuto da Criança e do Adolescente (BRASIL, 1990), onde a infância passou a ser alvo de atenção, gerando uma demanda de políticas públicas específicas que garantissem os direitos básicos para seu pleno desenvolvimento.

Apesar desses avanços significativos no reconhecimento da infância, Kramer (2005) considera que, na contemporaneidade, vive-se o paradoxo de ter um conhecimento teórico avançado sobre o tema, enquanto se assiste à incapacidade de lidar com as populações infantis. Ainda se incorre no erro do adultocentrismo, deixando de ver o mundo que, de fato, se apresenta às crianças.

Para a autora, o sentido da dependência da criança diante do adulto, instaurado pela burguesia, é um fato social (não apenas natural) que varia de acordo com a classe social. A significação econômica da infância está na base do valor atribuído à criança nos vários domínios da realidade social. Logo, a criança não é valorizada de maneira uniforme; as relações entre crianças e adultos são 
heterogêneas bem como seu valor em cada classe de uma mesma sociedade (KRAMER, 1996).

Analisando a realidade das crianças no Brasil, esse fator assume ainda mais um papel preponderante. Devido à diversidade de aspectos sociais, culturais e políticos, em uma sociedade de classes como a brasileira, enfatiza-se a séria desigualdade das populações infantis, inseridas em contextos econômicos e políticos que produziram a situação atual.

Para Kramer (2015), a ideia de projetar a infância como esperança de um futuro melhor retira as crianças de condições sociais e econômicas atuais e reais e abre mão de pensar o presente, jogando para depois as alternativas de mudança.

Se atualmente, por um lado, temos vivido manifestações de reconhecimento dos direitos das crianças em diferentes níveis, por outro, continuamos a presenciar massacres das crianças e jovens, exploração, violência sexual, fome e maus-tratos nas instituições educacionais (KUHLMANN JR., 2010, p.20).

Indo na contramão da infância romantizada e idealizada, Benjamin (2017, p.50), ainda na década do século XX, descortina "a seriedade da infância, plena de afinidades com a tristeza do adulto". Tal afinidade resulta do fato que as crianças não constituem nenhuma comunidade isolada, ao contrário, fazem parte do povo e da classe a que pertencem.

Para Kuhlmann Jr. (2010), se por um lado a infância representa um outro mundo (do qual se produz uma imagem mítica), por outro, ressalta que não há outro mundo, pois, a interação é o terreno no qual a criança se desenvolve. Crianças participam das relações sociais, que não são exclusivamente um processo psicológico: é social, cultural e histórico. As crianças buscam essa participação porque as relações sociais são parte integrante de suas vidas e da forma como vão se constituindo, portanto, se apropriam de valores e comportamentos próprios de seu tempo e lugar. $\mathrm{O}$ autor defende que a infância é uma condição da criança, um conjunto de experiências vividas em diferentes lugares históricos, geográficos e sociais. Desta forma, deve ser compreendida como algo maior, e mais significativo, do que uma representação do adulto sobre esta fase da vida.

Ao buscar compreender as concepções de infância hoje, Kuhlmann Jr. (2010) considera que é preciso conhecer as representações de infância e considerar a criança concreta, localizada nas relações sociais e reconhecê-las como produtoras da história. A partir dessa perspectiva, julga que se torna difícil afirmar se uma criança teve ou não infância, seria melhor perguntar como é, ou como foi sua infância. Sob essa compreensão, reconhecer as diferentes infâncias 
é importante, pois traz à tona o fato que "as crianças concretas, na sua materialidade, no seu nascer, no seu viver ou morrer, expressam a inevitabilidade da história e nela se fazem presentes, nos seus mais diferentes momentos" (KUHLMANN JR., 2010, p.31). São, portanto, sujeitos sociais e históricos, marcados pelas contradições das sociedades em que se encontram inseridas.

A criança não é filhote do homem, ser em maturação biológica; ela não se resume a ser alguém que não é, mas que se tornará (adulto, no dia em deixar de ser criança). Defendo uma concepção de criança que reconhece o que é específico da infância - seu poder de imaginação, fantasia, criação - e entende as crianças como cidadãs, pessoas que produzem cultura e são nela produzidas, que possuem um olhar crítico que vira pelo avesso a ordem das coisas, subvertendo essa ordem (KRAMER, 2005, p.05).

Nesse sentido, Benjamin (2017) ressalta que a criança consegue lidar com o conteúdo da vida de maneira tão soberana e descontraída, como o faz em suas brincadeiras. Destaca a capacidade de a criança construir o seu mundo criativamente se apropriando dos objetos e assuntos da vida adulta, estabelecendo vínculos entre esses elementos e o seu mundo. Dos objetos e ações da vida, as crianças conhecem e reconhecem o mundo, mas não somente a partir da reprodução ou imitação, pois são capazes de estabelecer uma relação nova e incoerente (na perspectiva do adulto) com o que possuem como material de suas experiências.

Enxergando e se apropriando do mundo desta forma, aprende-se a valorizar a potencialidade da imaginação, da arte, da dimensão lúdica, da poesia. Para tanto, é crucial políticas que incentivem a ampliação da formação cultural, desde a mais tenra idade, de modo a enriquecer as experiências que potencializam essas capacidades (KRAMER, 2005).

\subsection{1. \\ Infância e a dimensão estética do conhecimento}

Para Vigotski (2009), a possibilidade de criação humana, em qualquer etapa da vida, é ancorada na experiência. Portanto, sugere que se viabilize a ampliação de experiência das crianças ao conhecimento cultural produzido historicamente pela humanidade para que sejam criadas bases suficientemente sólidas para sua atividade de criação. Pois, "quanto mais a criança viu, ouviu e vivenciou, mais ela sabe e assimilou; quanto maior a quantidade de elementos da realidade de que ela dispõe em sua experiência - sendo as demais circunstâncias as mesmas -, mais significativa e produtiva será a atividade de sua imaginação (VIGOTSKI, 2009, p. 23).

Pillar (2011) corrobora a perspectiva ao afirmar que a forma de perceber e apreender o mundo tem sempre a marca do conhecimento e da imaginação de 
quem observa, ou seja, depende do sujeito e das estruturas mentais que possui no momento. Diferentes pessoas podem ler uma mesma realidade e chegar a conclusões bem distintas. Isto porque o olhar de cada um é impregnado de experiências anteriores, associações, lembranças, fantasias, interpretações etc. Desse modo, podemos lançar diferentes olhares e fazer uma pluralidade de leituras sobre as distintas formas de existir no mundo.

Martins, Picosque e Guerra (1998) destacam que muito do que sabemos sobre o pensamento e o sentimento dos mais diversos povos, países, épocas e pessoas são oriundos de conhecimentos que obtivemos única e exclusivamente por meio de suas músicas, teatro, poesia, pintura, dança, cinema etc. É por meio das linguagens artísticas que também podemos compreender o mundo das culturas e a constituição do sujeito particular. Nesse processo, que envolve a compreensão e a interpretação das formas sensíveis e subjetivas que compõem a humanidade e suas diversas culturas, fronteiras na constituição de si podem ser ultrapassadas.

Vigotski (1998), analisando o papel e a influência da arte na vida, ressalta que é necessário levar em conta as peculiaridades da reação estética da criança, e destaca dois aspectos fundamentais em sua relação com a arte: i) a existência precoce de uma orientação especial exigida pela arte - a capacidade de transposição inalienável das funções dos fenômenos e dos objetos da vida para o absurdo desejável (dos contos, fábulas, músicas etc) que permite mergulhar em aventuras alheias; ii) uma afinidade entre a arte e o jogo - nos jogos e brincadeiras infantis, em todas as suas confusões, observa-se uma ordem ideal. Nessa "loucura" existe um sistema compreendido pelo grupo.

Ao incorporar a criança no topsy-turvy-world ${ }^{\beta}$, num mundo de pernas para o ar, nós não só não prejudicamos o seu trabalho intelectual, como, ao contrário, contribuimos para ele, uma vez que na própria criança existe a aspiração a criar para si esse mundo às avessas, para, assim, se afirmar com mais segurança nas leis que regem o mundo real. Esses pequenos absurdos seriam perigosos para a criança se bloqueassem as reais e autênticas interações de idéias e objetos. Mas, além de não bloquearem, ainda as promovem, ressaltam, destacam (VIGOTSKI, 1998, p. 327-328).

Vemos aqui como a arte se desdobra na criança e como, para o estímulo à sua percepção, é necessário ao mesmo tempo observar o verdadeiro estado das coisas do mundo na qual estão inseridas e poder subvertê-los. É na percepção do estado natural das coisas e no seu desvio contraditório que Vigotski (1998)

\footnotetext{
8 (Em um estado de ser) confuso, não bem organizado, ou dando importância a coisas inesperadas. Fonte: <dictionary.cambridge.org >. Acesso em: 09 nov. 2018. (tradução da autora).
} 
considera surgir o efeito da arte nas crianças, pois, para a criança o absurdo é um instrumento de domínio da realidade onde ela apreende e reelabora.

Vecchi (2006) concorda com essa perspectiva otimista da arte no processo em que a criança é vista como sujeito na constituição de si. Acredita que o sentimento estético pode nutrir um conhecimento que não se alimenta apenas da informação comunicada de forma lógica e racionalizada, mas que leve também a uma relação de sensibilidade e empatia com as coisas, solicitando a criação de distintas conexões.

Enfatiza, ainda, que o sentimento estético ocupa diversos campos, portanto, não está ligado estritamente à arte. É uma aspiração de beleza encontrada em todos os povos, e em todas as culturas, atuais e do passado. Para a autora, basta olhar a história da espécie humana para encontrar, em todas as épocas e culturas, a presença de um cuidado formal e atenção à dimensão estética. Tal cuidado não é dedicado somente às grandes obras de arte, mas a todos os testemunhos da vida humana nos quais emergem gestos de cuidado, busca de qualidade e beleza.

Creio que a dimensão estética é uma atitude cotidiana, uma relação empática e sensível com o ambiente, um fio que conecta e une as coisas, um ar que leva a preferir um gesto a outro, a escolher um objeto, a escolher uma cor, um pensamento; escolhas em que harmonia, cuidado, prazer para a mente e os sentidos são percebidos. A dimensão estética pressupõe um olhar que descobre, que admira e se move. É o oposto da indiferença, da negligência e do conformismo (VECCHI, 2006, p. 15-16, tradução da autora).

Oswald (2011), refletindo sobre a dimensão estética do conhecimento na constituição do sujeito, desde a infância, também ressalta sua perspectiva cotidiana, sensível e social.

A experiência estética é aquela que sensibiliza, que emociona, não tem a ver necessariamente com o belo, com a contemplação de uma obra de arte, com um estado de transe que supostamente traz inspiração para o artista executar sua obra. Experimentar algo esteticamente é impregnar-se do mundo físico e social pelos sentidos (OSWALD, 2011, p.25).

Contudo, é importante ressaltar que os estudos ${ }^{9}$ que se dedicam a discutir a dimensão estética na formação do sujeito, apontam que não é fácil ou simples tratar dessa temática em um mundo dominado por injustiças, pobreza, indiferenças, abuso, crueldade e racionalização extrema. Por vezes, discutir a necessidade do enriquecimento dessas experiências, por meio da interação com diferentes práticas culturais, parece efêmero.

Entretanto, os pesquisadores reafirmam a necessidade de persistir nos estudos e práticas que se debruçam sobre a formação humana. Assegurar a dimensão estética do conhecimento como direito fundamental e inalienável, desde

\footnotetext{
9 Hermann (2010), Vecchi (2006), Kramer (2005), Camargo (2011), Pillar (2011), dentre outros.
} 
a infância, é resistir contra a barbárie. Endossam uma perspectiva de humanização em que, por meio do resgate da experiência, seja adquirida a capacidade de ler o mundo de forma plural. Em diferentes contextos, podem ser promovidas experiências de educação e socialização, com práticas e ações coletivas entre os indivíduos (em todas as etapas da vida) que incitem a solidariedade, a empatia e o sentido de pertencimento.

Ao abordar a dimensão estética que permeia a infância, Vecchi (2006) coaduna com a perspectiva de Benjamin (2017) e considera que o entendimento acerca da infância é aprisionado em um modelo de vida determinado, conformista, simplificado e distante de sua realidade. Essa forma de conceber a infância reflete diretamente nas escolhas estéticas que Ihes são dirigidas - geralmente empobrecidas pela mídia e mercado "especializado".

Diante dessa realidade, a autora considera que as especificidades que caracterizam a dimensão estética na infância devem ser analisadas com atenção. A tensão estética - com suas peculiaridades de empatia, de busca de relacionamento, de estrutura que comunica, mas também de graça, de ironia, de provocação e de ausência de determinismo - serve de suporte ao processo de escuta, diálogo e construção com e entre as crianças.

Para tanto, deve-se ter em mente que o que é singular na formação do indivíduo, desde a infância, é a ideia de que a pessoa se constitui num vínculo constante com o mundo. E o mundo, compreendido em sua pluralidade, que emerge também pela imaginação e fantasia, é algo que se associa às possibilidades contidas na experiência estética (HERMANN, 2010; DEWEY, 2010). Kramer (2005) corrobora com essa perspectiva ao afirmar que:

O que singulariza o ser humano é essa pluralidade de experiências, de valores e saberes presentes na dança, música, na produção de objetos, nas festas civis ou religiosas, nos modos de cuidar das crianças, da terra, dos alimentos, roupas, nas trajetórias contadas pelas famílias, grupos, etnias. Essa pluralidade cultural materializa-se também na literatura, no cinema, arte, música, fotografia, teatro, pintura, escultura, nos museus, na arquitetura (KRAMER, 2005, p. 08).

Para a autora, experiências com produção cultural que têm dimensão artística (ou estética) são importantes por serem capazes de inquietar, de provocar a reflexão para além do momento em que acontecem. Ao abordara relação das crianças com essas produções, destaca que as experiências na cultura "podem ensinar a utopia e favorecer o convite à reflexão, a pensar sobre o sentido da vida individual e coletiva" (KRAMER, 2005, p. 10-11).

\subsection{2.}

\section{Educação infantil e a experiência estética}


Dewey (2002) considera que a educação escolar na infância representa a possibilidade de desenvolvimento inerente à experiência imediata (e ainda imperfeita) da criança ${ }^{10}$. Para promover essa oportunidade, salienta que é preciso o desprendimento da noção prejudicial de que existe um hiato de qualidade entre a experiência da criança e o conteúdo dos saberes que lhe é destinado.

Reconhecendo a criança enquanto sujeito ativo e curioso, entende que a orientação da formação escolar deve buscar sua base nas experiências advindas do impulso curioso da criança para com as coisas do mundo. Nesse ambiente, onde aprender certamente é importante, destaca principalmente a importância de viver, e de aprender através da interação com essa vivência.

A questão da relação entre a escola e a vida da criança resume-se, no fundo, a isto (...) acreditarmos a um tempo na vida e na vida da criança, então toda a história e toda ciência, passarão a ser instrumentos de sedução e ferramentas de cultura para sua imaginação, e, através disso, para o enriquecimento e organização da sua vida (DEWEY, 2002, p. 58).

Entretanto, ao reconhecer o desenvolvimento infantil como um processo definido com leis próprias, ressalta a necessidade de condições adequadas. $O$ autor considera que a escola, ao planejar, organizar, sistematizar e estimular as atividades e interesses das crianças, transforma esses elementos para além da expressão de impulsos. Satisfazer realmente a um impulso da criança, implica colocá-lo em prática - que envolve se deparar com obstáculos, familiarizar-se com materiais, dar mostras de engenhosidades, paciência e persistência - e repercute em conhecimentos. Quando a criança tenta e é estimulada a concretizar seu impulso, tem a possibilidade de definir suas ideias e transformá-las. Nesse processo educativo, ocorre um misto de observação, memória e imaginação. É uma reconstrução contínua, passando da experiência atual da criança para aquela representada pelo corpo organizado de conhecimentos.

Para o autor, as várias disciplinas curriculares, ou campos de saber, nada mais são do que esse "corpo de saber organizado" advindo das experiências que incorporaram resultados cumulativos dos esforços, das lutas e das conquistas da humanidade ao longo dos tempos. Contudo, na História da Educação, esses saberes foram sendo apresentados como uma mera acumulação, em uma miscelânea de pedaços separados da experiência, de forma organizada e sistematizada. Dewey (2002) destaca, então, que a experiência sistematizada e

\footnotetext{
${ }^{10}$ Coadunando com a perspectiva de Vigotski (2009), Dewey (2010) considera pernicioso os estudos que corroboram o senso comum de que a criança de uma dada idade possui um conjunto de propósitos e de interesses positivos/ricos a ser cultivado tal como se apresenta. Na realidade, os interesses devem ser interpretados como atitudes para experiências possíveis; não são ainda realizações efetivas; o seu valor reside no impulso que fornecem, é algo com que fazer.
} 
definida da mente adulta tem lugar na interpretação da vida da criança, que deve valorizar como suas experiências se revelam (no imediato) e que, posteriormente, pode ser enriquecida e ampliada ao passar pela orientação do adulto/educador.

Caso não seja um verniz superficial, um folheado de mogno sobre a madeira vulgar, a cultura é seguramente isto - o desenvolvimento da imaginação em termos de flexibilidade, âmbito e solidariedade, até que a vida que cada indivíduo vive fique repassada pela vida da natureza e da sociedade. Quando a natureza e a sociedade puderem viver na sala de aula, quando os métodos e ferramentas da aprendizagem estiverem subordinados à substância da experiência, então haverá oportunidade para esta identificação e a cultura será o santo-e-senha democrático (DEWEY, 2002, p. 58).

Refletindo sobre a educação para a infância, Kramer (2015) coaduna com a perspectiva teórica de se trabalhar com crianças de maneira a considerar seu contexto de origem, seu desenvolvimento e o acesso aos conhecimentos, direito social de todos. Escolas são espaços de circulação das culturas, das tradições culturais, costumes e valores de diferentes grupos. Desde a mais tenra idade, a criança traz experiências e saberes dos conhecimentos culturais da comunidade na qual está inserida. Nesse espaço, repleto de indivíduos plurais, o maior objetivo institucional deveria ser a construção de uma educação fundada no reconhecimento do outro e suas diferenças de cultura, etnia, religião, gênero, classe social, idade. A autora também ressalta que para alcançar tal objetivo é necessária uma formação cultural que assegure sua dimensão de experiência crítica. A formação cultural contra a barbárie não admite práticas que tratem a cultura como verniz superficial.

Também discutindo a educação para a infância que englobe a pluralidade, Vecchi (2006) ressalta que a sociedade futura, cada vez mais mestiça, intercultural e complexa, amplia a necessidade de formação de sujeitos que se coloquem em uma atitude de escuta em relação aos outros. Observar para conhecer e entender deve ser o alicerce da experiência educativa que tem a dimensão estética como ponto chave.

Examinando as possibilidades da experiência estética na infância, Vigotski (2003) destaca que um erro cometido por muito tempo na educação foi reduzi-la ao sentimento do agradável, vendo nisso um fim em si mesmo. Para o autor, é um equívoco reduzir todo o significado das vivências estéticas ao sentimento imediato de gozo e alegria que pode despertar na criança. Esclarece que esse erro não é puramente pedagógico, provém do entendimento na própria ciência psicológica com relação às questões da estética que, durante muito tempo, persistiu no critério de que a percepção estética constituía uma vivência totalmente passiva, uma total entrega à impressão. Nesse sentido, o autor alerta que: 
Quem pensa cultivar a estética na educação como fonte de prazer sempre corre o risco de encontrar na primeira guloseima e no primeiro passeio os mais fortes concorrentes. A particularidade da idade infantil reside justamente no fato de que a força direta de uma vivência real concreta é muito mais significativa para a criança que a força de uma emoção imaginária (VIGOTSKI, 2003, p.28-29).

Nesse sentido, Kramer (2015) também reitera os riscos de uma educação ilustrada e livresca que, também por muito tempo, ensinou a conformação e a obediência de uma concepção hegemônica acerca da produção cultural e artística da humanidade. Contrariamente à perspectiva de ensino que se utiliza da produção cultural e da arte como enfeite, ou para ensinar conteúdos escolares, defende políticas educacionais para a infância que assegurem experiências críticas com a cultura pelo seu potencial humanizador e formador. No que se refere ao entendimento de "experiências críticas coma cultura", compreende uma relação dialética no encontro com as diversas produções e linguagens artísticas (fruto da experiência acumulada pela humanidade) em que se resgatam trajetórias e relatos, se provoca a discussão de valores e crenças, se suscita o repensar do sentido da vida, da sociedade contemporânea e do papel de cada um.

Para Vigotski (2003), a educação que valoriza a perspectiva estética deve supor que as maiores possibilidades criativas dos indivíduos decorrem dessa capacidade dialética do ser humano com seu meio. Portanto, a educação precisa ser orientada de forma a desenvolver e manter essas possibilidades estéticas nas ações cotidianas.
Aqui está a chave para a tarefa mais importante da educação estética: inserir as reações estéticas na própria vida. A arte transforma a realidade não só em construções da fantasia, mas também na elaboração real das coisas, dos objetos e das situações. A moradia e a vestimenta, a conversa e a leitura, a festa escolar e 0 modo de caminhar: tudo isso pode servir como material sumamente promissor para a elaboração estética. A beleza deve deixar de ser uma coisa rara e própria das festas para se transformar em uma exigência da vida cotidiana (VIGOTSKI, 2003, p. 239).

Kramer (1996) também reflete sobre esse potencial criativo dos seres humanos que se manifesta desde a infância. As crianças precisam criar, construir e desconstruir, precisam de espaços cuja relação prioritária com os elementos naturais e com os artefatos tenha como objetivo a experiência com a cultura, com a arte e com a ciência. Essa percepção ampla da criança - como cidadã, produtora de cultura - tem implicações profundas para o trabalho em creches, pré-escolas e sua relação com outros espaços das cidades de caráter científico, artístico e cultural. Contudo, destaca que ainda falta a valorização dessa relação entre as escolas de E.I e as instituições culturais. Nesse sentido, a autora salienta a 
importância de políticas públicas voltadas para a infância no que tange à garantia de direitos nos diferentes âmbitos sociais.

No contexto brasileiro, conforme discutido anteriormente, a partir de meados dos anos 1980, os movimentos em defesa das populações infantis alcançaram marcos institucionais importantes para a promoção de políticas públicas para a infância. No que se refere à educação, a primeira delas foi a Constituição Brasileira (BRASIL, 1988), que estabeleceu o atendimento em creche e pré-escola como um dever do Estado e um direito da criança de 0 a 6 anos de idade. Posteriormente, em 1996, a elaboração da Lei de Diretrizes e Bases da Educação Nacional (LDB) (BRASIL, 1996) reconheceu a Educação Infantil como etapa da educação básica a ser oferecida conforme a disponibilidade dos municípios nas modalidades creche (para crianças de 0 a 3 anos) e pré-escola (para crianças de 4 a 6 anos). Em 1998, foi publicado o Referencial Curricular Nacional para a Educação Infantil (RCNEI) (BRASIL, 1998) que reuniu objetivos, conteúdos e orientações didáticas para as instituições escolares de E.I. No ano de 2009, a execução das Diretrizes Curriculares Nacionais para a Educação Infantil (DCNEI) (BRASIL, 2009a) buscaram orientar o planejamento curricular das escolas e trouxe como marco conceitual a indissociabilidade entre o cuidar e educar. Ainda no ano de 2009, com a Emenda Constitucional no 59/2009 (BRASIL, 2009b), a Educação Infantil passou a ser obrigatória para todas as crianças a partir de quatro anos de idade. E, no ano de 2017, foi lançada a Base Nacional Comum Curricular (BNCC) (BRASIL, 2016) que institui e orienta a implantação de um planejamento curricular ao longo de todas as etapas da educação básica.

A ampliação do acesso à educação para as crianças é um fator positivo, entretanto, não garante a qualidade do desenvolvimento humano e social que é propagado nas instituições escolares. Por muito tempo, a Educação Infantil no Brasil assumiu apenas o caráter assistencial, sem considerar uma dimensão educativa ampla na formação do sujeito. No que tange à educação pautada na experiência estética e cultural das crianças e a relação com os equipamentos culturais algumas observações podem ser destacadas ao examinar os principais documentos estruturantes do segmento da Educação Infantil brasileira.

O Referencial Curricular Nacional para a Educação Infantil (BRASIL, 1998) teve como foco propor o desenvolvimento integral da criança, mas sua concepção de infância ainda era atrelada à visão de ser humano que responde aos estímulos do adulto. O documento buscou esclarecer o que deveria ser ensinado nessa etapa do ensino e foi organizado em torno de dois objetivos gerais (formação pessoal e social e conhecimento de mundo) que se subdividem em sete 
eixos a serem trabalhados de forma integrada: identidade e autonomia, movimento, música, artes visuais, matemática, linguagem oral e escrita, natureza/sociedade.

No que se refere ao entendimento acerca da relação com a estética e com os equipamentos culturais, define que a qualidade das experiências nessa etapa de ensino deve estar embasada no princípio de "acesso das crianças aos bens socioculturais disponíveis, ampliando o desenvolvimento das capacidades relativas à expressão, à comunicação, à interação social, ao pensamento, à ética e à estética (BRASIL,1998, p.13). Entende que o processo de educar "poderá auxiliar o desenvolvimento das capacidades de apropriação e conhecimento das potencialidades corporais, afetivas, emocionais, estéticas e éticas, felizes e saudáveis" (BRASIL, 1998, p.23) das crianças.

Entretanto, as poucas vezes em que o termo "estético" aparece ao longo do documento, é possível constatar uma compreensão passiva no que tange às experiências estéticas que podem ser promovidas junto às crianças e restrita às áreas de arte e música, conforme mostram os trechos abaixo:

(...) as capacidades de ordem estética estão associadas à possibilidade de produção artística e apreciação desta produção oriundas de diferentes culturas (BRASIL, 1998, p.48).

Tanto a creche quanto a pré-escola precisam considerar os cuidados com a ventilação, insolação, segurança, conforto, estética e higiene do ambiente, objetos, utensílios e brinquedos (BRASIL, 1998, p. 51).

Orientações didáticas para crianças de 4 a 6 anos - expressividade: Valorização e ampliação das possibilidades estéticas do movimento pelo conhecimento e utilização de diferentes modalidades de dança (BRASIL, 1998, p.32).

Ouvir música, aprender uma canção, brincar de roda, realizar brinquedos rítmicos, jogos de mãos 11 etc., são atividades que despertam, estimulam e desenvolvem o gosto pela atividade musical, além de atenderem a necessidades de expressão que passam pela esfera afetiva, estética e cognitiva (BRASIL,1998, p.48).

O desenvolvimento da imaginação criadora, da expressão, da sensibilidade e das capacidades estéticas das crianças poderão ocorrer no fazer artístico, assim como no contato com a produção de arte presente nos museus, igrejas, livros, reproduções, revistas, gibis, vídeos, CD-ROM, ateliês25 de artistas e artesãos regionais, feiras de objetos, espaços urbanos etc. (BRASIL, 1998, p.89).

No que é concernente à relação das instituições escolares de E.I com outros espaços e equipamentos culturais da cidade, afirma que "a aprendizagem transcende o espaço da sala, toma conta da área externa e de outros espaços da instituição e fora dela. A pracinha, o supermercado, a feira, o circo, o zoológico, a biblioteca, a padaria etc. são mais do que locais para simples passeio, podendo enriquecer e potencializar as aprendizagens" (BRASIL, 1998, p.58).

Nas orientações gerais para o professor, enfatiza a promoção das experiências diretas através de passeios nos arredores da instituição ou em locais 
mais distantes, como a ida a museus, centros culturais, granjas, feiras, teatros, zoológicos, jardins botânicos, parques etc., que permitem a observação direta da paisagem, a exploração ativa do meio natural e social, ampliando a possibilidade de observação da criança. Ainda no trecho de orientações gerais para professores cita a importância de que a criança seja estimulada a fazer leitura de objetos e imagens antigas produzidas pelo homem, como desenhos, mapas, fotografias, pinturas, filmagens etc., - que pertencem às famílias, museus, vídeos, filmes e programas de televisão -com o intuito de analisar, em distintas momentos, o modo de vida de diferentes grupos sociais.

Entretanto, o único trecho das orientações didáticas em que aparece a recomendação de visitas às instituições culturais, no eixo "natureza e sociedade", está inserido apenas no direcionamento para crianças a partir dos quatro anos de idade.

As Diretrizes Curriculares Nacionais para a Educação Infantil (BRASIL, 2009) foram responsáveis por ampliar o olhar acerca da concepção de infância, enfatizando as interações sociais como condição essencial para o aprendizado. Colocou a criança como sujeito no centro do processo educativo a ser desenvolvido com diferentes práticas cotidianas por meio das interações. Evoca como eixos estruturantes a interação e a brincadeira e propõe a articulação das diferentes linguagens para a organização curricular e didática.

O documento - que alicerçou a E.I nos princípios éticos, políticos e estéticos - enfatiza a importância de que a criança tenha acesso ao conhecimento cultural, científico, histórico e natural desde a mais tenra idade. Como princípio estético, compreende a sensibilidade, a criatividade, a ludicidade e a liberdade de expressão nas diferentes manifestações artísticas e culturais. Tendo como eixo norteador a interação e a brincadeira, propõe a garantia de experiências que "possibilitem vivências éticas e estéticas com outras crianças e grupos culturais, que alarguem seus padrões de referência e de identidades no diálogo e conhecimento da diversidade" (BRASIL, 2009, p.26).

Reconhece a dimensão estética da criança, desde que sejam respeitadas suas especificidades e o conhecimento seja pautado no respeito e na diversidade. Estipula, portanto, que as propostas pedagógicas devem organizar materiais, espaços e tempos de forma a assegurar: (i) a promoção da igualdade de oportunidades educacionais entre as crianças de diferentes classes sociais no que se refere ao acesso a bens culturais; (ii) a indivisibilidade das dimensões expressivo motora, afetiva, cognitiva, linguística, ética, estética e sociocultural da criança; (iii) o reconhecimento, a valorização, o respeito e a apropriação pelas 
crianças, por meio da interação, com as contribuições histórico-culturais dos povos indígenas, afrodescendentes, asiáticos, europeus e de outros países da América com práticas de combate ao racismo e à discriminação.

A Base Nacional Curricular Comum (BRASIL, 2017) segue as DCNEI ao considerar que, na Educação Infantil, as aprendizagens e o desenvolvimento da criança têm como eixos estruturantes as interações e a brincadeira. Tendo em vista esses eixos estruturantes das práticas pedagógicas, assegura seis direitos de aprendizagem e desenvolvimento (conviver, brincar, participar, explorar, expressar e conhecer-se) e propõe uma organização curricular estruturada em cinco campos de experiências, no âmbito dos quais são definidos os objetivos de aprendizagem e desenvolvimento.

No que tange à temática de interesse desta pesquisa, no campo dos direitos de aprendizagem, o documento reconhece a importância de possibilitar experiências com a cultura dentro e fora dos espaços escolares ao afirmar que as práticas na E.I devem assegurar à criança o direito de "explorar movimentos, gestos, sons, formas, texturas, cores, palavras, emoções, transformações, relacionamentos, histórias, objetos, elementos da natureza, na escola e fora dela, ampliando seus saberes sobre a cultura, em suas diversas modalidades: as artes, a escrita, a ciência e a tecnologia".

Já os campos de experiências, arranjo curricular a ser seguido, sugerem que as escolas de E.I devem acolher as situações, os saberes e as experiências concretas da vida cotidiana das crianças, entrelaçando-os aos conhecimentos que fazem parte do patrimônio cultural. O documento esclarece que a definição e a denominação dos cinco campos de experiências (o eu, o outro e o nós; corpo, gestos e movimentos; traços, sons, cores e formas; escuta, fala, pensamento e imaginação; espaços, tempos, quantidades, relações e transformações) também se baseiam no que dispõem as DCNEI em relação aos saberes e conhecimentos fundamentais a serem propiciados às crianças.

Campo de Experiências 1- o eu, o outro e o nós:(...) na Educação Infantil, é preciso criar oportunidades para que as crianças entrem em contato com outros grupos sociais e culturais, outros modos de vida, diferentes atitudes, técnicas e rituais de cuidados pessoais e do grupo, costumes, celebrações e narrativas. Nessas experiências, elas podem ampliar o modo de perceber a si mesmas e ao outro, valorizar sua identidade, respeitar os outros e reconhecer as diferenças que nos constituem como seres humanos (BRASIL, 2016). ${ }^{11}$

Apesar de ressaltar os laços estreitos com as orientações das DCNEI, os princípios éticos, políticos e estéticos são suprimidos, não sendo mencionados no

11 As informações sobre Educação Infantil na BNCC estão disponíveis em $<$ http://basenacionalcomum.mec.gov.br/abase/\#infantil>. Acesso em: 02 fev. 2018 
documento da BNCC. Mesmo enfatizando a prioridade das experiências, o termo "estético", aparece uma única vez (em todo o documento) no campo de experiência "traços, sons, cores e formas", onde a criança é interpretada como sujeito ativo e participativo das experiências estéticas que podem ser desenvolvidas.

Campo de Experiências 3 - traços, sons, cores e formas: Conviver com diferentes manifestações artísticas, culturais e científicas, locais e universais, no cotidiano da instituição escolar, possibilita às crianças, por meio de experiências diversificadas, vivenciar diversas formas de expressão e linguagens, como as artes visuais (pintura, modelagem, colagem, fotografia etc.), a música, o teatro, a dança e o audiovisual, entre outras. Com base nessas experiências, elas se expressam por várias linguagens, criando suas próprias produções artísticas ou culturais, exercitando a autoria (coletiva e individual) com sons, traços, gestos, danças, mímicas, encenações, canções, desenhos, modelagens, manipulação de diversos materiais e de recursos tecnológicos. Essas experiências contribuem para que, desde muito pequenas, as crianças desenvolvam senso estético e crítico, o conhecimento de si mesmas, dos outros e da realidade que as cerca (BRASIL, 2016). ${ }^{12}$

Analisando os documentos supracitados, norteadores da E.I, é possível perceber que a compreensão acerca da dimensão estética na infância e a relação profícua que pode ser estabelecida com os diferentes espaços de cultura, para além das escolas, é constituída por interpretações diferenciadas, avanços teóricos e supressões textuais. Estar atento às legislações é importante para que se possa garantir a cobrança de incentivos que priorizem a dimensão estética na educação, desde a infância, a partir de experiências culturais diversas que podem ocorrer em distintos lugares da cidade. Para além de olhar a dimensão das escolas, é preciso olhar também o lado das instituições culturais: Qual é o papel dos diferentes espaços culturais na formação das crianças? Esses espaços têm exercido esse papel? Podemos traçar políticas para a infância nas quais os espaços culturais contribuam para uma perspectiva de formação estética?

\section{3.}

\section{A dimensão estética do conhecimento em museus e suas relações com o público infantil}

Para Dewey (2010), a experiência estética constitui uma manifestação, registro e celebração da vida de uma civilização. Isso porque, embora ela seja produzida e desfrutada por indivíduos, esses indivíduos são como são, no conteúdo de sua experiência, por causa das culturas da qual participam. Hermann (2010) corrobora com essa perspectiva ao afirmar que o correlato da experiência

\footnotetext{
${ }^{12}$ As informações sobre Educação Infantil na BNCC estão disponíveis em <http://basenacionalcomum.mec.gov.br/abase/\#infantil>. Acesso em: 02 fev. 2018
} 
é a consciência histórica. A experiência estética, ao promover o encontro com a alteridade do outro e do passado, produz seu efeito na formação do indivíduo.

Dewey (2010) considera que existe uma diferença entre o produto artístico (estátua, quadro, música, poesia etc.) e a obra de arte/objeto estético: o produto artístico é físico e potencial e a obra de arte/ o objeto estético é calcada na experiência. A obra de arte ocorre quando um ser humano coopera com o produto artístico de tal modo que o resultado é uma experiência apreciada por propriedades libertadoras e ordeiras. O erro fundamental, entretanto, é a confusão do produto físico com o objeto estético/obra de arte- que é aquilo que é percebido, que existe exatamente na interação onde o indivíduo se constitui na atividade de perceber. O objeto estético é, portanto, percebido por uma série acumulativa de interações que são influenciadas pelo caráter daquilo que se viveu em experiências anteriores. Na experiência estética, o objeto estético opera no sentido de reunir energias que estiveram dispersas (separadas e ocupadas em lidar com muitas coisas diferentes, em distintas ocasiões) e de lhes dar uma organização rítmica particular. A sensação obtida com essa organização, que o autor explica ser comumente reconhecida como esclarecimento, Vigotski (1998) definiu como catarse ${ }^{13}$.

Nessa perspectiva, a arte traz os valores que ficam escondidos na experiência corriqueira por causa do hábito. Martins, Picosque e Guerra (1998) coadunam com essa perspectiva ao afirmar que o objeto estético mostra aos nossos sentidos o pensamento/sentimento das coisas, resgatando a surpresa ao vê-los. Como intérpretes da vida, somos impulsionados pela emoção, nascida do sentimento estético, a estabelecer interpretações e analogias a partir das memórias pessoais e culturais. Por ser metáfora, a obra/o objeto estético não traz uma resposta, mas provoca uma profusão de perguntas que faz extrair novos, diferentes e mais profundos significados do que o olhar contaminado pelo cotidiano vê sobre si mesmo ou sobre as coisas do mundo.

Dewey (2010) considera que para entender o objeto estético (obras e produtos artísticos), é preciso começar por ele em sua forma bruta - nos acontecimentos e cenas que prendem o olhar e o ouvido atentos do indivíduo, despertando seu interesse. Salienta que, historicamente, o pensamento moderno de compartimentalização da vida influenciou um movimento que glorificou as belas-artes em um pedestal distante, afastada da dimensão estética do que é comum na vida comunitária.

${ }^{13}$ Conforme a discussão apresentada no subcapítulo 2.1 
Utensílios domésticos, móveis de tendas e de casas, tapetes, capachos, jarros, potes, arcos ou lanças eram feitos com um primor tão encantado que hoje os caçamos e lhes damos lugar de honra em nossos museus de arte. No entanto, em sua época e lugar, essas coisas eram melhorias dos processos da vida cotidiana. Em vez de serem elevadas a um nicho distinto, elas faziam parte da exibição da perícia, da manifestação da pertença a grupos e clãs, do culto aos deuses, dos banquetes e do jejum, das lutas, das caças e de todas as crises rítmicas que pontuam o fluxo da vida (DEWEY, 2010, p.64-65).

O autor enfatiza como os museus e galerias ilustram algumas das causas que agiram no sentido de segregar a arte, em vez de considerá-la um fator concomitante de outras formas de vida. Objetos que foram úteis e significativos por seu lugar na vida de uma comunidade, nesses espaços, começaram a funcionar isolados de suas condições de origem, servindo para atestar o bom gosto cultural de indivíduos, comunidades e nações. Esclarece que esse movimento agiu no sentido de criar o abismo entre produtor e consumidor (artista e público) e entre a experiência comum e a experiência estética.

Poulot (2013) concorda que a perspectiva de Dewey (2010) está atrelada ao processo constitutivo e, muitas vezes, presente ainda hoje em diferentes instituições museológicas. Contudo, examina que os museus, hoje, podem mobilizar duas molas propulsoras bastante diferentes no que se refere à experiência ocorrida em seus espaços: i) o encantamento diante da obra ou do objeto completamente fora de seu contexto, ou ii) sua exposição em paralelo com saberes e experiências. Na primeira hipótese, reside um dos primeiros modelos de museu, que requeria obras fascinantes, famosas ou singularidades, oferecidas à admiração ou espanto que revelavam significações mais ou menos aguardadas pelo espectador. A segunda hipótese apresenta um modelo conceitual de museu que foi se transformando com o tempo e entende como sua função social a possibilidade de estabelecer ressonâncias, expor objetos que testemunhem referências compartilhadas e induzir conhecimentos suscetíveis de serem ampliados.

Analisando os estudos que versam sobre o processo constitutivo dos museus ao longo da história, corrobora-se com a perspectiva de Dewey (2010) sobre seu caráter supressor da experiência estética. Entretanto, é possível perceber, também, o movimento de transformação dessas instituições a partir da perspectiva apresentada por Poulot (2013). A modificação acerca da compreensão da função social dessas instituições não ocorreu de forma linear. Ainda hoje são encontradas divergências entre os diferentes profissionais que atuam nos espaços museológicos embora os estudos que se preocupam com a 
experiência oferecida aos visitantes nesses espaços venham se ampliando consideravelmente.

Registros históricos comprovam que, entre o século XV e XVI, surgiram os primeiros vestígios de arranjos sistemáticos de objetos raros em gabinetes, caixas, armários e outras mobílias de forma amadora em ambientes domésticos e locais de trabalho de estudiosos. Essas coleções particulares, formadas por peças coletadas, acumuladas e guardadas pelo seu aspecto exótico ou raro, começaram a ser constituídas com o advento da Idade Moderna e as viagens para o Novo Mundo e Oriente, quando alguns nobres europeus começaram a formar seus gabinetes de curiosidades ${ }^{14}$. As coleções eram estruturadas em função de princípios de raridade e novidade, mas também de harmonia e circularidade conforme a representação de mundo que imperava na época. Quanto à sua publicização, os proprietários decidiam quem poderia ter o privilégio de acesso. Geralmente, outros estudiosos, membros da Igreja ou visitas ilustres de locais distantes formavam o restrito público dessas coleções. O contato com o acervo não era sistemático, já que a visitação era restrita e guiada por seus proprietários, seguia uma lógica de prestígio dos convidados ou do interesse do dono em trocas de conhecimento (MORTARA, 2018; MARTINS, 2011).

No final do século XVII, e ao longo do século XVIII, teve início um processo progressivo de abertura dos museus. $O$ acesso às coleções privadas, reais ou não, foi sendo aberto ao público, seja pela ostentação do poderio governamental ou pela promoção do acesso a estudiosos para fins de pesquisa. Martins (2011) considera que esse processo deve ser entendido, em parte, como resultado da pressão de estudiosos amadores, médicos e cientistas pelo acesso às coleções pertencentes aos reis e nobres. Essa estratégia não só contribuiu para abertura de novas instituições como para a valorização dos objetos colecionados por seu valor histórico e científico. Em função dessa demanda por conhecimento, houve uma certa mudança no desenvolvimento das formas expositivas que começaram a seguir princípios mais organizados e taxonômicos. Mortara (2018) também destaca que, nessa época, inúmeras coleções particulares passaram para a tutela do Estado e de universidades e, mesmo parte daquelas que permaneceram sob a propriedade de particulares, abriram suas portas para um público que, embora

\footnotetext{
${ }^{14}$ Os gabinetes de curiosidade, ou câmeras de maravilhas, eram formados por coleções particulares que reuniam o maior número de raridades e espécimes de história natural, animal e humana. $\mathrm{O}$ acervo, em geral, ficava exposto sem critérios de organização, uma vez que o que importava era a quantidade e a qualidade dos objetos. Costumavam compor as coleções: animais, objetos ou obras raras, fabulosas ou insólitas, camafeus, objetos exóticos, fósseis, minérios, múmias, bibelôs, retratos, adereços de cabeça em pena etc. (MACHADO, 2005).
} 
mais amplo, era ainda muito seleto e sujeito à obediência de horários e regras que limitavam o acesso.

Sendo, anteriormente, um espaço destinado à minoria da população que deveria possuir o domínio de saberes que condicionava a compreensão dos objetos expostos, foi na virada do século XIX que o museu começou a se interessar pelas questões da comunicação com o intuito de tornar seu conteúdo acessível a um público heterogêneo, instaurando o princípio educativo dentro das exposições (MACHADO, 2005). Martins (2011) considera que a mudança no pensamento científico vigente modificou a forma como de objetos eram expostos, se antes eram exibidos à exaustão, fez com que fossem realizadas seleções. A exposição dos objetos deveria contar uma história e, para tanto, começaram a ser utilizados dioramas e cenários onde os objetos podiam ser visualizados em contexto parecido ao de seu "ambiente natural". Como resultado dessa nova tendência, a comunicação com o público foi sendo facilitada já que não era mais necessário ser um especialista para compreensão dos arranjos expositivos anteriormente elaborados.

No Brasil, o século XIX ficou conhecido como "a era dos museus brasileiros" (Machado, 2005, p. 139). Foram criadas diversas instituições com coleções que reuniam espécimes e objetos que permitiam mobilizar, classificar e ordenar o mundo. O museu era visto como meio de ensino capaz de divulgar, por meio do discurso expositivo, uma visão iluminista articulando passado, presente e futuro de forma linear. Considerado patrimônio cultural, era o fio condutor de fatos, datas e personagens ilustres da história nacional. Köptcke (2003, p.108) considera que esse museu "ideal do século XIX era um espaço de vulgarização, de difusão e de aculturação, inserido em um esforço geral de modernização da sociedade".

Martins (2011) destaca que essa utilização do museu como espaço de socialização do conhecimento trouxe novas formas de expor as coleções, buscando um contato mais direto com os visitantes. Contudo, esse processo não foi linear. Principalmente na primeira metade do século $X X$, na contramão dos esforços da perspectiva de ampliação do diálogo com diferentes públicos, muitos museus permaneceram com o caráter elitista e dificultado a não especialistas.

Nesse sentido, a segunda metade do século $X X$ foi um período marcante para o campo dos museus em âmbito nacional e internacional. Após a Segunda Guerra Mundial, a Organização das Nações Unidas para a Educação, a Ciência e a Cultura (UNESCO), por meio do Conselho Internacional de Museus (ICOM), criado em 1946, começou a promover diversos encontros para debates e estudos comparativos entre instituições de diversos países, estimulando o 
desenvolvimento e a unificação da área. O ICOM tinha por objetivo efetivar uma cooperação internacional entre os museus. Para tanto, promoveu reuniões, conferências, convênios e estímulo à criação de comitês nacionais com o intuito de ampliar o debate sobre os museus, sua função social e seus públicos entre os profissionais da área (POULOT, 2013).

Fruto desses encontros, a Mesa-Redonda de Santiago do Chile ${ }^{15}$, realizada em 1972, e a Declaração de Quebec $^{16}$, em 1984, trouxeram mudanças significativas acerca do entendimento sobre a função social dos museus, assim como contribuíram para a criação do movimento da Nova Museologia ${ }^{17}$. Antes destinado, prioritariamente, à missão de coletar, conservar e transmitir o patrimônio histórico-artístico-cultural, foi incorporada também a noção de museu como instrumento de desenvolvimento reflexivo. O público, nessa perspectiva, começou a ser percebido enquanto colaborador e criador, pois mais importante do que observar passivamente objetos preservados pelo museu, a Nova Museologia propunha o ato de reflexão e intervenção (MACHADO, 2005).

Buscando também essa contextualização histórica do movimento da Nova Museologia no Brasil, Machado (2005) destaca que esse pensar museal só foi estabelecido no país após o processo de redemocratização, na década de 1980. Nesse momento, começou-se a pensar o ideal de museu a partir do respeito à diversidade cultural, à defesa do patrimônio cultural de minorias étnicas e à integração dos museus às diversas realidades locais.

Segundo a autora, esse movimento trouxe mudanças significativas na relação cotidiana entre os profissionais dos museus, as exposições e seus visitantes. Pelo menos em tese, o foco dos museus e das práticas museais estaria

\footnotetext{
${ }^{15}$ Encontro entre diretores de museus latino-americanos e especialistas de diversas áreas no campo do desenvolvimento gerou a pequena grande revolução que culminou na declaração de Santiago e no conceito do museu integral. No princípio, o impacto da mesa-redonda foi limitado, no entanto, ela passou a ganhar força nas décadas seguintes ao passo que movimentos importantes evocavam (e atualizavam) os princípios de Santiago como referência contemporânea e como referência de um futuro melhor para os museus. Fonte: <www.ibermuseus.org/wpcontent/uploads/2014/09/Publicacion_Mesa_Redonda_VOL_I.pdf>. Acesso em: 28 ago. 2018.

16 Documento fundador do MINOM (Movimento Internacional para uma Nova Museologia), a Declaração de Quebec remete à Mesa-Redonda de Santiago do Chile como suas origens. Dela decorrem: o reconhecimento da necessidade de ampliar a prática museológica e de integrar nessas ações as populações; a convocação ao uso da interdisciplinaridade e de métodos modernos de gestão e comunicação; e a priorização do desenvolvimento social. Fonte: <revistas.ulusofona.pt/index.php/cadernosociomuseologia/article/view/373/282>. Acesso em: 28 ago. 2018.

${ }^{17}$ Movimento que trouxe mudanças significativas na relação cotidiana entre os profissionais dos museus, as exposições e o público. Passou a incorporar a noção de museu como instrumento de desenvolvimento e o público, nessa perspectiva, começou a ser percebido enquanto colaborador e criador. (MACHADO, 2005)
} 
voltado para o diálogo e interação com o público, afim de promover experiências significativas por meio da imersão nas suas diferentes temáticas e linguagens. Reforço o uso da expressão "em tese", porque, mesmo considerando toda essa trajetória de transformação acerca de sua função social, estudos sobre a recepção de públicos em museus ${ }^{18}$ apontam que, ainda que tenham se dedicado a buscar o público como referência para pensar sua prática, por vezes, o que se consolida é uma relação assimétrica que reflete na falta de apropriação desses espaços. Embora medidas como ingressos gratuitos e horários estendidos tentem quebrar os obstáculos para a visitação, existem barreiras (também invisíveis) que continuam dificultando a apropriação desses equipamentos culturais por toda a sociedade (MORTARA, 2018).

Valente (2009) esclarece que redirecionar o foco de atenção para o público levou o museu à produção de novas práticas. Foi preciso ampliar seu campo de ação e multiplicar suas propostas de atuação para buscar acompanhar as demandas por conhecimento da sociedade. Destaca que a relação atual do museu com as demandas da sociedade ainda se confronta com as dificuldades históricas da instituição. Para a autora, os aspectos mais polêmicos estão relacionados à incorporação da atuação junto aos diferentes públicos, ao entendimento de sua dimensão educativa, funções de pesquisa e entretenimento. Esses aspectos conflitantes influenciam diretamente no que tange à concepção das exposições pois, enquanto alguns curadores não consideram sua função educativa, outros consideram essencial.

Na mesma perspectiva, Cury (2007) reconhece que, junto à mudança na compreensão de sua função social, a linguagem expográfica dos museus passou por várias reviravoltas, sendo a mais importante delas a libertação da museologia do objeto. A exposição dos objetos selecionados e organizados de acordo com uma lógica de conhecimento especialista, era implícita e oculta ao público. A autora defende que a superação desse modelo foi essencial porque os objetos não falam por si mesmo e o museu não é um mundo à parte do mundo exterior.

Kramer (1998) considera que os objetos constituem uma singularidade importante nas narrativas históricas dos museus que constroem o passado de diversas maneiras.

Ao caminhar num museu - numa galeria de torsos, ou de outros objetos quaisquer -, o que vemos em cada peça, em cada quadro, em cada obra guardada ali é história condensada, que aglutina contradições, diz e cala, valoriza e omite, conta (KRAMER, 1998, p.205).

${ }^{18}$ Cury (2009), Barbosa (2008), Carvalho (2016), dentre outros. 
Também refletindo sobre a narrativa construída pelos museus, Cury (2007) descreve a exposição como uma linguagem densa e engenhosa (própria e específica dos museus) vinculada ao patrimônio cultural e à conscientização que se deseja possuir - sobre e a partir - dele. Considera a exposição uma linguagem densa porque aglutina valores e atitudes, e engenhosa por ser minuciosamente construída. Para a autora, a densidade e a engenhosidade das exposições dependem de valores, atitudes e harmonização de elementos, não somente para satisfazer as intenções do discurso pretendido (pelos museus), mas, sobretudo, para abrir possibilidades de reflexão e debate sobre as múltiplas formas interpretativas advindas do público.

Contudo, Kramer (1998) questiona a relação que os museus têm estabelecido entre os discursos expositivos e o público: "Existe uma poética nos objetos? O que fazer com os objetos que estão nos museus? Exposições? Para que servem as exposições? Existe uma "linguagem pedagógica das coisas"? Como pensar as diferentes dimensões educativas dos museus?" (KRAMER, 1998, p. 208).

Refletindo sobre a lacuna encontrada, ainda hoje, no potencial comunicativo/educativo dos museus, Cury (2007) esclarece que, ao desvencilhar o foco do objeto para o público e buscando contemplar de maneira mais específica sua dimensão educativa, muitas instituições incorreram no erro de adotar posturas conteudísticas limitantes. Ao tentar dominar os processos de transposição dos saberes específicos de suas coleções para a construção de uma inteligibilidade expográfica, que permitisse a participação cognitiva de diferentes públicos, os museus acabaram subtraindo a possibilidade de proporcionar experiências significativas. Desse modo, até hoje, permanecem condutas museológicas em que o processo expográfico é limitado a: decodificação de um conhecimentorecodificação pelo profissional de museu - decodificação do público. Nesse sentido, Cury (2007) reitera que (de)(re)codificar não alcança o potencial das instituições museológicas.

Entretanto, a autora defende que vem se construindo um novo cenário que aponta para novas e ampliadas possibilidades dos processos expográficos, onde as preocupações da exposição, como meio de comunicação, são deslocadas para as mediações culturais que ocorrem no cotidiano do público visitante. Para a autora, o objetivo das visitas deve ser múltiplo e vinculado a uma experiência, em detrimento de posturas conservadoras que primam pela transmissão de conteúdo. O princípio da ação mediadora deve ser o diálogo que se produz entre o museu e o público e entre a experiência da visita e o cotidiano das pessoas. 
Valente (2009) também ressalta que o movimento dos museus para se adaptar à nova demanda social trouxe essa perspectiva de ver o público como um parceiro na formulação das maneiras de comunicar seu conteúdo. Para a autora, toda exposição tem a intenção de comunicar alguma coisa para o visitante e, além de comunicar, existe a preocupação de estimular a aprendizagem, criando uma atmosfera propícia para este fim. Quando a abordagem de mediação cultural é adotada pelos museus, a comunicação (nela inserida as ações educativas) é moldada por meio de um processo contínuo de negociação que, a partir das experiências dos indivíduos, constroem ativamente seus próprios significados. Cury (2007) enfatiza igualmente a importância da negociação de significados, pois as intenções do museu que realiza a exposição (que são interpretações de determinada temática) se encontram com as interpretações múltiplas dos visitantes. Para a autora, a partir da perspectiva da mediação cultural, não há dicotomia nessa experiência, e sim diálogo e negociação do significado acerca das temáticas em exposição.

Nessa perspectiva, o público é sujeito de sua experiência porque conceitualiza os objetos, gerencia o tempo passado presente futuro, articula memória e identidade. Ao se apropriar da ambiência expositiva e do discurso da exposição, é capaz de reconstruir a retórica e a narrativa, discernir sobre realidade e ilusão, viver a afetividade, elaborar, reelaborar e ressignificar (CURY, 2007).

Examinando essa perspectiva da interação do indivíduo com o ambiente do museu, é possível encontrar elementos que possibilitam plenamente a ocorrência da experiência estética nesses espaços. A ambiência expositiva - lugar de significação, sentidos, percepção e imaginação - é apropriada pelo público e a sua participação criativa se consome. A participação criativa do indivíduo (sua experiência estética) no museu é múltipla e nunca se repete, pois, cada visitante tem sua a percepção dirigida e a ativação do conhecimento prévio articulados de acordo com suas experiências anteriores. Há, portanto, a efetivação da experiência.

No momento em que a ação criativa do visitante se consome, ocorre o que Dewey (2010) definiu como a evocação, reunião e organização particular das energias provindas de experiências anteriores (que antes estavam dispersas e separadas), através da imaginação, por parte daquele que a vive - que se fundam na experiência estética. E Vigotski (1998; 2003) definiu como a catarse (reação específica do sujeito que sofre a experiência estética) - o ato de criação em que o indivíduo, reagindo ao estímulo externo, supera criativamente o seu próprio 
sentimento promovendo a união e a coordenação de uma série de reações internas em uma certa reelaboração criativa do objeto percebido.

Nessa perspectiva, os museus podem ser compreendidos enquanto meio, experimental e criativo, que pode promover a transformação do indivíduo através da interação com a cultura material presente nas exposições. Para Cazelli (2010), a visitação aos museus talvez seja a mais completa experiência multimídia devido à combinação, por exemplo, de arquitetura, textos, objetos, figuras, sons, música e computadores desenhados e articulados, especificamente, para despertar os sentidos e estimular o interesse do visitante. A comunicação museológica busca, portanto, a comunicação de sentidos e revela a complexidade que é o processo de ressignificação da própria dinâmica cultural que se faz na vida cotidiana (CURY,2007).

A interpretação de Chagas e Storino (2007) sobre os espaços museológicas contribui para as reflexões delineadas, até o momento, acerca da dimensão estética do conhecimento que pode ser desenvolvida nessas instituições.

Os museus estão entre os locais que nos proporcionam a mais elevada ideia do homem (...). Eles são janelas, portas e portais; elos poéticos entre a memória e o esquecimento, entre o eu e o outro; elos políticos entre o sim e o não, entre o indivíduo e a sociedade. Tudo o que é humano tem espaço nos museus. Eles são bons para exercitar pensamentos, tocar afetos, estimular ações, inspirações e intuições. Como tecnologias ou ferramentas que articulam múltiplas temporalidades em diferentes cenários sócio-culturais, como territórios que propiciam experiências de estranhamento e familiarização, como entes que devoram e ressignificam o sentido das coisas, os museus operam com memórias e patrimônios e fazem parte das necessidades básicas dos seres humanos. Por este caminho, pode-se compreender que em todo e qualquer museu está presente o gênio humano, a indelével marca da humanidade. Entre os mais diferentes grupos culturais e sociais há uma nítida necessidade e uma notável vontade de memória, de patrimônio e de museu (CHAGAS e STORINO, 2007, p.06).

Apesar de apresentar todas estas possibilidades, o autor destaca que apenas as necessidades e vontades dos grupos sociais não garante, automaticamente, os direitos à memória, ao patrimônio e ao museu. O exercício desse direito de cidadania precisa ser conquistado, afirmado e reafirmado cotidianamente, pois, conforme abordado ao longo desse subcapítulo, a função social dessas instituições nem sempre foi compreendida de forma democrática.

Alguns estudos ${ }^{19}$, na literatura nacional e internacional, reiteram o quanto as práticas e políticas museais, historicamente, reproduziram o sistema de desigualdades preexistente na sociedade, principalmente no que diz respeito ao acolhimento às crianças em seus espaços.

${ }^{19}$ Carvalho (2013), Leite $(2011 ; 2005)$, Reddig (2007), Pol e Asensio (2006), Fallon e Chavepeyer (2013), Shaffer (2015). 
O desconhecimento acerca das especificidades da criança é refletido no despreparo da recepção e na limitação dos educadores (mediadores e professores) para aproveitar as distintas possibilidades da experiência estética a serem exploradas nos espaços museais com as crianças. Essa falta de preparo na formação dos educadores (da escola e do museu) evidencia a lacuna de pesquisas $^{20}$ e a falta de debate nas instituições universitárias, museológicas e escolares sobre a relação do público infantil com os museus, em conformidade com o levantamento bibliográfico exibido no primeiro capítulo (introdução) desta pesquisa.

Conforme mencionado, algumas publicações colaboram na tentativa de compreender alguns aspectos que vem se delineando nessa relação. Esses estudos abordam a potência e os obstáculos que são frequentemente encontrados nas instituições que se propõem a receber crianças. Nas discussões estabelecidas pelos diferentes autores, desenvolvidas sob diferentes prismas, dois aspectos se destacaram, trazendo contribuições para se pensar, no contexto deste estudo, o público infantil nos museus: (i) Democratização dos museus e público infantil e (ii) Dimensão estética e sensibilidade do olhar.

\subsection{1.}

\section{Democratização dos museus e público infantil}

Conforme apresentado, a preocupação com a função social e com as concepções educativas nem sempre acompanhou os espaços museológicos. Todavia, no percurso da história, transformações no entendimento de público provocaram demandas para que os museus se ressignificassem. Esforços no sentido de elaborar estratégias e políticas para a formação de um público mais amplo alterou a função de alguns museus. Nesse momento, os museus passaram a ser compreendidos enquanto instâncias promotoras de transformação social.

Apesar dessa mudança na forma como os museus concebem sua função social, seu reflexo não é totalmente difundido nas práticas museológicas e nem no modo como diferentes públicos percebem essas instituições. Nesse sentido, examinando a função social do museu no que tange aos elementos educativos que o compõe, Kramer e Carvalho (2012) também questionam se, atualmente, esses espaços ainda se preocupam em transpor/transmitir seus conhecimentos ou se têm desenvolvido suas atividades em uma perspectiva que permita a seus visitantes aprender com a cultura e não sobre a cultura.

\footnotetext{
${ }^{20}$ A revisão da literatura internacional de Shaffer (2015) sobre a aprendizagem infantil em museus também evidenciou lacunas de pesquisas.
} 
Para as autoras, espaços de cultura, como museus e centros culturais, podem proporcionar um convite a olhar o mundo de outras formas ao trabalhar com (e estimular) a sensibilidade sobre as temáticas que apresentam. Consideram que a educação que pode ocorrer nesses espaços (compreendida em sua dimensão mais ampla - a formação humana) se dá no sentido que crianças, jovens e adultos devem aprender com a cultura guardada nos museus - fruto da experiência humana acumulada - e não sobre a cultura, em graus hierarquizantes.

A perspectiva teórica de Dewey (1979) contribui para essa reflexão ao elencar as potencialidades de educação quando tratada como o desenvolvimento inteligentemente dirigido de percepção sobre a experiência de vida acumulada pela humanidade:

\begin{abstract}
As realizações do passado constituem o único meio a nosso alcance para compreender o presente. Assim como o indivíduo tem de recorrer à sua própria memória do passado para compreender as condições que individualmente se encontra, assim as questões e problemas da presente vida social estão em íntima e direta conexão com o passado, que os estudantes não podem se preparar para compreender nem os problemas e questões em si mesmos, nem o melhor meio de lidar com eles, sem mergulhar em suas raízes no passado. Em outras palavras, o princípio certo de que os objetivos da aprendizagem estão no futuro e sua matéria imediata está em experiência presente só estará sendo aplicado, na mediada em que a experiência presente seja, por dizê-lo, repuxada para trás. E somente poderá expandir-se pelo futuro se também alargar-se a ponto de incluir o passado (DEWEY, 1979, p. 78-79).
\end{abstract}

Considerando a perspectiva da educação, enquanto formação humana, e dos museus, enquanto espaços educativos que guardam e comunicam os saberes produzidos pela humanidade, possibilita-se a experiência capaz de estimular a emancipação de crianças, jovens e adultos para que queiram conhecer cada vez mais o assunto de diferentes temáticas. As experiências formativas que podem ocorrer nesses espaços fazem parte do processo de construção da cidadania e é direito de todos (KRAMER e CARVALHO, 2012).

Olhando especificamente para as ações a serem realizadas com o público infantil nos museus, entendidos enquanto espaços de formação, Carvalho e Porto (2013) sugerem que, de modo lúdico, os objetos e fenômenos possam ser observados e hipóteses sejam formuladas pelas crianças. Shaffer (2015), ao analisar mundialmente a democratização dos museus para o público infantil, considera que é um processo lento, mas crescente, que vem se delineando a partir de uma corrente teórica ${ }^{21}$ em que "o objetivo é criar experiências interessantes,

21 Os principais teóricos apontados pela autora como referência sobre aprendizagem infantil em museus são John Dewey, Lev Vigotski, Jean Piaget, Maria Montessori, Jerome Bruner e Howard Gardner. 
envolventes, inspiradoras e provocativas" (SHAFFER, 2015, p. 26, tradução da autora).

Leite (2011), que também concebe os museus enquanto espaços de formação marcados pela multiplicidade e pluralidade, aponta alguns aspectos principais ao receber o público infantil em relação à garantia de direitos: a não homogeneização da infância que frequenta esses espaços; a evocação à pluralidade como prerrogativa da cultura; a perspectiva de museus como espaço plural e acolhedor, instigante e democrático; local de experiência e de aprendizado com os objetos e não sobre eles; lócus de partilha e convívio, de descoberta, imaginação e prazer. Para, Oliveira (2011), um aspecto fundante é a ação educativa museológica que contemple a criação imaginadora na relação com as crianças.

Analisando os estudos das autoras, percebe-se a importância de ampliar as discussões sobre as práticas museais a serem desenvolvidas com o público infantil, de modo a garantir o direito de frequentar esses espaços e ter ações planejadas para sua recepção, como os demais públicos. Entretanto, antes de abordar as práticas museológicas a serem desenvolvidas, é preciso questionar se, e como, as crianças têm acesso aos museus e centros culturais.

Buscando então algumas respostas, foi empreendida uma análise das informações disponibilizadas no Guia Brasileiro de Museus (IBRAM, 2011), constatando-se que o território nacional possui um total de 3.118 museus e centros culturais. As regiões Sudeste (1.150), Sul (874) e Nordeste (709) são, nessa ordem, as que apresentam maior quantitativo de museus. No que tange ao Estado do Rio de Janeiro, o Guia informa a existência de 246 museus distribuídos pelos 92 municípios. Destes, 55 possuem museus, outros 37 não têm nenhum espaço cultural cadastrado (tabela 1). E, dentre esses 55 municípios que possuem museus, a cidade do Rio de Janeiro apresenta a maior concentração (tabela 2).

Tabela 1 - Distribuição quantitativa dos municípios do estado do Rio de Janeiro que possuem museus

\begin{tabular}{l|l}
\hline Municípios que não possuem museu & 37 \\
\hline Municípios que possuem museu & 55 \\
\hline Total & 92 \\
\hline
\end{tabular}

Fonte: IBRAM (2011)

Tabela 2 - Municípios do estado do Rio de Janeiro com maior número de museus

\begin{tabular}{l|c}
\hline Rio de Janeiro & 113 \\
\hline Valença & 18 \\
\hline Niterói & 11 \\
\hline Petrópolis & 08 \\
\hline
\end{tabular}

Fonte: IBRAM (2011) 
Constatar que a cidade do Rio de Janeiro apresenta um número mais elevado de museus do que os demais municípios não causa surpresa. Alguns estudos, como o de Machado (2005), destacam que o século XIX ficou conhecido como "a era dos museus brasileiros" (movimento expansivo que diminuiu nas décadas seguintes), e, portanto, o Rio de Janeiro, por ser a capital federal na época, tornou-se sede para muitas instituições.

Contudo, o estudo de Cazelli (2010), realizado no ano de 2003, apontou que a cidade do Rio de Janeiro, apesar de ser um dos mais importantes centros culturais do país, não conseguia dar acesso à cultura de maneira equânime para seus habitantes. No tocante à distribuição de equipamentos culturais (museu, centro cultural, teatro, cinema e biblioteca), constatou-se que quase todos estavam localizados no Centro, São Cristóvão, Zona Sul, Tijuca, Vila Isabel e Barra - áreas de maior poder aquisitivo e capital cultural. A insuficiência e a concentração não equânime do equipamento cultural afetavam, em especial, as pessoas dos setores menos favorecidos do ponto de vista socioeconômico e cultural.

Após quase uma década dos resultados apontados pela autora, examinando o mapeamento das instituições culturais cadastradas nos guias museais do IBRAM (2011) e da Secretaria de Estado de Cultura do Rio de Janeiro (SEC-RJ) (2011), foi possível averiguar que a situação continua análoga. Apesar do número elevado de instituições culturais, a cidade ainda apresenta uma distribuição desigual desses equipamentos. Dos 113 museus da cidade, 38 estão localizados na Zona Sul, 36 na região do centro, 33 na Zona Norte, e apenas 6 na Zona Oeste. Se considerarmos o fato de que a maioria da população reside nas regiões da Zona Norte e Zona Oeste, esse dado mostra uma distribuição desigual das instituições culturais.

Em um estudo piloto ${ }^{22}$ onde tive a oportunidade de investigar, junto ao GEPEMCI (CARVALHO, LOPES e RESINENTTI, 2017), as possibilidades de apropriação dos espaços culturais pelas escolas de Educação Infantil na cidade do Rio de Janeiro, foi possível aferir que a apropriação desses espaços é também dificultada pelo número elevado de crianças matriculadas na rede municipal de

\footnotetext{
22Pesquisa realizada pelo GEPEMCI, no ano de 2013, por meio de questionário online, que buscou conhecer a estrutura, o funcionamento e as ações educativas dos 116 museus e centros culturais da cidade do Rio de Janeiro cadastrados no Guia Brasileiro de Museus (IBRAM, 2011). Apenas 31 instituições responderam ao questionário e, para analisar estatisticamente as respostas, foi construída uma base de dados no software SPSS (Statistical Package for the Social Sciences). Com o retorno da pesquisa, apesar do baixo número de instituições respondentes, foi possível identificar alguns aspectos centrais e esta etapa configurou-se como um estudo piloto da pesquisa.
} 
ensino (mapa 1). Há um grande quantitativo de crianças que frequentam as creches e pré-escolas da rede municipal de educação, principalmente na Zona Oeste da cidade ${ }^{23}$, que precisariam atravessar longas distâncias para acessarem os equipamentos culturais da cidade que participaram do estudo. Desta forma, mesmo possuindo o maior quantitativo de museus no estado, devido às más condições de deslocamento e à desigual distribuição dos equipamentos culturais, o acesso de muitas crianças que frequentam a Educação Infantil no município do Rio de Janeiro é dificultado.

\section{Figura 1: Distribuição de museus participantes da pesquisa e alunos matriculados no segmento de Educação Infantil da SME-RJ}

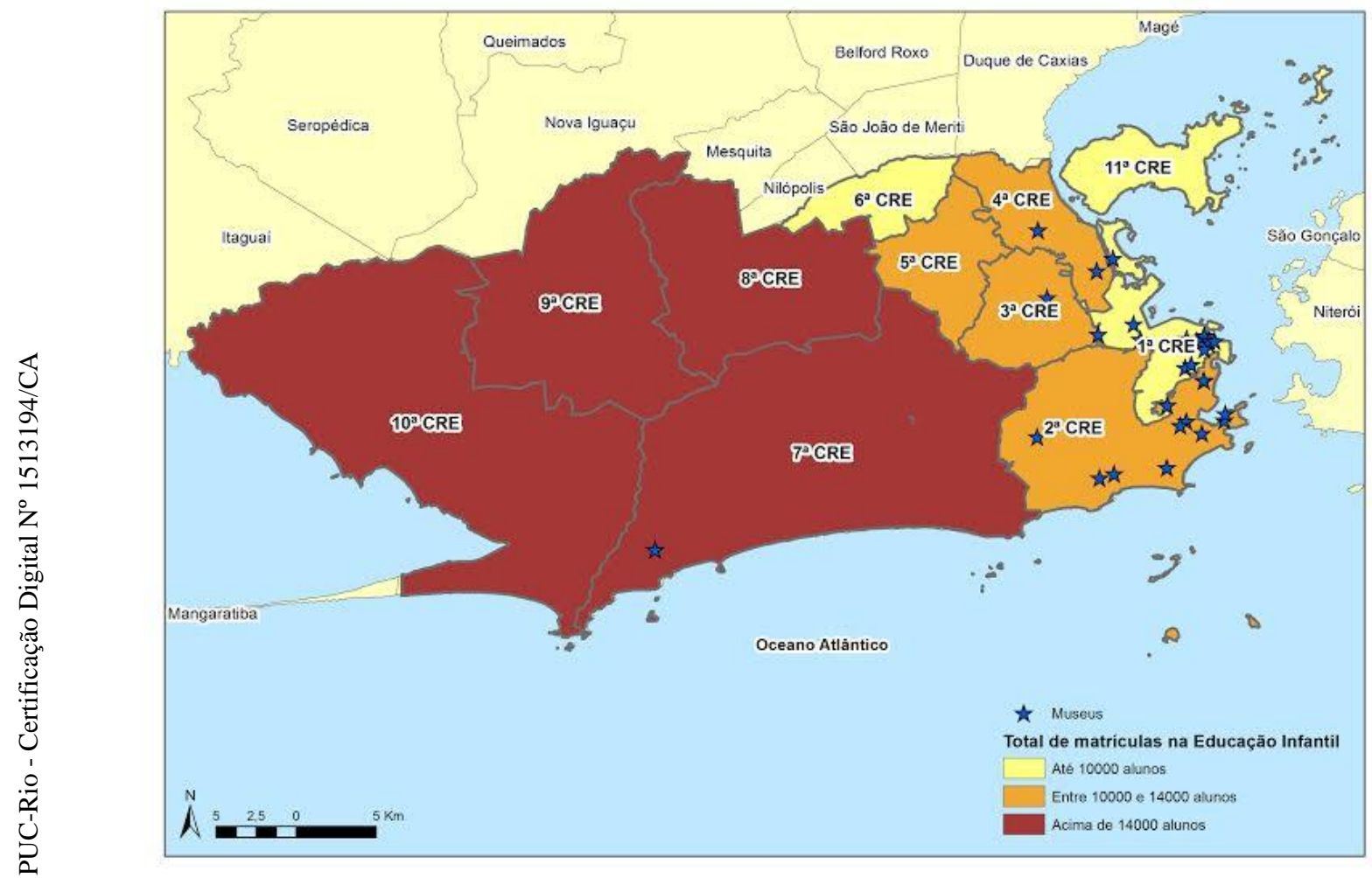

Fonte: Carvalho, Lopes e Resinentti (2017)

Os resultados obtidos com esse estudo piloto apontaram, além da desigual distribuição dos equipamentos culturais em âmbito municipal, a pouca atenção dada às condições do trabalho a ser desenvolvido com o público infantili24. Há, portanto, um público em potencial desconsiderado desde o acesso até à falta de programação para esse segmento nos museus e centros culturais da cidade. Logo, a melhoria na distribuição dos equipamentos culturais e o avanço nas condições e oferta de programação para o público infantil nos espaços culturais é

${ }^{23}$ As 7 $7^{a}$, 8 8 $^{\text {a }}$ e 10 $0^{\text {a }}$ Coordenadorias Regionais de Educação (CRE), que possuem o maior quantitativo de crianças matriculadas, ficam localizadas na região da Zona Oeste da cidade (Barra da Tijuca, Bangu, Campo Grande, Santa Cruz e Jacarepaguá).

24 Ver mais em Carvalho, Lopes e Resinentti (2017). 
uma tarefa necessária para reconhecer as crianças como cidadãs de direito, e as instituições culturais como espaços democráticos (CARVALHO, LOPES e RESINENTTI, 2017).

Mesmo considerando essa má distribuição do acesso à cultura em território nacional, Moura (2011) ressalta que os museus podem contribuir para uma redefinição desse panorama cultural no país. A autora concebe os espaços museológicos como possíveis cenários de disseminação e socialização do patrimônio cultural e artístico e como espaço de encontro e de debate, em que a dimensão criativa e produtiva pode ser incorporada em substituição à dimensão reprodutiva "na qual apenas o que já foi produzido e legitimado é comunicado" (MOURA, 2011, p.106-107).Conforme destaca Poulot (2013), desde que teve suas estruturas fundantes voltadas à democratização, o maior desafio dos museus consiste em manter sempre viva uma contribuição para a fisionomia cultural de cada região, em vez de inscrever seu projeto em uma simples arqueologia de colecionismo. Para tanto, não basta apenas a democratização do acesso aos museus, mas também uma distribuição mais equânime desses espaços e escolha cuidadosa sobre seu conteúdo, sobre o que deve ser preservado.

Nesse sentido, Carvalho e Porto (2013) esclarecem que investir em democratização efetiva dos museus para os visitantes consiste na criação de oportunidades para que todos compartilhem seus espaços de forma a favorecer uma troca de experiências - não hierárquica - da cultura.

\subsection{2.}

\section{Dimensão estética e sensibilidade do olhar}

Para Kramer e Carvalho (2012), a experiência de crianças, jovens e adultos nos diversos espaços culturais pode contribuir no sentido de sensibilizar o olhar e propiciar situações de aprendizado do ponto de vista cultural, político, ético e estético. Os museus detêm potencial para estimular os indivíduos na construção desse olhar sensível, que busca ver de outra maneira, contemplar outros ângulos e interpretar novos sentidos nas relações que ocorreram historicamente entre natureza, seres humanos e suas invenções. Desse modo, a contemplação, que busca a compreensão, envolve conhecimento, experiência estética, agir ético e estético, pois "ser contemplador significa não sucumbir à vida cotidiana no mundo contemporâneo e sua enxurrada de imagens, fatos, ruídos, choques, sustos que provocam reações, reflexos, rebates, constrição" (KRAMER e CARVALHO, 2012, p. 26).

O trabalho museológico de coletar o acervo, pesquisar para conhecê-lo, preservá-lo, selecionar o que será mostrado ao público e escolher 
expograficamente as formas de contar sua história, possibilita que velhos e novos sentidos sejam encontrados e construídos por seus visitantes.

Fallon e Chavepeyer (2013) consideram que conhecer os museus, desde a mais tenra infância, é uma maneira de ampliar a capacidade de escolha na sociedade de hoje, que se encontra imersa em imagens e cercada de representações, muitas delas impostas. No encontro com suas obras e artefatos, os museus convidam a perceber, sentir e construir referências sobre o que se vê, unindo a experiência individual ao que é social. As referências povoam o imaginário, unem o indivíduo à história, a outros seres humanos, a outras culturas e à história da humanidade.

Devemos visitar museus como se estivéssemos visitando parentes ou amigos. Os
artistas cujos trabalhos estão expostos compartilham conosco um momento de suas
vidas, um testemunho de seu tempo, seu ponto de vista sobre a realidade (...).
Durante a visita, podemos sentir interesse, espanto, diversão, estranheza, raiva ou
podemos ficar entediados. E, de repente, quando entramos em uma sala, nos
sentimos excitados e subitamente movidos por um detalhe ou pelo conjunto de uma
obra. Nos sentimos unidos, reconhecidos, próximos àquele artista que expressa
nossa própria intimidade tão bem. Esse trabalho será parte para sempre do nosso
"museu interior", das nossas referências(...). Devemos permitir às crianças o
treinamento inicial de seu "museu interior". Eles estão famintos por imagens, por
representações, eles amam reconhecer o mundo que eles descobrem (FALLON e
CHAVEPEYER, 2013, p.8-9, tradução da autora). Leite (2011) concorda que museus podem ser espaços de significação, encantamento e produção de conhecimento, espaços privilegiados para a pesquisa, salvaguarda e comunicação da natureza e da cultura. Essas instituições podem se tornar locais de experiência onde acervos variados, oferecidos à fruição, incitem o campo da imaginação e, consequentemente, os processos de criação. No que tange à recepção ao público infantil, a autora considera que é importante levar esse público aos espaços museológicos, mas além da apreciação deve-se buscar uma experiência estética significativa, onde a criança possa relacionar aquilo que vê com o que já conhece de seu cotidiano. Contudo, muitas vezes, o lugar destinado às crianças nos espaços culturais ainda é o de espectadora distante e não de contempladora ativa.

Frequentar exposições amplia o repertório imagético - sonoro, visual, corporal (...) é parte de sua formação, sendo assim, antes de tudo, um direito. A criança, assim como seus pais, colegas ou educadores, faz parte da história da humanidade e, como tal, também escreve e se inscreve na história coletiva. Ela vive a realidade, transforma-a e é por ela transformada. Para tal, é necessário que possa trocar, dialogar, questionar aquilo que vê (LEITE, 2005, p. 51).

Compreendendo a criança enquanto sujeito que vive seus processos, sua história, em tempos e lugares distintos, Reddig (2007) também destaca a importância de garantir que toda criança tenha acesso aos espaços, que possibilitem conhecer e interagir com sua cultura, buscando aprender, sonhar, 
imaginar e criar. Refletindo sobre imaginação e processos criativos nos museus, Oliveira (2011) compreende que as instituições museológicas são, ou deveriam ser, espaços profícuos para a educação cultural das crianças e para o fortalecimento e expansão da imaginação infantil. Para a autora, museus podem ser espaços repletos de novidades para crianças, e imagens e objetos que podem provocar intensas emoções nas crianças (propulsores de uma imaginação criadora), não se restringem aos novos inventos tecnológicos da sociedade. "Tal arrebatamento do olhar, do corpo sensível, também ocorre na experiência das crianças com o velho, com as imagens do passado" (OLIVEIRA, 2011, p. 319), o que para a criança é novo.

Sobre a atividade criadora da imaginação, Vigotski (2009) ressalta que esta depende diretamente da riqueza e da diversidade de experiências anteriores. Essas experiências constituem o material com que se criam as condições da fantasia ${ }^{25}$. Portanto, quanto mais rica a experiência do indivíduo, mais material estará disponível para sua imaginação e possibilidades de criação. "Eis por que a imaginação da criança é mais pobre que a do adulto, o que se explica pela maior pobreza de sua experiência" (VIGOTSKI, 2009, p.22).

Nesse sentido, museus podem ser concebidos enquanto espaços profícuos para enriquecer as crianças de experiência, de forma que sejam estimuladas a expandirem sua imaginação. Por guardar e expor de forma diferenciada os diferentes testemunhos da cultura material, podem provocar curiosidade, admiração, encantamento, estranhamento, discordância - dentre tantos outros sentimentos - de modo a impulsionar a criança a desvendar o sentido dos objetos, com uma postura crítica e investigativa perante as coisas do mundo.

Refletindo sobre a curiosidade das crianças e sua forma de conhecer e organizar o mundo, Benjamin (2017, p.107) observa que "toda pedra que ela encontra, toda flor colhida e toda borboleta capturada já é para ela o começo de uma coleção e tudo aquilo que possui constitui para ela uma única coleção". E o mundo está repleto de objetos que são alvo da atenção e da ação das crianças. O autor considera que crianças são especialmente inclinadas a buscar os locais de trabalho onde a atuação sobre as coisas se processa de maneira visível, pois, nos seus detritos, é possível conhecer o mundo. Com esses produtos residuais

\footnotetext{
${ }^{25} \mathrm{~A}$ psicologia denomina de imaginação ou fantasia a atividade criadora baseada na capacidade de combinação do cérebro. Comumente designa-se como fantasia ou imaginação tudo que não é real e não pode ter um significado prático sério. Entretanto, na verdade, a imaginação é base de toda atividade criadora e manifesta-se em todos os campos da vida cultural tornando possível toda criação humana seja ela artística, científica ou técnica. Logo, todo o mundo da cultura é também produto da imaginação e fantasia que resulta na criação humana. (VIGOTSKI, 2009).
} 
criam brincadeiras em que estabelecem, entre os mais diferentes materiais, uma relação nova e incoerente de apropriação do mundo.

Nessa busca das crianças pela apreensão e compreensão do mundo, Leite (2011) destaca a qualidade estética diferenciada que os museus podem oferecer nesse contexto. Olhando mais de perto as obras e objetos que compõem o acervo - que expograficamente têm dimensões que não cabem nas páginas dos livros as crianças (e os diversos públicos) podem perceber aspectos de forma diferenciada, mais sensível e atenta. Encontrando objetos do cotidiano ou de outras épocas (ou representações deles), sob uma nova organização estética e numa outra relação (delineada pelo discurso expositivo), pode-se deparar com o desconhecido bem como estranhar o que é familiar.

Richter (2011) concorda com a perspectiva de Dewey (2010) sobre o entendimento de objeto estético (seja ele um quadro, uma música, uma poesia, um objeto musealizado etc.) enquanto produção humana, fruto de uma atividade intencional da consciência, ao apropriar-se simbolicamente dos elementos sensíveis da matéria. Para a autora, o objeto estético permite que a criança vá desvelando as possibilidades do mundo em toda sua riqueza e diversidade. Ao imaginar, isto é, ao criar suas primeiras ficções sobre aquele objeto, a criança prepara-se para dialogar consigo e com sua cultura. Interferindo e modificando, ativamente, é afetada e modificada em sua forma intensa de entender e interpretar as coisas, as pessoas e as relações em seu meio cultural.

Nessa perspectiva, Kramer e Carvalho (2012) consideram que "sensibilizarse e construir outro olhar é parte de um processo humano e humanizador ímpar que constitui as relações afetivas entre as pessoas." (KRAMER e CARVALHO, 2012, p. 26). Compreende-se, portanto, que a constituição de si, desde a infância, é construída a partir das relações afetivas com o outro. Por meio da relação com o diferente é possível criar ou desconstruir nossos alicerces, hipóteses e modelos e é desta forma que se constitui o indivíduo: a partir da relação sensível com o coletivo, com o outro.

Partindo dos diferentes acervos colecionados e selecionados que contam e mostram distintos estilos de vida, maneiras de pensar, sentir e falar, os museus podem contribuir para a essa formação sensível. Por meio da experiência com essas diferentes temáticas museais, a criança pode ser estimulada a entrar na dinâmica de alteridade/identidade que ajuda na construção da percepção de si como sujeito de cultura.

Hermann (2010) assinala que a estética se mostra hábil na experiência da alteridade, evidenciando, naquilo que é estranho, uma liberdade do sensível 
contra o embrutecimento da percepção automatizada. Para a autora, as experiências estéticas são constitutivas do saber e da construção de realidade devido à capacidade humana de ficcionar. Desta forma, falar de estética, hoje, é falar de possibilidades para trazer à tona a imaginação em um agenciamento dos sentidos que pode produzir novas modelagens, compreensões e percepções que incitam à pluralidade.

No que cabe aos museus, para potencializar essa experiência de qualidade estética diferenciada, Gabre (2016) destaca três aspectos principais que não podem ser desconsiderados ao receber esse público: que a percepção do mundo para as crianças pequenas se dá pelos sentidos, o reconhecimento da capacidade de interpretação das crianças e a possibilidade da experiência sensível. 


\section{3 \\ Os museus da cidade do Rio de Janeiro e o público de Educação Infantil}

\section{1. \\ Metodologia da pesquisa}

Considerando que a pesquisa teve como objetivo conhecer a relação entre o público de Educação Infantil e museus de diferentes tipologias da cidade do Rio de Janeiro, buscando compreender quais aspectos possibilitam ou dificultam esse encontro, a abordagem qualitativa mostrou-se a mais adequada. Seu ajustamento metodológico reside no fato de ser um meio de produção de conhecimento que não busca mensurar e medir, mas sim compreender e buscar explicações para valores e significados de um meio social.

Segundo Goldenberg (2009), os pesquisadores que optam pelo desenvolvimento de pesquisas qualitativas buscam investigar causas, relações, mudanças e possíveis consequências de um fenômeno estudado sobre a vida humana, tentando captar sua essência. Nesse sentido, a presente pesquisa foi desenvolvida sob a ótica qualitativa, com o intuito de investigar a relação entre crianças da Educação Infantil e museus com o objetivo de contribuir para o conhecimento acerca dos aspectos que possibilitam e dificultam a experiência dos diferentes agentes envolvidos (crianças - educadores do museu - professores).

Alicerçando-me nos estudos de Flick (2009), foi possível perceber que a preocupação nas pesquisas qualitativas centra-se em levantar os elementos que possam contribuir para a compreensão e explicação do que se está investigando e, nesse processo, "as subjetividades do pesquisador e daqueles que estão sendo estudados são parte do processo de pesquisa" (Flick, 2009, p. 22). Reconhecer a não neutralidade do pesquisador, isto é, considerar que no processo de pesquisa a subjetividade fez parte do processo de investigação, implica reconhecer que os dados coletados e analisados são também descritivos, pois a compreensão do processo que ocorre quando as crianças vão aos museus com suas escolas foi mais importante do que possíveis produtos.

Freitas (2003), também considera uma característica importante da pesquisa qualitativa que o investigador assuma seu papel; entretanto, salienta como aspecto igualmente necessário compreender os participantes da pesquisa 
enquanto sujeitos possuidores "de uma voz reveladora da capacidade de construir um conhecimento sobre a realidade" (Freitas, 2003, p. 29). Nesse sentido, ter uma escuta atenta para as crianças, para os professores e para os profissionais das instituições museológicas foi o aspecto fundamental que norteou a pesquisa nos caminhos metodológicos escolhidos. Para tanto, um dos desafios da pesquisa consistiu em encontrar procedimentos metodológicos adequados às especificidades do público infantil, dos educadores dos museus e dos professores, sujeitos dessa relação, bem como compreender as especificidades desses sujeitos no espaço museológico, lócus da pesquisa.

Sobre a escolha dos procedimentos metodológicos que viabilizam as pesquisas qualitativas, Brandão (2010) considera que, se a pesquisa pretende compreender a complexidade de um fenômeno social, é imprópria qualquer ortodoxia metodológica por parte do pesquisador. Compreendendo que não existe uma única metodologia correta e sim uma opção adequada para cada problema que precisa ser estudado, a autora ressalta a importância de se combinar diferentes angulações do mesmo objeto. Corroborando essa perspectiva, AlvesMazzoti e Gewandsznajder (1998) destacam que as pesquisas qualitativas são caracteristicamente multimetodológicas, isto é, usam uma variedade de procedimentos e instrumentos de coleta de dados com o intuito de obter mais informações que contribuam para a análise dos dados.

Partilhando dos apontamentos indicados pelos autores sobre aspectos importantes a serem ponderados no uso da abordagem qualitativa para o desenvolvimento de uma pesquisa, ao definir os caminhos metodológicos que melhor conduziriam para desvendar as questões e alcançar os objetivos propostos na tese, ao longo do processo, quatro recursos metodológicos foram desenvolvidos e utilizados: (i) Base de Dados do GEPEMCI; (ii) Observação de campo - das visitas realizadas por escolas de E.I aos museus selecionados para investigação; (iii) Entrevistas individuais e coletivas - com os responsáveis dos setores educativos dos museus, com os mediadores e com professores; (iv) Análise documental - documentos oficiais, internos ou disponíveis na web sobre a proposta de ações oferecidas ao público de E.I nos museus investigados.

\section{a) Base de Dados GEPEMCI:}

Conforme destacado no capítulo 1 (introdução), o interesse por esse tema de pesquisa teve início não só no exercício da atividade docente, mas também nas considerações sinalizadas pela banca examinadora ao término do mestrado e no ingresso no Grupo de Pesquisa em Museu, Cultura e Infância (GEPEMCI). 
Os dados iniciais para o desenvolvimento da tese foram obtidos no ano de 2015, junto à coleta e construção de uma Base de Dados produzida pelo GEPEMCI. A pesquisa do Grupo teve como objetivo mapear e conhecer os setores educativos de museus e centros culturais da cidade do Rio de Janeiro com o intuito de identificar as atividades oferecidas ao público - e mais especificamente às crianças de 0 a 6 anos -, a estrutura de funcionamento mantida pelas instituições, os agentes sociais que neles atuavam e, principalmente, as estratégias pedagógicas desenvolvidas nesses espaços, em diálogo, portanto, com esta pesquisa de doutorado.

Os primeiros achados da investigação desenvolvida no GEPEMCI revelaram que, dos 85 museus e centros culturais da cidade do Rio de Janeiro que participaram da pesquisa, trinta ${ }^{26}$ afirmaram possuir programação específica para turmas de Educação Infantil ${ }^{27}$. A análise da Base de Dados do GEPEMCI permitiu compreender alguns aspectos da realidade atual da recepção ao público infantil nos museus e centros culturais do município ${ }^{28}$. Contudo, para atender as demandas da investigação era preciso avançar para a etapa seguinte do estudo, com a realização de uma pesquisa de campo.

Para a delimitação do trabalho de campo, buscando abarcar uma amostra dos museus da cidade que incluíam o público de Educação Infantil em suas programações, a investigação foi realizada em um museu de cada tipologia (arte, ciência, história e museu comunitário) desse universo de 30 instituições. A partir de contato telefônico, foram selecionados quatro museus que apresentaram maior profusão de possibilidades para a investigação: Museu de Arte do Rio, Casa da Ciência da UFRJ, Museu Casa de Rui Barbosa e Museu da Maré (respectivamente arte, ciência, história e museu comunitário). Os critérios que nortearam a escolha dessas instituições foram: oferta de programação específica para turmas de Educação Infantil no ano de 2017 e maior frequência do público infantil escolar. Entretanto, não foi possível realizar as observações no Museu da Maré na época de efetivação do campo. A pesquisa no local foi inviabilizada devido ao contexto

\footnotetext{
${ }^{26}$ Gráfico 3 - Número de museus da cidade do Rio de Janeiro que possuem ou não programação específica paras as escolas de Educação Infantil.

27 A listagem das instituições que afirmaram possuir programação específica para escolas de educação infantil, no ano de 2015, consta nos apêndices da tese.

${ }^{28}$ Elucidado no próximo subcapítulo "3.2 Quando os pequenos cariocas visitam os museus e centros culturais da cidade com a escola”.
} 
de violência que tomou o entorno da comunidade ao longo do ano, reduzindo para três o número de instituições investigadas ${ }^{29}$.

Além dos dados quantitativos que apresentam um mapeamento geral da recepção ao público infantil nos museus da cidade, apresentados no subcapítulo a seguir, algumas informações sobre os três museus selecionados para a observação em campo foram extraídas da Base de Dados do GEPEMCl:

- Nome da instituição;

- Tipologia;

- Responsável pelas ações educativas na instituição;

- Para quais audiências a instituição oferece programações específicas;

- Qual a frequência de visitas das crianças à instituição (0-3, 4-5, 6-10 anos);

- Com quem o público infantil visita a instituição (escola, família, outros);

- Formação dos profissionais que atuam com o público infantil nos museus;

- Quais itens a instituição disponibiliza para crianças de 0-5 anos;

- Em quais espaços é realizado o trabalho com as crianças de 0 a 5 anos;

- Quais as atividades oferecidas às crianças (0 a 3, 4 a 5 e 6 a 10 anos);

- Se a instituição considera que deveria ocorrer alguma mudança no trabalho realizado junto ao público infantil.

\section{b) Observação de campo}

Para Moura e Ferreira (2005), a observação - técnica para coletar informações e registros - é útil não somente para a obtenção de informações das questões de pesquisa, mas também ao desenvolvimento de hipóteses a serem testadas em estudos futuro, devido à profusão de dados que se pode obter em campo. As autoras destacam que uma das críticas frequentemente dirigidas às técnicas de observação é que estão ainda mais sujeitas a erros provenientes de interpretações subjetivas das situações na medida em que o pesquisador se apoia exclusivamente em suas próprias observações. Nesse sentido, Moura e Ferreira (2005) consideram fundamental que sejam adotados alguns procedimentos em campo, como, por exemplo, realizar uma descrição clara dos objetivos da pesquisa e das categorias que compõem o sistema de observação.

Ghedin e Franco (2011) também sugerem que o trabalho de campo deve ser constituído por um conjunto explícito de ações que orientem os procedimentos da pesquisa a ser realizada em determinado contexto com o objetivo de compreender o objeto de investigação. Destacam que o trabalho de campo é a forma mais utilizada atualmente pelos investigadores que optam pelo método qualitativo para recolher os dados de pesquisa. Contudo, os

${ }^{29}$ O Museu de Favela, única alternativa de museu comunitário da cidade que, assim como o Museu da Maré, respondeu à pesquisa informando que possuía programação para o público de Educação Infantil, comunicou que não estava recebendo demanda desse público e não havia previsão de agendamentos para o primeiro semestre de 2017. 
autores fazem ressalvas para que o pesquisador tenha claro que o trabalho de campo implica a ação de "estar dentro do mundo do sujeito: não como uma pessoa que sabe de tudo, mas quer aprender; não como uma pessoa que quer ser como o sujeito, mas como alguém que procura saber o que é ser como ele" (Ghedin e Franco, 2011, p. 193-194). Portanto, é preciso que o pesquisador adote a postura de admitir o ponto de vista do grupo pesquisado com respeito, empatia e a maior inserção possível.

Elencando os desafios encontrados nas pesquisas com crianças que utilizam como recurso metodológico a observação, Oliveira (2002) salienta que gestos, movimentos, danças, imaginação, falas, brincadeiras, sorrisos, caretas, choros, apegos, desapegos, e outras tantas formas de se expressar, são importantes para que se possa de fato captar, compreender e perceber o que as crianças têm a dizer.

Refletindo sobre o desafio ético e metodológico elucidado pelos autores supracitados sobre a técnica de observação em pesquisas e, principalmente, considerando as especificidades das pesquisas com crianças (no que tange a observar, escutar, perceber e olhar como as crianças reagem à experiência com o museu, com os professores e com os mediadores), considerei apropriado o desenvolvimento de um roteiro para a observação em campo. 0 roteiro de observação (apêndice 5) foi estruturado em cinco categorias: I tópicos a serem observados nas crianças, II - tópicos a serem observados nos educadores dos museus, III - tópicos a serem observados nas atividades realizadas; IV- tópicos a serem observados nos professores e IV- tópicos a serem observados no espaço expositivo.

A primeira categoria, com foco nas crianças, teve como objetivo observar o que as crianças expressavam durante a visita; o que despertou maior interesse; interpretações e articulações com os objetos; atitudes das crianças a partir da mediação com outras crianças/com os adultos/com o espaço do museu.

A categoria destinada à observação dos mediadores buscou conhecer a relações estabelecidas com as crianças por esses profissionais; as estratégias utilizadas para atuar junto às crianças; se estimulavam o posicionamento crítico desse público; se davam oportunidades para que as crianças expressassem suas ideias; se favoreciam a interação social da criança com seus pares/com adultos/com o espaço do museu.

No que concerne à categoria de realização das atividades, foi observado se havia materiais e linguagens de apoio; as ações implementadas e as metodologias utilizadas no momento da visita. Em relação aos professores, buscou-se captar 
como se relacionavam durante a visita com as crianças, com os educadores do museu e com o conteúdo/espaço da exposição. E a categoria destinada aos espaços expositivos teve como foco a observação dos locais onde foram realizadas as visitas: a disposição do acervo; possibilidades de mobilidade/autonomia/brincadeiras; os aparatos e dispositivos oferecidos.

\section{c) Entrevistas:}

Seguindo o caminho metodológico em que busquei promover uma escuta atenta dos sujeitos envolvidos na pesquisa (crianças, professores e profissionais dos setores educativos), com a observação de campo das crianças nos museus, constatei que era necessário compreender o ponto de vista dos responsáveis pela realização desses eventos. Para obter essas informações, desenvolvi três roteiros distintos de entrevistas individuais e coletivas $^{30}$ destinados aos professores, aos mediadores e aos responsáveis pelos setores educativos das instituições investigadas.

Brandão (2010) considera que a entrevista é um trabalho que exige a atenção permanente do pesquisador aos seus objetivos, que o obriga a escutar e refletir sobre a forma e o conteúdo da fala dos entrevistados. Na condução dessa atividade, a autora salienta ser fundamental a triangulação entre empatia, engajamento mútuo (pesquisador e pesquisado) e objeto da pesquisa. Portanto, antes de cada entrevista, tive o cuidado de apresentar-me como pesquisadora, explicitando o tema da pesquisa, justificando sua relevância e garantindo a devolutiva dos resultados.

Para Moura e Ferreira (2005, p. 65), "as entrevistas podem ser classificadas em estruturada, inestruturada e semi-estruturadas". Buscando alcançar os objetivos pretendidos com a pesquisa, optei pelas entrevistas semiestruturadas ${ }^{31}$, a partir de um roteiro preliminar de perguntas que se moldaram à situação concreta no momento de realização das entrevistas. Desta forma, tive a possibilidade de formular novas questões quando julguei importante aprofundar pontos considerados relevantes para o estudo.

Duarte (2002) destaca que o uso das entrevistas semiestruturadas constitui uma opção teórico-metodológica que está no centro de vários debates entre pesquisadores das ciências sociais. Em geral, os estudiosos apontam problemas

\footnotetext{
30 Os três roteiros de entrevista constam nos apêndices da tese.

${ }^{31}$ As entrevistas realizadas na pesquisa se enquadram na categoria semiestruturada, definida pelas autoras, por terem como objetivo contribuir para a construção do objeto, na medida em que, além de ajudar a aprofundar as informações obtidas na Base de Dados do GEPEMCI, permitiram focalizar as condições observadas em campo.
} 
ligados à postura adotada pelo pesquisador em situações de contato, o seu grau de familiaridade com o referencial teórico-metodológico escolhido e, sobretudo, à leitura, interpretação e análise do material recolhido no trabalho de campo. Para evitar esses equívocos é necessária a adoção de alguns cuidados, como planejamento prévio, estudos teórico-metodológicos, testes e reelaboração dos materiais.

Moura e Ferreira (2005) também salientam a importância de o pesquisador elaborar com cuidado todos os momentos da entrevista: (i) preparação - para definir o que se deseja avaliar e fazer um roteiro; (ii) início - fazendo uma breve apresentação de si e de seus objetivos permitindo ao entrevistado também se apresentar; (iii) percurso - deve conduzir a entrevista especificando e clarificando os diferentes tópicos a serem abordados por meio de perguntas abertas e fechadas, e (iv) término - é recomendável que faça um resumo das informações obtidas de forma a esclarecer qualquer ponto que tenha ficado confuso e, em seguida, agradecer a colaboração do entrevistado e informá-lo sobre a disponibilização dos resultados. Ainda pontuando os cuidados necessários no momento da entrevista, Duarte (2002) alerta que muitos problemas podem ser identificados quando o pesquisador retira esse instrumento do papel (ou do computador) e ganha significado na interação entrevistador/entrevistado.

$\mathrm{Na}$ tentativa de adotar esses cuidados, desenvolvi três roteiros de entrevista distintos destinados aos sujeitos da pesquisa (professores, mediadores e coordenadores dos setores educativos). Os roteiros foram construídos com o objetivo de articular o que se pretendia saber e passaram por fases de construção, teste e reconstrução para que se pudesse avaliar se atendiam aos objetivos da investigação. $O$ anonimato foi garantido a todos os entrevistados, que puderam escolher um nome fictício.

\section{- Entrevista com professor}

As entrevistas com os professores que visitaram os três museus investigados com suas turmas de E.I foram realizadas individualmente e tiveram como objetivo saber: (i) se os professores tinham o hábito de frequentar museus em momentos que não estivessem circunscritos à sua prática, (ii) os motivos para a realização da visita, (iii) se consideraram a proposta educativa do museu relevante para as crianças, (iv) se costumavam frequentar museus com suas turmas de E.I, (v) se possuíam preferência por algum tipo específico de museu para visitar com suas turmas, (vi) se em sua formação docente houve algum estímulo para que frequentassem esses espaços, e (vii) como percebiam a relação entre museus e escolas de E.I. 
A realização das entrevistas ocorreu no final das visitas com, pelo menos, um professor de cada escola que visitou as instituições investigadas. Tendo em vista o reduzido tempo entre o término das atividades nos museus e o retorno para as escolas, assim como a atenção demandada quando o grupo possuía uma quantidade elevada de crianças para poucos educadores responsáveis, as entrevistas foram concisas buscando em poucas questões captar as informações essenciais.

\section{- Entrevista com mediadores}

As entrevistas com os mediadores dos museus investigados foram realizadas coletivamente e tiveram como objetivo identificar: (i) aspectos considerados importantes no trabalho de mediação com o público de E.I; (ii) as propostas de mediação para esse público; (iii) possíveis dificuldades no trabalho de mediação com esse público; (iv) a oferta (ou não) de formação específica do museu para a receber o público infantil; (v) se consideravam que as crianças de 0 a 6 anos conseguiam estabelecer alguma relação com o conteúdo das exposições; (vi) se avaliavam que a visita ao museu traria algum benefício para as crianças; (vii) a relação estabelecida com os professores de E.I que visitavam o museu com suas turmas; (viii) se consideravam necessária alguma modificação no trabalho realizado com as turmas de E.I.

\section{- Entrevista com coordenadores dos setores educativos}

As entrevistas com os responsáveis pelo setor educativo dos museus investigados, realizadas individualmente, buscaram aprofundar as informações obtidas na Base de Dados do GEPEMCI e compreender como essas instituições percebiam o público infantil em seus espaços. Para alcançar esse objetivo, e visando a organização dos conteúdos, a entrevista foi estruturada em três módulos: I - setor educativo e recursos humanos, II - público infantil e III atividades realizadas.

A categoria I abordou aspectos do setor educativo da instituição: se existia; quando se estruturou; como era a estrutura física desse setor; quantidade, formação e divisão de trabalho de seus profissionais; possíveis dificuldades na relação entre o museu e as escolas de Educação Infantil.

A categoria II, que teve como foco a percepção sobre o público infantil, buscava saber dos coordenadores quando teve início o programa destinado a esse público; que profissionais/setores participavam da elaboração dos programas educativos; que profissionais/setores realizavam as ações educativas; se existia alguma formação específica para a equipe receber o público infantil; se as exposições eram concebidas pensando a inclusão das crianças ou ocorria 
algum trabalho de adaptação para a realização das visitas; se contribuíam de alguma forma para a divulgação do conhecimento acerca do público infantil em museus; se identificavam algum obstáculo/dificuldade no trabalho realizado; se consideravam que as crianças de 0 a 6 anos conseguiam estabelecer alguma relação com o conteúdo das exposições; se avaliavam que a visita aos museus poderia trazer benefícios para crianças dessa faixa etária; se consideravam necessária alguma modificação no trabalho realizado.

A última categoria, destinada à investigação das atividades oferecidas ao segmento de Educação Infantil, buscou identificar programas/projetos educativos desenvolvidos especificamente para esse público; aspectos da exposição que eram priorizados nas visitas; em quais espaços era realizado o trabalho; o que a instituição pretendia provocar com o trabalho desenvolvido; se existia alguma avaliação do trabalho realizado; encontros/cursos com os professores desse segmento; reformulações nas atividades oferecidas; divulgação das ações educativas do museu para as escolas.

\section{d) Análise Documental}

A análise dos documentos fornecidos pelos museus investigados foi a última etapa metodológica da pesquisa durante a realização do campo. A partir de uma reunião com os coordenadores dos setores educativos, solicitei que disponibilizassem material com informação sobre a instituição e, mais especificamente, sobre ações educativas. Essa etapa possibilitou cotejar alguns dados obtidos na Base de Dados do GEPEMCI, na entrevista com os coordenadores dos setores educativos dos museus e na observação de campo.

A partir do desenvolvimento e implementação desses quatro recursos metodológicos, a etapa posterior da pesquisa consistiu na triangulação dos dados obtidos, conforme exposto abaixo (quadro 2), para melhor alcançar os objetivos da pesquisa. Flick (2009) destaca que a triangulação em pesquisas qualitativas é importante pois proporciona a articulação de diversos métodos qualitativos e quantitativos dando-Ihes igual relevância e superando as limitações de um método único. 
Quadro 2 - Triangulação dos recursos metodológicos

\begin{tabular}{|c|c|c|}
\hline QUESTÃO & OBJETIVO & $\begin{array}{c}\text { RECURSO } \\
\text { METODOLÓGICO }\end{array}$ \\
\hline $\begin{array}{l}\text { Como os museus e } \\
\text { centros culturais } \\
\text { investigados recebem o } \\
\text { público de Educação } \\
\text { Infantil? }\end{array}$ & $\begin{array}{l}\text { Analisar o modo como as } \\
\text { instituições museais se } \\
\text { preparam } \\
\text { (espaço/equipe/ações) para } \\
\text { receber crianças em visitas } \\
\text { escolares }\end{array}$ & $\begin{array}{l}\text { - Base de Dados } \\
\text { GEPEMCI } \\
\text { - Observação de campo } \\
\text { - Análise documental } \\
\text { - Entrevista com } \\
\text { responsável do setor } \\
\text { educativo } \\
\text { - Entrevista com } \\
\text { mediadores }\end{array}$ \\
\hline $\begin{array}{l}\text { Qual a relação } \\
\text { estabelecida pelos } \\
\text { museus com o público } \\
\text { infantil? }\end{array}$ & $\begin{array}{l}\text { Identificar a relação } \\
\text { estabelecida pelos museus } \\
\text { com o público infantil - o } \\
\text { que os profissionais falam } \\
\text { sobre o público infantil e as } \\
\text { constatações observadas } \\
\text { na prática. }\end{array}$ & $\begin{array}{l}\text { - Observação de campo } \\
\text { - Entrevista com o } \\
\text { responsável pelo setor } \\
\text { educativo dos museus } \\
\text { - Entrevista com } \\
\text { mediadores } \\
\text { - Análise documental }\end{array}$ \\
\hline $\begin{array}{l}\text { Como as crianças reagem } \\
\text { à experiência museal de } \\
\text { diferentes temáticas? }\end{array}$ & $\begin{array}{l}\text { Perceber como as crianças } \\
\text { reagem à experiência } \\
\text { museal - expectativas, } \\
\text { formas como se expressam, } \\
\text { conhecimentos e } \\
\text { interpretações que } \\
\text { conseguem articular. }\end{array}$ & - Observação de campo \\
\hline $\begin{array}{l}\text { Como os professores de } \\
\text { E.I se relacionam com as } \\
\text { práticas educativas dos } \\
\text { museus e centros } \\
\text { culturais? }\end{array}$ & $\begin{array}{l}\text { Compreender as relações } \\
\text { estabelecidas pelos } \\
\text { professores de E.I que } \\
\text { impulsionam a prática de } \\
\text { levar suas turmas aos } \\
\text { museus e centros culturais; }\end{array}$ & $\begin{array}{l}\text { - Entrevista com } \\
\text { professores } \\
\text { - Observação de campo }\end{array}$ \\
\hline $\begin{array}{l}\text { Existe articulação entre } \\
\text { museus e escolas de } \\
\text { Educação Infantil? }\end{array}$ & $\begin{array}{l}\text { Verificar se existem } \\
\text { aspectos que dificultam ou } \\
\text { facilitam a relação entre } \\
\text { museus e escolas de } \\
\text { Educação Infantil. }\end{array}$ & $\begin{array}{l}\text { - Entrevista com } \\
\text { professores } \\
\text { - Entrevista com setores } \\
\text { educativos dos museus } \\
\text { - Entrevista com } \\
\text { mediadores } \\
\text { - Observação de campo } \\
\text { - Análise Documental }\end{array}$ \\
\hline
\end{tabular}

Fonte: Dados da Pesquisa

Conforme explicitado na tabela 3 e no quadro 3, durante os sete meses de realização do campo $^{32}$, foram feitas 12 observações ${ }^{33}$ nos três museus

\footnotetext{
${ }^{32}$ Os preparativos para entrada em campo começaram em março de 2017 (início do ano letivo nas escolas), quando foi possível entrar em contato com alguns museus cadastrados na Base do GEPEMCl e obter a informação se estavam recebendo agendamentos e se teriam programação para o público de E.I naquele ano. Após obter as informações necessárias, selecionar as instituições que participariam da pesquisa, reunir a documentação exigida e obter as devidas autorizações, iniciei o campo em maio e permaneci até dezembro de 2017 (período do recesso escolar).

${ }^{33}$ No Museu Casa de Rui Barbosa foi realizada apenas uma observação porque só ocorreu uma visita de E.I na instituição no período de realização do campo. Apesar de uma única observação, sua relevância para a pesquisa decorre de sua representatividade no campo dos museus históricos (primeiro Museu Casa brasileiro), da preocupação e implementação de ações educativas que se fez
} 
selecionados. Participaram da pesquisa 329 crianças e 14 professores. Em relação aos educadores dos museus, foram entrevistados 7 mediadores $^{34}$ e 3 coordenadoras dos setores educativos, que possuíam denominações diferentes para o cargo. Todos os dados coletados na Base de Dados do GEPEMCI e na pesquisa de campo foram sistematizados no software Atlas Ti e, posteriormente, analisados.

Tabela 3 - Quantitativo da pesquisa de campo

\begin{tabular}{|c|c|c|c|c|c|}
\hline Instituição & Observações & Crianças & $\begin{array}{c}\text { Professores } \\
\text { Entrevistados }\end{array}$ & $\begin{array}{c}\text { Mediadores } \\
\text { Entrevistados }\end{array}$ & $\begin{array}{c}\text { Coordenadoras } \\
\text { dos Setores } \\
\text { Educativos } \\
\text { Entrevistadas }\end{array}$ \\
\hline $\begin{array}{c}\text { Casa da } \\
\text { Ciência da } \\
\text { UFRJ }\end{array}$ & 4 & 73 & 4 & 3 & 1 \\
\hline $\begin{array}{c}\text { Museu } \\
\text { Casa de } \\
\text { Rui } \\
\text { Barbosa }\end{array}$ & 1 & 27 & 1 & 1 & 1 \\
\hline $\begin{array}{c}\text { Museu de } \\
\text { Arte do Rio }\end{array}$ & 7 & 229 & 9 & 3 & 1 \\
\hline $\begin{array}{c}\text { Total } \\
\text { Fonte: }\end{array}$ & 12 & 329 & 14 & 7 & 3 \\
\hline
\end{tabular}

Quadro 3 - Perfil dos entrevistados

\begin{tabular}{|l|l|l|l|l|}
\hline \multicolumn{2}{|c|}{ Nome fictício } & \multicolumn{1}{c|}{ Instituição } & \multicolumn{1}{c|}{ Função } & \multicolumn{1}{c|}{ Formação } \\
\hline 1 & Carla & Escola pública municipal & Professora & Pedagogia \\
\hline 2 & Maria & Escola pública municipal & Professora & Pedagogia \\
\hline 3 & Gisele & Escola pública municipal & Professora & Pedagogia \\
\hline 4 & Tatiane & Escola pública municipal & Professora & Pedagogia \\
\hline 5 & Ariane & Escola pública municipal & Professora & Pedagogia \\
\hline 6 & Mário & Escola pública municipal & Professor & Pedagogia \\
\hline 7 & Conceição & Escola pública municipal & Professora & Pedagogia \\
\hline 8 & Fabiana & Escola pública municipal & Professora & Pedagogia \\
\hline 9 & Leona & Escola pública federal & Professora & Pedagogia \\
\hline 10 & Liliane & Escola particular & Professora & Pedagogia \\
\hline 11 & Andreza & Escola particular & Professora & Pedagogia \\
\hline 12 & Célia & Escola particular & Professora & Pedagogia \\
\hline 13 & Jane & Escola particular & Professora & Pedagogia \\
\hline 14 & Adriele & Escola particular & Professora & Pedagogia \\
\hline 15 & Francisca & Museu Casa de Rui Barbosa & $\begin{array}{l}\text { Museóloga/ } \\
\text { Tecnologista }\end{array}$ & Museologia \\
\hline 16 & Paula & Casa da Ciência da UFRJ & $\begin{array}{l}\text { Chefe da Seção } \\
\text { de Educação }\end{array}$ & Pedagogia \\
\hline 17 & Clarisse & Museu de Arte do Rio & $\begin{array}{l}\text { Educadora de } \\
\text { Projetos }\end{array}$ & Cinema \\
\hline 18 & Andrea & Casa da Ciência da UFRJ & Mediadora & $\begin{array}{l}\text { Graduanda em } \\
\text { Biologia }\end{array}$ \\
\hline
\end{tabular}

presente historicamente na instituição e da profusão de dados obtidos na observação e nas entrevistas.

${ }^{34}$ No momento de realização do campo, o Museu Casa de Rui Barbosa possuía apenas uma mediadora atuando na instituição. 


\begin{tabular}{|c|l|l|l|l|}
\hline \multicolumn{2}{|c|}{ Nome fictício } & \multicolumn{1}{c|}{ Instituição } & \multicolumn{1}{c|}{ Função } & \multicolumn{1}{c|}{ Formação } \\
\hline 19 & Carol & Casa da Ciência da UFRJ & Mediadora & $\begin{array}{l}\text { Graduanda em } \\
\text { Educação } \\
\text { Artística }\end{array}$ \\
\hline 20 & John & Casa da Ciência da UFRJ & Mediador & $\begin{array}{l}\text { Graduando em } \\
\text { Conservação e } \\
\text { Restauro }\end{array}$ \\
\hline 21 & Maria Luiza & Museu Casa de Rui Barbosa & Mediadora & $\begin{array}{l}\text { Graduanda em } \\
\text { Museologia em em }\end{array}$ \\
\hline 22 & Enzo & Museu de Arte do Rio & Mediador & $\begin{array}{l}\text { Graduando } \\
\text { Artes Visuais em }\end{array}$ \\
\hline 23 & Abel & Museu de Arte do Rio & Mediador & $\begin{array}{l}\text { Graduando } \\
\text { Artes Visuais }\end{array}$ \\
\hline 24 & Maximiliano & Museu de Arte do Rio & Mediador & História \\
\hline
\end{tabular}

Fonte: Dados da Pesquisa

\section{2. \\ Quando os pequenos cariocas visitam os museus e centros culturais da cidade}

A partir do diálogo teórico sobre a dimensão estética da experiência na infância, que pode ter íntima implicação com os espaços museológicos, abordado no segundo capítulo desta tese, foi importante buscar a empiria para compreender como ocorre, atualmente, essa relação. Os museus e centros culturais recebem o público infantil? Como? Em quais espaços? Que atividades oferecem?

Conforme mencionado no subcapítulo anterior, na tentativa de responder a essas questões (com um recorte para o município do Rio de Janeiro), no ano de 2015 tive a oportunidade de participar da pesquisa desenvolvida pelo GEPEMCI que investigou as ações dos setores educativos de museus e centros culturais da cidade.

A partir do envio de questionário online a todos os 139 museus e centros culturais cadastrados no Guia de Museus Brasileiros - (IBRAM, 2011) e na publicação Museus RJ - Um guia de Memórias e Afetividades (SEC-RJ, 2013) foi possível constatar que a cidade contava efetivamente com 99 espaços em funcionamento ${ }^{35}$. Dentro desse universo, 85 participaram da pesquisa e 13, apesar de estarem em funcionamento, após inúmeros contatos, não foi obtida resposta.

As questões direcionadas especificamente às ações destinadas ao público infantil buscavam desvendar a frequência deste público, quais instituições da cidade ofereciam programação para crianças de 0 a 6 anos, quem levava as

\footnotetext{
${ }^{35}$ Foi constatado, no período de aplicação dos questionários, que 11 espaços não se consideravam museus; 12 instituições estavam desativadas sem previsão de reabertura; 3 estavam fechadas em decorrência de obras na cidade do Rio de Janeiro pela realização dos Jogos Olímpicos de 2016; 4 ainda estavam em fase de implementação; 6 estavam temporariamente fechadas para reformas e 4 instituições, apesar de se apresentarem de modo autônomo nos guias, declararam possuir a mesma gestão administrativa e uma única resposta para as informações buscadas.
} 
crianças a esses espaços, as iniciativas realizadas para atrair esse público, os itens e espaços disponibilizados, as atividades oferecidas e a formação dos profissionais que atuam com as crianças.

Tendo em vista que $85 \%$ dos museus e centros culturais da cidade do Rio de Janeiro participaram da pesquisa, considerei possível e pertinente traçar um panorama das ações oferecidas às crianças que visitam os espaços museológicos no município.

Um dos primeiros dados que o mapeamento realizado apontou foi a frequência reduzida do público infantil nas instituições culturais (gráfico 1). Em um universo de 85 museus, 31 afirmaram que a frequência de crianças entre 0 a 3 anos era inexistente, 23 consideram que a frequência de crianças entre 4 a 5 anos era baixa e a frequência de crianças entre 6 a 10 anos era considerada média em 31 espaços.

Gráfico 1: Número de museus da cidade do Rio de Janeiro em função da frequência do público infantil por faixa etária

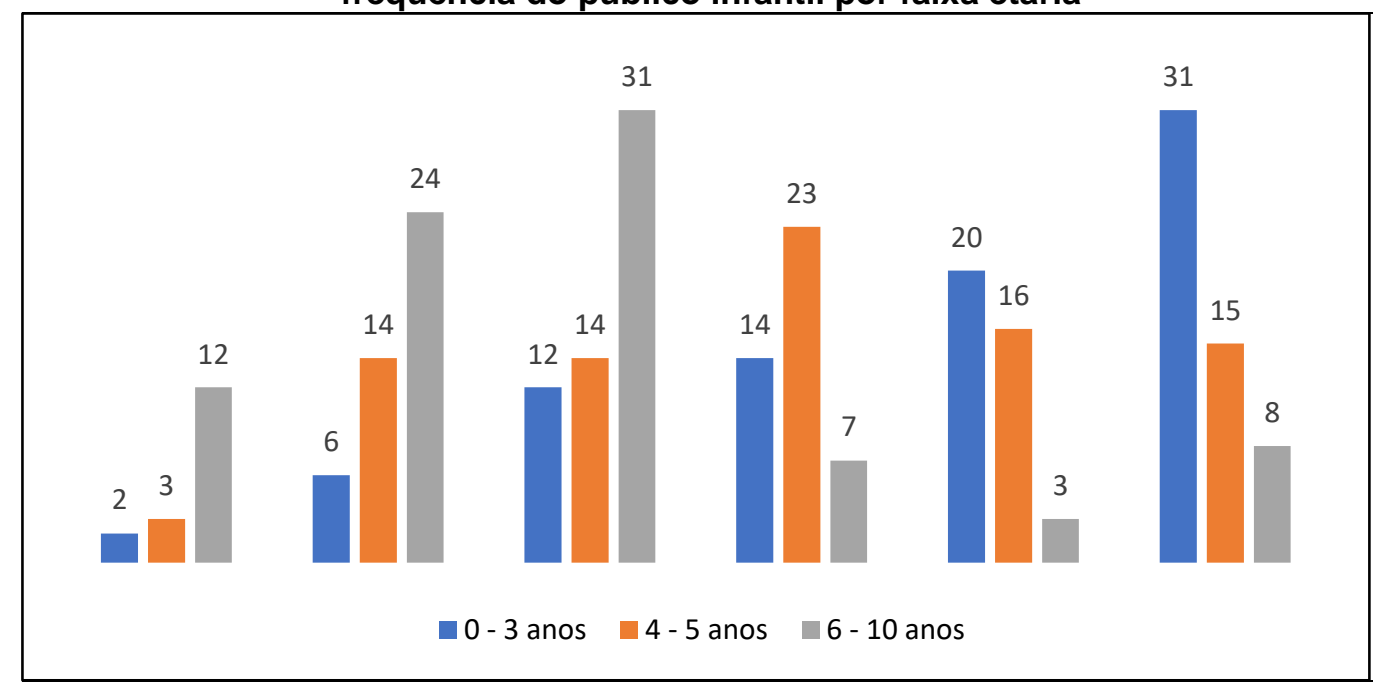

CARVALHO et al. (2015)

Mesmo considerando a frequência reduzida, quando questionados sobre com quem as crianças visitam esses espaços, foi evidenciado o papel das escolas na promoção do encontro entre crianças e espaços culturais (gráfico 2). Das 85 instituições que responderam ao questionário, 48 afirmaram que o público infantil frequentava o museu em visitas escolares e 27 declararam que as visitas ocorriam em família, e quatro instituições afirmaram que as crianças eram acompanhadas de outros responsáveis (grupos de igreja, catequistas, grupos de escoteiros, amigos etc.). Seis museus assinalaram a opção "não se aplica", sinalizando que o espaço não era visitado pelo público infantil. 
Gráfico 2: Número de museus da cidade do Rio de Janeiro por tipo de acompanhante do público infantil

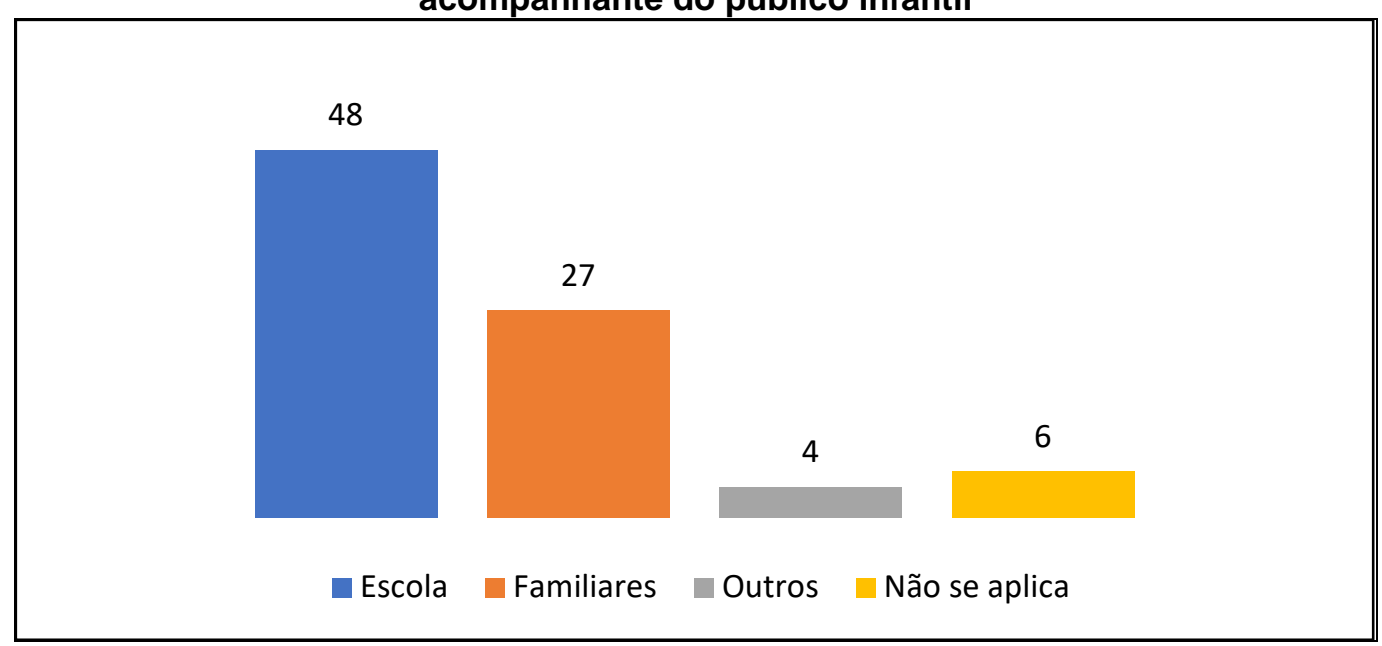

Fonte: CARVALHO et al. (2015)

Mesmo a escola sendo o principal agente promotor do encontro entre crianças e instituições museológicas, a oferta de programação para a Educação Infantil nos museus e centros culturais da cidade é reduzida. No gráfico 3 , é possível constatar que a maior parte das instituições não possui programação específica para esse público. Dos 30 museus que possuem, o número é reduzido para 13 no que se refere ao seguimento creche (turmas com crianças de 0 a 3 anos).

Conforme sinalizam Cazelli (2010) e Carvalho (2016), as visitas escolares constituem o grande público dos museus no Brasil. É, portanto, intrigante o fato de as escolas de Educação Infantil ainda serem pouco contempladas nas programações das instituições museológicas considerando que, desde o ano de 2009, o ensino pré-escolar (4 a 5 anos de idade) da E.I tornou-se obrigatório, assim como os demais segmentos da educação básica. Diante desse fato, cabe questionar se os museus da cidade percebem as crianças da Educação Infantil como um público escolar em potencial. 
Gráfico 3: Número de museus da cidade do Rio de Janeiro que possuem ou não programação específica paras as escolas de Educação Infantil

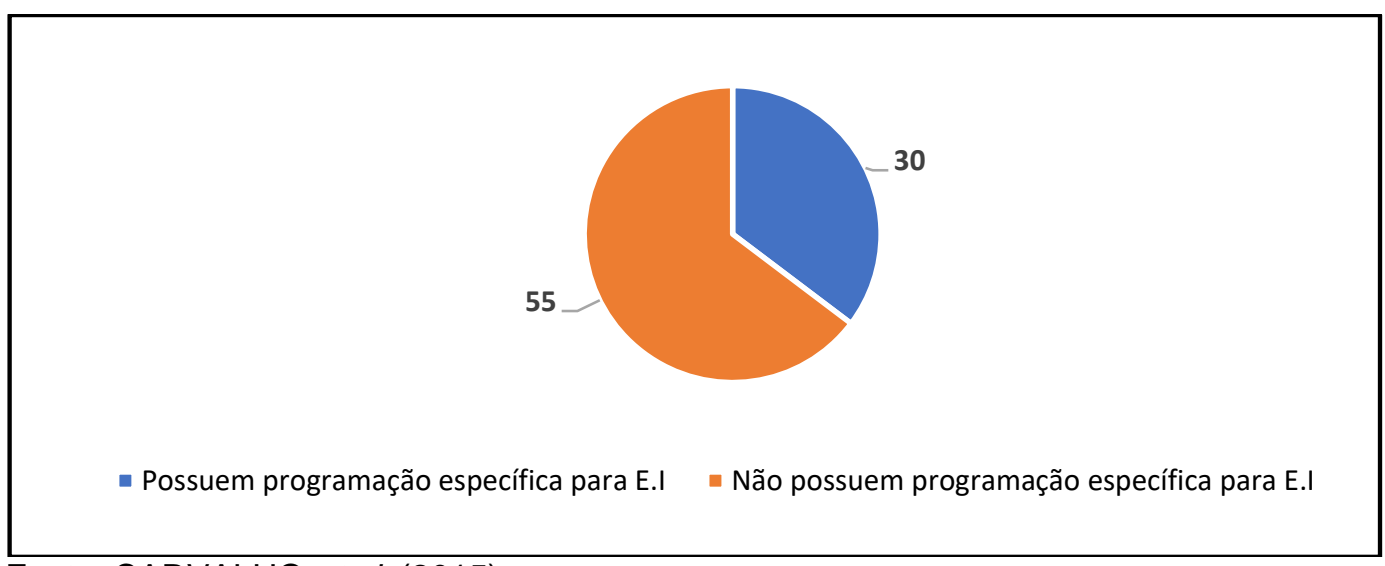

Fonte: CARVALHO et al. (2015)

Refletindo sobre a relação ainda pouco estabelecida entre Educação Infantil e museus, e examinando o papel da escola nessa relação, Carvalho (2013) destaca que, ao abordar professores do segmento infantil que visitavam o espaço cultural onde realizou sua pesquisa, foi recorrente a declaração que as escolas trabalhavam com a realização de projetos que, em geral, não se relacionavam com as temáticas das exposições. "Ou seja, as instituições de Educação Infantil compareciam a eventos que tivessem relação com a temática abordada" (Carvalho, 2013, p. 11). No caso das grandes exposições, as visitas ocorriam, em sua maioria, devido à forte divulgação na mídia ou por exigência das famílias. Nesse sentido, a autora questiona se os profissionais da Educação Infantil não têm esvaziado a potencialidade dos museus e subestimado a capacidade das crianças. Para a autora, os aspectos constatados em sua pesquisa apontam que as instituições de E.I deveriam rever o uso que têm feito dos espaços museológicos. Para além da preocupação com os conteúdos curriculares, a experiência que se deseja oportunizar às crianças, o planejamento das ações empreendidas e a compreensão que as propostas educativas dos museus não estão, necessariamente, atreladas às abordagens escolares são aspectos a serem priorizados quando escola e professores decidem visitar os museus com suas turmas.

O fato de as escolas condicionarem suas visitas aos museus mediante uma relação estreita com os conteúdos trabalhados ao longo do ano letivo pode estar diretamente relacionado a outro aspecto investigado na pesquisa do Grupo: quais são os museus, em suas tipologias, que mais e menos oferecem programação específica para o público de Educação Infantil? O senso comum sobre os "saberes 
pertinentes" às crianças influencia na oferta das ações educativas desenvolvidas pelos museus?

Os museus apresentam uma variedade de tipologias ${ }^{36}$, mas, dentre as 85 instituições que participaram da pesquisa do GEPEMCI, pode-se perceber a predominância dos museus históricos como as instituições que menos oferecem programação específica para esse segmento (gráfico 4). E, nas 30 instituições que afirmaram possuir programação específica para as escolas de Educação Infantil, prevalecem os museus de arte (gráfico 5).

Gráfico 4: Número de museus da cidade do Rio de Janeiro que não possuem programação específica para o público de Educação Infantil por tipologia de museu

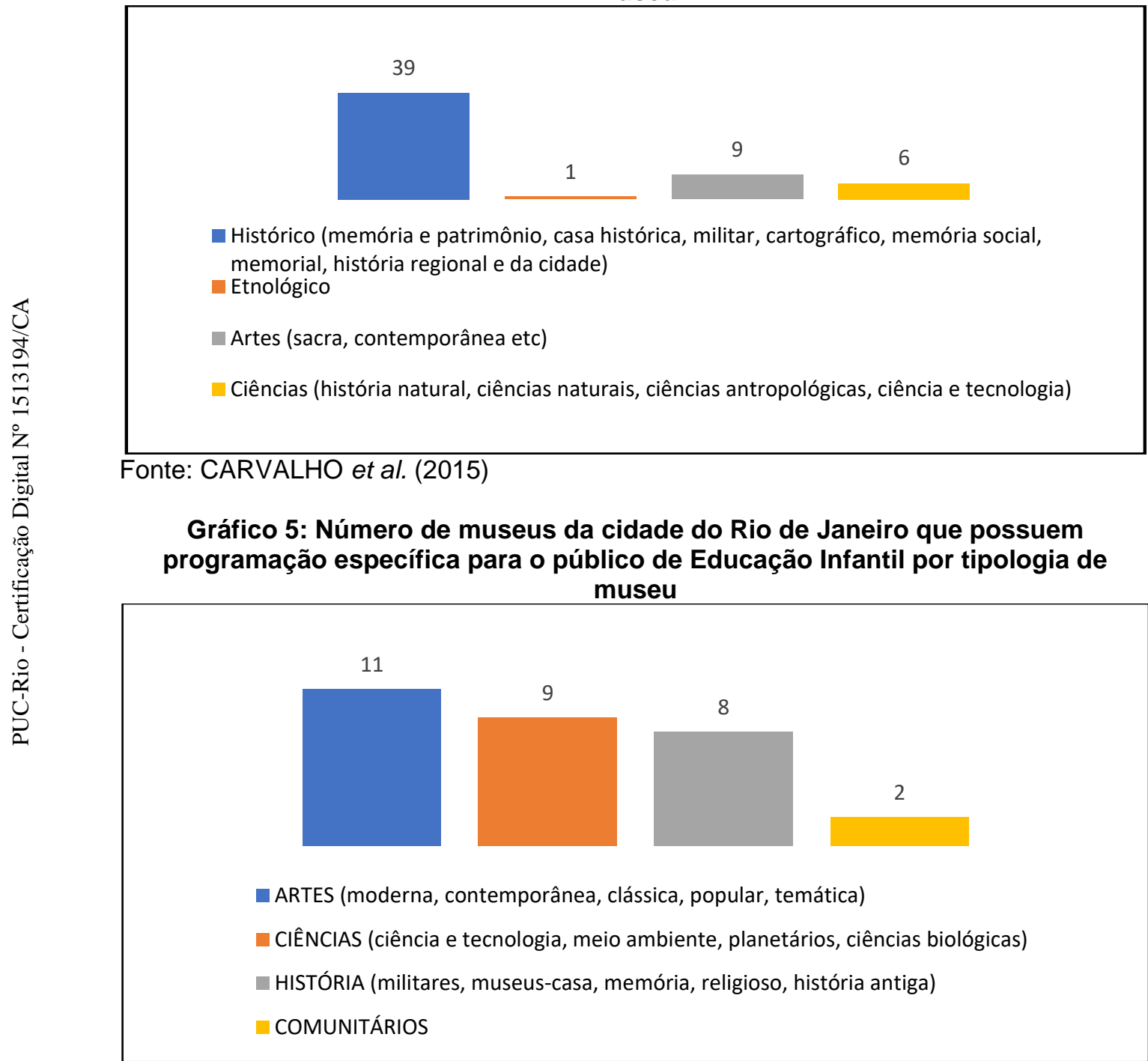

Fonte: CARVALHO et al. (2015)

${ }^{36}$ Tipologias segundo o Guia dos Museus Brasileiros (IBRAM, 2011): antropologia e etnografia, artes visuais (nesta categoria também incluem-se as chamadas artes aplicadas - aquelas que são voltadas para a produção de objetos, tais como porcelana, cristais, prataria, mobiliário, tapeçaria etc.), ciências naturais e história natural, ciência e tecnologia, imagem e som, virtual, biblioteconômico, documental e arquivístico (IBRAM, 2011, p. 19-20). 
Conforme explicitado no levantamento bibliográfico apresentado no capítulo 1 (introdução), as poucas pesquisas que se dedicaram a investigar a relação das crianças da Educação Infantil em visita aos espaços museológicos concentramse, em sua maioria, em museus de arte. A relação potente que pode ser estabelecida entre arte e infância nos diferentes espaços culturais é alvo de vários estudos e não me atentarei a essa discussão no momento ${ }^{37}$. A produção de conhecimento sobre o público infantil em museus de ciência também vem crescendo, principalmente sobre a audiência espontânea (crianças que visitam os museus com suas famílias). Entretanto, a investigação em museus de outras tipologias, principalmente nos museus históricos, ainda é escassa - seja sobre audiência programada (escolar) ou espontânea.

Observando o gráfico $6^{38}$ é possível perceber que os 30 museus e centros culturais que afirmaram possuir programação específica para as visitas escolares para E.I também declararam desenvolver diferentes atividades para esse público. Constatar essa variedade de atividades é um aspecto positivo; todavia, é preciso indagar se essas iniciativas se relacionam com a temática do museu ou são desvinculadas da proposta.

Conforme destacado por Leite (2005), alguns museus buscam criar iniciativas para atrair o público infantil e atividades como teatro, dança, filme e brincadeiras são comumente utilizadas nessa tarefa. Nesse sentido, a autora questiona se é preciso criar "iscas" ou "disfarces" para que as crianças se interessem pelos espaços culturais, como se o acervo e a exposição não fossem suficientemente atrativos. Nesse sentido, após a reflexão teórica em que se constatou com os estudos de Benjamin (2015) e Dewey (2002), que a criança se sente extremamente atraída pelo material da experiência humana (conteúdo dos museus), a necessidade de buscar atividades mirabolantes em suas programações, evidencia que muitas instituições culturais ainda desconhecem as especificidades desse público. Desta forma, o papel comunicativo do museu, no que tange à linguagem das exposições, ao acervo e às temáticas, deveria ser o foco central para as crianças e para outros públicos.

Outrossim, diferentes atividades que são criadas com intuito de atrair o público infantil, desde que não sejam empobrecidas da temática central que

\footnotetext{
${ }^{37} \mathrm{~A}$ discussão teórica específica sobre a relação entre crianças da educação infantil e museus de arte foi desenvolvida em minha dissertação de mestrado: LOPES, Thamiris Bastos. O Público Infantil no Museu Internacional de Arte Naîf do Brasil. Dissertação (Mestrado) - Programa de PósGraduação em Museologia e Patrimônio, UNIRIO/MAST, Rio de Janeiro, 2014.

${ }^{38} \mathrm{Na}$ opção de resposta a essas questões, era possível assinalar mais de uma alternativa, portanto, há número de respostas superior à 30 .
} 
permeia o museu, podem ser utilizadas positivamente de forma a contribuir para um repertório diverso de experiências nesses espaços.

Gráfico 6: Número de museus da cidade do Rio de Janeiro que possuem programação específica para o público de Educação Infantil por tipo de atividade oferecida para crianças de 0 a 3 e de 4 a 6 anos

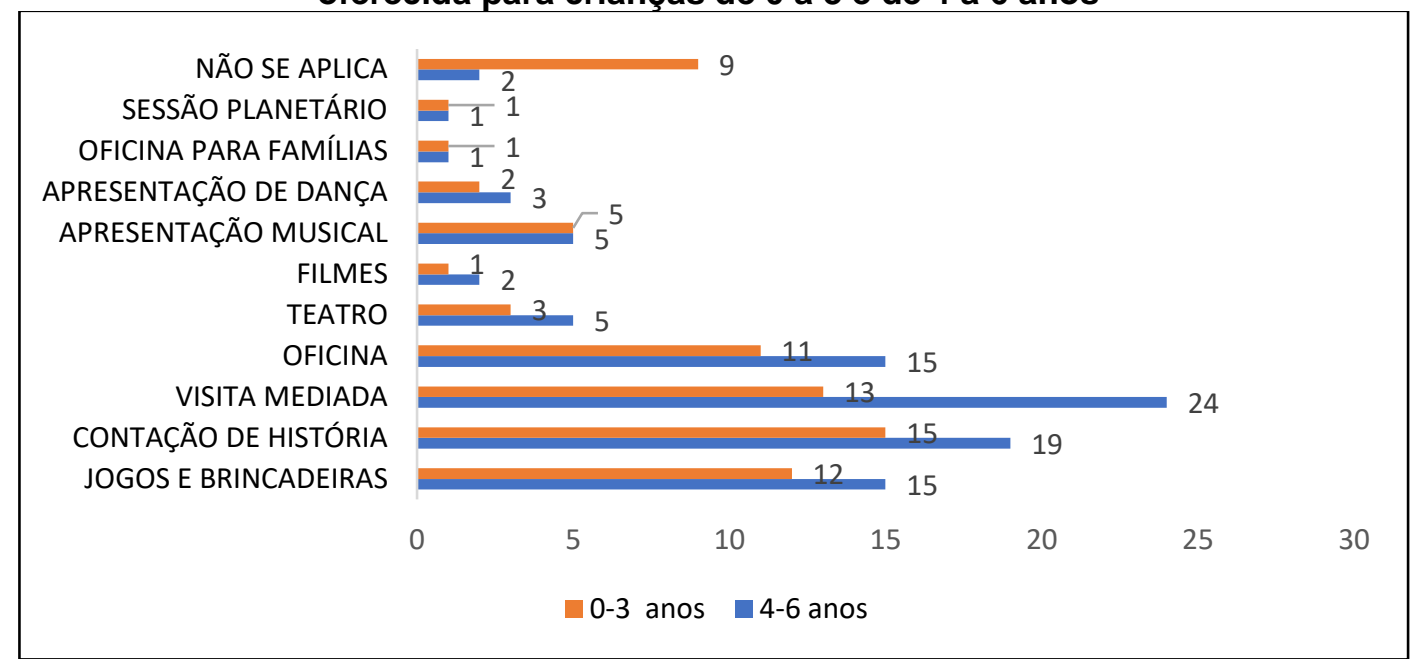

Fonte: CARVALHO et al. (2015)

Ainda observando o gráfico 6 , é possível verificar que as atividades mais recorrentes para as crianças de 0 a 3 anos segue a seguinte ordem: $1^{\circ}$.contação de histórias, $2^{\circ}$.visitas mediadas, $3^{\circ}$.jogos e brincadeiras e $4^{\circ}$.oficinas. Detectar a diversidade nas ações educativas desses espaços para além das visitas mediadas é um fator positivo. Contudo, é preciso compreender as razões para a reduzida quantidade de visitas mediadas para esse público.

Com crianças de 4 a 6 anos, atividades variadas também foram mencionadas para essa faixa etária. Entretanto, aumenta consideravelmente o número de instituições que oferecem visitas mediadas em sua programação. Cabe, portanto, questionar se a quantidade reduzida de visitas mediadas nos espaços expositivos para as crianças menores está relacionada a fatores como a incompreensão de que esse público possui o direito de acesso aos bens culturais e ao desconhecimento por parte das instituições sobre a importância da apropriação cultural no desenvolvimento infantil. Nesse sentido, é importante ressaltar, conforme destaca Carvalho (2013, p. 311), que as crianças pequenas merecem o “(...) reconhecimento de que são capazes de frequentar esses espaços, de que têm esse direito - como sujeitos e cidadãos -, de que têm especificidades que precisam ser respeitadas".

Refletindo sobre a relação que pode ser estabelecida com crianças menores de três anos, Fallon e Chavepeyer (2013) destacam que, de início, a visita ao museu pode ser compreendida enquanto um passeio, sem um retorno muito "útil". Todavia, famílias e educadores podem se surpreender com o prazer que é 
descobrir o mundo junto com as crianças. Ao se deparar inesperadamente com um objeto, brincar com os movimentos de uma escultura, reconhecer um personagem ou uma cena familiar em uma obra - o encontro com os espaços museológicos vai acontecendo.

Nas primeiras semanas e nos primeiros meses de vida, a visita pode ocorrer com o bebê no colo, no prazer do diálogo sensorial, emocional e motor. Desta forma, o bebê vai virando seu olhar para fora, na companhia do outro o mundo ganha significado. De início, os objetos apresentados no museu são, simplesmente, coisas. Essas coisas começam a existir no olhar conjunto do bebê com o outro (família/educador/outros bebês) e na relação de brincadeira e troca que envolve esse olhar. Essa é uma relação de jogo livre, em que nada é esperado em termos de produção ou resultados. Um relacionamento em que a confiança e o prazer estão entrelaçados para dar espaço e significado às percepções, e a visita ao museu se torna uma experiência cultural (SANTOS, 2017). No decorrer dessas conexões, a criança cresce e se apropria da cultura. "Podemos confiar na capacidade da criança de apreciar formas, cores, volumes, ritmos, objetos assim descobertos; no decorrer dessas reuniões, a formação cultural se desdobra, as obras se revelam no mundo íntimo da criança. E o adulto se maravilha ao ver que a criança se maravilha" (FALLON e CHAVEPEYER, 2013, p. 4, tradução da autora).

Compreendendo essa relação profícua que pode ser estabelecida, outro aspecto investigado pela pesquisa do GEPEMCI foi o local onde ocorriam as atividades com as crianças (gráfico 7). Podendo assinalar mais de uma alternativa, foi possível verificar que, das 30 instituições que oferecem programação específica para E.I, 21 desenvolvem suas atividades nos espaços expositivos, embora sete tenham afirmado não receber as crianças nesse espaço. Outros locais como áreas externas, salas extras ou o próprio espaço do setor educativo, auditórios e bibliotecas também foram citados. 
Gráfico 7: Número de museus da cidade do Rio de Janeiro que possuem programação específica para o público de Educação Infantil por tipo de espaço onde são realizadas as atividades

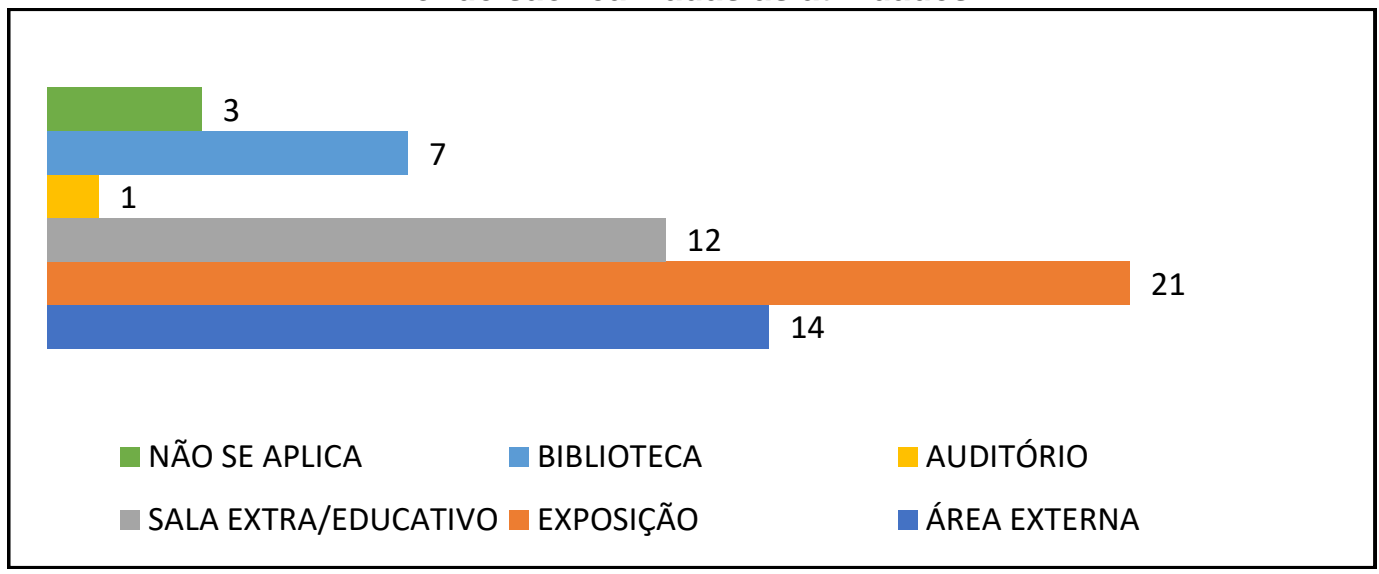

Fonte: CARVALHO et al. (2015)

Examinando a recepção aos grupos escolares em museus e centros culturais, Carvalho (2016) denomina como "pedagogia da visita" uma orientação padrão do trabalho desenvolvido pelos educadores dos museus com esse público. Para turmas de Educação Infantil, principalmente, é comum que as equipes supervalorizem atividades (fora dos espaços expositivos) que envolvam diferentes linguagens do campo artístico (como música, teatro, filme, contação de história), brincadeiras nas salas do educativo, ou uma longa "rodinha" de conversa inicial nos pátios, em prejuízo do desejo de visitar uma exposição. Por vezes, o interesse da equipe do museu pelo uso de distintas linguagens, ou atividades, se torna mais importante do que acolher a intenção da escola de visitar o espaço expositivo com suas turmas. Sobre essa prática nos museus, utilizando o exemplo da contação de história, questiona:

(...) por que ir a um centro cultural ouvir uma história (ainda que buscasse a temática da exposição sem conhecer o espaço, sem visitar as exposições, sem problematizar o lugar, sem estabelecer relações com o próprio espaço, com o acervo, com as imagens? O que terá ficado de visitas como essas? Que significado tiveram? Qual o objetivo? (CARVALHO, 2016, p. 87).

A autora salienta que a probabilidade de as crianças já terem vivido experiências com linguagens do campo artístico em outros espaços sociais (universo escolar, familiar, eventos etc.) é grande em comparação a, talvez, uma das poucas oportunidades de visitar um museu ou centro cultural. Reitera que, nos museus, a aprendizagem se dá por meio do contato com as "coisas reais", que representam a base da experiência museológica e o fundamento de seu potencial educativo. Nessa perspectiva, uma experiência em que a visita à exposição não é realizada - ou seja, quando o contato com o acervo é inviabilizado - se esvazia a potencialidade desses espaços. A experiência estética 
que poderia ser provida, como possibilidade de contato com a obra, não se concretiza em momentos como esses.

Estudos $^{39}$ apontam que essa falta de inclusão efetiva das crianças nos museus e centros culturais decorre do desconhecimento das especificidades desse público pelos profissionais que desenvolvem as ações educativas. Mesmo os espaços museológicos que se abriram para o público infantil, muitas vezes, não compreendem e acolhem as especificidades do trabalho educativo com crianças. Regras como não mexer, não falar, não correr, não comer, não beber, não ultrapassar as faixas de proteção, não brincar, dentre outras, configuram-se como a tônica que permeia as incursões das crianças nos museus.

Mesmo diante de alguns obstáculos a serem enfrentados, os museus possuem um enorme potencial no desenvolvimento de momentos lúdicos de aprendizagem para o público infantil, desde que se reduza a lacuna entre os estudos teóricos sobre as especificidades da infância e as práticas educativas desenvolvidas pelos profissionais dos museus (CARVALHO e LOPES, 2016; Shaffer, 2015). Considerando esse aspecto, a investigação do GEPEMCI também buscou verificar a formação dos profissionais que desempenham as atividades com o público infantil (gráfico 8). Podendo assinalar mais de uma alternativa, os resultados apontaram que, dos 30 museus que possuem programação para E.I, 16 oferecem a formação para atuar junto a esse público no próprio local, 11 possuem profissionais com formação específica na área da Infância e oito afirmaram que seus profissionais não recebem nenhuma formação. Um dos museus informou que seus mediadores são professores que atuam em escolas e quatro consideraram que a pergunta "não se aplica" aos seus espaços.

${ }^{39}$ Carvalho (2011); Leite (2011); Carvalho e Lopes (2016); Shaffer (2015). 
Gráfico 8: Número de museus da cidade do Rio de Janeiro por formação dos profissionais que realizam as atividades com as escolas de Educação Infantil

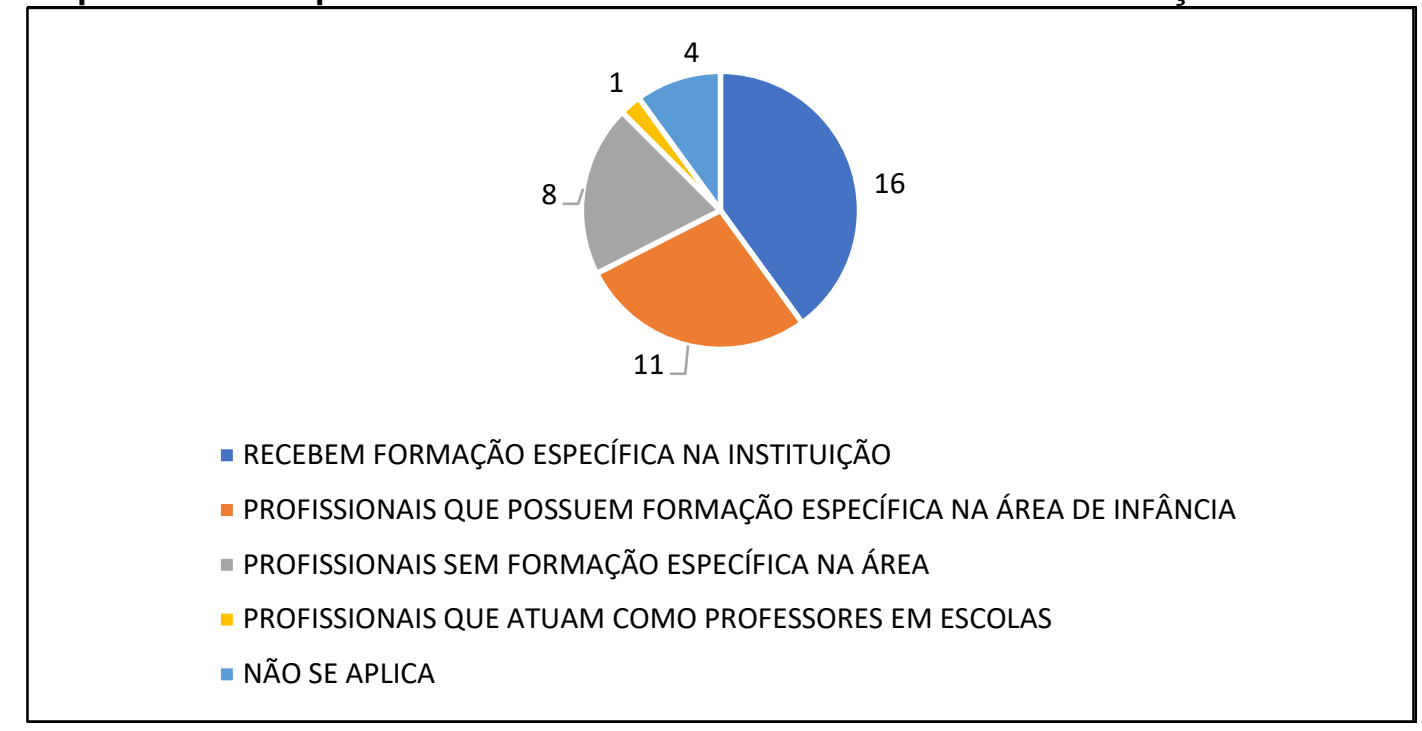

Fonte: CARVALHO et al. (2015)

A lacuna encontrada na formação dos profissionais, aliada à baixa frequência e às poucas instituições que desenvolvem atividades para o público infantil, exige questionar: existe uma preocupação por parte das instituições em oferecer um trabalho com profissionais qualificados?

Tentando responder a essa questão, ao final da pesquisa do Grupo, buscouse saber se os 85 museus (que possuem e que não possuem programação específica para E.I) consideravam que deveriam ocorrer mudanças para melhor receber o público infantil (escolar e espontâneo) e quais seriam essas modificações (gráfico 9). Na análise de dados, 39 instituições sinalizaram a necessidade de mudanças, 10 instituições não consideram necessário e 36 declararam que a opção "não se aplica" aos seus espaços. Dentre as melhorias necessárias, destacaram-se as seguintes ações: criação de programas específicos com tipos de atividades diferenciadas; captação de profissionais habilitados; modificação do espaço expositivo com acervo em altura adequada; espaços para acolhimento; adaptação de conteúdo; adaptação dos banheiros; e o desenvolvimento da imaginação a partir de trabalhos com desenhos e vídeos. 
Gráfico 9: Número de museus da cidade do Rio de Janeiro segundo a necessidade de mudanças para melhorar a recepção ao público infantil

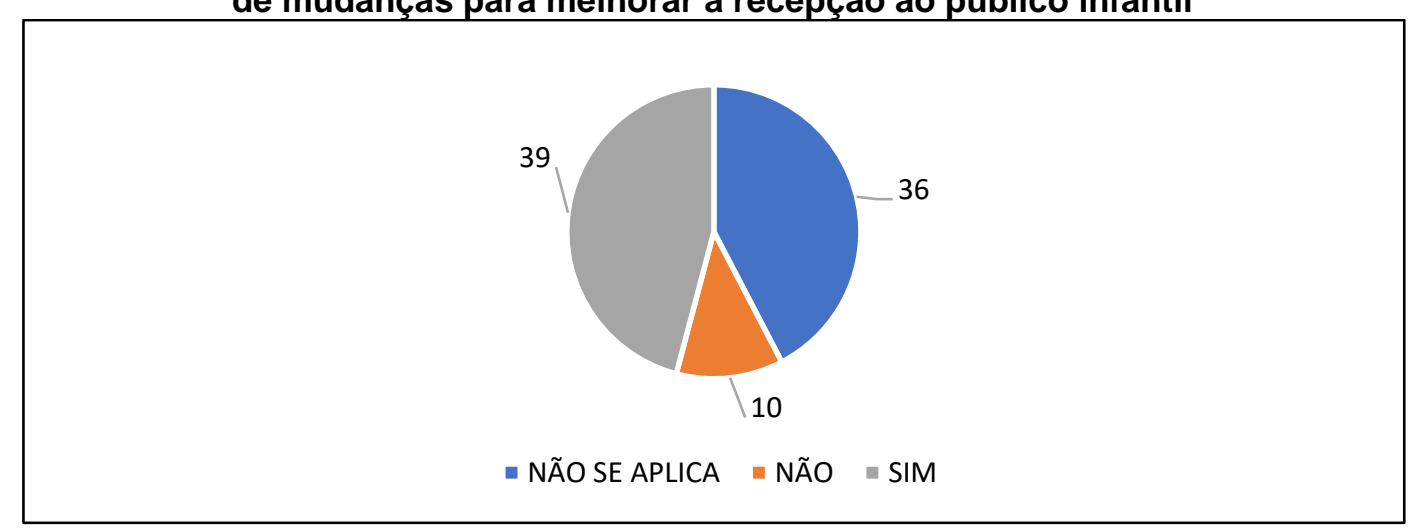

Fonte: CARVALHO et al. (2015)

Os aspectos da recepção ao público infantil que necessitam de melhorias apontados pelos museus e centros culturais da cidade corroboram com os resultados de alguns estudos ${ }^{40}$ que revelam obstáculos frequentemente encontrados nessa relação:(i) a persistência da concepção de que visitas com crianças representam um problema para a segurança das coleções e para a tranquilidade das salas; (ii) a inadequação dos espaços para fazer visitas com propostas diversificadas; (iii) a não adaptação das mensagens expositivas; (iv) a escassez na variedade/reformulação dos programas oferecidos; (v) falta de escuta a esse tipo de público; (vi) o excessivo peso do espaço expositivo e dos espaços de administração frente aos espaços de serviços educativos. Esses aspectos configuram-se, portanto, em barreiras a serem superadas quando se pretende ampliar a relação entre os museus e o público infantil.

Por outro lado, no contexto nacional, é possível identificar alguns avanços nesse campo, como a iniciativa desenvolvida pelo Museu Lasar Segall que, no ano de 2014, realizou o I Seminário Museus e Bebês; reuniões da Rede de Educadores de Museus (REM/ RJ), que em 2015 dedicou alguns encontros ao tema da infância; a mesa redonda "Crianças no Museu: Estudos e relatos de mediação", promovida em 2016 no evento Museu de Ideias; as oficinas de formação de professores desenvolvidas pelo Museu de Arte do Rio sobre crianças e infâncias; o aumento no número de cursos de formação de mediadores que vêm incluindo o debate sobre o público infantil em seus espaços, dentre outras iniciativas.

Essas ações indicam que o debate sobre a presença das crianças nos museus tem alcançado visibilidade. Contudo, as respostas da maioria dos museus e centros culturais da cidade à pesquisa do GEPEMCI, no que tange à recepção

\footnotetext{
40 Ver: Santos (1997); Pol e Asensio (2006); Oliveira (2011); Carvalho e Porto (2013); Leite (2011); Carvalho (2013); Carvalho e Lopes (2016).
} 
ao público de Educação Infantil, demonstram que esta é uma relação que ainda se apresenta de forma frágil. Logo, alicerces que entrelaçam teoria e prática de forma mais contundente são necessários. Em relação aos estudos sobre os problemas encontrados nos museus, Sofka (2009) ressalta que:

Além do ramo de pesquisa referente às suas coleções específicas, o museu moderno, quando preenche suas tarefas primordiais, é também afetado por questões que são investigadas e pesquisadas por várias ciências não abrangidas [diretamente] pelo museu e pela pesquisa disciplinar que nele se desenvolve. Tomemos como exemplo a sociologia, a psicologia, a pedagogia, a estética, as técnicas de informação e comunicação, a engenharia estrutural, a eletrônica, a informática, a engenharia de transportes, a estatística, a economia, o direito e muitas outras áreas. Estas áreas de pesquisa têm seus próprios campos de atividade, mais ou menos relacionados aos museus. É raro que elas iniciem pesquisas por conta própria sobre os problemas dos museus. Vários encontros internacionais com público interdisciplinar têm mostrado claramente que outros ramos da ciência quase nada sabem sobre o papel, o trabalho e os problemas dos museus, ou sobre a ajuda e cooperação que Ihes podem prestar (Sofka, 2009, p. 82).

É possível concordar com as indicações de Sofka (2009), sobre como outras áreas do conhecimento podem cooperar com o trabalho museológico, ao constatar o reduzido número de pesquisas que abordam a relação da Educação Infantil com os espaços museológicos, e ao analisar a literatura que aponta a relação profícua que pode ser estabelecida entre museus e crianças. Aliar os estudos teóricos aos dados obtidos com a pesquisa realizada junto ao GEPEMCI, fomentou diversas questões acerca dessa temática.

Por ter uma trajetória docente vinculada à Educação Infantil, pesquisar esse segmento em visita os espaços museológicos com suas escolas foi um dos motes da investigação desta tese. O estudo realizado por Carvalho (2005), que buscou conhecer as ações e iniciativas dos espaços culturais no que diz respeito ao trabalho junto ao público escolar, já apontava para o distanciamento em relação a todos os segmentos da educação, com ênfase ainda maior para a Educação Infantil. Para a autora, o descompasso existente entre as expectativas da escola e os espaços museológicos, em todos os níveis de ensino, não pode impedir um olhar especificamente para a Educação Infantil. Desta forma, a motivação desta pesquisa foi: Como ocorre atualmente essa relação?

Para Carvalho e Porto (2013), a qualidade das experiências educativas das crianças que visitam museus e centros culturais com suas escolas não se restringe ao espaço, ao acervo, ao trabalho dos mediadores e nem somente à postura dos professores. Consiste, efetivamente, em como todos esses elementos interagem e proporcionam resultados diversos. Levando em conta essa perspectiva, busquei investigar essa relação em sua integralidade, considerando os diferentes agentes nela envolvidos: crianças, professores e museu/mediadores. 
Como os museus e centros culturais que afirmam possuir programação para E.I recebem esse público? Quais ações educativas são, efetivamente, desenvolvidas com as crianças? Qual é a formação dos profissionais que realizam o trabalho com esse público? Quais relações estabelecem com as crianças? E qual é o lugar das crianças nessa relação? Quais são suas expectativas sobre o museu? Como reagem a essa experiência? Quais interpretações e conhecimentos conseguem articular? De que forma os docentes participam dessa experiência? Quais são as motivações para que os professores levem suas turmas aos museus? Quais relações os docentes estabelecem com o conteúdo da exposição, com os mediadores e com as crianças? Os educadores (da escola e do museu) apontam dificuldades nessa relação com os museus?

Buscando responder a essas questões, e tentando aprofundar a compreensão acerca da atual articulação entre museus e o público de Educação Infantil optou-se pela realização de uma pesquisa de campo em alguns dos museus que afirmaram possuir programação específica para esse público (apêndice 1). Conforme explicitado no início deste capítulo (3.1 metodologia da pesquisa), o processo de seleção dos museus e centros culturais a serem investigados culminou com a escolha da Casa da Ciência da UFRJ, Museu Casa de Rui Barbosa e Museu de Arte do Rio.

\section{3. \\ Os museus de arte, ciência e história escolhidos como lócus da pesquisa}

\section{- Casa da Ciência da UFRJ ${ }^{41}$}

A Casa da Ciência da UFRJ (Centro Cultural de Ciência e Tecnologia da Universidade Federal do Rio de Janeiro) foi instituída em 1995 como um centro de popularização da ciência que deveria explorar diversas áreas do conhecimento por meio de linguagens distintas: exposições, oficinas, ciclos de palestras, cursos, workshops, audiovisual e teatro. Inovação, criatividade e imaginação são os valores que norteiam suas ações. Com o objetivo de constituir um espaço democrático e diversificado de relação e mediação cultural para o público, consideram que sua capacidade de reinvenção deve ser permanente. Por esse motivo, a instituição opta por montagens de exposições temporárias de curta duração, pois permitem a constante criação de diferentes cenários e experiências

\footnotetext{
${ }^{41}$ Informações obtidas em documento interno (Plano de Desenvolvimento Interno - PDI) concedido na análise documental da pesquisa, em entrevista com a chefe da Seção de Educação e no site da instituição<wwww.casadaciencia.ufri.br>. Acesso em: 07 mar. 2018.
} 
imersivas de temáticas variadas. A Casa procura estabelecer relações entre ciência, arte e cultura, utilizando distintos experimentos e linguagens, de forma lúdica e participativa, para que seu público seja capaz de refletir, aprender, construir, analisar, repensar e criticar teorias e conceitos desenvolvidos ao longo da história. Desta forma, considera que contribui para o processo de investigação e construção do conhecimento na área de popularização da ciência.

Localizada no campus da UFRJ, da Praia Vermelha, Zona Sul da cidade do Rio de Janeiro, sua arquitetura é composta por uma antiga edificação (construída em 1926 - onde se localizam o pavilhão expositivo e o auditório), um Anexo Administrativo e um pequeno toldo para o desenvolvimento de oficinas.

$\mathrm{Na}$ Casa da Ciência existe um setor específico responsável pelas ações educativas denominado Seção de Educação - nomeado desta forma em janeiro de 2016. A Seção possui uma sala para os profissionais da equipe e um almoxarifado para materiais e outros equipamentos. O público infantil (e os demais) é recebido em todos espaços da Casa onde ocorrem atividades: exposição, auditório e o toldo (parte da área externa onde são realizados oficinas e eventos).

A equipe da Seção de Educação é composta por três técnicos em assuntos educacionais (servidores concursados para o cargo de nível superior da UFRJ) duas pedagogas e um biólogo - e dois auxiliares administrativos (servidores concursados para o cargo de nível médio da UFRJ).

No período de realização do trabalho de campo (maio a dezembro de 2017), a Casa da Ciência recebeu três exposições temporárias: (i) Aedes: que mosquito é esse?; (ii) Imagem e Miragem; (iii) Portinari - Arte e Meio Ambiente. Das três exposições, apenas a primeira e a terceira, foram visitadas por turmas de Educação Infantil.

A exposição "Aedes: que mosquito é esse?" buscou contar, de forma lúdica e divertida, algumas curiosidades da vida do mosquito vetor da dengue, zika, chicungunya e febre amarela. Em uma parceria com o Museu da Vida concepção, organização e montagem -, a mostra era dividida em seis módulos que apresentavam o complexo universo do inseto por meio de aparatos tecnológicos e material multimídia. Vídeos e dispositivos interativos, que abordavam a biologia, a origem, a distribuição e a evolução dos mosquitos Aedes no mundo, eram apresentados ao longo de toda a exposição em totens interativos e televisores expositivos. No módulo Quintal Interativo, era possível observar com microscópios o ciclo de vida do mosquito. O jogo Detetive da Dengue permitiu aos visitantes utilizar um aplicativo no celular para achar 
criadouros do inseto em locais distribuídos ao longo da exposição. No último módulo, o controle do mosquito e a importância da participação da sociedade foram abordados a partir da utilização de óculos de realidade 3D.

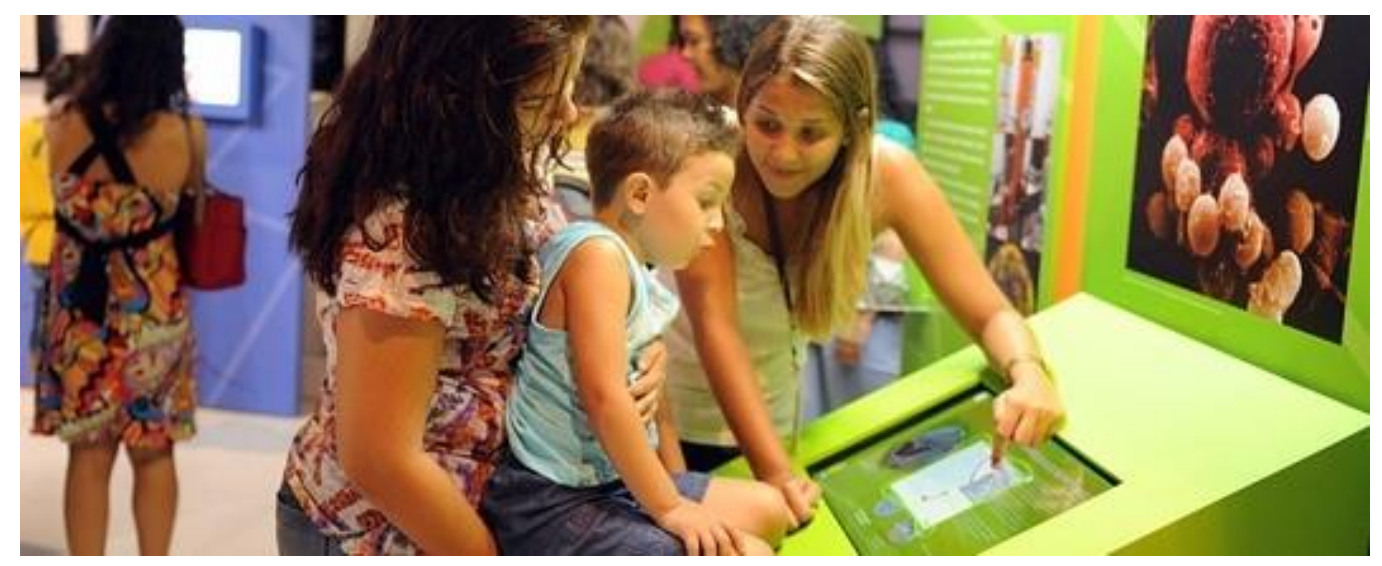

Figura 2: Exposição "Aedes: Que mosquito é esse?" na Casa da Ciência da UFRJ

Fonte: www.portal.fiocruz.br/noticia/aedes-que-mosquito-e-esse

Acesso: 17 dez. 2017

"Portinari - Arte e Meio Ambiente" foi uma exposição que, a partir das obras do artista Candido Portinarii2 ${ }^{42}$, ressaltou a importância do extraordinário legado da fauna, da flora, da cultura e do povo brasileiro, propondo que o visitante repensasse a relação que mantém com as pessoas e com a natureza. Composta por 23 réplicas digitais de pinturas do artista, que aproximavam as temáticas da cultura e do meio ambiente, o principal objetivo da mostra foi apresentar um recorte da imensa obra de Portinari, com trabalhos realizados em diferentes épocas, abordando questões ligadas ao meio ambiente. As obras selecionadas partiram de temas centrais, como a relação dos seres humanos com o espaço, com a água, os recursos minerais, as florestas, a fauna e o equilíbrio entre os seres humanos.

\footnotetext{
${ }^{42}$ Candido Portinari (1903 - 1962) artista plástico brasileiro que participou de uma notável mudança na atitude estética e na cultura do país. Retratou em suas telas o povo brasileiro, superando aos poucos sua formação acadêmica e fundindo a ciência antiga da pintura a uma personalidade experimentalista a antiacadêmica moderna. Informações obtidas em <www.museucasadeportinari.org.br $>$. Acesso em: 15 mai. 2018.
} 


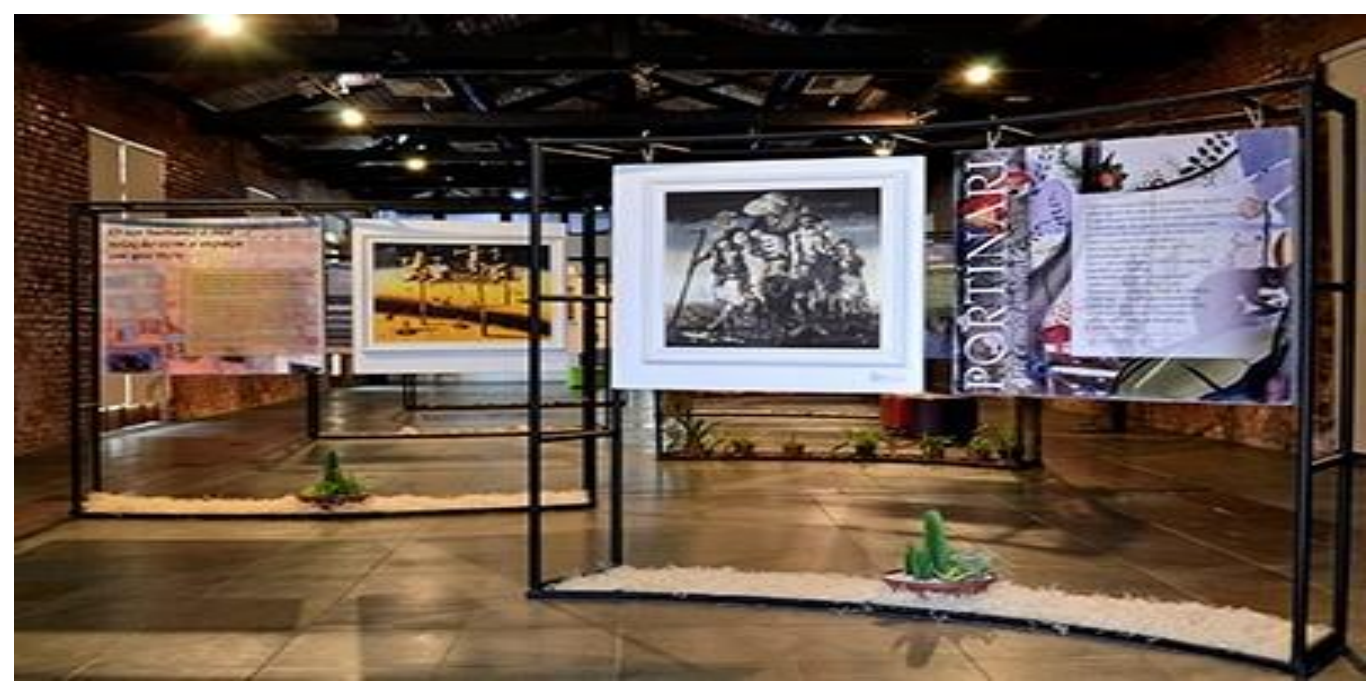

Figura 3: Exposição "Portinari e o Meio Ambiente" na Casa da Ciência da UFRJ

Fonte: Fonte:www.casadaciencia.ufrj.br/portinari

Acesso: 17 dez. 2017

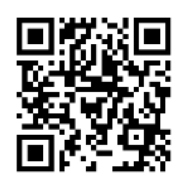

Figura 4: Imagens da Casa da Ciência da UFRJ ${ }^{43}$

\section{- Museu Casa de Rui Barbosa ${ }^{44}$}

A casa, em estilo neoclássico, localizada no bairro de Botafogo (Zona sul da cidade do Rio de Janeiro) foi residência do diplomata Rui Barbosa ${ }^{45}$ e de sua família até 1923. Comprada pelo governo após sua morte, em agosto de 1930 foi inaugurado, no local, o primeiro do gênero Museu-Casa do Brasil, homenageando seu antigo líder político. Núcleo original do que é hoje a Fundação Casa de Rui

43 Imagens da Casa da Ciência da UFRJ e das exposições em cartaz. Para visualizar, através de smartphone ou tablet, basta ter um equipamento com câmera, abrir o aplicativo para leitura de QR Codes (caso não possua baixe um aplicativo gratuito), aproximar o aparelho do QR Code acima e o código com as imagens será aberto automaticamente. Fonte $<$ www.casadaciencia.ufri.br/portinari $>,<$ www.facebook.com/casadaciencia/photos $>,<$ portal.fio cruz.br/noticia/aedes-que-mosquito-e-esse $>$, <portal.fiocruz.br/noticia/exposição-aedes-quemosquito-e-esse>, <ufrj.br/noticia/2017/06/29/aedes-que-mosquito-e-esse>. Acesso em: 17 dez. 2017.

${ }^{44}$ Informações obtidas por meio de documentos internos concedidos na análise documental da pesquisa, em entrevista com a museóloga responsável pelas ações educativas do museu e no site da instituição <www.casaruibarbosa.gov.br> Acesso em: 16 abr. 2018.

${ }^{45}$ Intelectual brasileiro que se destacou como jurista, advogado, político, diplomata, escritor, filólogo, jornalista, tradutor e orador. Foi um dos organizadores da República, membro fundador da Academia Brasileira de Letras e defensor das liberdades civis. Informações obtidas em <www.casaruibarbosa.gov.br>. Acesso em: 16 abr. 2018. 
Barbosa $^{46}$, o Museu desenvolve atividades de pesquisa, conservação e educação, além de promover projetos de integração com a comunidade.

No que tange à educação, o Museu possui como uma de suas metas o trabalho qualificado junto ao público espontâneo e escolar. Analisando os documentos disponibilizados pela Instituição, os projetos desenvolvidos são marcados pelo respeito às diferenças relacionadas às faixas etárias, e buscam oferecer ao público uma experiência cultural que mescle conhecimento, lazer e criatividade.

O acervo que pertenceu a Rui Barbosa compreende, além da biblioteca (com cerca de 37.000 volumes), seu arquivo documental, peças de mobiliário, viaturas antigas, objetos decorativos e de uso pessoal. Os ambientes do Museu permanecem próximos ao original, com as pinturas, os lustres, tapetes e móveis, oferecendo ao visitante uma visão da residência à época em que era ocupada por seu último proprietário. A decoração interior traduz o ecletismo que dominou a arte no Brasil no final do século XIX e início do XX, como reflexo de uma sociedade em transformação.

O jardim que cerca a Casa, musealizado por seu interesse histórico e artístico, é considerado um jardim histórico. A vegetação ainda é bem semelhante à da época de Rui Barbosa, que gostava de cultivar novas espécies no jardim. Atualmente é um espaço frequentado por muitos idosos, crianças e seus cuidadores no período da manhã, e possui um quiosque onde algumas atividades culturais são realizadas. O interior do jardim possui ainda uma exposição permanente que descreve seus detalhes paisagísticos, suas plantas e a história do bairro de Botafogo.

O Museu Casa de Rui Barbosa, por ser um setor da Fundação Casa de Rui Barbosa, não possui, especificamente, um setor educativo. Dentro do Museu não há setores formais ${ }^{47}$. Entretanto, consideram que, historicamente, a educação foi um aspecto valorizado na Instituição, ainda que não possuam um setor formal.

\footnotetext{
${ }^{46}$ A Fundação Casa de Rui Barbosa (FCRB) tem como finalidade o desenvolvimento da cultura, da pesquisa e do ensino, cumprindo-Ihe, especialmente, a divulgação e o culto da obra e da vida de Rui Barbosa (Lei 4.943, art 4º). Desenvolve estudos e pesquisas nas seguintes áreas: estudos ruianos, política cultura, história, direito, filologia e cultura brasileira. Oferece um espaço reservado ao trabalho intelectual, à consulta de livros e documentos e à preservação da memória nacional. Informações obtidas em<www.casaruibarbosa.gov.br>. Acesso em: 16 abr. 2018.

${ }^{47}$ No período de realização da pesquisa foi informado (em entrevista com a coordenadora responsável pelas ações educativas) que estava sendo concluída a construção do Plano Museológico do Museu Casa de Rui Barbosa. O documento incluiria a divisão de três núcleos temáticos: núcleo de comunicação e educação, núcleo de conservação e núcleo de documentação.
} 
Desde a abertura e funcionamento da Casa, na década de 1930, há registros de ações educativas, sobretudo visitação escolar. Em um estudo historiográfico ${ }^{48}$, produzido na Instituição, encontram-se imagens e registros fotográficos de ações educativas realizadas com grupos de escola, normalistas, com a comunidade, com a terceira idade, públicos com deficiência, dentre outros. Atualmente, as atividades educativas do museu possuem cunho lúdico-pedagógico e dividem-se entre as visitas mediadas, oficinas e cursos. Das ações voltadas para o público infantil, destacam-se: o site infantil, a programação mensal "Um domingo na Casa de Rui Barbosa" e "Roteiros de descoberta".

As atividades são realizadas sem o uso de materiais. Em geral, realizam uma contação de história com as publicações do acervo da Biblioteca Infantojuvenil Maria Mazzetti (BIMM) ${ }^{49}$ e visitação ao Museu e ao jardim, com brincadeiras que exploram os aspectos visuais do acervo. Não existe uma sala específica para o desenvolvimento de ações educativas, nem para a equipe responsável. As visitas com grupos de Educação Infantil ocorrem em todo o Museu.

A equipe é composta por três profissionais - duas museológas (concurso público de nível superior) e uma funcionária técnica (concurso público de nível médio) que também possui graduação em museologia - e dois estagiários. Todos são responsáveis por estruturar como serão organizadas as visitas, as ações e as exposições. Apesar da equipe reduzida, os projetos educativos são apresentados em reuniões e recebem contribuições da chefe do Museu (que possui grande experiência na área de educação) e de profissionais de outros setores.

Durante a realização da pesquisa de campo, foi observada a visita de uma turma de Educação Infantil no programa "Roteiros da descoberta". O programa tem como objetivo apresentar alguns aspectos do Museu - casa histórica/exposição permanente, jardim, garagem, biblioteca infantojuvenil. Entretanto, no período acompanhado (2017), a biblioteca infantojuvenil, algumas salas da casa histórica e a garagem encontravam-se fechadas para reforma.

\footnotetext{
${ }^{48}$ Albernaz (2006).

49 A biblioteca Infantojuvenil Maria Mazetti, inaugurada em 02/04/1979 (Dia internacional do Livro Infantil), como é uma homenagem à educadora e escritora Maria Mazzetti. Seu principal objetivo é estimular a literatura como fonte de lazer. Informações obtidas em<www.casaruibarbosa.gov.br/paracriancas $>$. Acesso em: 17 mai. 2018.
} 


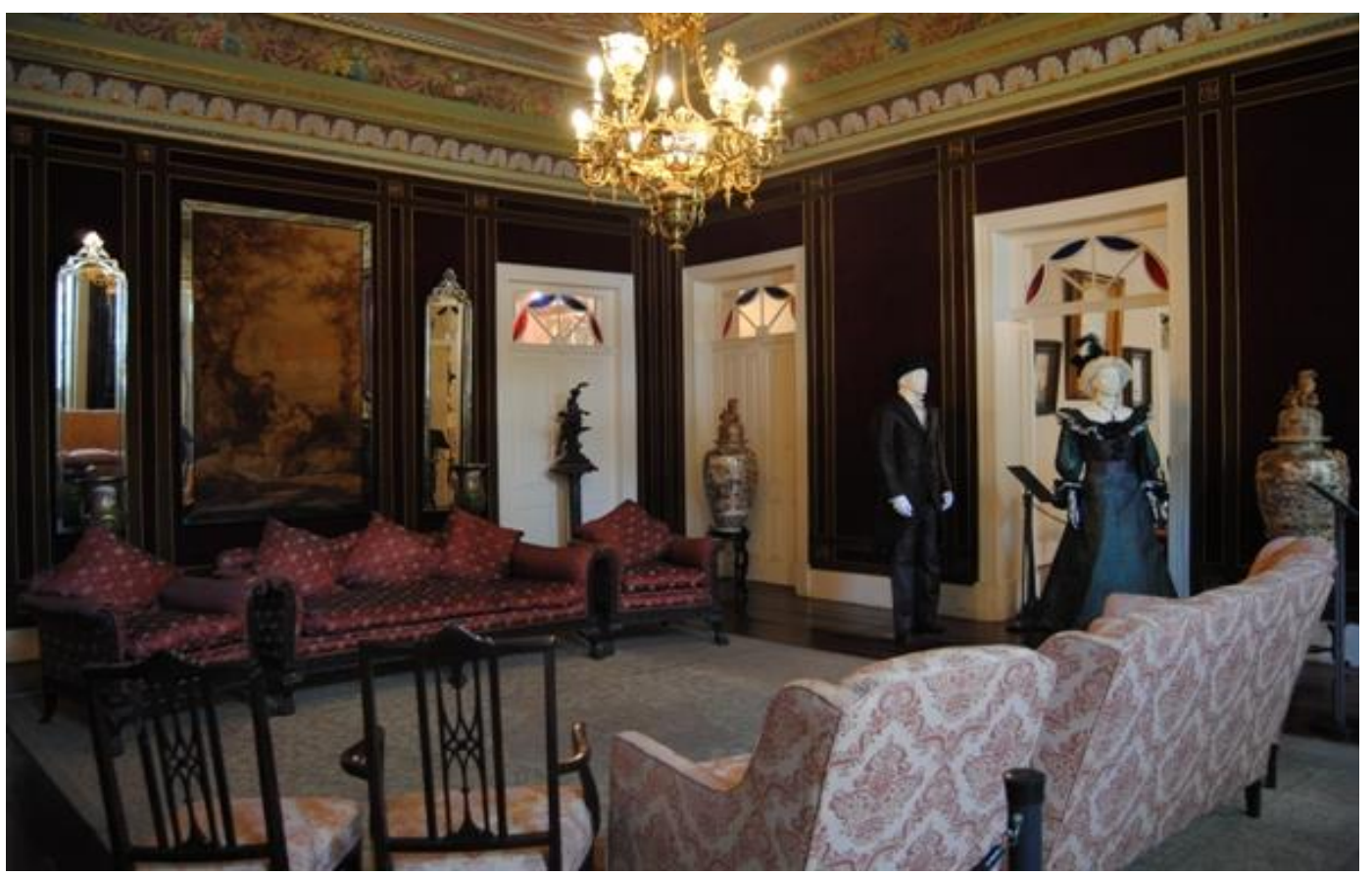

Figura 5: Exposição Museu Casa de Rui Barbosa / Sala de Música

Fonte: www.museusdorio.com.br

Acesso: 19 dez. 2017

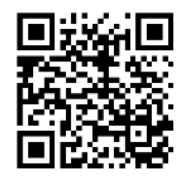

Figura 6: Imagens do Museu Casa de Rui Barbosa ${ }^{50}$

\section{- Museu de Arte do Rio ${ }^{51}$}

O Museu de Arte do Rio (MAR), fundado em março de 2013, está localizado na Praça Mauá (centro da cidade do Rio de Janeiro), sendo parte do projeto de reforma da região portuária do município. Sua arquitetura é composta por dois prédios heterogêneos que são unidos por meio de uma passarela em forma de onda: o Palacete Dom João VI (tombado e eclético) e o edifício vizinho (de estilo modernista). $O$ antigo palacete abriga as salas de exposição. $O$ prédio vizinho é o espaço da Escola do Olhar, departamento destinado à promoção das experiências de formação e educação do Museu.

50 Imagens do Museu Casa de Rui Barbosa. Para visualizar, através de smartphone ou tablet, basta ter um equipamento com câmera, abrir o aplicativo para leitura de QR Codes (caso não possua baixe um aplicativo gratuito), aproximar o aparelho do QR Code acima e o código com as imagens será aberto automaticamente. Fonte:<www.casaruibarbosa.gov.br>, $<$ www.museusdorio.com.br $>,<$ www.cazadoresdebibliotecas.com $>,<$ www.riodejaneiroaqui.com/port ugues/rui-barbosa>. Acesso em: 19 dez. 2017.

51 Informações obtidas em documento interno concedido na análise documental da pesquisa pela Coordenação de Projetos, em entrevista com a Educadora de Projetos e no site da instituição<http://www.museudeartedorio.org.br>. Acesso em: 05 mar. 2018. 
A Instituição tem como missão desenvolver um espaço onde a cidade se encontre e se reinvente através do conhecimento da arte e da experiência do olhar, com ênfase na educação e na formação de acervo. Com tipologia autodeclarada de arte e cultura visual, é um espaço de natureza administrativa público-privada resultante da parceria entre a Prefeitura do Rio de Janeiro e a Fundação Roberto Marinho.

Sua prática museológica reside na coleta, registro, pesquisa, preservação e devolução à comunidade dos bens culturais sob a forma de exposições, catálogos e programas educacionais. Possui coleção própria cujo acervo, adquirido por meio de aquisições e doações, conta com seis mil itens museológicos, 6.025 arquivísticos, 12.180 bibliográficos.

No site da Instituição é possível identificar sua missão: "o Museu de Arte do Rio busca promover uma leitura transversal da história da cidade, seu tecido social, sua vida simbólica, conflitos, contradições, desafios e expectativas sociais. Suas exposições unem dimensões históricas e contemporâneas da arte por meio de mostras de longa e curta duração, de âmbito nacional e internacional."

Portanto, com a missão de inscrever a arte no ensino público, o Museu já nasceu com uma escola - a Escola do Olhar. Como possuem a Escola, o Museu afirma que não existe um setor educativo. Segundo a Educadora de Projetos da Instituição:

Não temos setor porque o MAR é um museu-escola, ele nasceu com a educação como carro-chefe junto com um programa de exposições e acervos. No momento em que a educação é um dos pilares, não temos apenas um setor de educação, temos uma escola que é a "Escola do Olhar". (Entrevista - Clarisse / Educadora de Projetos)

A Escola do Olhar dispõe de um prédio somente para suas ações. A equipe de profissionais (Gerência de Educação) possui um amplo salão dividido em três ambientes: 1 sala para o Gerente, 1 sala comum para os educadores de projeto e mediadores (que funciona como laboratório de criação da equipe que desenvolve seus próprios materiais) e 1 sala para os mediadores (utilizada como sala de descanso e pequenas reuniões). O ambiente possui armários onde são guardados todo o material de mediação produzido pelos próprios educadores e um grande quadro branco onde esquematizam e expõem as ações.

O prédio da Escola do Olhar possui também algumas "salas ateliê" para o desenvolvimento de cursos e workshops destinados ao público. Todas as salas têm pia, mesas e cadeiras móveis. As atividades destinadas ao público infantil ocorrem em todos os espaços públicos do Museu - das exposições às "salas ateliê". 
A Gerência de Educação é responsável pelos projetos educativos e pela educação na Instituição e sua equipe é composta por 10 profissionais: 1 gerente (História); 3 educadores de projetos (Cinema, História, História da Arte); 1 educador/mediador sênior e 10 educadores/mediadores júnior - todos $\mathrm{CLT}^{52}$ (História, Pedagogia, Filosofia, Arte, História da Arte, Escultura); 4 estagiários (Letras, Arte, Pedagogia Libras); 1 apoio administrativo; 1 jovem aprendiz; 1 gerente de projetos (financeiro).

Compreendendo a educação como prática de criação e experimentação, suas ações são elaboradas a partir de seis projetos: 1 - Visitas Educativas, 2 Formação com Professores, 3 - Vizinhos do MAR, 4 - MAR na Academia, 5- Arte e Cultura Visual e 6 - Biblioteca e Centro de Documentação.

Para a realização desta investigação, as ações observadas integravam o projeto "Visitas Educativas". Nesse programa - a partir da relação entre exposições, público e educadores - são intensificadas as experiências sensíveis e reflexivas com a arte, a cultura e a cidade. As visitas educativas são oferecidas para públicos escolares e não escolares, a partir de programações educativas agendadas, oferecidas com horários pré-estabelecidos, com 4 eixos temáticos que são previamente escolhidos pela escola/responsável pelo agendamento:

1- Vejo o Rio de Janeiro: A visita propõe um diálogo sobre os diferentes olhares e percursos sobre o Rio de Janeiro, presentes nas exposições do MAR. Tem como interesse discutir como as representações da cidade e seus aspectos socioculturais contribuem para a constituição de um imaginário carioca por meio das artes, da arquitetura e da prática urbana.

2- Guardar para lembrar: Visita destinada a pensar sobre as relações entre memória e coleção e sobre os museus como espaços de construção de identidades coletivas a partir da constituição de um patrimônio.

3- Práticas artísticas contemporâneas: Nesta visita são investigados os processos de pesquisa e construção artísticas presentes em exposições de arte contemporânea, bem como as diferentes linguagens utilizadas pelos artistas na construção de uma obra de arte.

4- Meu corpo no museu: A visita se propõe a refletir sobre as questões do corpo na arte, na sociedade e no museu. Discute as formas de representação e construção dos corpos e sobre as relações individuais e coletivas com o espaço.

Conforme mencionado, a observação realizada nesta pesquisa consistiu no acompanhamento das atividades desenvolvidas pelos mediadores com as turmas de Educação Infantil no projeto "Visitas Educativas", no ano de 2017, nos quatro eixos temáticos supracitados. Na época de realização da pesquisa de campo, o Museu estava exibindo concomitantemente três exposições: Dja Guata Porã: Rio

\footnotetext{
52 No Museu de Arte do Rio os profissionais que realizam a mediação com os diferentes públicos, em sua maioria, são profissionais formados que possuem vínculo empregatício com a instituição. A equipe é dividida entre os cargos "sênior" e "júnior" conforme tempo de atuação e função exercida na instituição.
} 
de Janeiro indígena; Feito Poeira ao Vento: Fotografias da Coleção MAR; Dentro: Programa da Sala de Encontro.

A exposição Dja Guata Porã: Rio de Janeiro Indígena apresentou a história do Estado do Rio de Janeiro como uma história indígena. Concebida com a colaboração de povos, aldeias e indígenas que residiam no estado ou na capital carioca, a exposição foi fruto de uma plataforma de colaboração entre práticas museológicas e indígenas. Obras, vídeos, fotografias e outros dispositivos, entrecruzados com documentação e iconografia, apresentavam uma linha do tempo que contextualizava conceitos, períodos e acontecimentos. Em cinco estações foram apresentados temas que atravessavam épocas e povos, denotando sua relevância para a história cultural e de resistência dos povos indígenas: educação, comércio, arte, natureza e mulher. Contou, também, com uma instalação sonora que projetava o som de diferentes línguas indígenas na passarela que recebia os visitantes dando acesso ao pavilhão expositivo. A mostra buscou convocar e potencializar a dimensão polifônica da diversidade cultural dos povos que fazem a história do Rio de Janeiro e do Brasil.

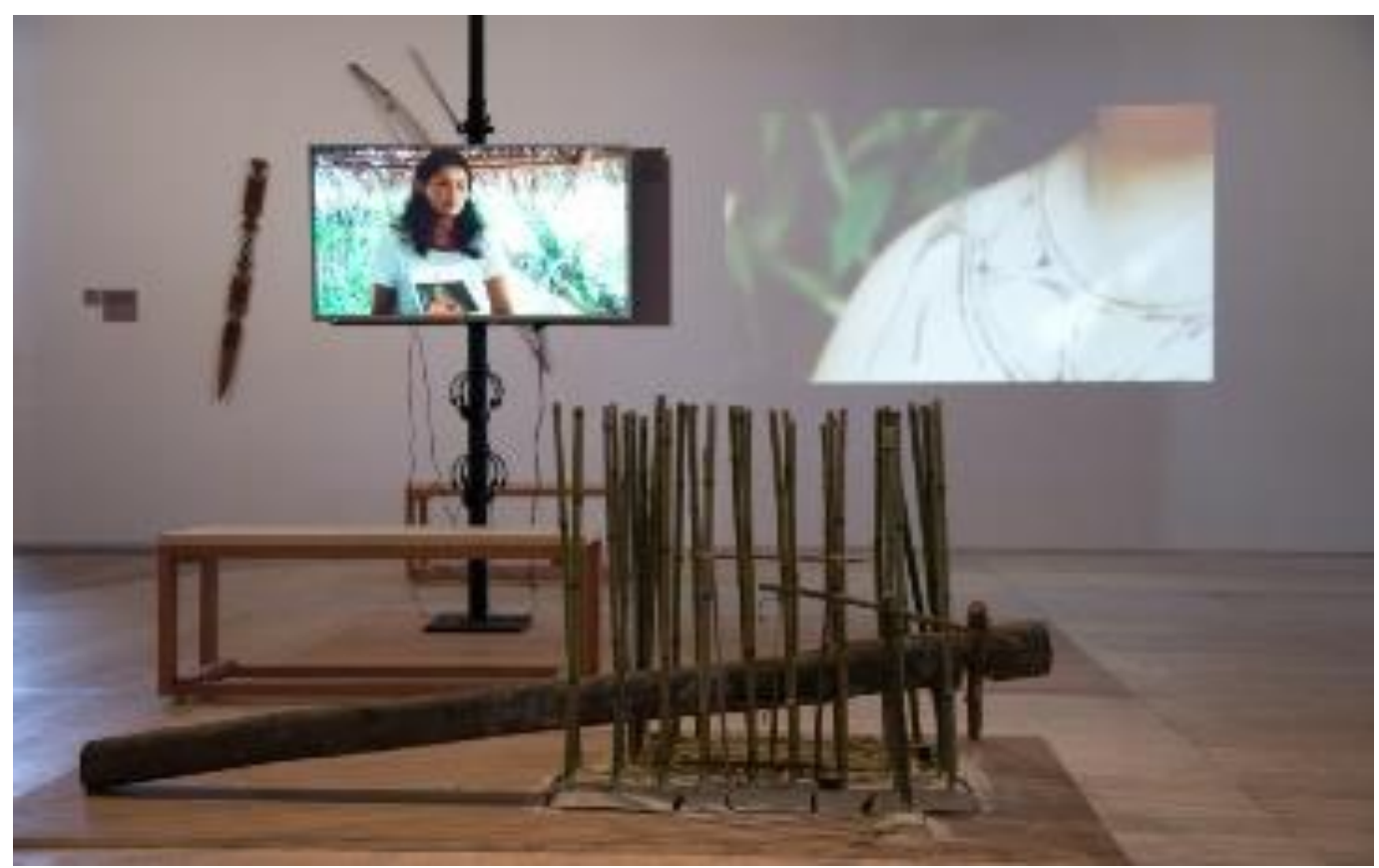

Figura 7: Exposição “Dja Guata Porã” no Museu de Arte do Rio

Fonte: www.museudeartedorio.org.br/pt-br/exposicoes/atuais $? \exp =4653$

Acesso: 18 dez. 2017

Feito Poeira ao Vento foi uma exposição fotográfica de artistas que têm reinventado não somente a dimensão estética da imagem fotográfica, como também seu próprio estatuto documental, inserindo a fotografia no campo da ficção e da reinvenção do mundo. Buscava mostrar a interdisciplinaridade da 
fotografia e como sua potência de criação dá suporte a plataformas diversas como o livro, o vídeo, a instalação, a pintura ou a performance. Era composta por uma coleção de fotografias brasileiras (pontuada pela presença de alguns artistas internacionais) de natureza diversa, produzidas desde fins do século XIX aos dias atuais.

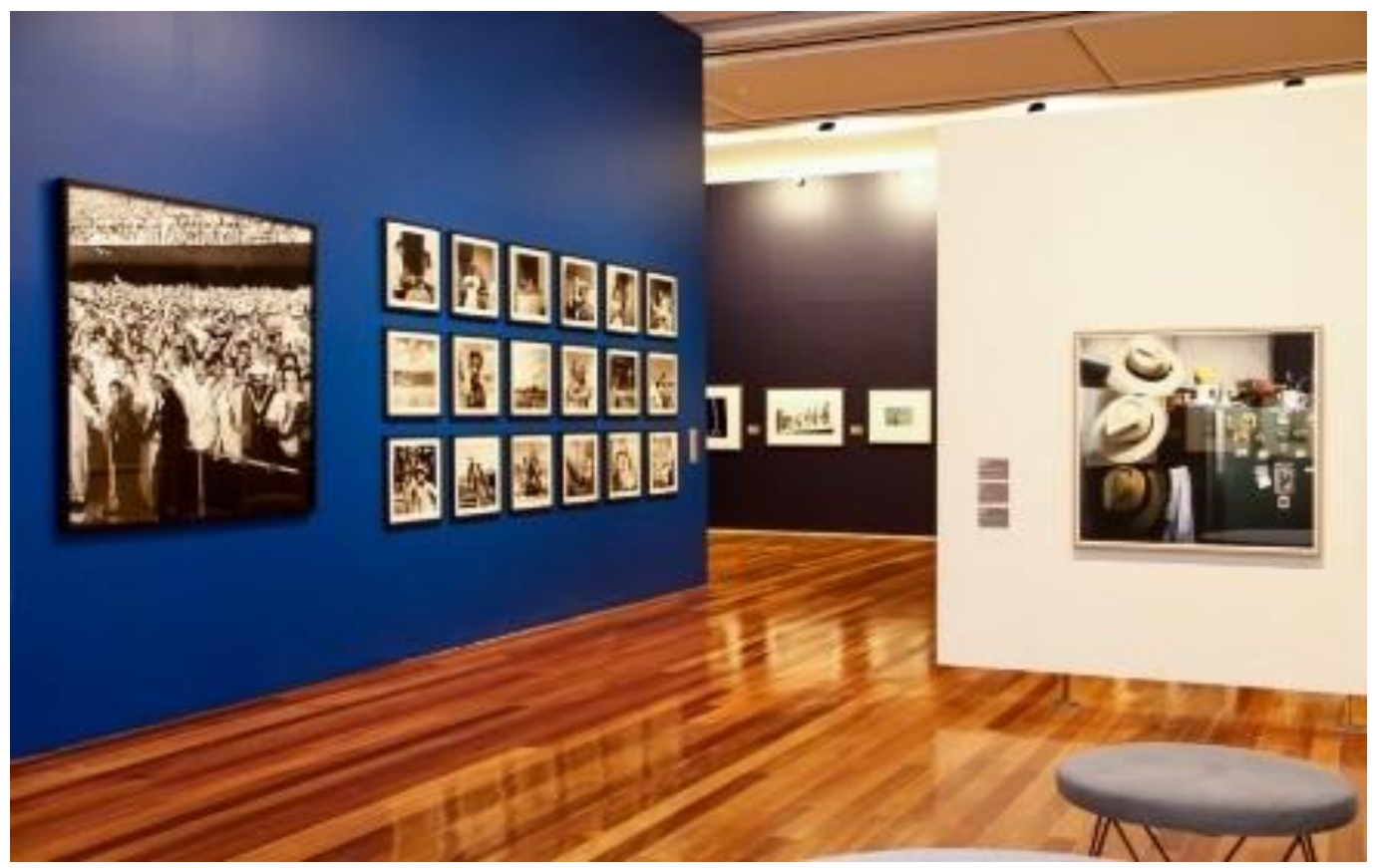

Figura 8: Exposição "Feito Poeira ao Vento" no Museu de Arte do Rio Fonte: www.museudeartedorio.org.br/pt-br/exposicoes/atuais?exp $=4824$ Acesso: 18 dez. 2017

A exposição Dentro foi a primeira mostra do programa Sala de Encontro, um espaço imersivo dedicado a exposições especiais que propõem um encontro direto e intenso com o universo poético, plural e híbrido da arte. Destinada a todos - e em especial a crianças e jovens - buscava explorar e incitar a criação de meios de experimentação e reflexão em torno da arte. A exposição (e o espaço da Sala e Encontro em si) teve como proposta promover um campo experimental de troca e aprendizado entre dois mundos: o da arte e o de quem a experimenta, o da linguagem aberta da arte e $o$ da linguagem que se configura como instrumento e lugar do sujeito no mundo, o de um museu socialmente ativo e o de seu público. 


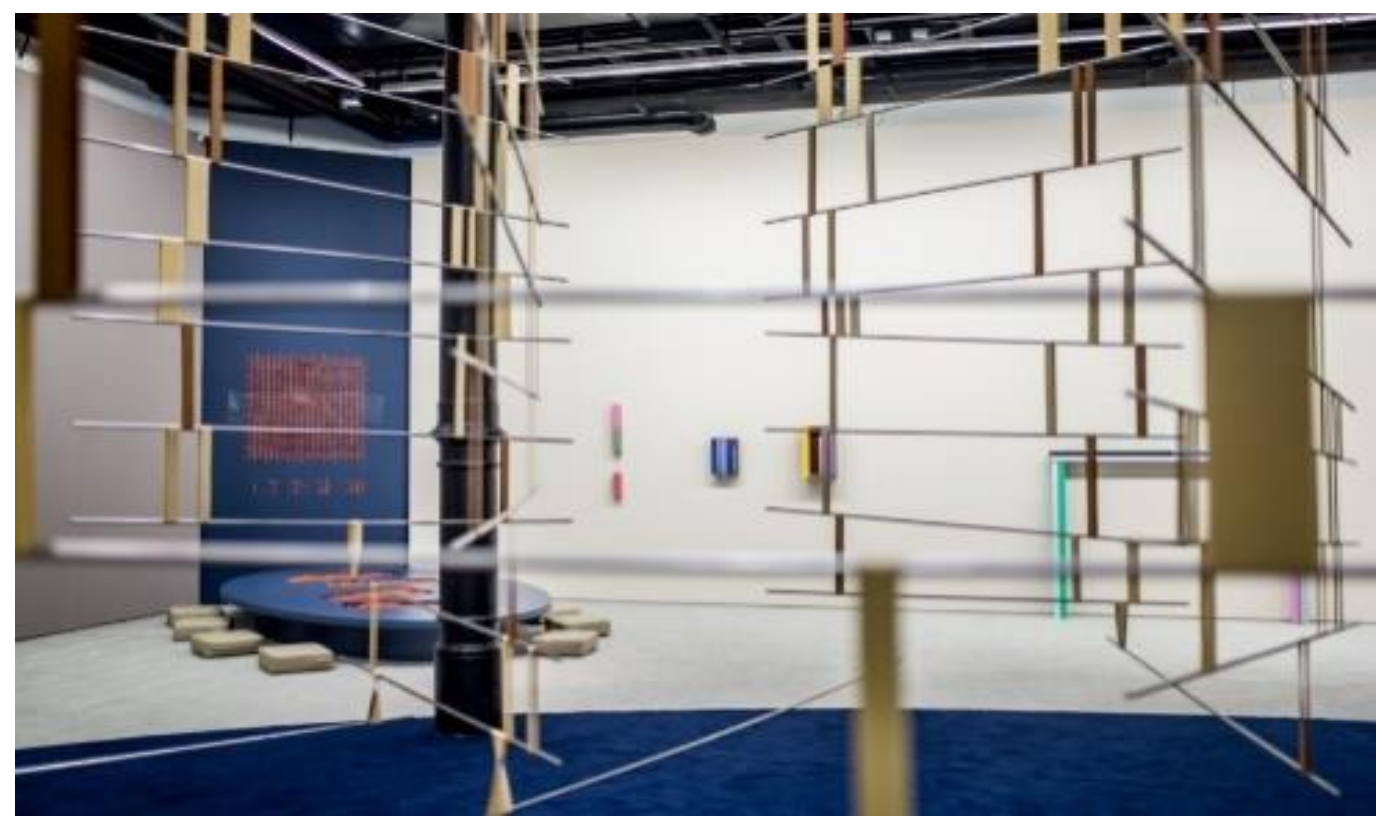

Figura 9: Exposição "Dentro" no Museu de Arte do Rio

Fonte: www.museudeartedorio.org.br/pt-br/exposicoes/atuais?exp $=4824$

Acesso: 18 dez. 2017

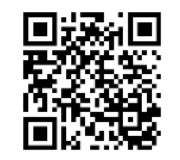

Figura 10: Imagens do Museu de Arte do Rio 53

\section{4. \\ Espaço expositivo - possibilidade de mobilidade, autonomia, brincadeira e expressão?}

Refletindo sobre as possibilidades a serem exploradas pelas crianças nos diferentes espaços museológicos, Fallon e Chavepeyer (2013) destacam que os museus, geralmente, são monumentos arquitetônicos, obras de arte em si. Para além dos conteúdos expositivos, apontam diversos elementos que podem ser atrativos para as crianças, como as grandes escadas, os tetos altos, as perspectivas, a arquitetura imponente, ou até mesmo o murmúrio das vozes ou o silêncio. Como as crianças estão sempre atentas aos detalhes que estão ao seu alcance ou à altura de sua mirada (que nem sempre são os objetos do acervo), também se interessam pelas entradas de ar, pelos extintores, pelos sinais indicativos, dentre inúmeras possibilidades.

53 Imagens do Museu de Arte do Rio e das exposições em cartaz. Para visualizar, através de smartphone ou tablet, basta ter um equipamento com câmera, abrir o aplicativo para leitura de QR Codes (caso não possua baixe um aplicativo gratuito), aproximar o aparelho do QR Code acima e o código com as imagens será aberto automaticamente. Fonte: <www.museudeartedorio.org.br/ptbr/exposicoes/atuais?exp=4595>. Acesso em: $18 \mathrm{dez}$. 2017. 
Quanto aos espaços expositivos e à disposição do acervo - uma infinidade de imagens, formas, personagens - raramente são encontradas niveladas à altura das crianças. Ressaltam que esse fato não deve ser visto como um impedimento na recepção ao público infantil e na garantia do direito de frequentarem as exposições, pois, com algumas adaptações práticas para que crianças, famílias e escolas se sintam seguras, o museu pode se tornar um local habitável para os pequenos. Afinal, as crianças, cotidianamente imersas na vida dos adultos, não possuem todas as coisas do mundo adaptadas ao seu tamanho. As autoras garantem que, adotando algumas adaptações práticas na forma de olhar para esse público, as crianças só precisam de tempo para se apropriarem dos lugares e apreciá-los.

Sentar-se, deitar nos braços da mãe para olhar para os tetos altos, subir as escadas engatinhando, descobrir os detalhes de um trabalho subindo nos ombros do pai, assim como ler uma história ou cantar, são jogos que permitem que eles [crianças] descubram obras sob diferentes pontos de vista. Tornam a visita dinâmica e ajudam adultos e crianças a brincar juntos (FALLON e CHAVEPEYER, 2013, p. 12, tradução da autora).

Analisando a qualidade estética que pode permear os espaços expositivos em museus e centros culturais, Wagensberg (2008) aponta dois aspectos importantes no que se refere à relação com o público infantil: a não utilização de textos e a atenção às escolhas estéticas nas exposições. Ao receber crianças, que ainda não sabem ler, o autor indica a realização de atividades que sejam multissensoriais, que não privilegiem somente a visão, mas também o tato, a audição, o olfato e até mesmo o paladar. Em seu entendimento, o museu serve para provocar estímulos para que seus visitantes possam aprender, formar-se e informar-se. O público infantil, portanto, pode ser estimulado por meio de propostas multissensoriais que provoquem a troca das crianças com outras crianças, com os mediadores e com seus acompanhantes.

Em relação às escolhas estéticas das exposições, Wagensberg (2008) examina que não é uma boa alternativa a tendência nos museus em separar o que é feito para crianças do que é feito para adultos. Nesse sentido, vale recorrer aos apontamentos de Benjamin (2012, p.89) no que se refere à constatação de que "a criança exige dos adultos representações claras e inteligíveis, mas não infantis, e muito menos as que os adultos concebem como tais. A criança compreende perfeitamente coisas sérias, mesmo as mais abstratas e pesadas, desde que partam honesta e espontaneamente do coração".

Wagensberg (2008) coaduna com essa perspectiva e sugere que os espaços das crianças e dos adultos deveriam ser mais próximos em todos os 
aspectos, inclusive na estética, possibilitando a interação intergeracional em um mesmo espaço.

Descobri que a suposta estética infantil não agrada necessariamente às crianças. Por exemplo, as crianças de seis a dez anos já querem compartilhar a estética dos mais velhos e se veem uma estética infantil especialmente voltada para elas, sentem-se, não enganadas, mas como se estivessem vendo algo falso, o que não é verdade. A pergunta mais frequente de um menino a partir dos sete anos de idade é: "Papai, isso é verdade ou mentira?" (...). Por outro lado, para crianças menores de seis anos, é possível buscar estéticas adequadas sem precisar apelar para as mais tradicionais, como os animais humanizados. Isso que foi muito usado por Walt Disney não é o único modelo; é possível encontrar outras estéticas interessantes (WAGENSBERG, 2008, p. 69-70).

Oportunizar experiências para a criança no âmbito museal refere-se à possibilidade não apenas de ver o acervo, mas de mergulhar em uma relação lúdica e sensível em que, acionando seu repertório de conhecimento prévio (constituído por sua memória e imaginação) possa ser capaz de criar novos sentidos e conexões. Entretanto, oportunizar essas experiências para as crianças, implica pensar uma apropriação do espaço expositivo que foge ao usual. Normalmente caracterizados por salas e galerias, cujo centro fica vazio ou preenchido por bancos, Leite (2005) questiona sobre esses "miolos" dos espaços expositivos:

Não poderíamos pensar esse "miolo", no meio das galerias, como espaço significativo de criação e significação? Não poderíamos oferecer um sortimento de espaços alternativos - cavaletes, almofadas, mesas, cadeiras, chão - , materiais diferentes - papéis, grafite, carvão, pastel, hidrocor, lápis de cera, sucatas, argila, massa de modelagem, entre outros - , encaminhamentos diversos - desenho, pintura, colagem, escultura -, de forma que a vontade de realizar/produzir pudesse ser mais respeitada, ampliada, incrementada, pudesse ter mais sentido? (LEITE, 2005, p. 51)

Para Pol e Asensio (2006), a inadequação dos espaços para fazer uma visita que tenha a possibilidade de abranger diferentes propostas é também um flagelo que dificulta ou altera, de fato, as abordagens educativas com as crianças nos museus.

O peso excessivo, ainda hoje, do espaço expositivo e dos espaços de administração ou de coleções diante dos espaços de atendimento, continua sendo um dos mais sérios problemas na hora de fazer uma oferta moderna. Em todos os departamentos de educação estamos acostumados com lonas nos pátios e jardins para uso como espaço de acolhimento ou qualquer buraco nas escadas. A surpresa positiva é quando as lonas estão cheias (Pol e Asensio, 2006, p. 12, tradução da autora).

Nesse sentido, oferecer outras configurações e estruturas diferenciadas nos espaços expositivos, contribuiria para que se tornassem mais dinâmicos e atrativos, não apenas para as crianças, mas também para os demais públicos. Essa postura requer uma mudança na mentalidade sobre a visitação nos museus, sobre o papel da visita mediada, dos mediadores etc. 
Alguns estudos ${ }^{54}$ já vêm reiterando e discutindo a urgência dessa mudança na mentalidade sobre a visitação do público infantil nos espaços expositivos, sobretudo no que se refere à persistência de que as crianças são vistas como problema para a segurança da conservação das coleções, tanto pela imagem quanto pela tranquilidade das salas.

As crianças pequenas falam alto, riem, choram, gritam, recusam-se imediatamente, ficam excitadas, correm...em museus e em qualquer lugar. É uma audiência essencialmente dominada por impulsos e ainda pouco apegada às normas sociais (...). Que sinais o museu pode dar para tornar essas regras mais flexíveis e permitir uma visita segura? (FALLON e CHAVEPEYER, 2013, p.12, tradução da autora).

Pol e Asensio (2006) consideram que as novas gerações de conservadores, museólogos e curadores podem representar um caminho para a mudança nessa mentalidade. É necessária a adoção de novas posturas, pois, quanto mais a instituição do museu (e seus profissionais) é perturbada por tais comportamentos e quanto mais se esforça para evitar a expressão das emoções de crianças pequenas, maior o risco de desconforto entre os diferentes sujeitos envolvidos no momento da visita. Por outro lado, quando a equipe reconhece e permite que a vitalidade das crianças seja vivida, proporcionando um ambiente sereno e seguro, há um senso de harmonização entre crianças, pais, mediadores, professores, artistas e públicos. O prazer da descoberta pode circular e o comportamento "desconcertante" das crianças não estará mais em primeiro plano. Para Fallon e Chavepeyer (2013, p. 13, tradução da autora), "a confiança na criança pode ser construída em uma atitude indulgente, acolhedora e aberta a sua pessoa, bem como em um projeto de acolhimento onde espaço compartilhado de prazer, brincadeira, movimento e fantasia podem coexistir e emergir".

Analisando os espaços expositivos das três instituições selecionadas para a pesquisa, foi possível constatar os diferentes elementos apontados na reflexão dos autores. Respeitando a especificidade da temática e expografia de cada exposição, alguns elementos comuns podem ser destacados nas três instituições: a realização do trabalho com as crianças nos espaços expositivos junto à presença dos demais públicos, a não utilização de textos como foco das mediações, a busca por adaptações práticas e a tentativa dos mediadores de mostrar que um grupo de crianças no museu não significa um risco à segurança das coleções.

Conforme já sinalizado a Casa da Ciência da UFRJ contou com duas exposições com temáticas e expografia completamente distintas. Desta forma, as

\footnotetext{
${ }^{54}$ Pol e Asensio (2006), Fallon e Chavepeyer (2013), Shaffer (2015), Leite (2005), Carvalho (2013); Carvalho e Lopes (2016), dentre outros.
} 
características do espaço expositivo também foram diferenciadas. A chefe da Seção de Educação esclareceu em entrevista que nenhuma das exposições que a Casa abriga costuma pensar, especialmente, a inclusão do público infantil. Muitas vezes ocorre um trabalho de adaptação, seja da linguagem para a apresentação do conteúdo pelo mediador ou com tablados para as crianças subirem.

Nas duas exposições observadas, o espaço de realização do trabalho junto ao público infantil (visita e oficina de desenho) foi o salão expositivo. Foi também possível constatar que o acervo das duas mostras estava exposto em uma altura que dificultava o acesso do público infantil. A solução para o acesso das crianças ao acervo contava com adaptações de banquetas para subir ou, até mesmo, que os mediadores pegassem as crianças no colo.

\begin{abstract}
Exposição "Aedes: que mosquito é esse": A maioria do acervo estava disposta em lugares muito altos para observação/manuseio das crianças. Ocorreu um trabalho de adaptação, onde foram disponibilizados pequenos caixotes para que as crianças subissem e tivessem acesso aos totens digitais. No espaço dos microscópios, as bancadas e cadeiras eram altas e os mediadores precisavam pegar as crianças no colo para que também pudessem observar (Caderno de Campo - Casa da Ciência).

Exposição "Portinari e o Meio Ambiente": Os quadros estavam expostos (pendurados em suportes de metal) em uma altura um pouco elevada para o campo de visão das crianças. A estratégia de mediação utilizada, de pedir que o grupo se sentasse a cada obra abordada, por vezes, prejudicou ainda mais a visualização de alguns quadros (Caderno de Campo - Casa da Ciência).
\end{abstract}

Quanto à possibilidade de mobilidade, autonomia, experimentação e brincadeira para as crianças nos espaços expositivos, a exposição "Aedes: que mosquito é esse?" foi concebida de forma a permitir circulação, autonomia e interação com instrumentos científicos e tecnológicos em todos os módulos. "As crianças da Educação Infantil tiveram a oportunidade de percorrer a exposição de forma autônoma, mas demonstraram receio na exploração do espaço." (Caderno de Campo - Casa da Ciência).

Já na exposição "Portinari e o Meio Ambiente", a mobilidade em meio ao espaço expositivo ficou um pouco prejudicada, os grupos escolares precisavam se locomover com cuidado e atenção entre as obras. Em algumas visitas, o espaço apertado chegou a provocar desentendimento entre as crianças que disputavam para sentar mais próximo às obras.

Criança: Aí! Ela me pisou.

Professora: Pede desculpas. Ela não fez de propósito.

Criança: Aí! Tá apertado.

Professora: Pessoal, olha só, acabamos de falar da paz [referindo-se ao quadro anteriormente observado "Guerra e Paz"] e vai começar a briga? Maitê, senta aqui, por favor. Vocês brigam muito! Acabamos de falar da paz e vocês começam a brigar? Nina, senta, por favor! (Caderno de Campo - Casa da Ciência). 
Apesar da Casa da Ciência possuir um amplo pátio que permitiria atividades lúdicas, esse não foi um recurso utilizado. A mediação ocorreu apenas no salão expositivo. A exposição "Portinari e o Meio Ambiente" dispunha as obras em suportes de metal que no chão apresentavam elementos naturais (areia, carvão, flores, folhas, palha) relacionados à temática dos quadros apresentados.

Os elementos naturais dos suportes, que despertavam grande interesse e desejo de manipulação nas crianças, não estavam disponíveis para experimentação no momento da visita, e nem posteriormente, na realização da oficina de desenho (que utilizou apenas papel, lápis e canetinhas). Nesse momento, há um distanciamento do que a literatura aponta sobre as possibilidades multissensoriais a serem exploradas com as crianças nos museus. A temática do meio ambiente e de seus elementos naturais, presente nas obras e na expografia, que poderia ser utilizada de diferentes maneiras, foi transformada em momentos de coerção pelas professoras que a todo momento precisavam conter as crianças para que não fossem ao encontro dos elementos naturais. Esta situação foi recorrente em todas as visitas observadas.

No que se refere aos aparatos e dispositivos utilizados, a exposição "Portinari e o Meio ambiente" continha, em suas laterais, alguns pufes e televisores com vídeos explicativos sobre Portinari. Contudo, esses vídeos não foram explorados em nenhum momento das visitas observadas. A exposição "Aedes: que mosquito é esse" contou com muitos recursos e dispositivos científicos e tecnológicos. Dividida em seis módulos, a exposição utilizou tecnologias de última geração e os seguintes materiais multimídia: (i) Quintal Interativo: era observado com lupas e microscópios, o ciclo de vida do Aedes aegypti e as fases ovo, larva, pupa e alada (adulto); (ii) Jogo Caça ao Foco: apresentava cenários com possíveis criadouros onde o participante deveria identificá-los e tocá-los (no talbet/celular) para eliminar a ameaça; (iii) Fóssil de mosquito em âmbar com cerca de 30 milhões de anos; (iv) Escultura de mosquito fêmea (com mais de dois metros) que recepcionava o visitante com sensores de proximidade distribuídos em partes específicas do modelo e quando acionados por uma lupa projetavam informações em uma tela gigante, com textos, imagens e animações; (v) Totens com vídeos e dispositivos interativos, ao longo de toda a exposição, que abordavam a biologia, a origem, a distribuição e a evolução dos vetores Aedes no mundo; (vi) óculos de realidade virtual etc.

No Museu Casa de Rui Barbosa os espaços de realização do trabalho junto ao público de E.I para a visita foram o Quiosque do Jardim (uma contação de 
história foi realizada nesse espaço porque a BIMM estava fechada para reforma); o Museu Casa e o Jardim Histórico.

A exposição do Museu é permanente e não foi concebida pensando, especificamente, o público infantil e nem o público que necessita de recursos de acessibilidade. A museóloga, responsável pelas ações educativas na Instituição, afirmou que ocorre uma adaptação das ações que buscam explorar aspectos de antiguidade da Casa e do Jardim de maneira lúdica, fazendo observações e comparações com o que as crianças conhecem hoje. Revelou, ainda, o desejo de construírem algumas narrativas específicas para as crianças em meio à exposição.

Ocorre uma adaptação porque nós somos um Museu-Casa. Um Museu-Casa é um espaço que tem uma logística de exposição que não é muito frequente. Basicamente, a exposição muda pouco ao longo do tempo e não tem, nem foi pensada a exposição para o público infantil. Aliás, são poucos os museus que pensam nisso! (...) Temos pensado em criar umas questões para o público infantil no estilo "você sabia?" com personagens que poderiam ser um dos netos do Rui Barbosa, mas não tivemos ainda recursos, nem pessoal para conseguir dar conta dessas demandas (Entrevista - Francisca / Museóloga do Museu Casa de Rui Barbosa).

O acervo composto por móveis de uma casa antiga estava em altura adequada. Por vezes, as crianças queriam tocar e utilizar os móveis e os seguranças se aproximavam. As mediadoras agiam de forma rápida para conter os ânimos da segurança mostrando que a presença das crianças ali não seria um risco ao acervo. Também aproveitavam esses momentos para explicar, em tom de conversa, o motivo pelo qual a mobília não podia ser utilizada como em uma casa normal, fazendo, assim, com que as crianças entendessem a especificidade de um Museu-Casa.

Mediadora: Quando chego na minha casa deito na cama para dormir, mas aqui no museu - nessa casa que é um museu - nós não podemos deitar na cama, não podemos sentar na cadeira e também não podemos ficar colocando a mão nas coisas porque está vendo essa cadeira? Esse assento é feito de palha - é uma palhinha - só que essa palhinha tem mais de 100 anos, ela é muito antiga! Aí, se todo mundo ficar colocando o dedo na palhinha, ela vai furar, ela vai estragar. E se estragar sabe o que eu vou fazer? Eu vou levar um tempão para consertar, muito tempo mesmo. Vou ter que pegar essa cadeira e guardar, e quando seus amigos voltarem aqui no museu vão falar "- Aquele museu é muito feio, não tem nada para ver! Eu passo por lá e não tem nada!". E eu vou ter que falar "- Ah, é porque o seu outro amigo veio aqui e estragou a cadeira, por isso que eu e o Luciano, que é o nosso amigo também [segurança que se aproximou no momento em que as crianças tocavam nos objetos do acervo], ficamos tomando conta das pessoas e pedindo para não ficar encostando em tudo, só em algumas coisas que deixamos. Mas vamos lá... (Caderno de Campo - Museu Casa de Rui Barbosa).

Outra forma que trabalho isso é falar que os objetos são tão antigos que para eles ficarem bem ali nós passamos alguns produtos que podem dar alergia e, às vezes, isso funciona melhor [do que explicar que o objeto pode estragar] (Entrevista-Maria Luiza / Mediadora do Museu Casa de Rui Barbosa). 
Dentro do Museu não era possível que as crianças se locomovessem de modo livre, com autonomia e rapidez. Brincadeiras que demandavam a atenção foram realizadas a partir da observação do acervo e as crianças eram estimuladas a expressar verbalmente suas impressões. No passeio pelo Jardim Histórico, as crianças puderam explorar a natureza com maior autonomia e mobilidade. O único aparato/dispositivo disponibilizado e utilizado durante a visita foi um livro de literatura infantil, da autora Ana Maria Machado, que pertencia à coleção da Biblioteca (BIMM).

No Museu de Arte do Rio, todos os espaços eram explorados com as crianças - pátio, terraço, as exposições e, até mesmo, a reserva técnica que era exposta ao público por ser uma sala em redoma de vidro. As exposições mais visitadas com as turmas de Educação Infantil foram a "Dja Guata Porã" e "Dentro". Nas observações realizadas, a exposição fotográfica "Feito poeira ao vento" foi visitada apenas duas vezes.

As exposições do ano de 2017 foram concebidas, em geral, de forma e altura adequada para que crianças e adultos tivessem acesso e visualização do acervo. Na exposição fotográfica "Feito poeira ao vento" apenas algumas obras estavam um pouco altas para que as crianças visualizassem.

A busca pela acessibilidade a diferentes públicos (não só o infantil) é um trabalho da Gerência de Educação que, constantemente, tem a tarefa de negociar com a equipe de curadores e museólogos alguns aspectos na concepção das exposições. Quando essas ações são inviabilizadas, buscam criar percursos expositivos que contemplem uma imersão mais sensorial na exposição para o público infantil e outros públicos que necessitem de recursos de acessibilidade.

Temos dois pontos: (i) Desde que o museu abriu experimentamos, de várias formas, a participação da equipe da Gerência de Educação no processo de concepção da exposição. Algumas experiências deram certo, outras nem tanto. Então, não está na mão da Gerência de Educação pensar a exposição, depende muito do curador que vai montar (...). Quando isso acontece [inacessibilidade], a experiência com a exposição tem que se dar de outra maneira. (ii) Não fazemos adaptação como, por exemplo, (até fazemos, mas é eventualmente) um quadro de pintura, não temos aquela pintura em relevo para um visitante com deficiência visual. Procuramos provocar experiências com aquele quadro ou realizamos adaptações no sentido de mapear uma exposição identificando o que é possível ser tocado. Nem todas as obras podem ser tocadas, mas, às vezes, tem uma escultura em que é possível tocar (não por todos os visitantes) e criamos um percurso tátil com alguns visitantes e grupos específicos (Entrevista - Clarisse/Educadora de Projetos do Museu de Artes do Rio).

Os amplos espaços expositivos do Museu eram utilizados de forma distintas pelos mediadores que buscavam estimular o prazer, a brincadeira, o movimento e a fantasia, acolhendo a vitalidade das crianças. Influenciados pela temática da fauna brasileira da exposição "Dja Guata Porã”, foi possibilitado que as crianças 
saltassem, pulassem, corressem, rastejassem, engatinhassem, imitassem sons e gestos de diferentes animais, dentre outros movimentos, nas galerias. $\mathrm{Na}$ exposição "Dentro", constituída por uma instalação com muito espaço livre, tapetes e objetos acolchoados, os mediadores utilizavam o corpo e um grande tecido azul para propor diferentes movimentos que possibilitavam interagir como o espaço, como rolar, saltar, pular, correr, mergulhar. Na exposição fotográfica "Feito Poeira ao vento", o espaço amplo e as temáticas das obras também proporcionavam essa interação e uma forma diferenciada de ver e estar no museu. Entretanto, essa não foi uma prática adotada pelos educadores (mediador e professores) no momento da visita, que teve como proposta, em sua maior parte, o diálogo e a observação.

Alguns aparatos/dispositivos eram utilizados pelos mediadores, de forma a estimular a multissensorialidade nas atividades que desenvolviam com grupos de Educação Infantil, como: um grande tecido azul para dinâmica de entrosamento na chegada do grupo e referência ao MAR; croqui do espaço expositivo em papel para que as crianças desenhassem suas expectativas sobre o que encontrariam no museu; livros de contos indígenas; material para plantação (pequenos potes, sementes, algodão e borrifador de água); instrumentos musicais indígenas; imagens de animais feitos de pinturas indígenas com diferentes texturas; televisores que exibiam vídeos de alguns rituais e do cotidiano de diferentes aldeias; baú com pequenos objetos (bonecos indígenas, conchas, sementes, chocalho, colar indígena) para contação de história, coco com cascas secas dentro para que as crianças sentissem cheiros etc.

\section{5.}

\section{Programas, atividades e metodologias}

A apropriação da experiência em museus pelas crianças consiste em um processo que envolve a dimensão racional e sensível, de assimilação de sentidos e significados sobre o patrimônio cultural musealizado (tangíveis ou intangíveis). Considerando que as crianças devem ser tocadas por essa experiência, a literatura aponta ${ }^{55}$ o quanto é importante que os programas e atividades destinadas a esse público tenham como alicerce metodologias que priorizem a experimentação, jogos e brincadeiras nos diferentes momentos da mediação, até mesmo e, principalmente, nos espaços expositivos.

55 Shaffer (2015); Moura (2011); Oliveira (2011); Leite (2011); Carvalho e Lopes (2016); Fallon e Chavepeyer (2013). 
Nesse sentido, Leite (2011) também destaca a necessidade de exploração das diversas áreas que os museus podem dispor, inclusive externas, para o desenvolvimento de brincadeiras, possibilitando e respeitando a rapidez na associação de ideias, os interesses pelo acervo e as transgressões caraterizadas pela vontade infantil de soltar o olhar e reverter a ordem das coisas. A autora considera igualmente importante, na relação com o espaço expositivo, a estratégia de utilização de jogos e brincadeiras que exijam também uma maior concentração e percepção do todo. Essas brincadeiras podem envolver formas únicas de movimentação que demandam mais tempo de observação por parte das crianças, algum nível de concentração e um exercício permanente de aproximação e distanciamento, provocando outras formas e ângulos de ver as exposições.

A perspectiva teórica de Vigotski (2009; 1998) enfatiza o papel da brincadeira no modo como a criança desenvolve sua atividade criadora de absorver e reelaborar seu conhecimento sobre o mundo. Para o autor, cada período da infância possui uma forma característica de criação que está estritamente ligada ao desenvolvimento e ao amadurecimento da criança. E, já na primeira infância ${ }^{56}$, é possível identificar os processos de criação que são melhor expressados em suas brincadeiras. $O$ autor defende que a imitação também se faz presente nas brincadeiras, onde as crianças reproduzem muito do que viram e viveram em suas experiências anteriores. Todavia, salienta que a imitação nunca ocorre exatamente como aconteceu na experiência. A brincadeira não é um simples processo de imitação ou recordação, há uma reelaboração criativa das impressões vividas e, a partir da combinação criativa das impressões, ocorre a construção de uma nova realidade pela criança para responder às suas aspirações e anseios.

No que se refere às atividades e programas desenvolvidos com jogos e brincadeiras buscando ações mais dinâmicas e atrativas para os diferentes públicos nos espaços expositivos, é fundamental que não se esvazie um dos papéis sociais dos museus - apresentar os objetos de cultura de forma crítica, estimulando o diálogo entre objeto e público. Carvalho e Porto (2013) concordam com essa perspectiva ao analisarem o quanto o êxito das ações educativas em museus está atrelado ao entendimento do público como sujeito crítico:

O sucesso das atividades oferecidas depende de vários fatores, mas, quando o museu é tomado como território (socialmente praticado), patrimônio (socialmente construído), o desdobramento das ações, apesar de planejado, pode envolver

\footnotetext{
56 "Em seus trabalhos, Vigotski refere-se a diversas idades: primeira infância, que seria a criança até três anos, e a idade pré-escolar, que seria a criança acima de três e até seis ou sete anos. (Nota da Tradutora)". (VIGOTSKI, 2009, p.16).
} 
transformações sugeridas pelos participantes no sentido de enriquecer os modos de ver e sentir o que se apresenta (CARVALHO e PORTO, 2013, p. 149).

Refletindo sobre a potencialidade na forma de apreensão do mundo na infância, Dewey (2002) enfatiza que, quando o conhecimento sofre modificação para retirar fases consideradas demasiado difíceis e reduzir as dificuldades da criança, é comum que aspectos importantes e com maior valor na lógica de investigação sobre as coisas do mundo sejam eliminados. O caráter provocador e desafiante do conhecimento é obscurecido e sua função organizadora desaparece. "Ou, como se costuma dizer, os poderes de raciocínio da criança, as faculdades de abstração e generalização, não são adequadamente desenvolvidas" (DEWEY, 2002, p.174). Qualquer assunto, quando apresentado de modo subtraído da experiência, é esvaziado do seu valor lógico e se transforma em substância só para a memória. Nesses momentos, onde a lógica da criança é enganada, são adquiridos resíduos de conhecimento insípidos e de lugarescomuns daquilo que um dia ganhou "vitalidade de conhecimento" nas gerações anteriores, pois, alguém formulou um saber, com base na experiência do que outras pessoas viveram, em outro tempo.

Ao se propor atividades nos museus para a audiência infantil, é preciso considerar que seu tempo é outro, diferente do adulto, mas capaz de compreender as coisas que a cercam. Em relação ao respeito do tempo e do movimento ágil da criança, é importante estar atento para que não se confunda com a pressa e superficialidade consumista da contemporaneidade. $O$ respeito a essa especificidade da criança é compreendido a partir do reconhecimento da rapidez de associação das ideias, das possibilidades de sensibilização com o espaço, com a rapidez associada à transgressão ligada a vontade de soltar o olhar que muitas vezes é prendido por regras. Conforme exposto, jogos e brincadeiras são atividades que devem compor as propostas voltadas ao público infantil. Oferecer esse tipo de atividade, não significa interromper o tema que está sendo explorado, investigado e construído para passar para uma nova atividade desarticulada de sentidos. A temática do conhecimento que está sendo explorado deve estar presente mesmo nas "brincadeiras mais agitadas" (LEITE, 2011).

Também refletindo sobre as propostas de atividades para o público infantil nos museus, Oliveira (2011) alerta para o fato de que a especificidade de receber crianças nos espaços expositivos não restringe a mediação e atividades propostas 
pautadas somente na concepção hands $o n^{57}$. As experiências museais não devem se restringir à manipulação de objetos. Para a autora, museus são, ou deveriam ser, espaços profícuos para a educação cultural das crianças e para o fortalecimento e expansão da imaginação infantil. Contudo, os educadores (da escola e do museu), por vezes, não percebem essa dimensão do conhecimento que pode estar presente nos encontros e nas experiências das crianças com a arquitetura museológica e com os objetos que compõem o acervo das exposições.

Em relação à atividade de mediação, Oliveira (2011) considera que, para que as crianças possam admirar e se interessar pelo conteúdo do museu, é preciso compreender que discursos e percursos expositivos extremamente lógicos e racionais deixam pouco espaço e tempo para o devaneio, para a emoção do encontro. Nesse sentido, é preciso ainda mais atenção para a não restrição de sentimentos e interpretações que as crianças conseguem articular e expressar. Insistir fortemente nas explicações diretivas e monológicas sobre o acervo pode acabar por reduzi-lo a suas dimensões técnicas, "privando a criança fruidora daquele algo a mais que gera a emoção, a admiração, o espanto" (OLIVEIRA, 2011, p. 321). Isso não significa negar a esse público as informações sobre o museu e suas obras. O que a autora propõe é a oportunidade para que as crianças, no espaço e tempo (respeitado), no encontro com a arquitetura e com o acervo museológico, possam viver a experiência estética de se colocar em jogo. Ou seja, que nesse encontro as crianças possam ser tocadas pelo que o museu expõe, pelo que e como é oferecido ao deleite.

As possibilidades de programas e atividades a serem desenvolvidas com o público infantil nos museus e centros culturais são inúmeras e variam conforme a estrutura de cada instituição. Não há uma "forma correta" para bem receber as crianças. Entretanto, Fallon e Chavepeyer (2013) apontam como uma boa prática encarar esse trabalho como um processo constituído na experiência dos próprios educadores dos museus aliado a estudos específicos sobre a infância.

Não há fórmula mágica para receber os pequenos no museu, é um «laboratório» que evolui de uma experiência para outra, como fazem esses pequenos exploradores que ousam descobrir o mundo. Com eles, o que conta é o encontro: seja você mesmo com sua sensibilidade, confiando em si mesmo e na capacidade dos pequenos de apreciar as obras. E para a prática evoluir, ter curiosidade sobre

\footnotetext{
${ }^{57}$ Modalidade de interação em museus que consiste na "interatividade manual" do público com o objeto, fenômeno ou ideia expostos. Por vezes, a ideia de "hands on" assume facetas negativas, marcada pelo recurso excessivo a experimentos, ou pelo uso de repetições de gestos mecânicos que tende a envolver os visitantes em uma interação mecânica e restrita. Ver mais em: WAGENSBERG, Jorge. Cosmocaixa. El museo total. Por conversación entre Arquitectos y museólogos. Barcelona: Sacyr, 2006.
} 
o desenvolvimento da criança (FALLON e CHAVEPEYER, 2013, p. 12-13, tradução da autora).

No Museu Casa de Rui Barbosa, embora não saibam mensurar quando, exatamente, começou a programação específica para o público de Educação Infantil, a historiografia sobre o Museu Casa de Rui Barbosa realizada por Albernaz (2006) revela que foi em 1972 que teve início um programa sistemático de visitação escolar, criando uma linha de atuação própria para o desenvolvimento de atividades educativas. Analisando os estudos da autora, é possível verificar que a oferta das ações educativas para esse público surgiu no período compreendido entre 1972 e 1990 - época do "boom educacional, quando a equipe se expandiu e se voltou para a criação de uma proposta diversificada metodologicamente, direcionada para públicos diferenciados" (ALBERNAZ, 2006, p. 12).

Historicamente, o projeto educativo desenvolvido especificamente para o público de Educação Infantil possui parceria com a BIMM (Biblioteca Infantojuvenil Maria Mazetti) e tem como objetivo promover a memória afetiva sobre o local e contribuir para a experiência cultural das crianças. A museóloga da Casa de Rui Barbosa também esclarece o que a Instituição pretende provocar nas crianças com o trabalho desenvolvido:

Queremos estimulá-los a ter prazer para que fique na memória afetiva. Que voltem, que eles peçam aos pais para trazê-los no fim de semana e, quando crescerem, venham aqui por conta própria. Nossa vontade é estimular a frequentar lugares como esse e que eles tenham uma experiência cultural muito agradável aqui (Entrevista - Francisca/ Museu Casa de Rui Barbosa).

Duas museológas, em parceria com a BIMM (que possui duas servidoras de nível médio com formação em Biblioteconomia) e os estagiários da Instituição são responsáveis, simultaneamente, pela elaboração e pela realização das ações educativas com o público infantil.

Os mesmos que planejam são os mesmos que executam [referindo-se à equipe]. Os estagiários executam, mas também participam da elaboração e das reuniões (...). Acho legal lidar com estagiários porque é uma faixa etária que está acostumada a usar muitos recursos tecnológicos, ver muitos jogos, muitas séries e dessas coisas eles tiram uma criatividade imensa. Nesse sentido, eles têm colaborado muito conosco, na criação de atividades diferentes e mais lúdicas dentro do Museu (Entrevista - Francisca/ Museu Casa de Rui Barbosa).

O espaço da Casa é mais priorizado nas visitas com o público de Educação Infantil do que, propriamente, o conteúdo que está em exposição. A observação no Jardim também é explorada.

Como são menores, priorizamos alguns espaços (...) até porque têm objetos interessantes que eles curtem como uma cadeira que vira escada; (...) um mataborrão que falamos para eles como se escrevia com pena e não com caneta, a sala de música é um espaço que eles adoram porque tem o teto decorado e deitamos com eles no tapete para olhar. $O$ banheiro é um espaço bem legal também porque 
não era comum ter banheiro dentro de casa então contamos isso e eles ficam um pouco espantados e a cozinha, porque tem o fogão a lenha. Dessa forma, eles visitam a Casa toda, mas detemos mais tempo em alguns espaços em que conseguimos fazer um trabalho mais diferente com eles (Entrevista - Francisca / Museóloga)

Têm dias que trabalhamos muito no Jardim a observação de como as árvores são diferentes - têm árvores que crescem para cima, têm árvores que são mais baixinhas, têm árvores que precisam do carreiro para crescer. Vemos que as árvores são diferentes, as plantas são diferentes, assim como nós - somos diferentes - mas todos são importantes. (Entrevista - Maria Luiza/Mediadora)

Os alicerces metodológicos da visita são o diálogo, observações e brincadeiras (de achar/adivinhar). Na visita observada, a contação de história, primeira atividade realizada, já solicitava a participação das crianças para descobrir qual era o personagem misterioso do livro. Nessa primeira etapa, as crianças participavam ativamente. A segunda etapa da visita - visita mediada pelos aposentos da Casa de Rui Barbosa - também se baseava no diálogo que buscava a observação e participação das crianças para compreender diferenças entre uma casa antiga e as casas de hoje. Além do diálogo, algumas brincadeiras e desafios eram propostos para as crianças com o intuito de achar peças específicas do acervo em meio à exposição.

Mediadora: Nessa sala tem um leque parecido com esse aqui [aponta para o leque do acervo exposto em uma vitrine]. Eu quero ver quem vai achar esse leque. Tem algum leque aqui? [crianças procuram animadas].

Criança: Eu achei aqui! [apontando para o objeto pintado em um quadro].

Mediadora: Ah! Menina sagaz! Olha o leque gente, ela achou! É o mesmo leque que a Dona Maria Augusta está na mão. Está lá na vitrine, é lindo esse leque. Ele é feito de plumas. Vocês sabem o que é? (Caderno de Campo - Museu Casa de Rui Barbosa).

A terceira etapa da visita ocorria no Jardim Histórico. Nesse momento, a mediadora passeava com as crianças pelo jardim contando algumas curiosidades e propondo mais "brincadeiras de achar".

Mediadora: Vocês sabem que esse jardim é muito especial? Ele é um jardim histórico porque ele é muito antigo. Têm árvores aqui que foi o Rui Barbosa que plantou. Estão vendo essa árvore grandona aqui no meio? Ela tem um nome diferente. Quem adivinha?" (...). Aqui perto tem uma escultura que é uma águia comendo uma cobra, quero ver quem vai achar aonde está! [crianças circulam pelo jardim correndo, animadas e acham a estátua] (Caderno de Campo - Museu Casa de Rui Barbosa).

Já a Casa da Ciência da UFRJ não possui um programa/projeto específico para grupos de Educação Infantil. Afirmam receber todos os públicos, mas potencializam a recepção ao público de E.I a partir de adaptações de linguagem e desenvolvimento de atividades específicas como teatro e oficinas. Com o trabalho desenvolvido pretendem incitar o interesse pela ciência, pela arte e pela cultura, estimulando a curiosidade pela descoberta de novos conhecimentos. 
Estimular a curiosidade científica, amor à cultura e à arte, ampliação de conhecimento, de vocabulário, de curiosidades - tudo! Todas as possibilidades que um espaço cultural e interativo tem que estar sempre aguçando (...). Costumo dizer que se a criança sai daqui com uma pergunta, ela já está sendo bem atendida - ela sai daqui com aquela informação e depois ela quer desdobrar e aprofundar o tema - esse é o nosso papel! (Entrevista - Paula/Chefe da Seção de Educação)

A elaboração das ações educativas a serem desenvolvidas com o público infantil são desenvolvidas pela equipe da Seção de Educação em parceria com a Divisão de Programação (Setor da Casa) e com as instituições parceiras de cada exposição recebida. Os profissionais que realizam a mediação com o público escolar também são os funcionários da Seção de Educação e os mediadores que, geralmente, são bolsistas de extensão de áreas diversificadas de graduação da UFRJ.

Alguns aspectos são priorizados no momento da visita com os grupos de Educação Infantil. Segundo a chefe da Seção de Educação, há uma preocupação em elencar alguns elementos para diminuir o percurso, adaptar a linguagem para compreensão, ter a sensibilidade para perceber o que atrai e o que afasta 0 interesse das crianças.

Não dá para você fazer a mesma abordagem com um público muito jovem - eles cansam e sabemos que a atenção da criança é menor. Eles são mais novinhos então tem não só adaptação de percurso como de linguagem e de abordagem. Teve um grupo em que uma menina ficou com medo dos quadros [de Portinari] que tinham a ver com espantalhos, seca e morte (...). Então tivemos que ter a sensibilidade, na hora, para lidar com isso e saber discriminar qual era a melhor forma de conduzir a visita. Isso vai muito da sensibilidade de quem está atuando ali como mediador (...). A mediação tem que ser uma interlocução - não de respostas - de instigação, de curiosidade, de troca (Entrevista - Paula/Chefe da Seção de Educação).

A principal metodologia observada na exposição "Aedes que mosquito é esse?" foi o diálogo que os mediadores tentavam estabelecer com as crianças (que estavam resistentes pela timidez). Percebendo a reserva das crianças, ofereciam auxílio no uso dos aparelhos tecnológicos e instrumentos científicos presentes nos vários módulos da exposição. Também estimulavam a brincadeira exploratória de "caça ao foco" com o uso de tablets oferecidos pelo museu.

$\mathrm{Na}$ exposição "Portinari e o Meio Ambiente", o alicerce metodológico das visitas mediadas era o diálogo entre mediadores, crianças e professores, onde todos eram estimulados a trocar suas interpretações e sensações suscitadas pelas obras do artista. O conteúdo da exposição, que relacionava as obras do pintor à temática da natureza e do meio ambiente, era o foco da mediação. Relatos das experiências vividas pelas crianças, impressões e opiniões sobre o tema delineavam a visita. A exposição era composta por muitos quadros e nem todos 
eram contemplados, o roteiro ocorria, principalmente, pelos quadros que eram alvo de interesse das crianças.

A interação com pares e adultos era estimulada durante todo o percurso da visita, e, por vezes, a interação com o espaço do Museu era tolhida ao solicitarem que as crianças sentassem em frente à cada obra, evitando a livre circulação. Também não foi estimulado (pelos mediadores) e nem permitido (pelos professores) a interação com os equipamentos audiovisuais presentes na exposição. Ao final do percurso expositivo, em um de seus últimos quadros "Dança de Roda" - as crianças eram convidadas a fazer uma releitura artística da obra a partir da escolha de uma música da preferência do grupo. A atividade tinha como metodologia a observação do quadro e a escolha de uma música pelas crianças, que era cantada e dançada como ciranda por todos.

Outra atividade desenvolvida nessa exposição foi a oficina, realizada de duas formas: (i) no início da exposição, desenho em cartolina do contorno das mãos das crianças, recortado formando uma "pulseira", com colagem de pequenos corações de papel reutilizado. Enquanto as crianças decoravam sua arte, os mediadores aproveitam o momento para conhecer, dialogar e interagir com o grupo, já iniciando o tema da exposição; (ii) ao final da exposição, em um ambiente amplo e livre (apenas com alguns pufes), as crianças eram convidadas a fazer um desenho inspiradas nas obras que viram durante a exposição.

Leite (2005) questiona essa prática comum nos museus - solicitar que as crianças façam um desenho daquilo que mais gostaram ao final da visita. Reconhece que o desenho, assim como demais formas de expressão, é polifônico e múltiplo. Alerta que, ao longo da vida, em diferentes grupos e comunidades, ocorre o contato com diversas linguagens, algumas sendo mais frequentes e preferidas do que outras. Entretanto, ainda é uma prática recorrente a solicitação de desenhos quando se trabalha com crianças, por ser considerado uma linguagem "tipicamente infantil". É importante compreender que, nas exposições, o processo de apropriação e produção recai sobre possibilidade de ampliação dos acervos interiores, de material variado para reelaboração a partir do contato com o conteúdo expositivo. A garantia de que a criança seja autora e tenha assegurado seu processo de criação se dá, principalmente, na possibilidade de interpretação e troca de saberes e impressões sobre o que vê e sente. Reconhecendo essa perspectiva da capacidade criativa da criança nos museus, entende-se que "mais do que fazer oficinas pedindo que as crianças desenhem, na melhor das hipóteses, "a seu modo", aquilo que contemplaram, seria importante nos 
preocuparmos em investir na continuidade de respostas ricas em experiência visuais, estéticas e de criação.". (LEITE, 2005, p.49).

Essa perspectiva teórica que prioriza a continuidade da experiência, em detrimento de uma atividade artística desconexa, coaduna com a perspectiva de Dewey (2010), que aponta o princípio da continuidade como uma qualidade da experiência que proporciona a construção de conhecimento para o sujeito. Logo, pensar mais amplamente os espaços de criação destinado às crianças nos museus é mais significativo para uma formação estética e cultural do que oferecer papel e lápis com o argumento de estímulo à criatividade. Na exposição observada na Casa da Ciência, a própria escolha de materiais como lápis e caneta ao invés de explorar os elementos naturais, por exemplo, já demonstra uma falta de reflexão/conexão sobre essa prática.

O Museu de Arte do Rio também afirmou não possuir um programa/projeto educativo específico para o público de Educação Infantil. Os grupos são recebidos dentro do "Programa de Visitas Educativas" que funciona desde a abertura do Museu, em 2013. A Instituição pretende provocar no público escolar, através desse Programa, experiências de criação.

Não acreditamos que a nossa função de educador seja transmitir conhecimento das exposições, nem traduzir a obra, nem dizer o que a curadoria queria dizer (...). Acho que apostamos muito na criação - que todos criam, não só o artista é o criador ali na obra, mas o educador também é criador, o público também é criador. Acho que se a visita apostar nos espaços de criação e de experiência, onde todos possam criar juntos, isso talvez seja a nossa expectativa. Queremos ter visitas em que as crianças tenham essa possibilidade de criar suas narrativas, pelas experiências delas, juntos - enquanto grupo (Entrevista - Clarisse/Educadora de Projetos).

O "Programa de Visitas Educativas" é composto por quatro eixos temáticos em que o professor/escola opta por um deles ainda no agendamento. Os eixos foram desenvolvidos com o intuito de possibilitar que, em uma única visita, pudessem ser percorridas as várias exposições que o Museu abriga concomitantemente. A Gerência de Educação entende que a curadoria do Museu tem uma narrativa e que as diferentes exposições dialogam entre si; portanto, visitar apenas uma exposição seria perder a potencialidade que o MAR apresenta. Os quatro eixos, independente das exposições, são temas de interesse do MAR e, desta forma, é possível trabalhar com qualquer um dos eixos em todas as exposições. Sobre esse aspecto, destacam a importância de a área da educação estar em constante diálogo com a área da curadoria, pois são práticas que devem caminhar juntas.

No Museu, todos os funcionários da Gerência de Educação estão envolvidos nas ações educativas, embora sejam os mediadores que preparam, em duplas, o 
que será desenvolvido. Não há um roteiro de visita que deve ser utilizado por toda a equipe: os mediadores têm autonomia para planejar as atividades. Os aspectos priorizados em cada exposição com o público de Educação Infantil também são distintos, variam conforme a percepção do mediador sobre as informações obtidas no agendamento e captadas no momento da visita.

Quando recebemos a incumbência de uma visita, olhamos para os materiais que temos e pensamos no que pode ser interessante para despertar uma nova perspectiva sobre as coisas que estamos tão acostumados a ver. Quando são grupos infantis podemos, por meio da nossa autonomia e da nossa inventividade, pensar em como pegar o mesmo material que usamos com outros grupos e fazer com que atendam ao público infantil também: são materiais como tecidos, baralhos lúdicos, lápis, caneta, papel, instrumentos musicais, barbante, bola, livros de artistas etc. A metodologia vai mudar no momento, obedecer ao fluxo daquele momento, vai obedecer ao emprego do material para construir a visita, vai passar pelo que está acontecendo. Planejamos a visita inteira, mas se acontece de ter uma criança que está com saudade da mãe, está chorando - é o contexto daquele momento. Ele [o contexto] é, muitas vezes, que vai ser nossa bússola de ação (Entrevista Abel/Mediador).

Segundo a educadora de projetos da Instituição, no "Programa de Visitas Educativas" nenhuma visita é igual à outra. Os educadores planejam cada atividade de acordo com perfil do grupo, cujas características são delineadas pelo que a Instituição chama de pré-visita (ou agendamento). Entretanto, os mediadores alertam que, algumas vezes, o processo é corrido e falho. Algumas escolas não retornam o contato dando as informações necessárias e o tempo que possuem para o planejamento é curto. Consideram que essas dificuldades prejudicam a melhoria do trabalho.

Nas visitas observadas com os grupos de E.I, foi possível perceber que as principais estratégias utilizadas pelos mediadores, para atuar junto às crianças, englobam o diálogo, a brincadeira e a exploração de diferentes formas de ocupar o espaço do Museu. O faz-de-conta, a leitura de imagens e a contação de história apresentaram-se de modo recorrente - do início ao fim das visitas - e despertavam 0 interesse das crianças. Alguns outros recursos também eram utilizados durante as atividades, como: figurino diferenciado para a contação de histórias (adereços de gênio, máscara de cavalo), um pequeno baú que guardava "tesouros" (colares, conchas, sementes, bonecos indígenas), instrumentos musicais, croqui com a maquete do Museu, dentre outros. Utilizando-se dessas diferentes estratégias, a mediação tinha como alicerce o diálogo e a troca entre o grupo.

A recepção aos grupos sempre começava por uma conversa no pátio (ou no terraço) para que os mediadores e as crianças pudessem se conhecer, identificar onde estavam, descobrir se já haviam visitado o Museu, conhecer as expectativas das crianças e entrar em um clima de aventura e descobertas. 
Carvalho (2016), ao analisar grupos escolares em espaços culturais, aponta a existência de uma "ritualidade da visita". Geralmente, essa ritualidade envolve uma série de regras que implica em uma tomada de seriedade e usurpação da espontaneidade do visitante, como: o controle, o policiamento da entrada, a obrigatoriedade de um percurso, a imposição de fronteiras estabelecidas para a apreciação das obras. Ainda na chegada aos museus, o "ritual" é frequentemente marcado pelo depósito das mochilas no guarda-volumes e pela roda de conversa inicial. Tais procedimentos podem ser compreendidos como o momento em que 0 aluno se despe, temporariamente, de alguns elementos indicativos de sua identidade, contribuindo para explicitar a condição de visitante em que se coloca ao entrar no museu. E, na roda de conversa inicial, é comum que sejam explicitadas as regras para entrar na exposição e o modo como a visita deve acontecer, evitando rupturas indesejáveis das normas.

A autora destaca que, por meio da análise dos rituais, podemos observar aspectos de como uma sociedade vive, pensa e se transforma. Eliminando o preconceito de ver os rituais apenas como fenômenos formais e desprovidos de sentido, pode-se entender também que, ao contrário, os elementos que entram no ritual fazem parte de um repertório usual, mas podem também ser reinventados, passíveis de mudança.

No MAR, foi possível observar que esse "ritual de entrada" sofreu mudanças significativas, buscando o entrosamento, o diálogo e a curiosidade das crianças ${ }^{58}$. Nenhuma visita era iniciada com normas ou regras de comportamento. Nessa recepção inicial ao grupo, no terraço do Museu, eram observados os elementos da paisagem da carioca e os mediadores apresentavam o MAR a partir de brincadeiras como "fazer eco" batendo palmas e observando o teto em formato de onda e com brincadeiras de dinamização com um grande tecido azul - também fazendo referência ao nome do museu. $\mathrm{O}$ uso do faz-de-conta para estimular a curiosidade sobre o que encontrariam no Museu apresentou-se como outra estratégia frequentemente utilizada.

\footnotetext{
Mediador: Será que tem como nadar nesse mar aqui?

Crianças: Não.

Mediador: Pior que tem! Vou mostrar para vocês como fazemos para mergulhar nesse mar. É o seguinte, presta atenção! Quando eu falar "já" nós vamos para baixo dessa água. Está bem? [mediador pega um grande tecido azul e abre para que cada criança segure na ponta, mergulha debaixo do tecido e volta]. No "já" hem! Vamos mergulhar: 1, 2, 3 e já! [as crianças mergulham para baixo do tecido e os mediadores também]. Volta para respirar, volta para respirar! [todos saem debaixo do tecido].
}

\footnotetext{
${ }^{58} \mathrm{Na}$ Casa da Ciência da UFRJ e no Museu Casa de Rui Barbosa não havia essa ritualidade no início da recepção aos grupos de E.I. Em geral, as visitas já começam na exposição ou com uma contação de história (no Museu Casa de Rui Barbosa).
} 
Cadê a onda? Cadê a onda? [as crianças agitam fortemente o tecido animadas e gargalhando]. Quem quer mergulhar de novo?

Crianças: Eu [respondem animadas e a brincadeira continua por um tempo no terraço do museu].

(Caderno de Campo - Museu de Arte do Rio)

Mediador: E agora, para entrarmos dentro do castelo [museu] e ver o que tem dentro dele, vamos precisar ter coragem. Vocês têm coragem?

Crianças: Sim!

Mediador: Já atravessamos o rio, fugimos do urso e atravessamos a caverna. Agora vamos ter que andar de barco de novo para ver o que vamos descobrir lá dentro. Segura o barco, vamos remando [crianças seguram o grande tecido azul e fazem de conta remar pelo museu].

(Caderno de Campo - Museu de Arte do Rio)

Na exposição "Dja Guata Porã" as crianças eram estimuladas a relatar o que observavam: identificavam e diferenciavam cores, traçados, tamanhos e desenhos indígenas. Ao mesmo tempo em que observavam, em geral explicitavam conteúdos sobre a temática indígena aprendidos na escola, na televisão ou em outras referências. Uma das atividades mais exploradas pelos mediadores era a contação de contos indígenas, sentados embaixo de uma árvore de sapucaia ${ }^{59}$. As crianças eram convidadas a participar trazendo narrativas com elementos conhecidos, como frutas, animais, sons, gestos, onomatopeias... e ajudavam no desenrolar/ desfecho da história, em uma construção coletiva. Brincadeiras mais agitadas também eram muito utilizadas, estimulando movimentos variados: as crianças corriam, deitavam, rolavam, caçavam e rastejavam, imitando sons e gestos de diferentes animais junto com os mediadores. A leitura de imagens (placas com pinturas indígenas da fauna brasileira, confeccionadas com diferentes texturas, possibilitando que as crianças criassem hipóteses sobre sons, formas de locomoção, cores) e o uso da música com diferentes instrumentos indígenas (crianças tocavam e estabeleciam relações do som com diferentes animais da floresta) eram recursos igualmente utilizados pelos mediadores.

Mediador 1: Agora, olha só, tem um bichinho que está presente aqui no castelo e o início dele é aqui. Que animal será? Será que é um elefante?

Crianças: Uma cobra/ O leão/ Um macaco.

Mediador 1: Será? Como é o barulho do leão? [crianças rugem]. Me disseram aqui que também é uma cobra. Quem disse?

Professora: Foi a Larissa.

Mediador 2: Como é o barulho da cobra? [crianças silvam e começam a imitar a cobra rastejando pelo chão].

Mediador 2: Podemos imitar com as mãos [as crianças continuam rastejando e os mediadores deitam no chão vão rastejando pela exposição junto com as crianças]. Mediador 1: Essa cobra também pode correr um pouquinho! Vamos levantar? [crianças e os dois mediadores vão passeando pela exposição, correndo, junto ao movimento da cobra pintada na parede. Os professores seguem correndo atrás um

\footnotetext{
59 Instalação artística de uma grande árvore artificial localizada dentro da galeria.
} 
pouco desesperados. As crianças correm e relatam o que veem dos elementos pintados e pendurados nas paredes de toda a exposição.]

(Caderno de Campo - Museu de Arte do Rio)

$\mathrm{Na}$ exposição fotográfica "Feito poeira ao vento" eram estabelecidos diálogos sobre o que identificavam nas obras: semelhanças e diferenças, cores, quantidade de objetos, elementos de preferência e as crianças reproduziram (por iniciativa própria) algumas letras do alfabeto em uma sequência de fotos. Em outra visita, um mediador propôs que as crianças circulassem pela exposição procurando um melão (presente em uma das fotografias) - fruta para alimentar a onça da exposição "Dja Guata Porã" em uma brincadeira de faz-de-conta.

$\mathrm{Na}$ exposição "Dentro", as crianças eram convidadas a relaxar a tirar os sapatos. Também exploravam diferentes movimentos com o corpo e os mediadores propunham várias brincadeiras, como: andar abraçado, andar em trio, andar no coletivo, andar de lado, deitar, rolar, dar cambalhotas.

Ao longo do trabalho de campo, foi possível observar diferentes ações e metodologias nos museus investigados. Dois deles (MAR e Casa da Ciência), mesmo não possuindo um programa ou projeto educativo destinado especificamente para a recepção ao público infantil, demonstraram que é possível adotar boas práticas para um trabalho que busca atender as especificidades desse público.

De modo geral, nas três instituições, os responsáveis por planejar as ações educativas com as crianças são os mesmos que executam - e trabalham em conjunto. Esse trabalho em equipe reflete na adoção de práticas que buscam a ludicidade, a inovação, a reformulação e a autonomia para adaptar cada visita à realidade do contexto que se apresenta diante dos diferentes grupos - diferentes infâncias - que frequentam seus espaços. Os educadores buscavam desenvolver as atividades de modo a respeitar os diferentes tempos, curiosidades, interesses e sensações que as crianças apresentavam.

Por parte das três instituições havia a preocupação em adaptar o percurso expositivo de forma a atender aos interesses e despertar a curiosidade das crianças. Respeitando à especificidade de cada instituição, os objetivos dos trabalhos realizados coadunam na perspectiva de buscar oferecer às crianças uma experiência cultural que fosse capaz de estimular a curiosidade e a capacidade de criação, despertando uma memória afetiva com os espaços de cultura.

As principais estratégias e metodologias de trabalho observadas foram o diálogo, a observação, as brincadeiras e o estímulo à interpretação, à 
comparação, à imaginação e a troca de impressões com os diferentes agentes envolvidos no momento da visita (pares, mediadores, professores).

Outro aspecto investigado, no que se refere aos programas e atividades desenvolvidas com o público de E.I, foi se as três instituições adotavam alguma avaliação sobre suas ações.

No Museu Casa de Rui Barbosa, segundo a museóloga entrevistada, a avaliação das ações educativas ocorre por meio de reunião interna e questionários avaliativos respondidos pelos professores. Ressalta que ainda não possuem uma ferramenta de avaliação destinada ao público infantil, apesar de se configurar como um desejo da instituição. Outro aspecto mencionado foi a dúvida sobre a real efetividade dos questionários preenchidos pelos professores, pois, geralmente, este instrumento é respondido de forma breve ao final da visita, e não há críticas ou apontamentos que orientem na redefinição das práticas desenvolvidas no Museu. A tentativa de enviar a avaliação via e-mail para que fosse respondido com mais calma não obteve êxito, pois o retorno foi muito baixo. A reformulações das atividades oferecidas ocorre conforme a equipe percebe que algo não funciona ou quando sentem a necessidade de mudanças. Não há uma periodicidade na tarefa.

$\mathrm{Na}$ Casa da Ciência, a avaliação é realizada através de um formulário online enviado aos professores. As respostas são analisadas pela Instituição, gerando um relatório e perspectivas de mudanças nas atividades. Não há uma avaliação sistematizada com o público infantil, mas buscam, ao final da visita, propor uma roda de conversa para que expressem suas impressões. Na fala dos mediadores, essa atividade de avaliação está mais atrelada à aferição do conteúdo da exposição apreendido pelas crianças do que uma ferramenta de avaliação do trabalho desenvolvido com o público infantil.

De toda forma, alguns entrevistados declararam que a Seção de Educação fica atenta às atividades de mediação junto ao público infantil para a adaptação ou troca de alguma ação que julguem inadequada. A reformulação das atividades ocorre com frequência - a cada troca de exposição - e, também, sempre que julgam alguma mudança necessária.

O Museu de Arte do Rio, até o final do período de realização do campo (2017), não possuía avaliação das atividades desenvolvidas junto ao público infantil. No projeto "Partiu MAR"60, daquele ano, pela primeira vez foi aplicado um questionário para que os professores avaliassem as ações. Portanto, ainda não

${ }^{60}$ Projeto educativo dentro do "Programa de Visitas" que disponibilizava um ônibus para as escolas públicas do Rio de Janeiro. 
havia uma análise desse material e nem seus possíveis desdobramentos na prática.

Quanto à reformulação das atividades oferecidas, a Educadora de Projetos do MAR declarou que ocorre a cada nova exposição. Além desse aspecto, sempre que sentem necessidade de mudar suas práticas, a Gerência de Educação e os mediadores estão abertos a esse movimento. Consideram que nenhuma visita é igual a outra, pois os mediadores modificam o percurso a partir das informações obtidas no agendamento e no momento da visita.

De acordo com Marandino (2008), a avaliação nos museus é uma prática fundamental nos processos de comunicação e educação. Para a autora, a prática avaliativa nas instituições museológicas, de forma geral, deve ser compreendida enquanto levantamento sistemático de informações úteis à tomada de decisão.

Cazelli e Coimbra (2007) refletindo sobre a avaliação das ações educativas presentes na relação museu e escola, concordam que a adoção de uma prática de autoavaliação dos museus, junto às escolas que visitam seus espaços, pode contribuir para melhor direcionar as ações que permeiam a relação entre as duas instituições. Diante dos desafios que a educação enfrenta hoje, consideram fundamental uma cooperação entre diferentes instituições educativas. Acreditam que escola e museu podem atuar juntos na formulação e execução de um trabalho onde as especificidades da educação formal e não formal, que ocorrem em cada uma dessas instituições, sejam colocadas a serviço da construção de uma sinergia entre ambas. Destacando o aspecto mais flexível, lúdico e de deleite, consideram que a função educativa do museu se apresenta de modo a contribuir no desenvolvimento da motivação intrínseca para o aprendizado. Já as escolas, são as instituições sociais com maior capacidade de promover a sistematização com continuidade do trabalho educativo.

Respeitando então a natureza educativa de cada instituição, os autores consideram que a avaliação no contexto museal, onde a experiência do visitante é importante, não deve priorizar, exatamente, o conteúdo assimilado ou aprendido, mas sim as consequências que a visita acarreta. Marandino (2008) também enfatiza a importância de usar os processos de avaliação de forma a conhecer qual a leitura e experiência do público. Aponta alguns recursos eficientes na coleta de dados em um processo de avaliação em museus, como: filmagens de grupos, entrevistas individuais com o público ao final da visita, questionários anônimos, grupos focais, entrevistas com membros da própria equipe, observação da exposição e de grupos, exame dos 'livros de ocorrência', reuniões de equipe, entre outros. 
Examinando as formas de avaliar as ações desenvolvidas com E.I nas três instituições observadas na pesquisa, foi possível aferir que o uso de questionários aos professores que visitavam os museus com suas turmas se mostrou o modo de avaliação mais recorrente. Nenhuma tentativa de avaliar a experiência vivida pelas crianças havia sido implementada.

Foi possível perceber que os mediadores dos três espaços utilizam recursos que, na verdade, podem ser entendidos com processos de avaliação durante a visita, como aferir a apreensão do conteúdo ou medir o interesse e modificar a prática de mediação. Nesse sentido, os estudos de Marandino (2008) sobre a atividade de avaliação nos museus, destacam como os mediadores podem contribuir de forma significativa nos processos avaliativos. Podem colaborar, diretamente, na coleta de dados aplicando os recursos avaliativos, bem como, apresentando de forma sistematizada suas impressões acerca da experiência com o público.

\section{6.}

\section{A formação de mediadores para atuar com o público infantil}

Marandino (2008) considera que uma das principais funções sociais dos museus é a formação do indivíduo. As ações realizadas pelas instituições museológicas adquirirem seu caráter educativo por meio da comunicação de seus acervos. Na concepção da autora, os mediadores dos museus assumem importante papel no que se refere à apropriação dos saberes pelos diferentes públicos. "São eles que concretizam a comunicação da instituição com o público e propiciam o diálogo com os visitantes acerca das questões presentes no museu, dando-Ihes novos significados" (MARANDINO, 2008, p.28). Para tanto, destaca que o cumprimento dessa tarefa implica que os setores educativos dos museus possam contar com mediadores adequadamente formados para tal atividade.

Lima (2018) aponta que a formação do mediador para uma atuação "ideal" é complexa e envolve diversos saberes desejados, como: os saberes da ciência de origem do museu; saberes relacionados a teorias de aprendizagem e da transposição didática; particularidades e objetivos da educação não formal; saberes sobre as questões socioculturais dos diferentes públicos que frequentam o museu e a escolha da linguagem adequada para cada público de forma a favorecer o diálogo; saber da história da instituição; saber interagir com os docentes presentes em uma visita escolar; o saber da conexão - que se refere a conectar diferentes espaços e atividades de uma mesma exposição; o saber da história da humanidade; o saber da expressão corporal; o saber da manipulação 
de aparatos e demais objetos e experimentos; o saber da ambientação (que se refere a conhecer características do ambiente da exposição, tais como luz, cor, estilo do mobiliário);o saber da concepção da exposição (que se relaciona com a discussão de que os mediadores deveriam participar dos processos de elaboração e montagem das exposições); dentre outros.

Diante de toda essa gama de saberes, a autora ressalta que é certo que a formação de um mediador é complexa, uma vez que exige que esse profissional mobilize diversos saberes em sua prática. Analisando alguns estudos sobre o papel da mediação na educação em museus, destaca que, apesar do consenso sobre a importância da "interface humana" nos percursos expositivos, ainda é escasso o investimento na avaliação e capacitação desses profissionais. Ademais, dificilmente as atividades de formação de mediadores incluem um suporte teórico adequado sobre a educação não formal em museus e teorias sobre as especificidades da comunicação de seus acervos.

Outro ponto a ser destacado sobre o papel e a formação do mediador é a frágil configuração no que tange ao reconhecimento desse profissional nas instituições museais. Marandino (2008) esclarece que são diversas as possibilidades de ação dos mediadores e, certamente, variam dependendo da instituição. Considera que a participação dos mediadores deve ocorrer desde o planejamento até a execução das atividades junto ao público. A situação ideal de trabalho é aquela na qual o mediador é compreendido enquanto parte da equipe do museu e planeja as ações em conjunto com os demais setores. Entretanto, a realidade que se apresenta é, em geral, a informalidade que costuma predominar nas relações de trabalho que, nem sempre, exige uma formação específica. São trabalhos temporários exercidos por jovens estudantes, de ensino médio ou graduação, que se dão através de estágios, de forma voluntária ou sem que haja um vínculo empregatício com a instituição (LIMA, 2018; CARVALHO, 2016, MARANDINO, 2008). Como reflexo dessa configuração, há uma rotatividade desses profissionais nas instituições e geralmente:

os mediadores não são envolvidos nas primeiras etapas de planejamento das atividades oferecidas pela instituição onde trabalham, não são treinados para analisar e avaliar os objetivos, impactos e resultados do seu trabalho e, por fim, raramente o conhecimento que esses sujeitos acumulam sobre público, assim como a avaliação que realizam sobre as estratégias de comunicação, são coletados e/ou valorizados pelos museus (LIMA, 2018, p.74).

Considerando esses aspectos apontados na literatura concernente a formação e atuação dos mediadores em museus, conforme exposto no quadro 2 (perfil dos entrevistados), foi possível aferir que a formação dos profissionais que 
atuam nas áreas educativas dos museus e centros culturais investigados nesta pesquisa transita entre estagiários de graduação e profissionais (CLT e concursados) de diferentes campos - Museologia, Biologia, Pedagogia, História, História da Arte, Cinema, Filosofia, Arte, Escultura, Letras, dentre outros. Constatar essa diversidade de saberes entre os profissionais dos setores educativos é um fator positivo - pensamentos e saberes variados, advindos de diferentes áreas, contribuem para um trabalho interdisciplinar. Entretanto, um dos "saberes dos mediadores" elencado por Lima (2018) - "saberes sobre as questões socioculturais dos diferentes públicos que frequentam o museu e a escolha da linguagem adequada para cada público de forma a favorecer o diálogo" - tem sido apontado por estudiosos da área como frágil na recepção ao público infantil. No momento de planejar e implementar as ações junto às crianças, algumas especificidades precisam ser conhecidas e consideradas pelos profissionais que atuam nesses espaços

De acordo com Shaffer (2015), os profissionais do museu que estudam a teoria educacional e exploram os estágios iniciais do desenvolvimento cognitivo, constroem uma base sólida para construir sua prática em contextos formais e informais ${ }^{61}$. E, seja nas salas de aula ou nas galerias, os profissionais serão capazes de usar esse conhecimento sobre a aprendizagem, o que é fundamental para projetar programas apropriados à cada faixa etária.

Satisfazer as necessidades sociais, emocionais, físicas e intelectuais das crianças que visitam museus é resultado de uma compreensão acerca da criança enquanto sujeito de/na aprendizagem. Salienta que é igualmente importante considerar a criança em um contexto complexo quando chegam aos museus, pois, claramente, não chegam desacompanhadas, mas com acompanhantes adultos, famílias ou grupos de pré-escola. Para a autora, educadores familiarizados com teorias de aprendizagem relacionadas à interação social - como a visão de Vigotski de que a aprendizagem está integralmente ligada à interação social realizarão atividades dentro do contexto dessas relações sociais, por exemplo.

Isto posto, busquei averiguar se os museus investigados desenvolviam alguma formação específica para que sua equipe recebesse o público infantil. Para tanto, indaguei às coordenadoras responsáveis pelas ações educativas se havia alguma formação interna e, em caso positivo, como ocorria. A questão

\footnotetext{
${ }^{61}$ Os termos "informal settings", "informal learning", "informal institutuions" são utilizados pela autora para se referir à educação que ocorre nos espaços não escolares, como museus e galerias de arte. Salienta que, no pensamento educacional do século XXI, a lacuna entre a aprendizagem informal e formal parece estar diminuindo.
} 
também foi direcionada aos mediadores que atuavam diretamente com as crianças.

No Museu Casa de Rui Barbosa, devido ao fato de possuir uma equipe reduzida, não há formação específica para receber o público infantil. As profissionais da área educativa (três museólogas) realizam o trabalho de mediação com os diferentes públicos que visitam o museu e, no que tange à formação dos estagiários de graduação, ocorre uma rotina de estudos sobre os conteúdos e história do Museu e o acompanhamento de algumas mediações feitas pelas museólogas. No momento em que os estagiários se sentem confortáveis, e quando as museólogas avaliam que os estudantes estão aptos, é iniciado o trabalho de mediação junto ao público infantil.

Outro aspecto a ser salientado sobre a formação dos mediadores no Museu Casa de Rui Barbosa é que a Instituição só possui estagiários de museologia. Segundo a museóloga responsável pelas ações educativas, isso ocorre porque "para orientar estagiário, tem que ter a formação no quadro. Fica difícil solicitar estagiários de outras áreas porque nós não temos pessoas [formadas em outras áreas] para orientá-los” (Entrevista - Francisca / Museóloga).

No momento de realização da pesquisa de campo, o Museu contava apenas com uma estagiária (graduanda de museologia que atuava há 1 ano e 7 meses no local) que confirmou que não havia formação específica na Instituição para receber o público infantil, e sim momentos de estudo sobre as especificidades do Museu, seguido de observações de visitas para diferentes públicos, incluindo o público infantil. $\mathrm{Na}$ entrevista com a mediadora, foi possível perceber a importância da experiência vivida e compartilhada com e pelos educadores mais experientes e o processo de ressignificação desse aprendizado para a criação de sua própria prática educativa.

Quando questionada se considerava suficiente o processo que passou na Instituição para receber o público infantil, a mediadora revelou sua insegurança no momento em que começou a desenvolver a mediação com crianças. Avalia que o conhecimento acerca do trabalho a ser desenvolvido com o público infantil é adquirido por meio da prática, com colegas mais experientes, e destacou também que, por interesse, conseguia sanar algumas dúvidas em seu curso de graduação (museologia).

Eu considero suficiente [a formação recebida] porque a graduação colabora com isso (...). Como tenho interesso pelo público infantil, em toda aula consigo puxar esse tema um pouquinho. Os professores me ajudam até para falar "Não, isso não tem nada a ver, sabe? Calma!" (...). A única coisa que, infelizmente, não foi possível, porque a equipe do Museu é muito pequena, foi ter mais tempo para fazer mais 
visitas junto com as pessoas que já têm experiência. Eu acho que isso iria me dar mais segurança (...). mas eu também não sei se eu fizesse mais visitas acompanhada isso iria resolver. Eu acho que acabamos pegando com a prática, não é?! (Entrevista - Maria Luiza/Mediadora).

Já na Casa da Ciência, todos os anos, a Seção de Educação promove o Curso de Formação de Mediadores, aberto ao público, que estabelece parceria com pesquisadores que vão à Instituição realizar palestras e oficinas sobre a temática da exposição e sobre educação em museus. Ao longo do ano, a cada nova exposição é também realizada uma atualização interna na formação dos estagiários, mas que contempla a participação dos demais funcionários (concursados da UFRJ) que atuam na Seção de Educação - mesmo que não trabalhem diretamente com a recepção ao público escolar.

$\mathrm{Na}$ entrevista com a responsável pela coordenação das ações educativas da Casa da Ciência, alguns pontos relacionados à formação dos profissionais e ao trabalho de recepção do público infantil foram igualmente elencados pela equipe do Museu Casa de Rui Barbosa: a compreensão de que o conhecimento acerca do trabalho a ser desenvolvido com as crianças é adquirido por meio da prática em uma aprendizagem cotidiana, a importância do compartilhamento de experiências pelos educadores mais experientes, a participação criativa dos mediadores no desenvolvimento de atividades voltadas às crianças e a dificuldade de realização do trabalho em decorrência da equipe ser reduzida.

Trabalhamos na formação dos mediadores [para atuar] com esse público: quais as necessidades, o que eles precisam, como deve ser essa abordagem etc. E durante o processo também passamos algumas informações para eles (...). Normalmente, atua junto a esse grupo quem tem mais habilidade, mais jeito, mas eles [estagiários] sempre entendem que tem que fazer uma adaptação de linguagem (...). Quando começa [a visita] estou observando e depois, se preciso, oriento eles. Isso é uma aprendizagem cotidiana (...). Na exposição Aedes quem idealizou e fez as oficinas foram os próprios mediadores. A partir de todo o trabalho que fazemos no curso de formação, eles elaboraram as atividades e nós viabilizamos - demos materiais, estruturamos o desenvolvimento de como fazer e organizamos tudo para que pudesse acontecer. Ficou bem bacana! (...). Nessas últimas exposições tivemos que apoiá-los mais devido a esse menor número [referindo-se ao corte das bolsas de estágio] (Entrevista - Paula / Chefe da Seção de Educação).

Na entrevista com três mediadores, que atuavam há 7 meses na Instituição, foi confirmado os dois processos de formação ocorridos ao longo do ano, o primeiro mais abrangente (Curso de Formação de Mediadores) e o segundo mais reduzido - para a exposição "Portinari e o Meio Ambiente". Na percepção dos mediadores, o Curso de Formação teve ênfase na recepção ao público infantil, pois havia uma preocupação com o vocabulário da exposição para as crianças pequenas "que ainda não possuem um entendimento mais elevado da realidade". Destacaram, também, a presença de sujeitos mais experientes (nesse caso, 
professores) no processo de construção do aprendizado sobre a prática educativa com crianças nos museus.

Carol: Nossa capacitação foi, praticamente, toda voltada para público infantil. Tivemos bastante experimentação com público infantil porque é um público, não mais complicado, mas, mais importante de atingir. Na teoria, é mais fácil você conversar com uma criança que já tem uma capacidade de entendimento mais elevada, então é mais fácil você passar a informação porque você já tem esse vocabulário para passar.

Andrea: Na parte [do curso de formação] sobre Educação Infantil pegávamos um tema da exposição e tínhamos que apresentar como se fosse para um público de 4 a 6 anos, sempre com o acompanhamento de alguns professores que estão acostumados com a situação (Entrevista - Carol e Andrea/Mediadoras).

Quando questionados se consideravam suficiente a formação recebida para atuar junto ao público infantil, novamente surgiu a compreensão de que o conhecimento acerca do trabalho a ser desenvolvido com as crianças é adquirido por meio da prática (até mesmo divergindo do que é aprendido na teoria). Os mediadores indicaram, ainda, um aspecto importante na formação: serem alertados sobre situações inusitadas que podem surgir e aprenderem como agir e a quais instâncias recorrer.

Andrea: A formação deu uma base, mas foi com a experiência mesmo que fomos aprendendo. E continuamos aprendendo, porque não tem como prever todas as situações e botar no curso de mediação, você não sabe o que esperar.

John: Eles forneceram muitas situações que poderíamos enfrentar, isso foi bom para nos preparar para o que pode acontecer e a quem recorrer. Eles passaram uma segurança para agirmos e acho que isso foi importante! (Entrevista - Andrea e John/Mediadores).

A falta de diálogo nos cursos de graduação (bacharelado e licenciaturas) sobre a educação fora dos espaços escolares e a não contemplação da infância (já que serão futuros professores apenas dos segmentos de ensino fundamental e médio) também foram aspectos pontuados.

Carol: Eu faço licenciatura em Educação Artística e suporte teórico não tem nenhum (...). A Psicologia da Educação é geral, Educação Brasileira é geral, Filosofia, Sociologia, Educação - tudo é geral! Nada tem um enfoque na Educação Infantil. A única preparação que tenho para a Educação Infantil é na hora do estágio obrigatório. Até aí [na disciplina obrigatória de estágio] eu só aprendo na prática mesmo. Tenho a teoria do estágio, mas não é voltada para Educação Infantil também.

John: Eu fiz história, na licenciatura, para público infantil também não tinha nada, porque eu só posso dar aula de 6ㅜ ao 9ㅜ ano [do Ensino Fundamental] e Ensino Médio. Na minha graduação atual [Conservação e Restauro], como é uma área bem técnica para lidar, como você vai falar de conservação e restauro com crianças? Isso não é abordado, de maneira nenhuma, temos que "nos virar nos 30" (Entrevista - Carol e John/Mediadores).

No Museu de Arte do Rio, desde sua abertura, há um programa específico de formação continuada da equipe. Entretanto, no ano de 2017, assim como o Museu Casa de Rui Barbosa e a Casa da Ciência, a Instituição sofreu cortes na 
verba, gerando redução da equipe e problemas para a estruturação do programa de formação interna.

Temos um Programa de Formação Continuada de equipe, é interno, com uma metodologia de Grupos de Trabalho [GTs] onde toda a equipe se divide entre quatro temas (1- narrativas fantásticas 2- acessibilidade, 3- imagens e palavras, 4- a cidade e o outro, que pensava a diferença e alteridade). A partir desses quatro temas, os mediadores olham para as exposições, estudam e pensam nas ações e práticas. Em maio [de 2017] nós tivermos uma reestruturação da equipe, que foi reduzida à metade por corte de verba e não pode ser mais dessa forma (...). Antes, nós tínhamos os encontros em todas as segundas-feiras, que nos era muito valioso. Em uma semana tínhamos uma formação nossa, só da Equipe de Referência (Educadores de Projetos e os Educadores Sêniores), para nos formarmos (formar formadores é importante!) e na semana seguinte era a formação com a equipe inteira junto. Essa formação com a equipe inteira era quinzenal. Agora, por uma questão de escala, não conseguimos mais reunir a equipe inteira na segunda-feira e os quatro GTS de estudos foram reduzidos à um - que é geral. Isso tem prejudicado muito nossa estrutura, obviamente! (Entrevista - Clarisse / Educadora de Projetos).

Atualmente, mesmo com o corte de verba e as escalas rígidas de trabalho, o Programa de Formação Continuada da equipe continua ocorrendo na Instituição com nova organização e método de trabalho. O entendimento de que há um "perfil mais adequado" de mediadores para atuar com diferentes tipos de público (como as crianças por exemplo), assim como na Casa da Ciência, foi um dos pontos revelados na fala da Educadora de Projetos. Foi possível perceber, novamente, a importância dada à formação dos mediadores a partir da troca de saberes com os pares - sujeitos mais experientes. A importância de uma equipe multidisciplinar, no sentido de compartilhar e agregar novos conhecimentos, também foi mencionada.

Nos momentos de formar os GTs, para a formação interna, tentamos pensar um pouco qual educador pode ser importante estar junto com outro educador, pelo perfil. Alguns educadores têm um perfil mais forte para trabalhar com crianças, outros com adolescentes e daí é bom trabalhem junto. Essa troca é muito importante para a formação, é uma forma também de os educadores se formarem - com a união formam um ao outro (Entrevista - Clarisse / Educadora de Projetos).

Assim como na Casa da Ciência, o Museu de Arte do Rio busca chamar especialistas para ministrar a formação dos mediadores. Todavia, os cortes no orçamento têm impossibilitado esse tipo de prática formativa na Instituição. Nesse aspecto, a Educadora de Projetos salienta a importância do vínculo empregatício (CLT) para que se diminua a rotatividade desses profissionais e, desta forma, possam alcançar uma memória de formação. No que é referente à formação para a recepção do público infantil, a entrevistada considera que o tema sempre esteve em pauta nos GTs de formação continuada da equipe. 
Em dezembro de 2017, o Museu de Arte do Rio dedicou o projeto "Partiu MAR"62 apenas à visitação do público de Educação Infantil da $\mathrm{SME}^{63}$. Na opinião da Educadora de Projetos, esse foi um momento em que toda a equipe precisou fazer uma formação mais especializada para atuar junto ao público infantil, uma vez que, mesmo os mediadores que não possuíam o "perfil mais adequado" para essa tarefa precisariam atuar com esse segmento.

Entretanto, na concepção dos mediadores, essa formação específica para receber o público de Educação Infantil não ocorreu de forma tão sistematizada ou que alcançasse a todos. Três mediadores da Instituição foram entrevistados, todos com 2 anos de trabalho no local. Quando questionados sobre a existência de uma formação específica para o trabalho junto ao público infantil, os entrevistados apresentaram divergência, tentando, entre eles, compreender se as práticas que possuíam seriam, efetivamente, processos formativos.

Enzo: Temos uma formação proposta pelos Educadores de Projetos (pelos superiores) e tem a formação que compartilhamos entre nós [entre os mediadores]. Temos muita formação interna pela troca com colegas mais experientes - como o Pedro, por exemplo, que é pedagogo. Ele tem um entendimento da criança, e das relações com as crianças, que muitos de nós ainda não temos.

Maximiliano: Isso é o entendemos como formação, mas algo como formar mesmo não temos. Dentro desse contexto do final do ano [período em que o museu recebeu apenas turmas de E.I], tivemos uma discussão maior sobre o público infantil.

Abel: Foi a partir de uma aula magna de um professor da UERJ, que se chama Aristeo, em que alguns educadores daqui foram como ouvintes. Esses mediadores voltaram com essa discussão para os GTs que eram específicos para falar de Educação Infantil.

Maximiliano: Claro que essa experiência passou por várias falhas. Têm mediadores que não sabem nem dizer exatamente o que aconteceu (...). Eles [mediadores] também tiveram pouquíssimo tempo para estar lá e a definição de quem iria [assistir a aula magna] foi algo meramente burocrático. É claro que estávamos todos mobilizados nessa discussão, mas não deu! (Entrevista - Enzo, Abel e Maximiliano/Mediadores).

Nesse diálogo entre os mediadores, várias percepções podem ser extraídas sobre a formação dos mediadores dentro da Instituição. Um fato a ser destacado é que, assim como na Casa da Ciência, consideram que existe dois modos de formação da equipe: (i) Programa de Formação Continuada - promovido pelos Educadores de Projetos que buscam apresentar leituras, discussões ou até mesmo parcerias com pesquisadores e universidades e (ii) a formação compartilhada entre pares - por colegas educadores mais experientes.

\footnotetext{
${ }^{62}$ Programa que conta com a disponibilização de ônibus para o transporte de estudantes da rede pública.

${ }^{63} \mathrm{~A}$ opção por receber exclusivamente as unidades de E.I no mês de dezembro se deu pois, nesse período, os outros segmentos de ensino já estavam com um contingente reduzido de alunos devido ao período escolar (recuperação, férias etc).
} 
Outro aspecto a ser observado é que, ao contrário da percepção da Educadora de Projetos do Museu, nenhum dos mediadores mencionou ou lembrou da "memória de formação" destacada pela entrevistada. Ou seja, o Programa de Formação Continuada (que contou com a participação de pesquisadores especialistas no tema) e as outras discussões e leituras promovidas não alcançaram esses mediadores, mesmo atuando há bastante tempo na Instituição. Nesse sentido, é importante retomar a fala da Educadora de Projetos sobre como o corte de verbas vem prejudicando a formação interna da equipe - a falta de recursos para promover cursos com pesquisadores/especialistas, a dificuldade para reunir a equipe em um momento de formação comum a todos, o cancelamento das temáticas específicas de estudo entre os educadores, são alguns dos obstáculos apontados pela educadora.

Pelo diálogo entre os entrevistados, entende-se que, no momento atual da Instituição, a formação entre os pares obtém maior êxito do que o programa institucional de formação continuada devido à falta de estrutura e organização. $A$ formação oficial que recebem no Museu é mais voltada para os estudos de mediação. Especificamente no que tange ao trabalho com o público infantil, consideram que se configura em um conhecimento adquirido a partir da própria prática e das experiências vividas e compartilhadas pelos colegas de profissão.

Quanto à qualidade das discussões promovidas sobre o público infantil pelo programa institucional de formação continuada da equipe, a insatisfação foi recorrente. Percebe-se que havia no Museu a vontade de promover um debate diferenciado sobre a infância entre os mediadores. Entretanto, pela falta de tempo e estrutura, a proposta não se efetivou.

Diferente dos mediadores da Casa de Rui e da Casa da Ciência, que em sua maioria eram graduandos contratados pelas instituições como estagiários, no MAR os mediadores eram profissionais formados, com vínculo empregatício (CLT). Em seus cursos de graduação, também não foram contempladas as temáticas sobre infância e educação fora dos espaços escolares. Assim como a mediadora Maria Luiza, do Museu Casa de Rui Barbosa, que por interesse buscava discutir sobre o público infantil em sua formação, os mediadores Enzo e Maximiliano também revelaram que, por interesse pessoal ou de algum professor, incluía-se na formação a discussão sobre a educação para além dos espaços escolares e sobre o público infantil. Já o mediador Abel, assim como a mediadora Carol da Casa da Ciência, relatou a experiência com crianças nas práticas das disciplinas de estágio obrigatório e o conhecimento adquirido sobre a recepção ao público infantil a partir da prática de trabalho em museu e centros culturais. 
Enzo: Eu tive [formação] meio que de forma indireta porque eu acabei pesquisando a infância para o meu TCC. Também, em todo local em que fiz estágio de graduação (e todos os locais em que trabalhei até hoje), foram relacionados a esses ambientes e espaços como museus, galerias etc.

Abel: Eu fiz estágio (um monte de estágios) de prática, onde você tem que assistir e ficar na escola lidando diretamente com criança - aquilo que você vivencia mesmo. Nos espaços não formais foi quando eu trabalhei, que tive a experiência.

Maximiliano: Eu tive uma disciplina chamada "Pesquisa e Prática de Ensino", que era da Faculdade de Educação, em que por causa do puro interesse do professor, tivemos a experiência de investigação em educação no contexto não formal, mas não pensando na especificidade do público, muito menos Educação Infantil. E pensando em como o currículo de graduação em História é formado, porque história só faz parte do currículo a partir de determinada série em diante, não tive qualquer disciplina que dialogasse com Educação Infantil (Entrevista - Enzo, Abel e Maximiliano/Mediadores).

Analisando as respostas obtidas nas três instituições, pode-se perceber que na Casa da Ciência e no Museu de Arte do Rio existem programas específicos de formação interna da equipe que se preocupam em incluir as especificidades do público infantil nessa formação. Na Casa da Ciência, segundo o entendimento dos mediadores, o foco no público infantil está atrelado a uma preocupação sobre como irão "passar as informações da exposição" para as crianças pequenas, "que ainda não possuem um entendimento mais elevado da realidade" e necessitam que os mediadores utilizem um vocabulário mais específico (adequação da linguagem). Já no Museu de Arte do Rio, para a Coordenação das ações educativas, a formação para a recepção do público infantil sempre esteve na pauta dos grupos de estudo e palestras (embora os mediadores discordem ou não lembrem dessa ênfase dada ao público infantil ao longo dos programas de formação oferecidos pela instituição). De toda forma, um movimento do Museu em receber apenas o público escolar de E.I no final do ano de 2017 fez surgir a demanda de formação específica de toda a equipe - mesmo para os mediadores que não possuíam o "perfil mais adequado" para o trabalho de recepção a esse público.

Carvalho (2016) ressalta que na divisão estabelecida entre os educadores para o trabalho a ser realizado com diferentes públicos, há sempre a figura do mediador "que tem mais jeito com crianças" e assume, com maior frequência, a recepção aos grupos com crianças pequenas. Considera que esses sujeitos, de fato, conseguem estabelecer uma relação mais próxima com as crianças - lançam perguntas, aproveitam as falas da interlocução, buscam estabelecer uma conexão entre o conteúdo das exposições e possíveis experiências das crianças. Contudo, mesmo esses mediadores com "perfil mais adequado" sentem o cansaço e o desgaste em relação ao trabalho oferecido, ficam sobrecarregados. 
Marandino (2008) coaduna com a perspectiva ao afirmar que, quando se discute sobre a atuação dos mediadores em museus, "é comum ouvirmos falar que um profissional tem o dom para fazer algo, ou até mesmo que faz algo tão bem que nasceu para aquilo" (MARANDINO, 2008, p.28). Esse entendimento induz a pensar que determinada habilidade é uma característica inata e que, portanto, não pode ser aprendida, muito menos ensinada. Ressalta que essa avaliação da "habilidade inata / dom", se levada ao extremo, torna inviável a melhoria dos serviços de mediação nos museus. Seria preciso procurar todas as pessoas com tais habilidades e, quando não encontradas em número suficiente, os setores educativos teriam que trabalhar com profissionais não qualificados.

No entanto, considera que é possível entender o trabalho do mediador de outra forma - como algo que pode ser aprendido. No trabalho de mediação há diversos aspectos que podem ser estudados e planejados, como o percurso pelo museu, os temas relevantes, as questões a serem colocadas em determinados locais do trajeto, o tempo da visita, dentre tantos outros. Entretanto, salienta que há também os elementos surpresas dessa prática que - mesmo a equipe educativa sendo qualificada para o trabalho - não há como prever. Nesse momento, se confunde o "dom" com a formação. Para a autora, o mediador de museus convive com imprevisibilidades da prática e deve lidar com elas de forma inteligente através do exercício da sistematização de problemas, da implementação e da improvisação. Esse aspecto da formação na prática, a autora denomina "reflexãona-ação".

Examinando os depoimentos das coordenadoras e dos mediadores entrevistados, foi possível detectar que a formação dos mediadores para trabalhar com o público infantil ocorre de duas maneiras distintas (mesmo no Museu Casa de Rui Barbosa que afirmou não desenvolver formação específica): cursos e programas institucionais de formação continuada e formação compartilhada entre pares / colegas mais experientes. A formação pelos cursos e programas institucionais consiste, geralmente, em ações desenvolvidas pelos coordenadores responsáveis pelas atividades educativas do museu. Buscam apresentar leituras, discussões ou até mesmo parcerias com pesquisadores/especialistas sobre estudos de mediação e de público. Já a formação compartilhada entre pares/ por colegas educadores mais experientes é constituída na própria prática da recepção ao público infantil. A partir da troca de experiências e observações com outros profissionais que desenvolvem a função, os mediadores vão construindo os alicerces de sua própria prática educativa, selecionando o que aderir ou excluir. Por vezes, a compreensão de que o conhecimento acerca do trabalho a ser 
desenvolvido com as crianças é adquirido por meio da prática prevalece sobre o que é aprendido nos cursos e formações institucionais. Fato que acontece, sobretudo, devido a algumas divergências da teoria que são encontradas na prática com as crianças e pelas dificuldades financeiras e burocráticas de alcançar toda a equipe nos cursos de formação.

Os estudos de Marandino (2008) coadunam com a perspectiva dual de formação percebida na fala dos entrevistados. Para a autora, diante dos inúmeros imprevistos e surpresas que se dão no encontro diário da ação de mediar, duas ações podem ser cabíveis no que tange à formação para atuar de maneira de solucionar o conflito, reelaborando a maneira de agir: reflexão-na-ação e reflexão sobre a reflexão-na-ação. Com relação ao primeiro tipo de formação, esclarece que, durante a ação, o mediador passa por diferentes situações-problema (conflitos, dúvidas, desinteresse do visitante/grupo etc.) e, para buscar a solução, reflete sobre as experiências adquiridas e, na própria ação, toma uma decisão. Essa tomada de decisão se constitui um processo de formação, mesmo que para o mediador suas decisões sobre o agir não sejam tão claras ou conscientes. A autora destaca que a reflexão-na-ação também pressupõe uma predisposição por parte do mediador para experimentar. Ao observar e analisar a sua própria prática e a de outros profissionais que atuam com ele, o mediador cria um repertório de práticas que funcionam e que não funcionam. Nesse sentido, cabe resgatar as perspectivas teóricas de Benjamin (2012) e Vigotski (2009), que enfatizam a troca de experiências com os sujeitos mais experientes, pois "o conselho tecido na substância da vida vivida tem um nome: sabedoria" (BENJAMIN, 2012, p.76).

A outra formação - "reflexão sobre a reflexão-na-ação" - ocorre por meios variados como as avaliações contínuas da equipe, reuniões de grupo, ações de capacitação dos mediadores, participação em congressos, grupos de pesquisa e discussão, realização de cursos, dentre outros. Estes momentos promovem o olhar crítico sobre a ação e auxiliam, por meio da troca de experiência, a tarefa autoavaliativa da própria ação, da equipe e até mesmo dos objetivos propostos pela instituição. Esse processo formativo é fundamental para a melhoria das ações futuras.

A autonomia na criação da própria prática educativa dos mediadores a partir de um processo de apropriação e ressignificação dos aprendizados adquiridos em meio a esses dois tipos de formação (institucional e prática entre pares/sujeitos mais experientes), foi outro aspecto recorrente nos depoimentos dos entrevistados, principalmente nas entrevistas da chefe da Seção de Educação da Casa da Ciência e da mediadora do Museu Casa de Rui Barbosa. 
Nesse sentido, Carvalho (2016) orienta que a heterogeneidade das ações desenvolvidas por cada membro da equipe de um setor educativo pode ser fator positivo. Entretanto, essa heterogeneidade, aliada à ausência de um planejamento global que oriente os sentidos educacionais das ações desenvolvidas pelo museu, pode levar não a autonomia, mas à individualização do trabalho realizado pelos mediadores - onde cada um atua da forma que sabe ou que considera mais correto, desenvolvendo o trabalho educativo de forma intuitiva. A autora preconiza então a importância de um plano educacional para instituições de memória, voltado a explicitar as regras e os sentidos da educação em instituições como museus e centros culturais. É preciso eleger o que é prioritário e apontar as atividades a serem desenvolvidas em um determinado período, de forma a oferecer a todos os seus profissionais um embasamento teórico que justifique o trabalho proposto.

Nas entrevistas com os profissionais que elaboram e que desenvolvem as ações educativas com as crianças, também foi possível elencar alguns aspectos considerados importantes para uma formação mais completa: maior tempo destinado à formação (mesmo que seja apenas a observação antes de começar a receber os grupos de E.I); que os cursos e programas institucionais alertem sobre situações inusitadas que podem surgir, a formas de agir e a quais instâncias recorrer; a frequência nas discussões e estudos - que não ocorram apenas de modo emergencial, possibilitando a aquisição e troca de conhecimento a partir da participação em eventos, com profissionais de outras instituições culturais e com pesquisadores/especialistas.

Sobre as possibilidades de desenvolvimento de uma formação interna de qualidade para a equipe, um obstáculo apontado pelas três instituições investigadas foi o corte de verbas na área da cultura. Como resultado, a formação é inviabilizada pela redução da equipe, seja pela falta de concurso ou pela demissão em massa, gerando uma sobrecarga de trabalho que impede a participação em eventos, reuniões e cursos de atualização com a participação de pesquisadores/especialistas.

Outro fator detectado foi a falta de diálogo sobre a educação fora dos espaços escolares e a não contemplação da infância nos cursos de graduação (bacharelado e licenciaturas). Os mediadores afirmaram não possuir disciplinas que abordassem a temática da infância/Educação Infantil, pois seriam futuros professores apenas dos segmentos de ensino fundamental e médio. A única disciplina em que havia a prática educativa com crianças (mencionada por dois mediadores) foi o estágio obrigatório, mesmo assim, não eram contempladas 
discussões teóricas, e a aprendizagem também se dava apenas com a prática. Desta forma, tanto os estudos sobre a infância como os estudos sobre práticas de educação além dos espaços escolares, não permeiam as grades curriculares das diferentes áreas de formação - ficam a cargo do interesse do graduando ou de algum professor. 


\section{Crianças, exposições, professores e mediadores}

4.1.

A relação estabelecida pelos museus com o público infantil

Após a apresentação acerca dos museus investigados (missão, equipe educativa, estrutura, espaços expositivos, programas, metodologias e formação de mediadores), foi necessário pesquisar os aspectos interativos da relação museu/crianças que norteavam as práticas educativas com o público de E.I. nesses espaços.

Alguns estudos que se dedicam a analisar a relação entre museus e crianças apontam que o sujeito mais experiente - aquele que compartilha da visita com a criança (mediador, professor, família) - deve ser interessado e curioso pelas temáticas que os museus abordam, transmitir prazer e pulsão naquilo que contempla junto à criança. O principal aspecto da experiência estética que pode ser possibilitada nesses espaços é a construção de significados pelo sujeitocontemplador (crianças e adultos) (LEITE, 2005; MOURA, 2011; FALLON e CHAVEPEYER, 2013).

Nesse sentido, Moura (2011) aponta a necessidade de que haja nos espaços museais profissionais sensíveis e preparados com quem as crianças possam compartilhar, refletir e ampliar tempo e qualidade da experiência vivida. Destaca como aspecto importante do trabalho de mediação com crianças a possibilidade de construção de narrativas que venham a interagir com outras narrativas, orientadoras ou questionadoras, transformando a experiência individual numa experiência coletiva (entre mediadores, pares, famílias, professores). A autora compreende que, alcançando uma dimensão social e histórica, a mediação com crianças nos museus pode diminuir o risco anunciado por Benjamin (2017), que advertiu sobre o empobrecimento da experiência pela perda da capacidade de narrar.

Martins, Picosque e Guerra (2011) concordam que a mediação é uma tarefa que, quando desenvolvida de forma criadora, pode ampliar a potencialidade de atribuição de sentidos por um sujeito fruidor que se torna mais sensível. Para tanto, a mediação precisa ser pensada como uma ação específica. Para as autoras, mediar implica perceber a presença do sujeito como um todo. Isso significa não apenas provocar seu olhar cognitivo, mas também promover um 
contato que deixe canais abertos para os sentidos, sensações e sentimentos despertados para a imaginação e a percepção.

Entretanto, analisando trabalhos de investigação sobre o público infantil em museus, alguns apontamentos sobre a atuação inadequada na recepção às crianças são sinalizados. Geralmente, essa inadequação se refere ao fato de os profissionais dos museus adultizarem as crianças, ou usar um vocabulário infantilizado, ignorar suas falas e, principalmente, desconsiderar aspectos importantes na forma como a criança se apropria do mundo como a interatividade, a ludicidade e a possibilidade de fantasia e imaginação. Para além desses fatores, outro conflito constantemente encontrado é que o comportamento social próprio da criança, geralmente, difere do esperado ao se frequentar os espaços museológicos, A expectativa é a da não ação - prestar atenção, escutar os mediadores, aguardar o momento correto para falar, permanecer com os braços para trás ou de mãos dadas com outra criança. Esse comportamento desejado contraria os modos da criança apreender e se apropriar da cultura, de imaginar e de estabelecer conexões (GABRE, 2016; POL e ASENSIO, 2006; CARVALHO, 2013; CARVALHO e LOPES, 2016; OLIVEIRA, 2011; LEITE, 2005; 2011).

Com base nos apontamentos da literatura e em diálogo com a análise das entrevistas e da observação de campo, busquei compreender: Os museus percebem a potencialidade de seus espaços para as crianças? Os mediadores compartilham dessa visão? A prática educativa com o público escolar de Educação Infantil é alinhada ao discurso que se apresenta sobre público infantil nas instituições?

\subsubsection{O que os educadores dos museus falam sobre as crianças}

Procurando responder essas questões, apresento as constatações sobre o público infantil que os educadores dos museus investigados expressaram nas entrevistas: se e como consideram a capacidade das crianças se apropriarem do conteúdo das exposições, os benefícios que julgam que a experiência no museu pode trazer e os aspectos que consideram importantes no trabalho junto a esse público.

No que se refere às "percepções sobre a relação que as crianças estabelecem com o conteúdo das exposições", os mediadores das três instituições investigadas, de tipologias e temáticas distintas, afirmaram compreender que esse público é capaz de estabelecer relações com as temáticas abordadas nos museus. Destacaram a autoria das crianças em criar e estabelecer suas próprias conexões e comparações entre conhecimentos prévios e os conteúdos abordados 
nas exposições. Relataram, também, o desejo sempre presente entre as crianças de acrescentar suas experiências à mediação:

Carol: Eles mesmos já trazem para a realidade deles porque eu acho que é mais fácil para eles entenderem. Eles sempre querem acrescentar alguma coisa [na mediação] - é sempre assim! (Entrevista - Carol / Mediadora da Casa da Ciência)

Os sinais de interesse são muitos - a partir da pergunta e também do fato de criar comparações entre tudo que ela [criança] está vendo com a vida dela. Por exemplo, quando falam "A minha tia tem um desse. A minha família tem um não sei o quê..." E ela [criança] vai começando a criar sua rede de comparação (...). Têm coisas que, às vezes, somos até pegos de surpresa com as informações que são trazidas por essas crianças. (Entrevista - Enzo/Mediador do Museu de Arte do Rio)

Na Casa da Ciência e no MAR, os mediadores consideram que, muitas vezes, o público infantil demonstra maior recepção ao tema do que os demais visitantes. Reconhecem momentos em que as crianças conseguem articular seus conhecimentos de forma a "tomar" o lugar de mediação.

Em um grupo que recebi tinha uma criança que deu aula para o resto das crianças [da turma]. Fomos discutir "Dja Guata Porã" (...) e ele começou a falar "Não tem mais índios porque os brancos chegaram.". Ele foi bem sucinto também! Daí eu pedi "me fala mais?" e ele começou a contar "os brancos entraram em guerra e mataram os índios" de maneira didática e simples (Entrevista - Abel/Mediador do Museu de Arte do Rio).

Tem uma [criança] que acho que toda vez que ela vai ao parquinho aqui ao lado ela tem que vir na Casa da Ciência trazer a mãe, a avó, trazer alguém. Aí eu falei "Nossa! Ela deve gostar muito!" porque não mudou a exposição e ela veio 3 vezes na mesma exposição. Ela, às vezes, ficava mediando - ela toma até o nosso lugar! (Entrevista - Andrea/Mediadora da Casa da Ciência).

Leite (2011) sinaliza que essa capacidade da criança de estabelecer conexões sobre suas experiências e o conteúdo dos museus, em que estão propensas até mesmo a "tomar o lugar da mediação", advém do fato de a criança ser sujeito histórico, social e cultural. Na busca pela inteligibilidade dos objetos, a criança coloca em jogo seus referenciais, todo o seu conteúdo de significações para construir a interpretação e a decodificação do que vê.

Esse processo de construção de conhecimento a partir da interação com o acervo e com os mediadores, também foi destacado pelos educadores dos museus investigados como uma qualidade especial das experiências a serem vividas nos espaços expositivos para que as crianças estabelecessem relações com as temáticas abordadas. Consideram que essa especificidade dos museus e centros culturais contribui para uma melhor compreensão de determinados temas.

É muito mais fácil, às vezes, você aprender no espaço expositivo e interativo do que em uma sala de aula. A experiência vivida é muito significativa. (...) Ter alguém falando sobre aquilo para você, acho que atinge a criança de outra forma. (...). Acho que isso é interessante para criança, tornar e fazer o conteúdo ficar mais concreto (Entrevista - Paula/Chefe da Seção de Educação da Casa da Ciência). 
Os mediadores do MAR salientaram ainda o potencial das crianças para alcançar uma dimensão estética na forma de adquirir conhecimentos e se relacionar com as temáticas do museu. Consideram que conhecer o conteúdo das exposições por meio tátil, empírico e sensorial é uma característica desse público.

Maximiliano: Lembro bem da exposição da Rivane Neuenschwander ${ }^{64}$ (...) que falava sobre medos infantis e várias crianças se sentiram com medo lá dentro - o que é isso, senão ser afetado pela exposição e pelo conteúdo da exposição? Elas ainda nem sabiam ler.

Enzo: A criança pode não ter, necessariamente, esse entendimento do conteúdo da exposição em sua forma formal, mas pode ter até em seu próprio corpo.

Abel: É uma coisa estética e empírica, porque ela tem que estar ali, tem que estar sentindo a exposição (...), sentindo o conteúdo (Entrevista - Enzo, Abel e Maximiliano/Mediadores do Museu de Arte do Rio).

Sobre a perspectiva de aquisição de conhecimento na infância, a partir da experimentação sensorial para se apropriar do mundo, Dewey (2010) aponta que a distinção entre elementos racionais e sensoriais é sempre intermediária e transitória. No processo de construção do conhecimento, as concepções se transformam em significados intrínsecos do material da experiência mediado pelos sentidos. Ressalta que "até as concepções cientificas têm de ser encarnadas na percepção sensorial para serem aceitas como algo além das ideias" (DEWEY, 2010, p. 449-450). Camargo (2011) concorda com essa perspectiva e considera que se o conhecimento racional visa uma adequação da mente ao mundo real, deve prevalecer uma associação com o conhecimento estético, porque "ser afetado pela confusão e obscuridade do real oferece-nos uma aproximação mais eficiente da realidade, em comparação com a "clareza" minimalista de um conceito sobre o mundo" (CAMARGO, 2011, p. 13).

A importância dessa interação com o mundo e com outros sujeitos na forma de as crianças se apropriarem do conteúdo das exposições é percebida pelos mediadores. Reconhecendo as individualidades e singularidades presentes nas crianças de cada grupo, conseguem distinguir algumas formas de a criança se relacionar com as temáticas abordadas a partir do diálogo estabelecido e por meio da demonstração do arrebatamento diante do que é visto, vontade de registro, afetividade com os mediadores e a troca com os pares.

Toda vez que fazemos a mediação, seguimos uma história, então tem como perceber se a criança está vindo nessa história (...). Você vai pegando o retorno das crianças conforme a exposição vai passando (Entrevista -Andrea/ Mediadora da Casa da Ciência).

Enzo: Existem várias crianças e cada criança vai mostrar isso de uma forma - tem criança que vai estar o tempo inteiro te perguntando sobre as coisas (...) Eu já recebi

64 Exposição "O nome do medo" que se propôs a investigar o medo a partir do olhar das crianças, que foram estimuladas a listar e desenhar seus maiores temores e a construir capas com materiais ricos em texturas e cores. Os artigos desenhados foram transformados em capas estilizadas, criadas pela artista com a colaboração de um fashion designer. 
grupos em que a criança não falava nada, mas eu via no olho da criança que ela estava doida de felicidade porque estava tocando nas coisas.

Abel: Talvez, um sinal também seja o ineditismo. Quando eles falam "caramba, nunca vi isso!". A vontade do registro também, tem criança que já entra com celular e "pápápápápá".

Maximiliano: Também acho que um grande indicativo é a aproximação afetiva: o chegar próximo, sentar perto de você, segurar sua mão, te dar um abraço do nada. Isso mostra um pouquinho como é a relação que estamos construindo (Entrevista Enzo, Abel, Maximiliano/Mediadores do Museu de Arte do Rio).

Percebendo algumas características dos grupos de Educação Infantil que visitam a instituição, a mediadora do Museu Casa de Rui Barbosa consegue identificar pistas para perceber o envolvimento das crianças com o espaço e seu acervo de acordo com a faixa etária. Com as crianças menores ( 0 a 3 anos) detecta que, no momento em que passam a perder o receio do ambiente e começam a ficar mais agitados com tudo o que veem, é um sinal de que a experiência está sendo interessante. Já com as crianças entre 4 e 6 anos, considera que quando conseguem se acalmar e se concentrar com os detalhes da Casa, começam a estabelecer relações mais profundas. Também destaca como um bom feedback quando as crianças começam a falar coisas que não tem nada a ver com o que ela está falando, mas que estão relacionadas com a Casa, pois uma cadeira, um quadro ou um livro podem ter chamado mais atenção, e declara: "eu não vou brigar porque eles não estão me ouvindo".

No MAR e na Casa da Ciência, foi possível constatar que, por vezes, o protagonismo estava no que era "ensinado/transmitido" pelos mediadores mais do que na capacidade de as crianças estabelecerem suas próprias conexões e relações. Algumas falas dos mediadores levam à interpretação de que não são as crianças que fazem a relação com a realidade vivida em meio à cultura na qual estão inseridas, são os mediadores que proporcionam esse ato reflexivo.

Nós vamos trocando ideia na grande maioria das visitas, ainda que as crianças não tomem iniciativa de falar sobre as temáticas. A nossa prática tenta ensinar aquilo de alguma maneira (Entrevista - Abel/Mediador do Museu de Arte do Rio).

$\mathrm{Na}$ exposição do Aedes Aegypti, com toda escola fazíamos uma conversa após a exposição para ver o que eles tinham aprendido e as crianças tinham assimilado, praticamente, tudo o que tínhamos falado (Entrevista - Carol/Mediadora da Casa da Ciência).

Sobre os "benefícios que a experiência no museu pode trazer para o público de E.I", foi possível perceber que consideravam que o maior benefício desse tipo de experiência é a possibilidade de estar em contato com um espaço diferenciado que possibilita outras formas de se apropriar dos conhecimentos produzidos pela humanidade. Em meio ao discurso expositivo, que apresenta os conhecimentos/as coisas do mundo em uma outra organização estética - diferente 
da que se encontra comumente no cotidiano - são estimuladas a fruição e a construção de aprendizado. Trazer conteúdos diversificados expostos de formas interativas, viabiliza uma outra forma de estar no mundo, diferente do modo operacional e massificado que o ritmo da vida atual impõe. Na concepção dos entrevistados, aprender a se encantar, despertar um olhar sensível - para além do que está dito - traz para as crianças o conhecimento sobre outras formas de se expressar, de falar, de pensar e de agir.

Não que a criança tenha que visitar só museu, mas que ela saiba também que o museu é um espaço de fruição e de aprendizado em diferentes níveis (...). Acho que isso é um pouco da função do museu: criar essa forma de estar no mundo, não é só pela forma operacional (...). Aprender a se apropriar dos lugares, aprender a se encantar, aprender a olhar além do que está dito ali (Entrevista - Francisca / Museóloga do Museu Casa de Rui Barbosa).

Os entrevistados dos três museus investigados também consideram que um dos benefícios de fazer com que as crianças frequentem, desde cedo, os museus e centros culturais é aprenderem a se apropriar desses locais. Compreendem a criança enquanto consumidora e produtora de cultura e, portanto, possuidora do direito de ocupar esses lugares. Avaliam que ter acesso aos espaços de cultura, compreender que são espaços de poder, contribui para a formação humana e cidadã.

Quando você traz as crianças para cá, você está atuando diretamente na democratização dos espaços - desde pequenos - porque as pessoas vão ter acesso a esses lugares de cultura, que muitas vezes também são lugares de poder, que excluem. No momento em que você tem as crianças aqui, desde cedo, elas estão ocupando esse lugar para entender também como elas são produtoras de cultura todos são - e como elas também podem ocupar esses lugares como criadores (Entrevista - Clarisse / Educadora de Projetos do Museu de Arte do Rio).

Essa percepção dos entrevistados, que relacionam o benefício do acesso à cultura com a formação de um cidadão crítico, alinha-se à concepção de Kramer (1998), que reitera a natureza política das instituições culturais na construção do exercício da cidadania. No diálogo entre educação e cultura, a autora enfatiza a cidadania como a necessidade de forjar a consciência de que todos têm direito à educação e à cultura - de tomar posse do saber científico, artístico e cultural e, com ele, produzir e criar.

Os mediadores do MAR, especificamente, encaram que visitar museus desde a infância é um "benefício a longo prazo". Consideram que a visita pode mostrar às crianças que o mundo tem inúmeras possibilidades, não é só aquilo que se vê, se aprende ou se acostuma no cotidiano. Para os mediadores, ainda que tenhamos uma educação que nos deixe conformados com uma série de escolhas, o museu pode mostrar que o mundo é mais do que aquilo que parece 
naturalizado. Contudo, compreendem que alguns aprendizados surtirão efeito apenas no futuro, deixando de enxergar a criança como sujeito já no presente.

Enzo: Preparamos, de certa forma, o campo para algumas diversidades. Por exemplo, quando vou contar uma história que é de lemanjá - só que não coloco nem o nome dela - de certa forma eu já estou fazendo isso, preparando esse campo para que, futuramente, essa criança, quando ela se tornar um adolescente, não venha aqui e vá dizer "Ah, isso aqui é só macumba". Mesmo sabendo que existe essa possibilidade, que isso pode até ocorrer, mas acho que entra como benefício a longo prazo (Entrevista - Enzo /Mediador do Museu de Arte do Rio).

Sobre essa concepção que valoriza os saberes da criança apenas no futuro desconsiderando seu presente, Moura (2011) e Kramer (2000) alertam que, com a compreensão atual acerca da criança como um ator social e a infância como uma construção social, não cabe mais enxergar/tratar as crianças como um vir a ser. É preciso que sejam reconhecidas enquanto componente constante e estrutural da cultura e da sociedade no presente, que interagem e modificam o meio onde vivem.

A qualidade das interações com outros sujeitos (no caso, os mediadores) também foi destacada como um fator positivo para as crianças em seu processo de aquisição de novos conhecimentos.

Eu acho que reforça um pouco algumas coisas que a criança aprende em outros lugares - não só na escola, mas em casa também. $E$ isso é bom ver isso com outras pessoas falando, de outras formas (Entrevista - Maria Luiza / Mediadora do Museu Casa de Rui Barbosa).

A perspectiva apontada pelos mediadores coaduna com a teoria de Vigotski (2009), que dá especial importância às interações sociais entre os sujeitos para a formação humana. Nesse aspecto, pode-se compreender a função do mediador e do professor como os sujeitos mais experientes, responsáveis potenciais pela experiência educativa que se deseja oferecer às crianças. Moura (2011) destaca como igualmente importante as interações das crianças com outras crianças, incentivadas pelos mediadores e professores, para o processo de aprendizagem e formação pretendidos.

Ressaltando o fato de a população brasileira ainda não possuir o hábito de frequentar museus e espaços culturais, os educadores do Museu Casa de Rui Barbosa e da Casa da Ciência indicaram que, a partir de um trabalho de mediação prazeroso e atraente para as crianças, esse público pode retornar à instituição trazendo seus familiares. Desta forma, pode-se compreender que nas instituições supracitadas a criança é percebida como um possível agente estimulador das atividades culturais da família.

Uma criança, dentro de uma casa, pode levar outras pessoas a irem ao museu e acho isso importante porque no Brasil não temos muito uma cultura de ir em museus (Entrevista Maria Luiza/ Mediadora do Museu Casa de Rui Barbosa). 
Carol: Essa experiência pode fazer com que ela queira frequentar museus ou não mais tarde.

Andrea: Se ficamos chamando a atenção da criança, ela vai pensar que no museu sempre tem aquela pessoa que "não deixa nem eu falar". Quando você conversa, entra na viagem, deixa ela livre, eu acho que ela volta e ainda traz outras pessoas (Entrevista - Carol e Andrea/Mediadores da Casa da Ciência).

Também refletindo sobre os benefícios que os museus e centros culturais podem trazer para o público infantil, em um movimento reverso, a educadora de projetos do Museu de Arte do Rio e a museóloga do Museu Casa de Rui Barbosa destacaram o quanto a presença das crianças também pode ser profícua para os museus. Para as entrevistadas, as atividades com esse público infantil no espaço expositivo contribuem para provocar a abertura de possibilidades e a transformação de como o próprio museu e a população enxergam os espaços museológicos. Tornando-o mais vivo, mais barulhento e democrático para diferentes públicos, a presença das crianças pode ajudar a romper com o entendimento de um espaço sacralizado de observação e silêncio.

É importante as crianças virem para o museu e provocaram aberturas, elas transformam muito o museu! (...) Desde 2013 [abertura do museu] ouvíamos muitos "shiu", por exemplo, até mesmo de outros visitantes quando fazíamos as visitas como as crianças. Agora temos ouvido poucos "shiu" ao longo dos anos (...). Acho que isso é porque as crianças vieram para o museu e também ajudaram a formar esse outro museu e formar outros públicos de museu. Quem visita o MAR, que não é criança, vai entender que também somos um museu de crianças que vão correr, que vão falar, que é barulhento (Entrevista - Clarisse / Educadora de Projetos do Museu de Arte do Rio).

Quando questionados sobre os "aspectos considerados importantes no trabalho junto ao público de Educação Infantil", de modo geral, os entrevistados destacaram o cuidado no uso da linguagem e na escolha dos temas abordados (o que realmente era importante conversar com aquele público nas exposições) para que a criança pudesse estabelecer relações e adquirir conhecimento.

É importante lidar pensando a realidade da criança. Mesmo que a missão seja falar sobre o Rui Barbosa - a pessoa dele dentro dessa casa e sua história - para uma criança de até 6 anos isso não é tão relevante (...). Buscamos relacionar a Casa em si mesma - a diferença da casa para hoje, a questão dos livros e da leitura e, aí sim, usar a imagem do Rui Barbosa. Falamos que ele era uma pessoa muito inteligente etc., mas não falamos que Rui Barbosa foi ministro porque a criança não vai conseguir linkar (...). Você não vai falar coisas novas só, mas que ela consiga relacionar com a realidade dela e consiga pensar dentro da Casa, e não só ficar escutando (Entrevista - Maria Luiza / Mediadora do Museu Casa de Rui Barbosa).

Carol: Tem que prestar atenção na criança - porque com a criança tem todo um outro jeito de mediar, porque ela tem a imaginação dela, a criatividade, a atenção, porque ela quer ver tudo ao mesmo tempo e essa curiosidade - de querer sair correndo para ver tudo. Aí temos que ficar atentos!

John: Tentamos dialogar com eles, criar histórias que eles façam parte, criar um meio através do diálogo para que eles se sintam atraídos pela obra ou parte, ou criarem uma história e, às vezes, é bem fantasioso e entrar nesse jogo deles. Isso é o que eu acho bacana, para eles se sentirem parte da exposição (Entrevista Carol e John/Mediadores da Casa da Ciência). 
Busco essa ideia de exploração de um lugar desconhecido, a ocupação. Procuro apelar para aquilo que eles veem, para coisas que eles reconheçam com certa facilidade e daí vou jogando pílulas de reflexão (Entrevista - Abel/Mediador do Museu de Arte do Rio).

Analisando o aspecto de criação de trabalhos específicos para o público infantil em museus (diminuição do percurso, adaptação da linguagem etc.), Fallon e Chavepeyer (2013) alertam que criança pequena não é sinônimo de obra pequena ou de um trabalho menos elaborado. Consideram que, por menor que seja, toda pessoa é sensível ao contato com o objeto artístico em uma experiência estética. Além de acreditar e confiar na capacidade e competência das crianças, é fundamental o respeito ao seu ritmo de descobertas e a confiança em seu modo singular de apreciar o que vê, sente e experimenta. No encontro com o museu, há um mundo de possibilidades e descobertas, portanto, "não é necessário sobrecarregar a criança com informações e emoções com as quais, devido à sua falta de maturidade psíquica, ela não pode fazer nada mais do que dar as costas ou ficar atordoada" (FALLON e CHAVEPEYER, 2013, p. 9, tradução da autora).

Uma preocupação salientada pelos mediadores do Museu de Arte do Rio e do Museu Casa de Rui Barbosa - de mostrar para as crianças que o museu pode ser lugar de diversão e de quebra de barreiras e regras sobre as formas corretas de se portar com o corpo naquele lugar - também evidenciou que os mediadores reconheciam que as crianças possuem formas diferenciadas de se relacionar com o espaço e que, muitas vezes, essas especificidades eram tolhidas pelos professores e pelos próprios espaços museológicos. No Museu de Arte do Rio, especialmente, os mediadores demonstraram reconhecer a especificidade da infância em relação ao corpo e ao lúdico como forma de sentir, se apropriar e conhecer aquele lugar.

Quando pegamos uma criança muito pequenininha temos a obrigação de fazer aquela experiência boa para tentar criar um vínculo afetivo. Tento deixar mais dinâmico, como muitas vezes não vemos a arte nos museus - porque não pode tocar, não pode falar e eu procuro deixar a criança livre (...). Gosto muito de perguntar e de ver as respostas deles. Também gosto de deitar com eles no chão da sala de música porque o teto é bem decorado e abre um pouco o entendimento de que no museu não pode fazer nada (Entrevista - Maria Luiza/Mediadora do Museu Casa de Rui Barbosa).

Quando recebo um grupo de Educação Infantil, eu trabalho muito com a escuta e com o corpo. Acho que o corpo - a linguagem corporal - é uma linguagem entendida desde muito cedo pela criança e tento fazer essa ligação entre o que o corpo trás e como aprender através desse corpo, do movimento, desse ambiente que nos rodeia. Quando falo do ambiente que nos rodeia, não falo só da cidade, estou falando também da natureza, do próprio ambiente, das relações criadas com os amigos e também comigo (Entrevista - Enzo /Mediador do Museu de Arte do Rio). 
Analisando o caráter educativo da experiência, Dewey (1979) considera a agitação das crianças um indicativo melhor do que a exibição de uma perfeita norma de comportamento exterior acompanhada de falta de interesse intelectual e emocional pelo que se está aprendendo. Alerta que o erro mais comum ao interpretar a liberdade de movimento (ou o lado físico e exterior da atividade) é separá-lo do seu lado interno - da liberdade de pensar, desejar e decidir. Esclarece que a liberdade de ação é sempre um meio para a liberdade de julgamento e para a capacidade de colocar em execução os propósitos tomados pelo indivíduo.

O autor ressalta as vantagens advindas do aumento da liberdade física ou exterior, pois considera que, sem em esta liberdade, é praticamente impossível conhecer o sujeito com quem se convive. Silêncio, imobilidade e obediência forçados impedem a criança de se revelar e criam uma uniformidade artificial. Considera que não pode haver completa quietude onde se deseja aprender. fato de erigir na escola ou no museu, o tradicional silêncio, indica um caráter não social.

Dewey (1979) salienta, também, que varia, em cada indivíduo, a quantidade de liberdade física necessária, tendendo, naturalmente, a decrescer com a idade. Adverte que sua completa ausência impede, mesmo no sujeito mais maduro, de ter contatos indispensáveis ao exercício normal de sua inteligência. Desta forma, defende que os impulsos e desejos naturais sejam encarados como o ponto de partida para a construção de conhecimento. Todavia, adverte que não há crescimento intelectual sem a tarefa de reconstrução - sem que esses desejos e impulsos sejam revistos e refeitos, por meio do trabalho de reflexão e reelaboração do próprio indivíduo. A capacidade de pensar é, para o autor, conectar a primeira manifestação de ação - o impulso - a outras tendências possíveis de ação, por meio dos sentidos (visão, tato, olfato...) para examinar as condições objetivas do mundo; ou por meio da recordação do que se sucedeu antes, em experiências similares.

Ainda considerando essa capacidade de formação do sujeito pelo que pulsa o desejo e desperta a curiosidade, foi possível perceber que, no MAR e na Casa da Ciência, os mediadores identificam a criança como sujeito autônomo para delinear os caminhos da visita de acordo com seu interesse e curiosidade. Leite (2005) enfatiza que oportunizar à criança delinear os caminhos da visita, conforme seu interesse, também é um aspecto importante na mediação com grupos infantis. Alerta que quando o educador (da escola ou do museu) se responsabiliza por conduzir toda a visita, a criança é introduzida a uma perspectiva de simples reconhecimento e identificação de elementos isolados. 
Muitas vezes vamos para a exposição decidindo "nós vamos para lá". E quando não sou eu, são os professores fazendo isso (...). Tenho tentado deixar o grupo decidir isso. Isso ocorre também porque, quando vamos trabalhar com Educação Infantil com crianças - entendemos que eles não têm condições de decidir autonomamente o que vão fazer dentro do museu porque são muito novos. Acho que isso é muito comum dentro das escolas, dos museus, dos centros culturais e de vários outros espaços (Entrevista - Maximiliano/Mediador do Museu de Arte do Rio).

Cada escola e cada criança é diferente, se quiser botar um roteiro para todas vai dar problema. Justamente por isso, deixar livre mesmo, se ela viajar e ver um zumbi no quadro "Retirantes", você tenta trazer aquilo ali, passar alguma informação e fazer uma troca com ela (Entrevista - Andrea/Mediadora Casa da Ciência).

\subsubsection{As constatações observadas na prática com crianças}

Após analisar o que os mediadores falavam sobre as crianças (nas entrevistas), trago as constatações da prática com as crianças que puderam ser percebidas ao longo da observação das visitas com turmas de E.I. nos espaços investigados. Os eixos norteadores da observação priorizaram a forma de atuação dos mediadores junto às crianças durante a visita; estímulo ao posicionamento crítico; oportunidades para que se expressassem livremente.

No que se refere à "atuação dos mediadores junto às crianças durante a visita", Carvalho (2011) e Leite (2005) destacam a importância de saber ouvir as perguntas, procurar responder de forma clara, coerente e verdadeira, sem infantilizar o discurso. Todavia, o que se vê, por vezes, é o uso frequente de linguagens infantilizadas na recepção às crianças.

Nas perspectivas de Benjamin (2017) e Vigotski (2003), a criança também é compreendida enquanto sujeito totalmente capaz de realizar uma interpretação dos fenômenos, ainda que, naturalmente, não possa explicar tudo.

Quando se fala a uma criança sobre um cavalo, que the parece gigantesco e enorme, chamando-o de "cavalinho", está sendo desfigurado o verdadeiro sentido da linguagem e a noção de cavalo, sem falar dessa atitude falsa e adocicada com relação a tudo o que se estabelece com esse sistema de fala. A linguagem é o instrumento mais sutil do pensamento. Se a desfigurarmos, estaremos fazendo o mesmo com o pensamento (VIGOTSKI, 2003, p. 241).

Nos museus investigados, em poucos momentos foi possível perceber os mediadores utilizando linguagem infantilizada, com excesso de diminutivos, para se dirigir às crianças. Na maior parte das observações, as crianças eram tratadas enquanto sujeitos plenamente capazes de ter experiências naquele espaço e de conhecer as temáticas abordadas.

No Museu Casa de Rui Barbosa, com o uso de uma linguagem simples, a mediadora abordava questões relevantes como: a importância da literatura, os direitos civis das mulheres, diferenças arquitetônicas das casas do passado e do presente, apresentação de mobiliários antigos, dentre outros. 
Rui Barbosa morava aqui nessa casa grandona olha como essa casa é diferente da casa em que moramos. Na sua casa tem um teto alto assim? (...). Antigamente, o teto era grande assim, agora o teto é mais baixo. Sabe por quê? Hoje, temos um monte de outros recursos para a casa ficar mais fresquinha, não é?! Tem ventilador, tem ar condicionado... Antigamente não tinha essas coisas. Construíam a casa com um teto bem alto para o vento poder ficar passando e ficar mais fresquinho (Caderno de Campo - Museu Casa de Rui Barbosa).

$\mathrm{Na}$ Casa da Ciência, a maioria das mediações também era desenvolvida de forma a perceber as crianças como sujeitos capazes de compreensão sobre o tema da exposição. Na exposição "Portinari e o Meio Ambiente", diálogos sobre seus sentimentos, impressões e experiências de vida foram abordados de forma simples e buscavam seguir a visita de acordo com os interesses do grupo, pelos quadros apontados. Na exposição “Aedes: que mosquito é esse?" tentavam estimular a curiosidade pela temática e pelos aparatos tecnológicos que compunham todo o espaço expositivo. Nessa exposição, especificamente, algumas crianças apresentaram apreensão e timidez com o espaço e com os mediadores - que souberam respeitar o comportamento particular dessas crianças, sem deixar de convidar e estimular cada uma a experimentar os espaços ao longo da exposição.

O nome desse quadro é "Retirantes". Retirantes são pessoas que saem do seu lugar, de onde moram, e vão para outro lugar. Alguém aqui já se mudou? Já mudou de casa? (...) Pessoal, a Ana falou que essa criança, no quadro, está gorda. Será? Ela notou que essa criança tem uma barriga bem grande. É por causa de uma doença que tem na água (Caderno de Campo - Casa da Ciência).

Já no Museu de Arte do Rio, a principal característica revelada nas práticas dos mediadores que atuavam na Instituição foi a percepção da criança como sujeito que brinca. A brincadeira, vinculada ao conteúdo/temática da exposição, foi o elemento central da maioria das visitas observadas ao longo do trabalho de campo. As ações dos mediadores demonstravam que entendiam as crianças como indivíduos que poderiam estar nos espaços museais e explorá-los de diferentes formas, subvertendo o entendimento de museu tradicional em que silêncio e ordem são essenciais.

De modo geral, nas três instituições, alguns aspectos não tão positivos na atuação com as crianças também foram detectados, como: formas de controle sobre o corpo e o comportamento nos espaços expositivos, a tentativa de transmitir uma "leitura correta da obra", a mediação despretensiosa referente ao reconhecimento da capacidade de leitura da obra e entendimentos sociais das crianças, ou, até mesmo, o uso de linguagens distantes/metafóricas que não ganhavam sentido no entendimento das crianças.

Na exposição "Portinari e o Meio Ambiente", da Casa da Ciência, alguns aspectos presentes na forma de mediação demonstraram que os mediadores, por 
vezes, desconheciam ou desconsideravam algumas especificidades da infância, como, por exemplo, o fato de (em todas as mediações acompanhadas), a cada obra observada no percurso expositivo, era solicitado que todas as crianças sentassem no chão em frente ao quadro a ser analisado. Essa estratégia era utilizada claramente como uma forma de evitar o deslocamento livre e ágil - "a dispersão" - das crianças pelo lugar, já que com outros grupos (ensino fundamental, ensino médio, público espontâneo) não era solicitado que sentassem para conversar sobre as obras.

Na Casa da Ciência e no Museu de Arte do Rio, em alguns momentos, também foi possível perceber que os mediadores tentavam estimular uma "leitura correta da obra". Atitude que, talvez, também fosse comum com os demais tipos de público, mas explicitou uma supervalorização do conteúdo em detrimento da leitura de mundo (mais autônoma) que as crianças poderiam fazer das obras.

Sobre essa forma de conduzir a mediação, Leite (2005) ressalta que buscar uma "leitura correta" das obras é desconhecer ou desconsiderar o fato de que o código linguístico de cada visitante sempre interfere em sua experiência. Nesse sentido, a obra sempre "fala" para o imaginário de cada criança de uma forma singular. Cada visita, cada experiência suscita sensações e indagações únicas, desperta desejos, abre portas para novas buscas - e isso não pode ser desperdiçado ou diminuído devido ao fato do público ser constituído por crianças.

Bem, isso é a Paz para o Portinari: crianças brincando em harmonia como vocês disseram. Quando vocês estão brincando, vocês se sentem felizes e alegres? (...) Brincar traz paz para vocês? [crianças afirmam que sim]. Então, essa era a definição de paz para Portinari (Caderno de Campo - Casa da Ciência).

Por vezes, a utilização da linguagem de forma metafórica (compreendida e respondida pelas crianças de forma literal), ou com vocabulário muito específico, deixava de fazer sentido e eram desperdiçados momentos propícios ao debate/diálogo no momento da visita

Mediador: Que animal é esse?

Criança: É um hipopótamo.

Mediador: É um hipopótamo? Será? Ninguém chuta outro bicho, não?

Crianças: Tio, eu chutei um gato uma vez. [nesse momento o mediador sorri, nada responde e a visita continua] (Caderno de Campo - MAR).

Mediadora: Estão vendo essa árvore grandona aqui no meio? Ela tem um nome diferente. Quem adivinha? Será que é uma mangueira?

Crianças: Não/ É uma árvore.

Mediadora: Mangueira dá qual fruta?

Crianças: Água. [referindo-se ao objeto de irrigar].

Mediadora: Água que dá na mangueira? Será o que dá na Mangueira, gente? Criança: Manga.

Mediadora: Muito bem, manga (Caderno de Campo - Museu Casa de Rui Barbosa). 
Vocês já tinham visto letras assim? Tão diferentes, tão peculiares? [Crianças olham para o mediador sem entender e não respondem - mediador, professores e crianças vão andando pela exposição e vendo algumas outras fotos] (Caderno de Campo MAR).

Foi também possível perceber práticas dicotômicas em uma única visita. No início, o mediador começou o trabalho demonstrando entender as crianças como sujeitos com capacidades distintas - colecionadores, com opinião diferenciada sobre o que é arte, expectativas diversas sobre o que poderia ser visto e aprendido no museu. Entretanto, ao explorar o acervo da exposição fotográfica, o mediador, em vários momentos, interrompeu a fala das crianças, e os questionamentos dirigidos indicavam que não considerava a possibilidade de que aquele grupo poderia ter algum conhecimento sobre o conteúdo da exposição. Fez perguntas relativas apenas aos aspectos físicos das fotos que as crianças conseguiam ver e descrever rapidamente, como cores, quantidade, objetos identificados etc. A postura do mediador tornou a visita entediante para as crianças, que ficaram um pouco dispersas.

Quantas escadas têm aqui? (...) Eu não quis dizer os degraus, eu perguntei quantas escadas. (...) Me mostrem aí [crianças vão apontando as escadas]. Aqui tem três escadas [crianças procuram as escadas na fotografia junto com o mediador]. Que cor é essa? (...) São três escadas de três cores diferentes. [A série de fotos, que retratava qualidades estéticas de favelas, eram repletas de significados e dialogavam com a realidade das crianças que também vinham de uma comunidade localizada na cidade Rio de Janeiro. No entanto, o mediador deteve-se a perguntar sobre quantidade de escadas e cores que as crianças podiam facilmente identificar nas fotos] (Caderno de Campo - MAR).

No que foi possível observar sobre "o estímulo ao posicionamento crítico das crianças e as oportunidades para a livre expressão", aferiu-se que, de modo geral, o posicionamento crítico e a expressão das crianças em relação ao que compreendiam das exposições eram estimulados pelos mediadores. Era comum que perguntassem o que as crianças viam, possibilitando descobertas e estimulando a criação de hipóteses, sem deixar de responder às dúvidas sempre que solicitados. Perguntas como "o que vocês acham que é?", "o que estão vendo?", "o que será que aconteceu?", "para que será que serve?" "alguém sabe?", eram frequentes nas falas dos mediadores.

Buscavam saber das crianças suas opiniões, impressões e posicionamentos e tentavam romper com o pensamento estereotipado sobre alguns temas. Outro aspecto interessante é que, geralmente, não havia a interrupção, por parte dos mediadores, nos momentos de fala e dos modos expressivos das crianças se comunicarem - com seus pares, com os mediadores e com as professoras. Conforme mostra o trecho abaixo, além de tentar compreender o que as crianças 
estavam pensando sobre o conteúdo expositivo, os mediadores buscavam estimular as possibilidades de leitura de mundo.

Mediador: [entrando na exposição] Lembram que eu falei para vocês que entrando aqui eu ia contar uma história de alguns índios? A Eduarda disse que viu um índio na novela, alguém disse que viu um índio na Xuxa. Será que esses índios que vocês viram vão ser os mesmos daqui? Dessa história? Será? Como era o índio que você viu, Eduarda? Como ele se vestia.

Criança: Como um índio.

Mediador: Como é se vestir como um índio? [criança fica tímida e olha para a professora].

Professora: Eu não vou te dar "cola" não. Ele tinha o que na cabeça?

Criança: Ele usava um arco na cabeça e saia.

Mediador: Só isso? Será que todos os índios...

Criança: Ele tinha tinta também.

Mediador: Tinta pintada no corpo?

Crianças: Sim. Uma tinta verde, branca e uma tinta vermelha.

Mediador: Ah, legal! Quero perguntar uma coisa para vocês: Será que todos os índios se vestem de maneira igual? Será? Será que todos são iguais? Será que não existem índios diferentes?

Crianças: Sim!

Mediador: Olha, eu vou mostrar alguns índios para vocês (...). Tem um povo aqui chamado Pataxó e o outro chamado Purí. Mas vamos conhecer uma história lá de trás, de muito tempo atrás, que conta a história de todos os povos indígenas. Vamos lá? (Caderno de Campo - MAR).

Também foi possível constatar, em uma visita de E.I ao MAR (que excedeu o número de crianças informado pela escola), que o mediador (um pouco atordoado) tentava controlar a participação do grupo com o uso recorrente de solicitações como "vou pedir para levantar a mão também quando for falar" e "fala rapidinho porque também tem muita gente pra falar".

Sobre essas atitudes dicotômicas na recepção ao público infantil, Oliveira (2011) reitera que é fundamental escutar as crianças para que, de fato, a visita ocorra de forma a promover tempo e espaço para observar e imaginar diante dos objetos que despertam o interesse, sem ter que "olhar outra coisa" por solicitação dos adultos. Para a autora, escutar as crianças significa também estar atento àquilo que olham e como olham dentro dos espaços museológicos - observar como se movimentam, seus gestos e significados atribuídos, os sussurros, os comentários, as brincadeiras e mesmo o que não desperta o interesse. $O$ foco de atenção pode, inclusive, não ser o acervo, mas a arquitetura ou outros elementos do espaço. Salienta que a balbúrdia, o vibrar comum das crianças, interpretado como barulho e ruídos em uma visão conservadora, é propício para a aprendizagem e manutenção do interesse: deve ser interpretado como sentir em uníssono, compartilhamento da experiência estética. 


\section{2.}

\section{Crianças e a experiência museal}

Reddig (2007) e Fallon e Chavepeyer (2013), analisando a forma como a infância é representada nos diferentes espaços museológicos, concordam que os museus são repletos de bebês e crianças pequenas "penduradas nas paredes em quadros ou esculpidas em pedra e mármore" (FALLON e CHAVEPEYER, 2013, p. 03). Os visitantes contemplam essas crianças e se comovem. Já as crianças de verdade nem sempre são bem-vindas, pois, a princípio, não dominam os códigos habituais de conduta nesses lugares. "Podem correr por toda parte, gritando, rindo, chorando, babando, jogando-se no chão, podem precisar comer urgentemente, ou até achar um extintor de incêndio mais interessante que uma pintura" (ibidem).

Entretanto, ao observar mais de perto a relação que as crianças podem estabelecer com os espaços museológicos, essa maneira de enxergar o público infantil pode ser modificada e as barreiras na recepção a esse público, rompidas. Carvalho (2016), ao investigar públicos escolares de diferentes segmentos nos museus, pôde perceber que a participação das crianças pequenas é, em geral, muito ativa e atenta ao que veem - indagam sobre as obras, questionam a todo tempo, interrompem quando não entendem, têm dúvidas e querem tecer seus comentários.

A partir do reconhecimento da potencialidade das crianças e de sua compreensão enquanto sujeitos históricos e culturais, os museus, lugares que guardam o conhecimento produzido por toda a "Terra que está repleta dos mais puros e infalsificáveis objetos da atenção infantil" (BENJAMIN, 2017, p. 57), podem estabelecer uma relação profícua com esse público, explorando temáticas distintas com a qual se relacionam.

Dentre as inúmeras possibilidades a serem exploradas, é preciso distinguir a especificidade da experiência coletiva quando as crianças visitam os museus com a escola. O passeio em si já é suficiente em termos de novidades a serem assimiladas: sair para o desconhecido sem a família, perder as referências, pegar o ônibus, ver o caminho percorrido pela cidade, chegar a um espaço arquitetônico que muitas vezes é suntuoso e, ainda, a peculiaridade de viver tudo isso acompanhado de outras crianças e não apenas de adultos. Reconhecer a importância dessa experiência coletiva significa perceber o papel fundamental das interações sociais para a construção do conhecimento em meio à formação cultural das crianças. Sobre esse aspecto se funda a relevância de visitar os museus com o cenário escolar - possibilitar a interação com professores e pares 
de forma a construir significados coletivos e o compartilhamento dos aprendizados (MOURA, 2011; FALLON e CHAVEPEYER, 2013).

Levando em consideração esse apontamento da literatura, um dos aspectos investigados nesta pesquisa foi buscar compreender como as crianças reagem à experiência de visitar museus de diferentes tipologias com suas escolas: O que dizem? Como se comportam? O que desperta maior interesse? Quais conhecimentos e interpretações conseguem articular?

\subsection{1.}

\section{Expectativas, reações e os principais interesses das crianças nas exposições}

Atenta às reações que escapavam, ao modo como reagiam e às falas proferidas entre si, com os mediadores e com os professores, foi possível perceber que as crianças possuíam um entendimento sobre o que pode vir a ser um museu e o que esse local pode guardar. Algumas crianças, como na Casa da Ciência, revelaram que foram informadas previamente sobre a visita. Já nas visitas realizadas no MAR, o elemento surpresa foi mais presente.

As expectativas das crianças, nas três instituições, giravam em torno do museu como local de infinitas possibilidades e aventuras a serem desbravadas. Quando questionadas sobre o que achavam que iriam encontrar dentro dos museus, dentre as diversas possibilidades de coisas fantásticas, o encontro com dinossauros era sempre uma hipótese presente nos grupos.

Mediador: Nesse lugar, vamos procurar uma coisa que eu quero saber se vocês conhecem.

Crianças: Um avião / É uma baleia / Dinossauro / Um peixe / Um gigante / Eu já sei! É bem um tiranossauro Rex (Caderno de Campo - Museu de Arte do Rio).

As falas das crianças revelaram que o museu também é compreendido como lugar que guarda quadros e coisas antigas como mobiliários, louças etc. Quando um mediador pediu para que desenhassem o que achavam que iriam encontrar dentro do museu, as crianças revelam "Eu desenhei copos / Eu desenhei quadros / Mesa / Cadeiras / Fotos" (Caderno de Campo - Museu de Arte do Rio).

Mediador: Museu serve para que?

Crianças: Para ver artes / Pra contar história / Pra comer comida / Pra ver as coisas antigas (Caderno de Campo - Museu de Arte do Rio).

Algumas noções sobre normas de conduta socialmente esperadas também foram mencionadas pelas crianças. Entendimentos sobre o que não era permitido foram os mais presentes. Conforme demonstra o trecho abaixo, era comum que 
os mediadores tentassem romper com a concepção de museu como lugar de proibições.

Mediador: Vocês sabiam que quando nós vamos ao museu tem três coisas que não podemos fazer? Vocês sabem o que é?

Criança: Comer.

Mediador: Isso, não podemos comer no museu. Muito bem!

Crianças: Não pode comer/ Nem brincar/ Nem correr.

Mediador: Mas nós corremos, brincamos, pulamos... Será que isso não pode fazer? Criança: Gritar.

Mediador: Mas nos pulamos e gritamos. Não vamos poder o quê?

Criança: Mas a gente não pode pular.

Mediador: Ah, mas aí é para vocês não se machucarem, mas não é uma regra do museu.

Criança: Se a gente pular quebra o chão e vai fazer um buracão.

Mediador: Sabe quais são as regrinhas? Não pode comer nada, nem beber. A outra regrinha é que não pode tocar nas obras e tem a regrinha também que não pode tirar foto com flash. Tirar foto com flash faz com que a obra vá se destruindo com o tempo, sabia? (Caderno de Campo - Museu de Arte do Rio).

No que concerne ao interesse pelo que era visto, foi possível perceber que, independente da tipologia do museu ou da temática abordada, o conteúdo expositivo atraia a atenção das crianças.

No Museu de Arte do Rio havia três exposições em cartaz na época da realização do trabalho de campo. Na exposição indígena "Dja Guata Porã", as crianças demonstraram grande interesse pelo acervo composto por esculturas, vídeos e objetos indígenas. Alguns eram conhecidos pelas crianças como arco, flecha e animais. Além da curiosidade sobre o acervo, as brincadeiras que se relacionavam com a fauna das matas brasileiras e com as músicas com instrumentos indígenas tiveram grande participação das crianças. Havia uma auto-organização dos grupos para que todos pudessem tocar e sentar no que era disponibilizado como acervo tátil, faziam tentativas de acertar quais eram os animais que viam, compartilhavam suas surpresas e encantamentos com seus colegas. Tônicas e questionamentos como “Uaaaau, olha isso!”, “O que é isso?”, "Pode mexer?", "Deixa eu ver!" eram recorrentes. Na exposição fotográfica "Feito Poeira ao Vento" demonstravam interesse em algumas fotos que conseguiam relacionar com temas do cotidiano. Já na exposição "Dentro", podiam tirar os calçados e fazer movimentos que exploravam o corpo de diferentes formas. Nesse momento evidenciavam estar muito à vontade com os mediadores e com o espaço do museu.

Uma reação também comum nos grupos que visitaram a Instituição foi o encantamento com o espaço e com a arquitetura do local. No terraço do Museu, relatavam para os colegas e para o mediador o que viam lá embaixo, o máximo que suas vistas conseguiam alcançar. Eram capazes de observar diferentes 
elementos da paisagem na Praça Mauá como o VLT, estátuas, relógios e até mesmo o mar e a poluição que havia na água.

No Museu Casa de Rui Barbosa, de modo geral, os três momentos da visita (contação de história, visita ao Museu-Casa e ao Jardim Histórico) despertaram o interesse das crianças. No Jardim - por ter mais espaço e poderem se locomover sem o controle das professoras - as crianças demonstraram estar mais à vontade. Também expressaram interesse pela natureza local com pequenos animais (peixes, formigas, pássaros), aventuraram-se ao atravessar uma ponte sobre o lago e tiveram a oportunidade de participar de brincadeiras mais agitadas como a caça às esculturas. Uma criança deu especial atenção aos mapas que encontrava pelo Jardim, provocando a curiosidade dos colegas. A mediadora aproveitou o momento para observar o mapa com as crianças e retomar a visita feita à Casa. Nesse momento, as crianças foram relembrando coletivamente todo o percurso realizado.

$\mathrm{Na}$ Casa da Ciência, foi possível perceber que o foco principal de interesse das crianças residiu nos elementos da natureza que compunham as duas exposições que ocorreram ao longo do ano. $\mathrm{Na}$ exposição "Aedes: que mosquito é esse?", mesmo com todos os módulos interativos, as crianças se detiveram um tempo maior observando o conteúdo dos microscópios que continham as etapas do desenvolvimento morfológico do inseto (ovos, larva, mosquito etc). Já na exposição "Portinari e o Meio Ambiente", os quadros eram, em sua maioria, os objetos mais presentes na exposição e o foco da atividade de mediação. Contudo, as crianças também demonstraram grande interesse pelos elementos naturais que compunham a expografia (dispostos abaixo dos suportes em que estavam as obras) como carvão, areia, terra, plantas etc.

Os aparatos tecnológicos presentes nas exposições do Museu de Arte do Rio e na Casa da Ciência, também foram alvo de interesse das crianças. Na Casa da Ciência, toda a exposição "Aedes: que mosquito é esse?" era composta por módulos interativos que dispunham de aparelhos tecnológicos e científicos em que as crianças eram estimuladas ao manuseio e apropriação dos conteúdos apresentados. Já a exposição "Portinari e o Meio ambiente" continha alguns ambientes acolhedores com pufes e vídeos sobre o artista, mas esses recursos não foram abordados pelos mediadores em nenhuma das visitas acompanhadas. Ainda assim, as crianças tentavam ver o conteúdo e, frequentemente, as professoras intervinham para que escutassem apenas os mediadores. No Museu de Arte do Rio, a exposição "Dja Guata Porã" continha televisores com fones de 
ouvido expostos à altura das crianças, exibindo rituais e depoimentos de diferentes tribos indígenas, que puderam ser assistidos sempre que desejavam.

Oliveira (2011), refletindo sobre convocações multissensoriais, considera que essas tecnologias eletrônicas empregadas na arte são mais uma estratégia, entre tantas outras, em que é possível atuar com o propósito de produzir situações para que os sujeitos sejam motivados a construir significações para si mesmo e para o mundo. Alerta que, muitas vezes, o que se tem presenciado é a utilização de tecnologias feitas mais para criar ideias do que emoções. Repletos de conceituações, mas restringidos de atuar como sensibilizadores, esses recursos empobrecem a possibilidade de manifestação estética. A autora argumenta que o propósito de estimular emoções de caráter estético deve ser priorizado no uso de tecnologias em obras e ambientes artísticos, ou seja, buscar criar emoções independente de teores de verdade, de utilidade e de satisfação sentimental. Ressalta que ainda é preciso tempo para que os fruidores aprendam a conhecer as possibilidades da arte tecnológica e, por meio deles, as próprias obras.

Nas três instituições, as crianças demonstraram entrosamento e uma relação interativa com os mediadores e com suas propostas ao longo das visitas. Sentiam-se à vontade para fazer perguntas relacionadas ao que viam, imaginavam ou suspeitavam. No Museu de Arte do Rio, especialmente, ficavam envolvidas com as atividades e brincadeiras sugeridas e entravam no faz-de-conta estimulado pelos mediadores em diversos momentos.

Criança: Eu achei! Vem cá! Vou te mostrar [criança pega na mão do mediador de forma a conduzir ele e a turma em uma caçada sorrateira. Vão andando abaixadas, devagar, se escondendo e esquivando pelo acervo e sussurrando atrás da onça].

Mediador: Caramba! Ainda não achamos. Vamos cantar de novo a música da onça para ver se achamos?

Mediador e Crianças: "Eu vi uma onça gemer na mata do Arvoredo" [todos rugem]. Crianças: Acho que a onça está lá! / É! É a nossa onça. [observam o objeto empolgadas]

Criança: [põe a mão dentro boca da escultura em formato de onça] Ai ela me mordeu! [algumas crianças ficam assustadas].

Mediador: Não morde não, porque essa onça é bem boazinha, não é?!

Criança: Pois é, ela não morde nada [conta gargalhando aos colegas que ficaram assustados] (Caderno de Campo - Museu de Arte do Rio).

Conforme abordado por Vigotski (2009), para a formação e constituição da criança, a atividade criadora da imaginação age por meio da formulação de hipóteses a partir do que já sabe (de suas experiências anteriores) e do que pode vir a ser. Essa é uma condição que ocorre sempre que a criança não é subtraída a uma postura de reprodução. Richter (2011) coaduna com a perspectiva e, refletindo, especificamente, sobre a atividade criadora da imaginação no faz-deconta, esclarece que este é um exercício fundamental que a criança realiza de 
forma lúdica, exercitando a aventura da criação de uma situação que satisfaça seu desejo. O acervo da exposição "Dja Guata Porã”, por diversas vezes, serviu como material para o faz-de-conta e contribuía para enriquecer o imaginário da fantasia das crianças, que descobriam a possibilidade de criar novas formas e significações a partir dos objetos vistos. Sobre essa perspectiva, Richter (2011) amplia a reflexão ao elucidar que real e imaginário são indissolúveis e o pensamento da criança se desenvolve a partir do jogo entre fantasia e realidade, onde tudo que vê e vive é passível de ser transmutado. Nesse sentido, a imaginação é a ferramenta que sustenta o sentir e o raciocínio e, por meio de ambos, a criança cria construindo um imaginário social, constituído de cultura e na cultura e o faz-de-conta é ferramenta fundamental nesse processo. Essa disponibilidade da criança de apreender o mundo por meio do jogo e abertura à transmutabilidade dos elementos da cultura, Vigotski (2003) considera que é essencial ao desenvolvimento da experiência estética, criando possibilidades diversas de questionamento da realidade existente e vivida.

No contato com o acervo, as crianças faziam leituras criativas sobre o que viam. Deixavam curiosidade e imaginação fruírem de forma a enxergar novos detalhes e construírem outras narrativas para as obras que, até então, não haviam sido consideradas pelos mediadores e professores. Mediador: Então os animais têm que estar livres, certo? Na floresta e não presos.
Crianças: Isso! / Imagina só se o bico do passarinho fosse uma furadeira. Ele ia
poder fugir [da gaiola]! (Caderno de Campo - Casa da Ciência).

Eu quero que vocês encontrem três relógios aqui de cima [as crianças acham dois relógios.]. Está faltando um! [crianças acham 2 relógios a mais] Nossa! Vocês acharam mais um relógio. Esse quarto relógio eu nunca havia reparado (Caderno de Campo - Museu de Arte do Rio).

Por vezes, as crianças também apresentavam falta de interesse nas atividades propostas pelos mediadores. No Museu de Arte do Rio, em um grupo de E.I observado, o mediador utilizou como metodologia principal a contação de história de vários contos indígenas e, ao longo da visita, as crianças foram perdendo o entusiasmo.

Mediador: Agora vamos sentar aqui nesse tapete [Tapete de Histórias Puri] que eu vou contar uma história para vocês. É um conto indígena.

Criança: [crianças que estavam fazendo a visita com outro mediador entram correndo na exposição] A gente quer correr também.

Mediador: Daqui a pouco a gente corre [e continuou contando a história enquanto as crianças observavam a mediação do outro grupo]" (Caderno de Campo - Museu de Arte do Rio).

Examinando essa situação em que a narrativa proposta pelo mediador não foi capaz de gerar o interesse do grupo, os estudos de Dewey (2002) esclarecem 
que, sempre que um novo assunto é abordado com a criança, uma experiência tem de afetá-la de forma imediata, caso contrário, ela não se mostra suficientemente interessada em compará-la ou relacioná-la com as experiências vividas por ela ou por outras pessoas. Por isso, é comum que respondam "eu já vi isso" ou "meu pai e minha disseram isso", pois o seu horizonte ainda não é amplo. Entretanto, adverte que esse interesse, a princípio "egoísta e limitado" da criança é passível de se expandir indefinidamente.

O autor elenca quatro categorias de impulsos que despertam o interesse das crianças: (i) impulso social ou de linguagem; (ii) impulso de fazer ou construtivo - expresso nas brincadeiras e na manipulação de objetos e materiais; (iii) impulso investigativo - relação entre mexer em coisas e observar o que acontece e (iv) impulso expressivo ou artístico - que é o refinamento e a manifestação plena dos impulsos comunicativo e construtivo, relacionado ao desejo de relatar e representar. Considera que saber respeitar e estimular essas especificidades que geram o interesse das crianças é tarefa importante da educação. Desta forma, compreende-se que a análise e a aplicabilidade dessas categorias devem ser levadas em conta ao se elaborar práticas que busquem promover experiências educativas às crianças, seja na escola, nos museus ou em distintos espaços.

O êxito que se obtêm quando se estimula esses impulsos que despertam o interesse das crianças, elencados pelo autor, pôde ser percebido na realização da mesma atividade (contação de história) no Museu Casa de Rui Barbosa. A visita começava com uma contação de história, dando preferência aos livros da literatura nacional brasileira. A todo momento as mediadoras estimulavam a participação do grupo que tentava adivinhar qual era o personagem misterioso do livro apresentado. As crianças buscavam na memória animais que tivessem as características indicadas na literatura. Ficavam extremamente empolgadas nessa tarefa e interagiam entre si, com as mediadoras e com as professoras.

Em momentos contrários, onde os grupos eram submetidos a formas de controle, as crianças demonstraram incomodo e cansaço. Como na Casa da Ciência, em que os mediadores solicitavam, apenas para as crianças, que a cada obra observada todas se sentassem, no chão, em frente ao quadro. E, em um dos grupos observados, que a professora recomendava que, na locomoção pelo espaço, todas as crianças andassem de mãos dadas com sua "dupla".

Sobre essas práticas de controle, como andar em fila, dar as mãos ou manter a criança por longo tempo sentada para que observem os objetos dos museus, é importante recordar que a percepção do mundo para as crianças se dá 
pelos sentidos. Fallon e Chavepeyer (2013, p. 05) reiteram que além da "extraordinária acuidade sensorial, a criança pequena também é um ser motor: o movimento é vida". Portanto, querer manter as crianças quietas, por muito tempo, além de gerar conflitos no grupo, pode ser um fator de empobrecimento da experiência.

Em meio à descoberta dos diferentes espaços dos museus - que eram amplos e cheio de aventuras a serem desbravadas - algumas crianças demonstraram medo. Nesses momentos, o apoio e a empatia entre pares foram fundamentais para que as crianças que estavam receosas se arriscassem a entrar e explorar os ambientes.

Crianças: Olha que legal, a gente vai atravessar uma ponte / Caramba! / Eu tenho medo. / Vamos lá, vem! [criança dá a mão para ajudar o colega com medo a atravessar a ponte no jardim] / Olha, aqui embaixo tem peixe/ E passarinho (Caderno de Campo - Museu Casa de Rui Barbosa).

Professora: Ele está com medo de tudo. Foi por isso que eu fiz questão de trazer ele. Ele não sai de casa, da comunidade. É engraçado perceber a diferença, porque na escola ele é todo alegre e aqui ele tem medo de tudo! (Caderno de Campo Museu de Arte do Rio).

Criança: Cadê o urso? [pergunta assustado]

Mediador: O urso já foi embora, ficou lá na caverna!

Criança: Era só um negócio assim... para a gente fingir que teve. [criança fala para a colega tentando acalmá-la] (Caderno de Campo - Museu de Arte do Rio).

Essa postura solidária adotada pelas crianças para desvendar os museus pôde ser observada no MAR e também no Museu Casa de Rui Barbosa. No museu histórico algumas crianças achavam a Casa escura e estranhavam alguns quadros antigos, já no museu de arte o medo do encontro com o desconhecido no espaço amplo era mais recorrente. A solidariedade e a empatia entre as crianças foram percebidas de forma similar nas duas instituições - davam as mãos, proferiam palavras de apoio e esclareciam situações aos colegas.

Dewey (2002) salienta que por trás de todos os comportamentos visíveis da criança que experimenta esteticamente a cultura há o reajustamento de sua postura mental em uma perspectiva alargada e solidária, a consciência como poder crescente e a ampliação da capacidade de discernimento e das aptidões individuais com os interesses do mundo. Para o autor, trabalhar com a cultura de forma consistente é, seguramente, "o desenvolvimento da imaginação em termos de flexibilidade, âmbito e solidariedade" (DEWEY, 2002, p. 58). Nessas atitudes solidárias entre as crianças que se relacionavam com a cultura material dos museus, foi possível captar sinais dessa contribuição para a formação humana resultante da experiência estética vivida. 
4.2.2.

Interpretações articuladas entre o conteúdo das exposições e o conhecimento de mundo

Outro aspecto da experiência estética vivida pelas crianças nos espaços museais, possível de ser captado, foi a articulação de saberes sobre a temática das exposições que as crianças conseguiam realizar tendo como alicerce o conhecimento de mundo que traziam consigo. Dewey (2010) considera que a experiência estética ocorre quando o espectador, assim como o criador da obra/objeto, passa por um processo de ordenação dos elementos de forma conjunta - entre o que é percebido e a bagagem de conhecimentos provindos das experiências anteriores do sujeito. Sem um ato de recriação daquele que vê, o produto artístico não é percebido como um objeto estético. $O$ artista faz o trabalho de escolher, simplificar, esclarecer, abreviar e condensar tudo em determinada obra/objeto de acordo com seu interesse. Aquele que olha também precisa passar por essas etapas de acordo com seu ponto de vista e interesse. Desta forma, para ambos, ocorre o trabalho de percepção, de abstração e de extração daquilo que é significativo - uma reunião de detalhes e particularidades de conhecimentos anteriores dispersos que se reúnem em um todo vivenciado.

Nas visitas observadas, a partir do que viam nas exposições e no diálogo com os mediadores e com os professores, as crianças demonstraram inúmeras articulações de conhecimento sobre os diferentes conteúdos dos três museus investigados. Identificaram cores, objetos e formas geométricas. Expuseram seus entendimentos sobre casas, mobiliários, temática indígena, diferentes animais, plantas, frutas, preservação do meio ambiente, o respeito à fauna e à flora, dentre outros assuntos. As interpretações que faziam partiam da relação que estabeleciam com suas experiências anteriores e conhecimentos prévios adquiridos no âmbito familiar e escolar.

Criança: Que vaso é esse aqui? [fica impressionada com um vaso em meio a outros que estavam na sala]

Mediadora: É um vaso que veio lá do Japão.

Criança: Eu já vi coisas lá do Japão que soltam fogo (Caderno de Campo - Museu Casa de Rui Barbosa).

Criança: Tem árvores cortadas [observando um quadro de Portinari].

Mediador: E aquele vermelho ali parece o quê?

Crianças: Sangue! / Árvore tem sangue?

Mediador: Pois é, na arte ele [Portinari] usou isso para representar o sofrimento das pessoas com essa terra seca.

Criança: Ah, já sei! Ele usou isso porque algumas pessoas morreram naquele lugar! Mediador: Com certeza, muitas pessoas!

Criança: E caíram em cima desse chão. / O sofrimento da árvore também.

Mediador: O sofrimento da árvore também. Vocês acham que a gente precisa da Terra para sobreviver? Aqui no Rio de Janeiro a gente precisa? 
Crianças: Sim/ E precisamos também do coração/ Da água/ Do sol (Caderno de Campo - Casa da Ciência).

Mediador: É uma lagoa seca?

Criança: É, acabou a água.

Mediador: E se as sombrinhas [guarda-chuvas] fossem animais? Que animais seriam?

Crianças: Um sapo que tá na lagoa/ Peixe/ Tubarão/ Vitória Régia.

Professora: Ai, eu já ia falando animais terrestres! Eles estão certos, tem que ser os animais que moram na água mesmo (Caderno de Campo - Museu de Arte do Rio).

Foi possível identificar na fala de algumas crianças o entendimento que possuíam sobre o que é arte e as relações que já conheciam acerca de algumas técnicas artísticas. Demonstraram familiaridade com algumas técnicas de desenho, como o traçado com o uso de carvão, bem como domínio de informações sobre obras de arte nas etiquetas que ficam ao lado dos quadros.

Mediador: E o que é arte?

Crianças: Pintura/ Criatividade/ Pintar/ Pintar com tinta/ É fazer bagunça/ Não! Bagunça é bagunça!

Professora: E as esculturas?

Crianças: Sim! / Esculturas também.

Mediador: E foto? Foto é arte?

Crianças: É/ Sim/ Não/ Não é.

Mediador: É ou não é?

Crianças: É sim! [chegam a um consenso] (Caderno de Campo - Museu de Arte do Rio).

Mediador: Embaixo de todas as obras conseguimos saber qual foi o material que ele usou para fazer esse desenho, qual foi a tinta que ele usou.

Criança: Dá para saber também o nome.

Mediador: Isso! Então tudo tem aqui e até o lugar onde vocês podem ver a original porque essas aqui não são originais, são réplicas.

Criança: São falsas?

Mediador: Não. Não são falsas, são réplicas. Elas são digitais, feitas com uma tecnologia que vem de Israel - bem longe. É uma tecnologia muito séria que pinta direitinho de acordo com que está no quadro original para a gente poder levar para todos os lugares (Caderno de Campo - Casa da Ciência).

$\mathrm{Na}$ Casa da Ciência, conforme explicitado nos trechos abaixo, as crianças também expuseram um entendimento das obras a partir de um olhar sensível para as diferentes linguagens artísticas que retratavam o sofrimento, a morte e a miséria.

Mediador: Ana Clara leu que o nome desse quadro é o vendedor de passarinhos. É legal isso?

Crianças: Não! [todas respondem negativamente] / É uma maldade! / Por que existe vendedor de passarinhos? [exclama retoricamente indignada] / Lá em Campos quando o passarinho estava com a asa meio ruim e pousou lá na casa da minha avó, em Atafona, a gente colocou a água para ele e comida e ele não conseguiu, aí no dia seguinte ele já tinha morrido (Caderno de Campo -Casa da Ciência).

Mediador: Quando Portinari pintou, esse rio era limpo. Hoje o rio está sujo, por quê?

Crianças: Porque não tão ligando para nada!

Mediador: É! Porque as pessoas estão jogando lixo nele. 
Crianças: Eu já vi um golfinho que comeu uma tampa de garrafa e morreu (Caderno de Campo - Casa da Ciência).

No Museu Casa de Rui Barbosa, demonstravam curiosidade pelos objetos do acervo (vestuários, mobiliário, quadros etc.) e observavam aspectos da arquitetura, sinalizando diferenças das casas em que viviam. As perguntas eram constantes. A cada novo ambiente, indagavam quem eram as pessoas pintadas nos quadros, a utilidade dos móveis que desconheciam, relatavam suas impressões e buscavam resgatar conhecimentos de suas experiências anteriores.

Em uma sala, que continha vasos antigos, uma criança encantada pelos desenhos de um dos objetos, pergunta "De onde é esse vaso?", e a mediadora responde: "Esse vaso veio lá do Japão" e outra criança cria sua hipótese: "Esse não era do Rui, ele não era do Japão" (Caderno de Campo - Museu Casa de Rui Barbosa).

No Museu de Arte do Rio, também foi possível perceber que as crianças faziam reflexões sobre o que viam nas exposições e sobre o que conheciam. Observavam as obras, faziam perguntas, expunham suas impressões, relacionavam seus saberes do cotidiano com o que viam nas fotografias e criavam suas hipóteses sobre o acervo indígena. Faziam observações e interpretações com seus pares e com o mediador - concordavam, discordavam, experimentavam outros pontos de vista.

Mediador: [contando uma história indígena] $\mathrm{E}$ sabe quem encontrou a cutia? Dois índios, mas eram dois índios crianças que a gente chama de Curumim.

Criança: Eu conheço!

Mediador: Conhece Curumim?

Crianças: Sim! Porque lá na escola foram os índios.

Mediador: Olha, que legal! Então, foram essas crianças indígenas, chamadas curumins, que encontraram a cutia que estava com muita fome.

Criança: Eu tenho um livro que tem curumim.

Mediador: Que bacana! (...)

Criança: O pai deles [curumins], que você falou, o nome é Pajé.

Mediador: Olha que legal! É isso mesmo, é um Pajé (Caderno de Campo - Museu de Arte do Rio).

Dewey (2002) considera que quando a criança consegue expressar, de forma eloquente, a quantidade de informações que conseguiu assimilar de determinado assunto, diante de outros (professor, adultos, colegas), esse momento se caracteriza como um encontro social. Para o autor, quando o impulso verbal da criança é socialmente estimulado, há um contato contínuo com a realidade. E, como resultado, a criança tem pensamentos que quer exprimir, o desejo social de relatar suas experiências e de ouvir as experiências de outros. Esse momento pode ser compreendido enquanto uma espécie de câmbio social onde as experiências e ideias são compartilhadas, sujeitas a críticas e é possibilitado o delineamento de novas linhas de pensamento. 
Leite (2005) coaduna com a perspectiva e ressalta que, apesar do frequente enquadramento comportamental imposto ao público infantil nos museus, em sua capacidade de subversão da ordem, de transgressão, as crianças conseguem mergulhar em suas próprias experiências contemplativas exercendo o papel de sujeitos, capazes de fazer emergir no grupo ideias e compreensões singulares. Nesse sentido, fica visível que a criança contempladora é sujeito-interlocutor da obra, pois coloca em jogo seus referenciais e todo o seu conteúdo de significações para construir o entendimento da obra com a qual interage.

Um aspecto a ser valorizado para que essa experiência da dimensão estética das crianças de fato aconteça é o reconhecimento de suas capacidades de interpretação e de viver uma experiência sensível. A emoção estética faz parte da natureza humana, não é, portanto, exclusiva de uma elite sábia e cultivada. Os objetos artísticos oferecem formas e linguagens para que o indivíduo dialogue consigo a partir da interpretação, da significação e da recriação de sentidos. O sentimento despertado nesse encontro faz o sujeito ir além - desperta a curiosidade e a pluralidade de percepção e compreensão. Nesse sentido, é importante que as crianças tenham experiências com múltiplas representações das formas de viver e estar no mundo, em distintas épocas. No encontro com os objetos expostos nos museus, em meio à linguagem expositiva e à leitura de mundo compartilhada entre os diferentes agentes da visita, a criança pode relacionar emoções, pensamentos e experiências. Desta forma, suas descobertas, percepções e compreensões são enriquecidas (GABRE, 2016; FALLON e CHAVEPEYER, 2013).

\section{3.}

\section{Professores de educação infantil e práticas educativas nos museus e centros culturais}

Oliveira (2011), analisando a relação entre museus e público infantil, ressalta que ainda é comum o entendimento de que as crianças vão ao museu apenas para brincar. Além de não acreditar na capacidade de as crianças compreenderem e se relacionarem com o conteúdo do que é exposto, esse tipo de pensamento desconsidera que a brincadeira é a forma como as crianças compreendem e criam cultura, se apropriam dos saberes produzidos local e globalmente. Nesta perspectiva, constata-se a baixa frequência do público infantil nos museus, seja por parte dos acompanhantes que não levam as crianças, ou dos museus que ainda não incluem esse público em sua programação.

Quando um museu resolve receber crianças em seu espaço, é preciso compreender que também está abrindo suas portas aos adultos que as 
acompanham. Esses adultos precisam ter confiança na possibilidade do encontro entre as crianças e os museus (espaço, acolhimento, profissionais, atividades, segurança etc.). Diante da multiplicidade de objetos e obras que não são familiares, aqueles que não tiveram a oportunidade de se apropriar dos museus e centros culturais desde cedo, se não dominam seus conteúdos, podem se sentir excluídos e, principalmente, não acreditam na possibilidade de as crianças pequenas também se apropriarem desses espaços (FAALON e CHAVEPEYER; SHAFFER, 2015).

Conforme exposto no subcapitulo 3.2 "Quando os pequenos cariocas visitam os museus e centros culturais da cidade", nos museus do município do Rio de Janeiro, o principal responsável por promover o encontro do público infantil com esses espaços é a escola. Desta forma, foi preciso investigar como os professores, agentes na promoção desse encontro, compreendiam e participavam da relação estabelecida entre o público de Educação Infantil e os museus.

Os professores que participaram das visitas observadas possuíam o hábito de frequentar museus? Costumavam levar suas turmas de E.I a museus e centros culturais com frequência? Essa prática foi estimulada na formação? Possuíam preferência por algum tipo de museu para visitar com suas turmas? O que pretendiam proporcionar às crianças com a visita? Consideraram as visitas relevantes? Em qual sentido? Como se relacionavam com o conteúdo das exposições, com os mediadores e com as crianças?

Buscando responder a essas questões, ao final de cada visita observada nos museus investigados, foi realizada entrevista com, pelo menos, um professor de cada grupo de E.I. Os achados da pesquisa se configuraram da seguinte forma: (i) os professores de Educação Infantil e a prática de frequentar museus, (ii) a percepção dos professores sobre a relação entre museus e crianças e (iii) as relações estabelecidas pelos professores durante a visita.

\subsection{1.}

\section{Os professores de Educação Infantil e a prática de frequentar museus}

Com o objetivo de identificar a relação estabelecida pelos docentes com os museus e centros culturais, foi investigado se os professores possuíam o hábito de visitar museus fora da prática profissional e se, na sua formação docente, houve algum estímulo para frequentar esses espaços.

Sobre o hábito de frequentar museus fora de sua prática profissional, dos quatorze professores que participaram da pesquisa, onze informaram que possuíam esse hábito. De acordo com os relatos, apesar do pouco tempo para as práticas culturais, a frequência a esses espaços é relacionada a uma atividade 
cultural que gostam. Duas professoras revelaram que visitar museus e centros culturais é um hábito que foi iniciado devido à prática docente. Ou seja, o ato de levar suas turmas ao museu fez com que as professoras começassem a frequentar e visitar esses locais. Três professores declararam não possuir esse hábito e, uma das entrevistadas, declarou que outros eventos culturais são preteridos aos museus, como o teatro, por exemplo.

Perissé (2014) esclarece que adorações e execrações são relativas, dependem da trajetória e das experiências estéticas de cada indivíduo. O julgamento estético que se tende a fazer é fruto das relações estabelecidas a partir das experiências com as manifestações artísticas e culturais. $O$ autor salienta que essa formação não é mera satisfação caprichosa do gosto ou busca do que agrada: envolve também a compreensão dos motivos que levam a não gostar de algo, ou seja, obter consciência dos critérios de escolha na constituição de si.

Nessa perspectiva, entende que a formação estética do professor implica fazer das várias e intensas experiências a constituição de si, do modo de olhar a realidade, de aprender e de ensinar. Isso requer atividades que, extrapolando a leitura teórica, despertem a sensibilidade para a arte e tudo o mais, que permitam ao professor ir além do que pode enxergar no plano das coisas úteis e mensuráveis do cotidiano. Tenha ou não recebido formação estética na infância, Perissé (2014) explicita que é importante o professor também procurá-la intencionalmente, em um processo de autoformação que possibilite aperfeiçoar sua autoconsciência e se perceber como:

alguém chamado a ver na realidade externa: a beleza, o enigma, a sugestão, o símbolo, a sutileza, o risível, a ambiguidade, o sublime, o trágico...tudo aquilo que prima pela ausência em tantos exames, provas e testes decisivos para definir 0 destino acadêmico e profissional de nossas crianças e jovens (PERISSÉ, 2013, p. 53).

O autor adverte que não existe uma formação cultural e estética perfeita, capaz de fazer com que o professor se desenvolva completamente em todas as direções. No processo de formação, influenciam as inclinações, as escolhas, as oportunidades e as limitações. O importante é o desencadeamento do processo de percepção, de imaginação, de interpretação e de fruição estética.

Nesse processo, as qualidades das manifestações artísticas e culturais inspiram e contribuem para formar o professor. E, como consequência, o professor indica caminhos e possibilita condições, em sua prática, para que seus alunos também possam desfrutar das experiências estéticas em meio à cultura. São essas experiências, impregnadas de valor, que influenciam a sensibilidade do aluno que, por sua vez, é incentivado a atuar e se perceber enquanto sujeito 
criativo, histórico e culturalmente. Desta forma, Perissé (2003) considera que a ampliação da sensibilidade - da formação estética - designa uma exigência da profissão docente como modo concreto de responder aos desafios pedagógicos contemporâneos, além de contribuir para a busca do sentido mais amplo da educação - a formação humana.

Quando questionados se, na formação docente, houve algum estímulo para frequentar esses espaços, doze professores entrevistados afirmaram que receberam incentivos. Dentre esses, cinco declararam que foram incentivados a essa prática no ensino médio (curso de magistério) e na graduação, em diversas disciplinas. Três professoras relataram que esse estímulo decorria das disciplinas de "atividade complementar" e "estágio". E duas professoras destacaram, ainda, que mesmo recebendo o incentivo às práticas culturais durante a formação, havia dificuldades devido à falta de mobilidade pela cidade e por dificuldades financeiras.

Apenas duas professoras informaram não ter o incentivo de atrelar a prática docente na Educação Infantil com visitas a museus e centros culturais durante sua formação. Uma professora chegou a relatar que o maior incentivo à apropriação dos espaços culturais se deu apenas no trabalho e no curso normal.

Houve pela escola que eu vim trabalhar, porque eu gosto muito de trabalhar com a arte, e a escola trabalha com isso, então estamos sempre indo. (...) Eu fiz normal e fiz faculdade de Pedagogia - na faculdade eu não tive tanto, tive mais no Ensino Normal (...). Quando eu fiz uma especialização para trabalhar com Educação Infantil aí sim tive um incentivo, só que tive mais nas escolas em que eu trabalhei (Entrevista - Professora Célia/ Casa da Ciência).

Köptcke (2003) aponta que a visita a museus é quase sempre praticada por professores que declaram visitar estas instituições em seu tempo livre. A experiência pessoal e o grau de intimidade com esta prática cultural incidem igualmente no modo de estabelecer objetivos, organizar e atuar em uma visita com seus alunos. Coadunando com a perspectiva apresentada pela autora, os dados obtidos em campo também apontaram que a maioria dos professores entrevistados possuí esse hábito cultural.

Alguns fatores foram elencados como obstáculos dessa prática, como a falta de tempo, dificuldades financeiras e de locomoção pela cidade. Nesse aspecto, assim como apresentado no subcapítulo 2.3.1 "público infantil e a democratização dos museus", é novamente evidenciada a desigual distribuição dos equipamentos culturais na cidade.

A maioria dos professores também informou que houve incentivo na formação docente para as práticas culturais com turmas de E.I, principalmente nas disciplinas de estágio e atividades culturais. Contudo cabe questionar se esse 
incentivo foi acompanhado de uma reflexão acerca das possibilidades de formação cultural crítica nos espaços de cultura ou se ainda é adotada uma conduta de prática conteudista diante da pluralidade de manifestações artísticas e culturais.

Kramer (2000) considera que a formação cultural dos professores é um dos desafios urgentes para uma Educação Infantil de qualidade que seja, de fato direito de todos. Analisa que essa formação deve ser entendida como qualificação para a melhoria da qualidade do trabalho pedagógico, seja inicial (em escolas de formação de magistério e na universidade), e que tenha caráter permanente, promovendo a atualização de novas propostas pedagógicas e garantindo espaço para a pluralidade. A autora entende que pluralidade da formação cultural docente é fundamental e deve se constituir na oportunidade para que os professores possam discutir valores, preconceitos, experiências e a própria história, refletir sobre práticas e trajetórias vividas, compreender a própria história, redimensionar o passado e o presente, ampliar o saber e o saber fazer.

Diante das reflexões apontadas na literatura acerca da importância da formação cultural e estética do professor e, tendo a oportunidade de entrevistar e observar os professores de E.I com suas turmas nos museus selecionados para a pesquisa, busquei investigar como esses sujeitos declaravam perceber a relação entre as crianças da E.I e as instituições culturais - por que e com qual intuito adotavam essa prática?

\subsection{2.}

\section{A percepção dos professores sobre a relação entre museus e crianças}

Buscando conhecer a percepção que os professores possuem acerca da relação entre museus e crianças, foi possível averiguar que, dos quatorze professores entrevistados, nove possuem o hábito de visitar museus e centros culturais, frequentemente, com suas turmas de E.I. Quase todas as professoras das escolas particulares declararam essa prática: apenas uma revelou que não, porque, até então, só havia trabalhado com crianças do berçário. Dos professores das escolas públicas, cinco afirmaram levar suas turmas aos museus com a ressalva de que essa prática só era possível quando havia disponibilidade de ônibus. Quatro declararam não adotar essa prática (quase todas essas escolas visitavam um museu pela primeira vez), devido à dificuldade de conseguir transporte, a falta de recursos financeiros e a burocracia para que as Secretarias Municipais de Educação viabilizem a atividade. 
É primeira vez que venho (...). Antes eu trabalhava com criança do berçário, mas eram crianças muito pequenas. É a primeira vez que eu trabalho com um grupo um pouco maior. (Entrevista - Professora Jane/ Museu de Arte do Rio)

$\mathrm{Na}$ verdade, eu não costumo muito [frequentar museus com a turma de E.I] por questões financeiras do município. O município não nos oferece verba suficiente para elaborar projetos e para estar sempre levando. E, sempre que levamos, tem que ser por meio de projetos e muitas coisas - tem muita burocracia. (Entrevista Professora Gisele / Museu de Arte do Rio)

$\mathrm{Na}$ fala dessas professoras dois aspectos chamam a atenção: o primeiro é a concepção de que crianças pequenas, ou bebês, não se relacionam com os espaços culturais. Algumas especificidades com relação ao trabalho que pode ser desenvolvido com bebês nos museus já foram abordadas no subcapítulo 3.2 "Quando os pequenos cariocas visitam os museus e centros culturais da cidade", e não retomarei aqui a discussão. Entretanto, a fala da professora demonstra que a incompreensão quanto ao direito de acesso aos bens culturais e a importância da apropriação cultural no desenvolvimento infantil desde a mais tenra idade não parte apenas dos museus - um professor também pode ter essa compreensão. O segundo aspecto é o fato de as próprias Secretarias de Educação compreenderem que as visitas aos espaços culturais devem estar necessariamente atreladas aos projetos e aos conteúdos curriculares. Essa perspectiva deixa de considerar tantas outras possibilidades de apropriação estética e cultural que podem ocorrer nesses espaços, para além do que se restringe aos conteúdos curriculares.

Dentre as nove professoras que possuem a prática de frequentar instituições culturais com suas turmas de E.I, seis consideram que a visita a esses espaços é importante devido à experiência cultural proporcionada, à ampliação dos conhecimentos relacionados à arte, história e sociedade. Três professoras, assim como Secretarias Municipais de Educação, consideram que a importância dessa prática reside na complementação de conteúdo dos projetos escolares.

Sempre que eu tenho a oportunidade de acompanhá-los eu vou porque é uma forma de interagir as crianças à sociedade e ao conhecimento - o conhecimento básico do porquê das coisas, dos fatos, da história (Entrevista - Professora Maria/ Museu de Arte do Rio).

Eu acho importante eles vivenciaram o que nós trabalhamos na escola - porque nós levamos a arte para a escola - e aqui as coisas estão no museu (Entrevista Professora Liliane / Casa da Ciência).

No Museu Casa de Rui Barbosa, quando questionado o motivo da visita, foi revelado um projeto sobre literatura que a escola (pública federal) desenvolvia naquele ano (2017). As educadoras do Museu também declararam, em entrevista, que a procura dos professores de Educação Infantil pelo espaço, geralmente, advém mais do interesse pela biblioteca e pelo jardim do que pelo conteúdo do 
Museu. Os agendamentos de E.I têm como atrativo a contação de história que é oferecida no local e, posteriormente, quando fazem a visitação pelo Museu Casa, os professores estabelecem relações de maior identificação com o espaço museal.

Esse ano estamos falando sobre literatura - o modo como a literatura encanta e o que ela nos traz - junto com os conteúdos programáticos daquela faixa etária. Então por que não visitar a Casa de Rui Barbosa? Sempre tentamos linkar o projeto há alguma atividade externa e os museus também estão dentro disso (Entrevista Professora Leona / Museu Casa de Rui Barbosa).

$\mathrm{Na}$ Casa da Ciência, todas as professoras (da rede privada) que visitaram a Instituição relataram que o principal motivo da visita foi o conteúdo da exposição estar atrelado aos projetos trabalhados nas escolas - natureza e arte. Uma professora destacou a importância de se conhecer as obras de Portinari devido à pertinência de suas pinturas ao universo infantil - como as brincadeiras e suas formas de expressão sobre o meio ambiente.

Eu acho que a importância da arte de Portinari e a questão da visão dele com o meio ambiente, as brincadeiras infantis - porque tem tudo a ver com a faixa etária com a qual eu trabalho e o meio ambiente - projeto que estamos trabalhando na escola (Entrevista - Professora Liliane / Casa da Ciência).

Já no Museu de Arte do Rio, apenas uma professora (única escola particular observada na Instituição) atrelou o motivo da visita ao conteúdo programático trabalhado na escola e duas professoras informaram que a direção escolar é quem estipulava as visitas. Outros professores mencionaram motivos diversos para visitar o museu com as crianças, como: a disponibilização do ônibus pelo projeto "Partiu MAR", as atividades específicas do museu desenvolvidas para o público de Educação Infantil, a possibilidade proporcionar outras experiências culturais, dar oportunidades para que as crianças frequentassem outros espaços fora de sua escola/comunidade etc.

\begin{abstract}
Além de ter essas possibilidades que eu falei [o museu disponibilizou o ônibus], que normalmente não temos, amigos já haviam me dito da proximidade que permitia - o tipo de exposição que tinha aqui, essa interação maior com as crianças da faixa etária deles etc. Então eu já tinha essa recomendação (Entrevista - Professor Marcus/ Museu de Arte do Rio).
\end{abstract}

De modo geral, foi possível aferir, com os dados coletados nas entrevistas, que as quatro professoras de E.I da rede privada atrelavam a visita aos museus aos projetos escolares que estavam sendo desenvolvidos ao longo do ano. Os professores da rede pública, em sua maioria, elencaram como benefícios dessa relação proporcionar outras formas de a criança interagir com a sociedade, adquirir conhecimento sobre fatos históricos, promover contato com o meio cultural, aprender fora da sala de aula, ter contato com outras realidades além das comunidades onde vivem, dentre outros. 
Carvalho (2013) também constatou em sua pesquisa, ao abordar professores do segmento infantil que visitavam o espaço cultural investigado, que as escolas organizavam a ida aos equipamentos culturais de acordo com a temática abordada em seus projetos. Diante desse fato, a autora questiona se os profissionais da Educação Infantil não têm esvaziado a potencialidade dos museus e subestimado a capacidade das crianças:

Será que esses espaços não têm sido buscados apenas para suprir uma "lógica" curricular de realização de projetos que se configura como prática na Educação Infantil? Ou seja, será que a concepção de projetos (que em sua origem é muito boa) que têm norteado a prática na Educação Infantil não tem se configurado como amarras de práticas docentes, esvaziado a potencialidade dos espaços e servido de complemento à escola? (Carvalho, 2013, p.17).

Nesse sentido, é importante destacar que ainda existe uma incompreensão que o aspecto educativo dos museus - que, assim como as escolas, organizam as visões de mundo sobre aspectos científicos, artísticos, históricos - difere das especificidades da escola (LOPES, 1990; MARANDINO, 2001). Marandino (2001) esclarece que, apesar dos conceitos apresentados em muitas exposições terem relação com as temáticas escolares, o museu não organiza, necessariamente, seus conteúdos a partir do currículo do sistema formal de ensino. Em linhas gerais, pode-se dizer que os museus trabalham com saberes de referência tanto quanto a escola, porém, a organização desses saberes ocorre de acordo com as especificidades do trabalho museológico (e de pesquisa) de cada instituição, além de serem comunicados por meio de linguagens expositivas.

A partir dessa perspectiva, a autora considera que a discussão sobre atrelar ou não a visita ao museu ao programa das disciplinas (ou projetos) escolares é um dilema falso, pois o mais importante é a maneira pela qual a relação com o conhecimento é estabelecida. Esclarece que a escola não precisa abrir mão de seu currículo e deve articulá-lo, em diferentes níveis, com os conteúdos das exposições. Ressalta que esse não deve ser o objetivo final e único das visitas. A dimensão da ampliação da cultura e da educação pelo e para o patrimônio deve ser igualmente contemplada.

No que se refere à ampliação da dimensão educativa pelo patrimônio, nos três museus investigados, os professores entrevistados ressaltaram a relevância da experiência proporcionada às suas turmas. Os principais aspectos positivos elencados foram: a oportunidade de rever alguns conteúdos abordados anteriormente na escola, a ampliação do conhecimento de mundo, a descoberta de outros ambientes além dos que já estão habituados, a experiência museal, o enriquecimento cultural, o trabalho adequado dos mediadores, o contato com 
obras artísticas, as interpretações que as crianças conseguiram articular a partir do contato com o acervo, a interatividade e a dinâmica das propostas.

Uma visita sempre nos deixa marcas. As crianças que criam o hábito de visitar museus, não crescerão pensando que Museu é lugar de coisa velha e chata, e sempre nos enriquece culturalmente (Entrevista - Professora Ariane/ Museu de Arte do Rio).

Apenas uma professora que visitou a exposição "Aedes que mosquito é esse?", na Casa da Ciência, demonstrou uma compreensão de que o conteúdo daquela exposição não era relevante ou acessível ao entendimento das crianças.

Eu acho que eles são muito pequenos para esse tipo de exposição, eles não entendem. Você vê que os maiores se interessam mais. Eles ficam olhando sem entender muita coisa. Tanto que, de Educação Infantil, só vieram esses cinco, o resto são todos do Ensino Fundamental, porque os pais também não acham interessantes eles virem (Entrevista - Professora Célia/ Casa da Ciência).

Duas críticas ao trabalho realizado pelos museus nas visitas observadas foram destacadas pelos professores. No Museu de Arte do Rio, uma professora sentiu falta de que as crianças pudessem vivenciar melhor a exposição "Dja Guata Porã". E, na Casa da Ciência, apesar de considerar a visita relevante, como o grupo era composto por crianças de diferentes faixas-etárias, a professora considerou a visita um pouco cansativa para os menores.

A maioria dos professores (nove) afirmou que não havia preferência por algum tipo específico de museu para visitar com suas turmas. Foi mencionado que o principal fator para que a visita ocorresse seria a adaptação da linguagem por parte dos museus (acessível, mas não infantilizada) e uma proposta que atendesse as especificidades das crianças. Duas professoras consideravam que a visita à cada tipologia de museu depende, especificamente, do conteúdo que está sendo trabalhado nas escolas. Três professoras salientaram a correlação entre o público infantil e os museus de arte e ciência - por serem consideradas temáticas que atravessam o currículo da E.I e de fácil entendimento das crianças.

Eu acho que o mais chamativo para eles seria o museu de arte e museu de ciências, porque eles já estariam vendo o corpo humano, as fases do corpo humano - coisas que são trabalhadas dentro da escola são mais atrativas. Vão prender a atenção deles (Entrevista - Professora Maria/Museu de Arte do Rio)

Artes é um tema que atravessa a Educação Infantil. Acho que é um tema extremamente rico e de boa compreensão para as crianças (Entrevista - Professora Carla - Museu de Arte do Rio)

Sobre a ida a museus de temáticas que consideram "apropriadas" ou especificas da E.I, vale retomar os apontamentos de Benjamin (2017) sobre o "pedagogo bem intencionado", que seleciona o que julga ser de interesse da criança ou característicos da "natureza infantil", deixando de percebê-la enquanto 
sujeito que aprende e se apropria do mundo a partir das experiências que vive na cultura da sociedade na qual está inserida.

Oliveira (2011) salienta que, muitas vezes, surge a dúvida sobre como as crianças irão compreender determinados conteúdos dos museus se ainda são tão pequenas, ou mesmo, se o próprio professor não compreende. Nesse sentido, os estudos de Köptcke (2003) apontam que o maior ou menor domínio do conteúdo das exposições é um dos fatores determinantes da estratégia de visita privilegiada pelo professor. Esclarece que nenhum professor será capaz de dominar todos os assuntos presentes nas diversas exposições. Para a autora, é preciso desmistificar o espaço do museu possibilitando ao professor uma apropriação, onde conhecendo seu conteúdo e forma - percebendo o conteúdo expositivo enquanto elemento significativo para além da adequação aos currículos - possa se planejar e preparar seus alunos para uma visita.

Refletindo sobre essa seleção de saberes pertinentes à criança, Dewey (2002) aponta que, quando a criança entra na escola, várias disciplinas dividem e fracionam seu mundo que é fluído e fluente. Os assuntos são classificados, os fatos são arrancados do seu lugar original na experiência e organizados por referência a um princípio geral. Adverte que a classificação não é um aspecto da experiência infantil, pois as coisas não chegam compartimentadas ao indivíduo. As várias disciplinas, e seus conteúdos, são experiências que incorporam o resultado dos esforços e saberes da humanidade acumulados de geração em geração. Não devem ser apresentadas/tratadas como uma miscelânea de pedaços separados de experiência, mas de forma organizada e sistematizada, fruto de reflexão. Por isso, o autor considera que os fatos e os saberes contidos na experiência das crianças e aqueles contidos nos conteúdos de estudo das escolas devem estar entrelaçados. Ressalta que é preciso deixar de pensar a experiência em meio à cultura como algo difícil ou além da capacidade da criança. Os assuntos da ciência, da história e da arte servem para revelar o mundo à criança.

Os museus, por sua vez, são lugares que guardam os saberes acumulados pela humanidade ao longo das gerações, e comunicam por meio de uma linguagem expositiva que busca a sensibilidade e o estímulo ao interesse para com seus assuntos. Sob essa perspectiva, qualquer assunto dos museus pode ser passível de entendimento da criança que, a partir de suas experiências, pode refletir sobre o que vê e vive como sujeito histórico cultural que é.

Para promover uma formação alicerçada nessa perspectiva de valorização das experiências da cultura, Dewey (2002) ressalta a necessidade de que o 
professor tenha completa noção que a realidade envolvida nos conteúdos curriculares advém da experiência acumulada pela humanidade, que produziu os saberes organizados e selecionados por disciplinas ou áreas do conhecimento. Caso contrário, desconhecerá a capacidade e as formas de concretizar uma educação que não se desvincule da experiência. No que se refere à especificidade de desenvolvimento dessa perspectiva educacional desde a infância, o autor pontua que é fundamental reconhecer, afirmar e valorizar a capacidade da criança de atuar em meio à cultura.

Refletindo sobre essa capacidade de atuação da criança perante o mundo, e também nos museus, Fallon e Chavepeyer (2013) destacam que os artistas, ao longo do processo de criação, buscam e experimentam ferramentas e formas de aperfeiçoar seu modo de comunicação. A criança, quando visita o museu, também está em seu "laboratório". E, com um trabalho de mediação adequado, poderá experimentar diferentes realidades que usarão pouco a pouco para se comunicar.

Ao descobrir esse terreno comum entre artistas e crianças, os profissionais da primeira infância contemplam sua representação da arte de uma maneira diferente. Não se trata mais de estar interessado em trabalhos em termos de "é bonito / não é bonito" ou "é para crianças / não é para crianças", ou para fazer julgamentos sobre seus gostos pessoais, mas para se interessar pelos processos dos artistas da mesma forma que estão interessados nos processos dos pequenos que exploram o mundo. (FALLON e CHAVEPEYER, 2013, p. 13)

Dewey (2002) também destaca o papel do professor - que possui a experiência sistematizada e definida da mente adulta - como sujeito que deve garantir a base de orientação da criança no seu processo de construção de conhecimento em meio às experiências. Considera que a participação do professor não deve ser interpretada como imposição externa, pois consiste em orientar as experiências no sentido de uma realização mais adequada, fornecendo as condições necessárias para que os impulsos das crianças sejam vistos de forma desejável e utilizados na conquista de novas experiências, aspecto reiterado por Vigotski (2009). No que se refere às práticas educativas, considera que deve haver um trabalho contínuo do professor de inventar e planejar, a cada dia, a viabilização, de maneira efetiva, do acesso das crianças ao conhecimento produzido e sua participação na produção histórica e cultural (VIGOTSKI, 2009).

\subsection{3.}

\section{As relações estabelecidas pelos professores no momento da visita}

Após obter, por meio de entrevistas, informações sobre o hábito cultural dos professores, sobre o incentivo para se adotar práticas culturais durante a formação e saber as impressões acerca da relação entre E.I e museus, apresento o que foi possível observar da relação estabelecida por esses professores com as 
temáticas da exposição, com os mediadores e com as crianças. De modo geral, foi possível constatar, nos três museus investigados, três relações distintas.

O primeiro grupo tinha como característica grande interesse pelo conteúdo das exposições e participavam ativamente da mediação com as crianças e com os educadores dos museus. Apesar da constante observação e cuidado com as crianças, esses professores, mesmo próximos ao grupo, aproveitavam para ver outros aspectos da exposição que não eram foco de atenção das crianças ou dos mediadores. As formas de estímulo ao envolvimento das crianças com as exposições eram variadas: perguntavam sobre as impressões, apontavam curiosidades, compartilhavam conhecimentos, relembravam experiências anteriores, instigavam o faz-de-conta, a surpresa e tornavam a linguagem dos mediadores mais acessível para as crianças.

Criança: Por que ele só pinta coisa ruim? [referindo-se aos quadros de Portinari] Professora: Emília, ele pintava essas coisas porque faz parte, ele pintava certas coisas para as pessoas ajudarem os retirantes. E pintava essas coisas para preservar a natureza, ele pintava como uma forma de alerta! [tentando levar o grupo à reflexão sobre o caráter ético e estético da arte] (Caderno de Campo - Casa da Ciência).

Mediador: Vocês conseguem ver o que é diferente? Qual a diferença de uma floresta para a outra? [observando dois quadros de Portinari]

Crianças: Tem tucano/ Porque aqui ela não tem areia [quadro floresta amazônica] e essa aqui tem [quadro floresta tropical] / Aquela não tem bambu.

Professora: O que diferencia uma floresta da outra?

Crianças: As cores / os animais.

Mediador: Isso! As cores delas são diferentes, estão vendo?

Criança: Vermelho.

Professora: Isso! Eu lembro de sol, de calor.

Mediador: A floresta amazônica tem muitas árvores juntas, muito diferentes e aí forma esse ambiente um pouquinho mais escuro que o Portinari tentou retratar.

Professora: Quase não entra luz porque são tantas e tantas árvores juntinhas, uma da outra, que o sol não consegue quase entrar no chão e por isso que vemos a diferença da cor. Já a floresta tropical é assim como o Rio de Janeiro - vemos o sol em todo lugar por isso fica assim, mais claro. (Caderno de Campo - Casa da Ciência)

O segundo grupo, representado pela maior parte dos professores, apesar de demonstrar interesse pelo acervo e conteúdo das exposições, permanecia sempre ao lado das crianças e do mediador. Era comum que os docentes adotassem uma postura de visitante junto à turma. Ficavam sempre por perto, demonstravam atenção e interesse na mediação, ajudavam a controlar impulsos do grupo para mexer nas peças do acervo e estimulavam as crianças a prestar atenção e a interagir com o mediador. As formas de controle adotadas pelos professores sobre o grupo consistiam em chamar a atenção sobre o comportamento das crianças, coordenar como deveriam se locomover pelo espaço, coibir o impulso de avançar sobre o acervo e, até mesmo, cercear a livre 
expressão sobre o entendimento que as crianças articulavam sobre a temática das exposições. Frases como "vamos devagar", "não mexe", "vamos prestar atenção no que ele [mediador] está falando" eram recorrentes.

Professora: Ai eu adoro Portinari! Eu amo! E eu quero ver. Vamos parar de falar um pouco, se não, não vamos conseguir ver nada! Na escola vocês falam mais. (Caderno de Campo - Casa da Ciência)

Já o terceiro grupo identificado era composto por professores que se isentavam de participar da visita e de colaborar com os mediadores. Não demonstravam muito interesse pelo conteúdo das exposições, apenas cuidavam para que nenhuma criança saísse do espaço. Sobre esse grupo é importante questionar qual o envolvimento dos professores com a ação de levar as crianças aos museus. São os professores da turma ou estão auxiliando diferentes grupos da escola em razão da quantidade de responsáveis? Conhecem o Museu e sua proposta? Foram inseridos pela direção no contexto/objetivos da visita? Questões como essas podem influenciar diretamente no grau de envolvimento do professor na forma como interage com o conteúdo expositivo, com os mediadores e com as crianças.

Em diversos momentos as professoras demonstram querer se ausentar da responsabilidade pelas crianças, deixando o grupo sob cuidado do mediador. Exemplo 1: Crianças e mediador caminham no divisor (grande tecido azul) observando algumas maquetes com a arquitetura do museu e as professoras ficam sentadas. A diretora fala para professoras "Vocês vão ficar sentadas aí? Nós vamos entrar no museu". Nesse momento, as professoras se levantam para acompanhar a turma. Exemplo 2: As crianças conversam com o mediador sobre os elementos da paisagem que observam do terraço, as professoras ficam tirando selfies e deixam a turma sozinha com o mediador enquanto a diretora registra o momento com fotografias do grupo. Exemplo 3: Após a realização de uma atividade, os mediadores não tiveram ajuda dos professores para ajudar as crianças a calçarem novamente os sapatos (Caderno de Campo - Museu de Arte do Rio)

É importante ressaltar que, no que tange à relação estabelecida pelos professores com as crianças no momento de visita aos museus investigados, duas formas de relacionamento foram evidenciadas - estímulo e controle. Embora dicotômicos, os comportamentos eram passíveis de serem observados em uma única visita, na atitude dos três grupos supracitados. Ou seja, os mesmos professores que, por vezes, buscavam estimular e ampliar a experiência das crianças junto aos mediadores e aos espaços expositivos, em outros momentos buscavam de forma rigorosa manter o controle sobre o grupo.

Alguns estudos que se propõem a discutir a relação entre museus e escolas apontam essa forte impressão de apagamento da atuação docente e do deslocamento do papel de professor que costuma se colocar em posição de visitante, assim como as crianças - o que veem e experimentam parece ser novidade e não atuam ou oferecem auxílio aos profissionais do museu na tarefa 
de mediação. De modo geral, durante a visita o professor fica de fora, tornandose observador passivo e consumidor de produtos prontos que nem sempre correspondem a seus objetivos para a visita. Frequentemente, essa postura indica que a ida ao museu não foi preparada e, para o professor, se aproxima mais de uma atividade de lazer ou de entretenimento do que a possibilidade de uma experiência de cultura e de educação reflexiva (CARVALHO e PORTO, 2013; MOURA, 2011; KÖPTCKE, 2003).

Oliveira (2011) compreende que essa postura de "apagamento" docente pode ser explicada devido à preocupação dos professores com seus próprios limites de formação cultural, artística e pedagógica, no que se refere a ajudar as crianças a responder algumas inquietações que podem surgir no contato com o conteúdo dos museus. Optam por deixar a tarefa de mediação entre os saberes das crianças e os saberes do museu a cargo de seus profissionais, que são vistos como especialistas que dominam o conteúdo em exposição. Köptcke (2003) alerta que essa estratégia acarreta problemas, pois é comum que os professores se sintam excluídos do processo de concepção das atividades, avaliem que a linguagem utilizada nem sempre é adequada ou que a abordagem privilegiada pelos mediadores não se interessa pelas experiências e expectativas do grupo visitante.

Nesse sentido, Carvalho e Porto (2013) ressaltam que não se pode, simplesmente, culpar os professores por não aproveitarem totalmente a potencialidade dos espaços culturais em sua prática. Consideram que deve ser assumida uma responsabilidade política desde a mais tenra idade que assegure e estimule o direito à arte e à cultura. Moura (2011) corrobora com a perspectiva apontada pelas autoras e destaca que pensar na formação cultural das crianças implica pensar, necessariamente, na formação cultural de seus educadores. É preciso prover uma formação cultural dos professores que tenha qualidade, que se relacione com uma apropriação crítica e reflexiva sobre os museus e demais espaços culturais.

Refletindo acerca dos programas de formação nos museus destinados aos professores, Kramer (1998) considera que estas iniciativas precisam ter seu potencial expandido criticamente para além de treinamentos formais. Não se trata de supervalorizar os museus, espaços e acervo, mas de levantar perguntas para promover uma experiência cultural crítica de formação. Nesse sentido, Moura (2011) reitera que, em uma perspectiva de formação cultural, reconhecer a importância da experiência coletiva significa perceber o papel fundamental dos diferentes sujeitos na interação social para a construção do conhecimento. 
Portanto, é importante que o professor seja concebido enquanto um dos agentes fundamentais da experiência educativa que contribui para que o grupo construa significados coletivos e compartilhe seus aprendizados nos museus.

Para além dos programas de formação, Fallon e Chavepeyer (2013) elencam, ainda, outras estratégias que podem contribuir para estreitar laços com os professores que visitam museus com crianças pequenas, como adotar posturas acolhedoras, propiciar uma sensação de segurança e bem-estar durante a realização das atividades, promover uma relação respeitosa de interesse compartilhado através do trabalho dos setores educativos, dentre outras.

\section{4.}

\section{Articulações entre museus e educação infantil}

Analisando, historicamente, a relação entre os museus e as escolas, no Brasil, Lopes (1991) esclarece que foi na década de 1920, com as ideias da "Escola Nova"65, que essa relação passou a se estreitar. O movimento que primava por mudanças nas teorias educacionais e buscava atrair novos modelos educacionais, outorgava que a aprendizagem ocorria de modo mais efetivo em ambientes motivadores, com diversidade de materiais didáticos capaz de estimular as aptidões e os interesses pessoais. Nesse contexto educacional, foram sendo ampliadas as ideias do uso educacional dos museus como espaços profícuos para esse tipo de ensino e aprendizagem. A autora salienta que essa origem do papel pedagógico dos museus, embora tenha possibilitado uma aproximação com as escolas, contribuiu também para que sua dimensão educativa fosse reduzida à complementação do ensino escolar. Inseridos nesse contexto, de completar os conhecimentos atribuídos pela escola, considera que os museus abrem mão de se colocar como instituições culturais, propiciando ao público outras maneiras de desvendar e compreender o mundo.

Marandino (2001) acredita que, atualmente, é possível uma articulação entre as duas perspectivas em jogo: a escola não precisa abdicar de seus objetivos ao visitar tais espaços, nem os museus precisam deixar de ter como foco a ampliação da formação cultural para o público escolar. Köptcke (2003) coaduna com a perspectiva ao afirmar que a parceira a ser estabelecida entre museus e

65 O movimento da Escola Nova surge no final do século XIX, mas é implementado no Brasil no século XX. Seus princípios foram expostos no Manifesto dos Pioneiros da Educação, publicado em 1932. A crescente industrialização da sociedade, com rápidas transformações, demandou a ampliação da rede escolar, bem como uma escola que preparasse para o novo. Mantendo as ideais do liberalismo brasileiro, propôs novos caminhos à educação, representando o esforço de superação dos valores e dogmas tradicionais. Fonte: <https://www.portaleducacao.com.br/conteudo/artigos $>$. Acesso em: 18 out. 2018. 
escolas deve ter como objetivo oferecer aos estudantes, além da aquisição de conhecimentos, o desenvolvimento de uma atitude positiva em relação à cultura, ao patrimônio e às instituições culturais, desenvolvendo uma apropriação crítica desses espaços.

Diversos estudos apontam a relação profícua que pode ser estabelecida a partir de uma articulação entre as instituições museais e escolares com o intuito de contribuir para a melhoria do trabalho educativo desenvolvido com o público escolar (MOURA, 2011; CAZELLI e COIMBRA, 2007; CARVALHO, 2016; KÖPTCHE, 2003, SHAFRON, 2015, FALLON e CHAVEPEYER, 2013). Sobre a atuação dos educadores que participam diretamente dessa relação, Kramer e Carvalho (2012) salientam que é função do professor agir de forma a possibilitar formação cultural no sentido de promover experiências que favoreçam práticas interessantes com os alunos. E, quanto aos profissionais do museu, consideram que é parte de seu processo educativo a construção da cidadania, pois a formação cultural é direito de todos - crianças, jovens e adultos são indivíduos sociais, sujeitos históricos e cidadãos.

Köptcke (2003) avalia que embora a relação entre museus e escolas seja percebida como um projeto que possui objetivos em comum (educar, diversificar o acesso à cultura, socializar etc.), alguns obstáculos se apresentam de forma contundente.

Ao me propor a investigar a relação específica entre Educação Infantil e os museus, junto aos seus principais agentes - crianças e educadores (da escola e do museu) - foi preciso buscar conhecer os principais aspectos que articulam e dificultam essa relação. Como se dá, efetivamente, a articulação entre museus e Educação Infantil? Quais os obstáculos enfrentados pela escola e pelo museu? O que se sugere para a melhoria dessa relação? Quais ações podem contribuir para essa articulação?

\subsection{1.}

\section{Obstáculos na relação entre museus e educação infantil}

Quando questionados se consideravam que havia dificuldade na relação entre museus e Educação Infantil, o principal aspecto apontado pelos professores desse segmento foi identificar instituições que oferecessem um trabalho adequado às especificidades do público infantil. Outros fatores também foram mencionados, como o excesso de burocracia, a dificuldade em providenciar o transporte (na rede pública), o tempo enxuto devido à grade de conteúdos curriculares e o forte contexto de violência urbana na cidade do Rio de Janeiro. 
O preconceito de acharem ainda que a Educação Infantil não consegue ir para museu, que a Educação Infantil tem que ir para zoológico, parquinho, Quinta da Boa Vista e circo. Todo mundo acha que com a Educação Infantil é só isso, mas agora alguns museus estão começando a abrir as portas (...). Quando falamos que a turma é de 3 anos de idade, eles falam: "Ah, mas não temos exposição para isso!", mesmo o professor conseguindo adaptar qualquer exposição para a Educação Infantil (Entrevista - Professora Ariane/Museu de Arte do Rio).

No que se refere à noção de um trabalho educativo adequado, Köptcke (2003) destaca que, na articulação entre museus e escolas, ocorre um confronto entre as diferenças das culturas profissionais. Segundo a autora, as culturas profissionais resultam de um processo contínuo, (iniciado na graduação/formação inicial) onde se define a natureza do conhecimento e das competências pertinentes a uma dada atividade, desenvolvidas no exercício da profissão. $E$ nesse processo são assimiladas práticas, valores e condutas percebidas como "naturais" a um determinado campo de atuação profissional. Ou seja, professores, artistas, cientistas, mediadores, curadores e museólogos podem não compartilhar de uma visão semelhante acerca do que é "natural" no trabalho educativo com grupos escolares no museu, principalmente quando o grupo é constituído por crianças. Na fala dos mediadores entrevistados foi possível aferir que a formação inicial é repleta de lacunas no que se refere ao entendimento sobre a infância, práticas com Educação Infantil e a reflexão sobre a educação que ocorre fora dos espaços escolares.

Os educadores do museu também julgam que o trabalho desenvolvido com as crianças poderia ser mais adequado ou melhor desenvolvido e apontaram como algumas de suas dificuldades na recepção ao público infantil: a estrutura rígida dos espaços que gera entraves para o desenvolvimento de atividades mais dinâmicas; a dificuldade por vezes encontrada no momento de adaptar a linguagem de forma a tornar os conhecimentos da exposição interessantes e acessíveis; e a falta de estrutura (fraldários, estacionamento próximo etc.).

Acho que é uma dificuldade de toda instituição. Historicamente, os museus não são lugar para crianças, não são pensados para serem espaços para criança, não é um lugar que você pode - a princípio - correr, não pode tocar nas coisas. Tem toda uma parte de conservação que, às vezes, pode ser uma dificuldade, mas temos uma bandeira que "museu é lugar de criança pequena!" e vamos tencionando isso. À medida em que as crianças são praticantes do museu, vão forjando esses espaços que não existiam, até então, para elas (Entrevista - Clarisse/Educadora de Projetos do Museu de Arte do Rio).

Lopes (1991) reitera que a separação entre especialistas de áreas de conhecimentos específicos e os responsáveis pelas ações educativas nos museus é alvo de constante conflito. A equipe educativa, geralmente composta por licenciados, costuma atuar de modo desvinculado dos pesquisadores. Os 
pesquisadores, por sua vez, mesmo trabalhando em museus, não dão prioridade às atividades de divulgação de seus trabalhos para o público leigo ou escolar.

Além dos fatores supracitados que dificultam o trabalho, foram mencionadas diversas "dificuldades operacionais" enfrentadas na relação com as escolas, como atrasos dos grupos, horário para lanche, necessidade de ir ao banheiro e parar toda a visita, número excedente de crianças para além do agendado, falta de informação sobre o grupo para o planejamento das atividades, dentre outras.

Se pararmos para pensar, de maneira fisiológica, todos sentirmos fome e vontade de ir ao banheiro - não é esse o problema! Ás vezes, são situações contornáveis pelos professores e pela equipe escolar só que resolvem deixar na nossa mão [referindo-se ao tempo de visita restrito que ainda é reduzido quando as escolas chegam atrasadas e querem lanchar primeiro] (Entrevista - Enzo/Mediador do Museu de Arte do Rio).

Uma dificuldade, que foi a primeira coisa que eu senti, é que, às vezes, as turmas são muito grandes (...). Quando tem excedente de crianças fico um pouco tensa porque não estou dando atenção para todo mundo (...). Ficamos em uma sinuca de bico, porque é claro que queremos atender ao maior número de turmas, mas se deixamos entrar mais de 30 fica aquela confusão! (Entrevista - Maria Luiza/Mediadora Museu Casa de Rui Barbosa)

Os museus de História e de Ciência investigados pontuaram a resistência e a incompreensão que as escolas e professores de E.I apresentam no que se refere à capacidade de apropriação de seus conteúdos pelas crianças. Já no museu de Arte foi mencionado o fato de as escolas agendarem visitas de E.I para fins de puro lazer, ou buscando unicamente um diálogo com o currículo, não percebendo, portanto, esses locais como espaço de construção de conhecimento, uma outra oportunidade, um outro momento etc.

Talvez as escolas de Educação Infantil tenham uma resistência maior com alguns assuntos específicos nossos. Algumas [escolas] acham que não é tão apropriada a linguagem por ser mais científica e, na verdade, isso não existe. A nossa proposta é para diversos tipos de público (Entrevista - Paula/ chefe da Seção de Educação da Casa da Ciência)

Os professores de Educação Infantil não têm tanto o hábito de visitar o nosso Museu porque acham que acaba sendo mais facilmente apropriado por um público que já é leitor (...). Quando eles agendam, claramente, fica perceptível que dentre esses três espaços [museu, jardim, biblioteca], fazer só uma visita rápida ao Museu já está bom (Entrevista - Francisca/Museóloga do Museu Casa de Rui Barbosa)

Percebo que muitas vezes eles [professores] estão buscando mais um diálogo com o currículo, ou seja, com que está sendo tratado na sala de aula do que um outro espaço de construção de conhecimento, uma outra oportunidade, um outro momento etc. Muitas vezes, o agendamento do público infantil aqui é visto dessa forma ou só como lazer, uma data que inaugurou as férias (Entrevista Maximiliano/Mediador do Museu de Arte do Rio).

Essa perspectiva de incompreensão acerca dos propósitos e possibilidades a serem estabelecidas com os museus, por parte dos professores, revela uma falta de articulação entre as instituições museais e as escolas durante o agendamento e os momentos anteriores à visita. Nesse sentido, Moura (2011) 
alerta que quando as escolas não estabelecem relação com a atividade, muitas vezes, os professores conhecem o museu junto com as crianças. Sem ter clareza do que vão fazer, ver e ouvir é difícil que a escola se comprometa com atividades (preparação, acompanhamento, desdobramentos) que promovam a ampliação das experiências das crianças. Para a autora, nessas situações a visita ao museu ocupa mais o lugar de entretenimento do que o de cultura e educação e o museu é procurado como um ponto turístico, sem que a relevância de sua dimensão educativa seja reconhecida.

Ainda sobre esse aspecto, a relação estabelecida com os professores de E.I foi uma das maiores dificuldades apontada pelos mediadores dos três museus investigados. Consideram que os professores interferem "negativamente" na ação educativa que está sendo desenvolvida quando se eximem da responsabilidade pelo grupo, realizam intervenções drásticas e duras para o controle do comportamento das crianças ou insistem para que o grupo não seja dividido no momento da visita. Nesses momentos, os mediadores relataram que não sabem como agir e não se sentem à vontade/com autoridade para intervir e orientar os professores a agirem de outra forma.

Não é em todos os casos, mas acontece de os professores quererem não só fazer fila pelo museu, mas também separar por gênero. Aí é demais! Tento fazer o professor se reconhecer como público, porque ele entra no museu com o baluarte da autoridade e não larga (...). Com grupos de crianças eles evitam ficar relaxados porque têm que olhar as crianças e envolve mais cuidado (Entrevista Abel/Mediador do Museu de Arte do Rio).

A primeira dificuldade é que, às vezes, os professores não entendem que separar a turma é importante. Não querem! Isso é complicado porque acaba que entro no problema de não conseguir dar atenção para todo mundo e aí dispersa. Fica uma fila enorme, não acho legal. Isso de fila, que os alunos têm que ir andando em fila, não gosto. Tem também o medo de algo quebrar e, às vezes, a intervenção é muito dura. Eu não sei como lidar, realmente! Porque você não vai brigar com o professor na frente do aluno, você não vai tirar a autoridade dele, não é sua função fazer isso (Entrevista - Maria Luiza/Mediadora do Museu Casa de Rui Barbosa)

Alguns professores acham muito que a responsabilidade é nossa. Da porta para frente a responsabilidade é nossa, então eles ficam "toma as crianças e se virem". Isso acaba desestimulando porque os alunos veem que se o professor dele está na porta, sem prestar atenção, por que ele vai prestar atenção? Dessa forma eles [as crianças] acabam não nos respeitando muito. É muito complicado quando vem esse tipo de professor, mas não são todos (Entrevista - Andrea/Mediadora da Casa da Ciência)

Sobre o controle rígido que se tenta impor nas visitas escolares, na década de 1990, Lopes (1991) já criticava as visitas mediadas com esse público caracterizadas com a presença do professor ou do mediador na frente e as crianças atrás, em fila dupla, de mãos dadas. Ou, quando as crianças não são muito "obedientes", o professor envergonhado ou o mediador irritado insistem em recomendações como "não-toque", "faça silêncio", "levanta a mão para falar". 
Embora essa tenha sido uma crítica dos mediadores aos professores, nas observações em campo, foi possível constatar que, algumas vezes (embora poucas), os mediadores também utilizavam essas estratégias, principalmente quando o grupo era grande.

Carvalho (2011) ressalta que não se pode culpabilizar a escola nem os profissionais que atuam nos museus pela falta de preparo no trabalho com qualquer que seja o público. Conforme foi possível constatar nas entrevistas, a autora também salienta que os cursos de formação ainda não conseguem promover, suficientemente, a discussão acerca da potencialidade dos espaços culturais.

Dentre todos os obstáculos, apontados pelos educadores da escola e do museu, foi mencionado, de forma recorrente, como os cortes de verba na área da cultura vêm afetando a potencialidade educativa dos espaços culturais. Isso se reflete, principalmente, na falta de transporte e de toda uma estrutura/logística (maior equipe, formação, materiais, divulgação etc.) necessária para o desenvolvimento de um trabalho adequado com as crianças de E.I e com os demais públicos.

Os estudos de Carvalho (2016) e Cazelli (2010) apontam que as escolas públicas, no período de realização das pesquisas - 2004 - apresentavam frequência mais elevada nos museus do que as escolas particulares. Ou seja, as escolas públicas assumiam um papel ativo e equalizador no acesso à cultura. Embora os professores revelassem que o transporte era a maior dificuldade para - acesso a instituições culturais (as escolas da rede particular também mencionaram essa dificuldade), vários relatos confirmavam que havia sempre "a figura de algum político responsável por conseguir o transporte para a escola (...) destacando que os benefícios passavam não apenas pelo transporte, mas também pela alimentação e por doações da mais variada ordem" (CARVALHO, 2016, p. 136).

Com as entrevistas realizadas em campo, no ano de 2017, foi possível constatar que a falta de transporte está deixando de ser uma dificuldade e se tornando um impeditivo para que os estudantes da rede pública tenham acesso às instituições culturais. A falta de transporte foi mencionada por todos os professores da rede pública, e também pelos profissionais dos museus. Das três instituições investigadas, a única que recebeu o público de E.I oriundo da rede municipal foi o Museu de Arte do Rio, no período em que conseguiram disponibilizar ônibus. Nenhuma das quatro professoras da rede privada de ensino mencionou essa dificuldade. 
Moura (2011) também constatou o número reduzido de escolas públicas na instituição onde realizou sua pesquisa. Destaca-se então a necessidade de o poder público gerar recursos e elaborar políticas públicas que viabilizem e incentivem o uso desses espaços, principalmente no que se refere às ações voltadas para a infância (CARVALHO, 2011; MOURA, 2011).

\subsection{2.}

\section{Mudanças necessárias para a melhoria da relação entre museus e educação infantil}

Nas entrevistas realizadas, algumas proposições feitas pelos educadores, apontam aspectos a serem aperfeiçoados para desenvolver melhor o trabalho junto ao público de Educação Infantil.

Alguns aspectos sinalizados consistem na necessidade de mudanças estruturais nos museus, como: maior estrutura para elaboração de materiais, estacionamento para os transportes coletivos escolares, mais tempo para o planejamento das atividades, participação das equipes educativas na concepção das exposições para maior articulação com as atividades educativas e o aproveitamento das áreas externas.

Adequações nos discursos e nos espaços expográficos também foram mencionadas pelos entrevistados enquanto aspectos que podem ser melhor trabalhados na Casa da Ciência e no Museu Casa de Rui Barbosa.

A atualização na formação dos mediadores e a troca de conhecimentos com setores educativos de outras instituições e com a Rede de Educadores em Museus (REM-RJ) foram necessidades amplamente destacadas pelos educadores do Museu de Arte do Rio. No Museu Casa de Rui Barbosa, foi citada também a formação interna dos demais funcionários (recepção e segurança) da Instituição para melhor receber o público infantil.

A efetivação de ações que busquem aproximar professores e mediadores foi apontada como um aspecto a ser desenvolvido dentro das três instituições. Apesar da relação atual com os professores ter sido sinalizada como uma dificuldade, os mediadores também salientaram a importância do auxílio dos professores no momento da mediação. Reconhecem que o professor é detentor de saberes e práticas que podem ser compartilhados e modificados para o melhor desencadeamento das visitas. Para tanto, ressaltam a importância de se obter um retorno com a avaliação dos professores quanto ao trabalho desenvolvido, aspecto pouco eficaz devido à falta de respostas críticas e sinceras.

Uma vez eu estava mediando uma visita em que comecei a falar, falar... e percebi que não ia conseguir chegar no que eu queria explicar - o que é o conhecimento indígena e como esse conhecimento indígena continua nos dias de hoje. Queria falar sobre isso para crianças de 5 anos e percebi que, para mim, não seria possível. 
Então eu falei "Professora, me ajuda? Deixo na sua mão!" e ela, calmamente, começou a explicar, a fazer a mediação comigo e eu a observar. (Entrevista - Abel / Mediador do Museu de Arte do Rio)

Uma vez, uma professora retornou por telefone para dizer que fez a visita e que não foi tão legal. Nessa conversa que tive pelo telefone com a professora pude entender que não foi bom até por minha culpa - porque quem atendeu foi um estagiário e na conversa que nós tivemos eu falei assim "Ah, não se preocupa muito em fazer uma visita longa porque é ruim para as crianças, elas ficam entediadas porque é uma faixa etária em que tudo como eles é em outro tempo. Elas ainda estão construindo essa maturidade de fixar e ficar prestando atenção em alguém!". Acabou que eu acho que foi muito rápida [a visita], mas foi legal esse retorno porque na medida em que conversamos novamente, as outras visitas passaram a ser maravilhosas. Infelizmente não temos muito esse hábito, de o professor dar um retorno para os museus (Entrevista -Francisca/Museóloga do Museu Casa de Rui Barbosa).

Moura (2011) considera que são necessárias diversas reformulações para que uma relação de parceria entre mediadores e professores seja estabelecida, e , por vezes, ultrapassam o alcance do próprio museu, como a implementação de políticas públicas de formação cultural dos professores e a valorização da formação cultural e estética nos currículos escolares. Acredita que há um espaço de ação e colaboração que pode ser ocupado pelos museus, principalmente no que tange às ações dirigidas aos professores. Ou seja, uma atenção especial aos educadores que visitam os museus com as crianças é necessária. A relação de parceria, entre ambos os profissionais, contribui para ajudar as crianças a se relacionarem com o museu e seu acervo de forma mais reflexiva e participativa.

Köptcke (2003) ressalta que essa relação será melhor estabelecida a partir da reconstrução de representações recíprocas (por parte dos professores e dos mediadores), orientando assim as ações de cada participante, e permitindo, pela negociação, equacionar os conflitos existentes.

\subsection{3}

Ações que contribuem para a articulação entre museus e escolas

Diante das constatações acerca dos obstáculos encontrados e das mudanças necessárias para a melhoria do trabalho a ser desenvolvido com o público infantil, foi possível elencar algumas ações a serem implementadas ou aperfeiçoadas pelos museus que também podem contribuir para a articulação entre essas instituições educativas: a divulgação das ações educativas; a difusão do conhecimento produzido no museu acerca das relações com o público infantil e a oferta de programas de formação/estudo para professores. Deste modo, busquei analisar se, e como, essas ações eram realizadas nos museus investigados. 


\section{a) Programas de formação para professores}

Sobre programas, cursos e encontros com professores organizados pelos museus para discutir o acervo, temática e os aspectos educativos, foi possível aferir que nenhuma das instituições investigadas possui tal ação destinada, especificamente, ao professor de Educação Infantil.

O Museu Casa de Rui Barbosa foi a única instituição que afirmou não desenvolver, há alguns anos, nenhum tipo de programa para professores em decorrência de uma equipe reduzida.

A Casa da Ciência promove oficinas sobre conteúdos relativos às exposições que são abertas ao público e podem ser realizadas especialmente para grupos de professores mediante solicitação. Vale destacar que, até a época de realização do trabalho de campo (ano de 2017), a Instituição não identificou nenhuma oficina solicitada por professores de E.I.

O Museu de Arte do Rio conta com o Programa de Formação de Professores que oferece cursos gratuitos, de diferentes temáticas, para professores de qualquer segmento. O Programa pode ser frequentado sem que o professor tenha a obrigatoriedade de visitar posteriormente o museu com suas turmas.

Atuamos no Programa pensando na formação do professor como sujeito, independente de ele estar vinculado a uma instituição de ensino - ele pode ser só um professor/um educador formado [sem estar atuando] e querer participar dos nossos cursos de formação. O Programa de Formação de Professores é frequentado por muitos graduandos também (Entrevista - Clarisse/Educadora de Projetos do Museu de Arte do Rio).

Já no projeto "Partiu Mar", do ano de 2017, pela primeira vez, a instituição vinculou como exigência para a realização da visita (e, conjuntamente, a disponibilização do ônibus) a participação dos professores em um curso de formação promovido pelo Museu. A Educadora de Projetos relatou que essa experiência gerou alguns ruídos, uma vez que a imersão na exposição promovida no curso era diferente da atividade desenvolvida quando voltavam ao museu com suas turmas. Salienta que foi uma experiência importante para que os professores conhecessem e compreendessem melhor o trabalho da Escola do Olhar e os diferentes eixos temáticos disponíveis para as atividades educativas com grupos escolares.

Refletindo sobre as experiências de formação destinadas aos professores, Köptcke (2003) considera que algumas podem ser favoráveis à articulação entre museus e escolas e outras não. Conforme mencionado no subcapítulo "4.3.3 as relações estabelecidas pelos professores no momento da visita", apenas transmitir informações aos professores sobre o acervo em exposição não basta (KÖPTCKE, 
2003; KRMAER, 1998, MOURA, 2011). Trabalhar em parceria implica ter preocupação com a expectativa do outro - compreender porque o que parece ser importante para o museu, talvez, não seja para o professor. Köptcke (2003) ressalta que é comum a opinião de que os museus precisam formar os professores para melhor utilizarem o potencial educativos dos museus e questiona "estão os profissionais dos museus preparados para receber adequadamente esse público?" (KÖPTCKE, 2003, p. 125).

Para a autora, falar em formação cultural para o professor nos espaços museológicos é falar em parceira. Educadores dos museus e das escolas possuem saberes que devem ser entrelaçados. Nessa perspectiva, o processo de formação implica, necessariamente, em: vontade de conhecer o outro; capacidade de questionar os próprios modos de ação; autocrítica; diálogo; possibilidade de autotransformação e de novas relações.

Com a adoção dessas posturas, o esforço de negociação e abertura pode valorizar a autoestima e o sentimento de responsabilidade dos envolvidos, contribuindo para que se afastem de comportamentos e preconceitos característicos de seu campo específico de atuação, proporcionando assim a construção de caminhos profícuos. No Museu de Arte do Rio foi possível perceber esse contexto de formação, a partir do seguinte relato:

Fizemos um Centro de Estudos com todas as professoras e agente educadores de uma creche e uma das perguntas que elas nos fizeram foi "Por que os bebês nunca vão? Nunca saímos com o berçário! E nós respondemos "Olha... Nunca foram porque ainda não tivemos essa experiência, ninguém nunca pediu! Vamos fazer?". Daí planejamos como faríamos a visita. Eles vieram com o ônibus do projeto "Partiu MAR" e com os pais também. Marcamos um Centro de Estudos antes com todos os professores e educadores aqui no museu. Planejamos juntos, foi um luxo! Ajudaram a pensar desde o planejamento conceitual da visita, o que poderíamos trabalhar na exposição: cor, som, forma, até questões estruturais - os professores apontaram que nós não temos nenhum fraldário dentro do espaço expositivo, só no banheiro do andar térreo. Foi um planejamento conjunto da visita olhando todos os detalhes. Como a visita também contou com os responsáveis - inclusive, foi a primeira vez que muitos deles foram a um museu -, as professoras alertaram "É importante vocês provocarem para que os bebês saiam do colo, se não eles vão querer ficar no colo dos pais a visita toda.". A partir disso, já no acolhimento, tivemos que pensar em ações para fazer no chão para estimular os bebês a sair do colo. Foi muito legal essa troca com os professores, eles nos ensinaram muitos pontos importantes (Entrevista - Clarisse/Educadora de Projetos do Museu de Arte do Rio)

Vale destacar que essa foi uma visão acerca do processo de formação compartilhada apenas pela profissional do Museu. Conhecer a opinião dos professores acerca das experiências de formação que os museus oferecem também se configura como um aspecto importante.

\section{b) Difusão do conhecimento produzido no museu acerca do público infantil}

Sobre a contribuição das instituições investigadas sobre a ampliação do conhecimento acerca do público infantil nos museus, foi possível constatar que as 
três instituições realizam esforços nesse sentido, obtendo maior e menor êxito em suas ações.

Consideram que contribuem a partir de iniciativas como cursos e eventos para educadores, programação especial para crianças, oficinas e produção de materiais educativos. Contudo, a falta de tempo (em decorrência da realização de muitas tarefas e poucos profissionais) para sistematização, registro e publicação/divulgação dessas ações representa o elo fraco mais apontado pelas coordenadoras das Instituições.

A Casa de Rui Barbosa citou como ação permanente (embora não mais existente) o desenvolvimento do curso "Museu Professor-Aluno: Uma nova forma de ver" - programa implementado de 2000 a 2005, em que recebiam os professores e trabalhavam conjuntamente as possibilidades educativas do Museu. A ideia era construir, junto com os professores, atividades que pudessem ser melhor aproveitadas pelos alunos. Realizaram também uma ação pontual, no primeiro semestre de 2016, no interior do evento "Museu de Ideias," cujo tema central foi o público infantil. O Museu desenvolve ainda outras ações planejadas pensando especificamente o público infantil, mas não há um trabalho de sistematização para que se transforme em conhecimento a ser divulgado no campo.

A reflexão sobre o público infantil o tempo inteiro é feita aqui na Casa [de Rui Barbosa], mas precisamos implementar melhor as ações para poder escrever um artigo sobre isso, para poder divulgar e amadurecer um pouco esse processo (Entrevista - Francisca / Museóloga do Museu Casa de Rui Barbosa).

A Casa da Ciência considera que contribui para a produção de conhecimento acerca do público infantil a partir das oficinas e materiais educativos que produzem e divulgam nas redes sociais, nos panfletos da Casa, nos folders, banner etc. O material "Carta às Escolas" também é elaborado pela Seção de Educação indicando sugestões sobre como, após a visita, o professor pode continuar trabalhando a temática da exposição em sala de aula.

No Museu de Arte do Rio, a contribuição acerca do público infantil nos museus se dá de quatro formas distintas: a primeira é a formação docente para os professores de E.I da prefeitura que são convocados nos concursos da Secretaria Municipal de Educação (SME). O curso conta com um dia de formação no MAR, que cede o espaço e sua equipe, e organiza uma mesa sobre Educação Infantil. A segunda forma é através do projeto "MAR na sua Rede", onde a equipe educativa realiza uma experiência de formação fora do museu - que pode ser nas escolas, universidades, instituições etc., e, geralmente, é onde o tema de trabalho com crianças e público infantil é bastante solicitado. A terceira forma de 
contribuição reside no "Programa de Formação com Professores" que, no período de 2013 a 2017, desenvolveu cinco cursos $^{66}$ com temáticas voltadas para a infância. O quarto aspecto de contribuição, destacado pelo Museu, são suas ações específicas, como os programas de férias, conversas de galeria, programação de "Dia das Crianças", dentre outras. Ao ser indagada se a Instituição publicava, trocava e difundia as práticas realizadas com as crianças, a educadora esclareceu:

Acho que essa é a nossa principal falha, é o nosso desejo. Temos um problema sério aqui - você, como pesquisadora, deve ter sentido isso - que é comum em outras instituições também: a sistematização, escrita, registro e memória de todas as nossas ações. Temos, muitas vezes, memória de fotografia porque algumas vezes contratamos filmagem, mas memória escrita e uma reflexão sobre todas as nossas práticas, não só sobre público infantil, mas sobre todas as práticas da Escola do Olhar, não temos ainda (...). E é algo que também precisamos, até porque as coisas se perdem e é importante tentarmos ter também uma autocrítica, fazer reflexões contínuas a partir da troca com outros - mas essa é uma dificuldade que temos! (Entrevista - Clarisse/ Educadora de Projetos do Museu de Arte do Rio)

Conforme explicitado no capítulo 1 (introdução), a investigação realizada por Cury (2015) apontou a carência de publicações acerca das pesquisas de público em museus. Além disso, outro ponto destacado pela autora é a não absorção pelo campo museológico das contribuições que essas poucas pesquisas realizadas podem proporcionar. A autora considera que existem dois desafios a serem enfrentados no campo: a absorção das contribuições acadêmicas nas práticas museológicas e o aumento dos estudos sobre o público que frequenta esses espaços.

Koptcke (2003) também destaca o desenvolvimento de pesquisa dos setores educativos como instrumento de conhecimento que deve ser adotado enquanto forma contínua de trabalho - um espaço de escuta e avaliação das próprias práticas. Para a autora, a realização e divulgação de pesquisas, que se debruçam sobre as ações educativas desenvolvidas com diferentes públicos, possibilitam uma revisão das práticas e a construção de novas relações. É, portanto, também uma das ações fundamentais na articulação entre museus e escolas.

\footnotetext{
66 i- Curso Museu como lugar de criança pequena (2013); ii - Curso Reflexões sobre as Relações entre Crianças Pequenas e Espaços Museais - Mergulhando Mais Fundo no 'Mar' da Infância! (2014); ii- Introdução à Musicalização e Infância (2014); iv - Oficina Práticas Artísticas Contemporâneas: Arte e a politização do brincar (2016) e v - Oficina Práticas Artísticas Contemporâneas - Infâncias, educação e práticas artísticas contemporâneas: narrativa e ficção como políticas (2017).
} 


\section{c) Divulgação das ações educativas para as escolas}

Quanto às formas de divulgação das ações educativas dos museus investigados, foi possível aferir que ocorrem, principalmente, por meio de divulgação eletrônica (páginas nas redes sociais, sites, e-mails) e material impresso (folder, filipeta, banner). Contudo, cabe questionar se essas formas de divulgação realmente têm surtido efeito, uma vez que a frequência das escolas de Educação Infantil nos museus e centros culturais da cidade ainda é reduzida. Mesmo nas instituições investigadas, a frequência desse público ao longo do ano de realização do campo foi baixa. Köptcke (2003) lança pistas que, talvez, os professores não levem suas turmas de E.I em determinados museus por não verem outras crianças frequentando seus espaços.

Uma das professoras entrevistadas no Museu de Arte do Rio, apontou que as recomendações e o "boca a boca" entre colegas são as principais formas de tomar conhecimento sobre as atividades oferecidas pelos museus ao público de E.I. Considera que falta divulgação das ações educativas para que os professores obtenham essa informação.

Analisando a fala das coordenadoras do Museu Casa de Rui Barbosa e da Casa da Ciência, as duas instituições que tiveram o menor número de visitas no período de realização do campo, foi possível perceber algumas fragilidades, como a carência na produção do material de divulgação. Cabe destacar, também, o reduzido alcance às escolas de E.I que não pertencem à rede pública de educação. Muitas vezes, os museus contam apenas com alguns professores da rede privada - que visitaram a Instituição anteriormente para divulgar suas ações - seja por e-mail pessoal cadastrado ou ao convidá-los para seguir as mídias sociais.

Estudos apontam que ainda falta uma ação eficaz nos museus e centros culturais brasileiros no que se refere à divulgação e ao incentivo à utilização das ações e programas educativos. A maioria das escolas assume a responsabilidade integral de fazer o elo entre o museu e o grupo social que compõe sua comunidade escolar (MOURA, 2011; REDDIG, 2007). Reddig (2007) considera que, talvez, seja necessário pensar até mesmo em investimento em marketing museológico para que essas instituições alcancem maior visibilidade sobre suas ações, de modo a fazer com que o público seja informado das diversas possibilidades de relação com a cultura e com o patrimônio que os museus guardam e comunicam. 


\section{5 \\ Considerações finais}

Tendo em vista que a pesquisa teve como objetivo investigar a relação entre museus e Educação Infantil, buscando perceber/compreender a experiência vivida pelos diferentes agentes nela envolvidos (crianças, professores e educadores dos museus), apresento algumas considerações que puderam ser tecidas sobre essa relação.

O primeiro aspecto investigado foi como os museus e centros culturais da cidade do Rio de Janeiro recebiam o público de Educação Infantil. A partir de um mapeamento geral sobre os museus da cidade, os dados apontaram que a frequência desse público é reduzida e a escola é o principal agente promotor desse encontro. Entretanto, a oferta de programação para E.I ainda é baixa nas instituições museológicas, principalmente para o segmento creche. Pode-se perceber a predominância dos museus históricos como as instituições que menos oferecem programação específica para esse público e os museus de arte como os espaços que mais desenvolvem esse trabalho.

A recepção à E.I engloba diferentes atividades, como contação de histórias, visitas mediadas, oficinas, jogos e brincadeiras. Entretanto, a oferta de visitas mediadas para crianças de 0 a 3 anos é reduzida quando comparada a de crianças maiores. Quanto à formação para atuar com o público infantil, foi constatado que os próprios museus afirmam desenvolver essa tarefa ou possuem profissionais com formação específica na área. Sobre a necessidade de mudanças para melhor receber as crianças, o resultado ficou, praticamente, dividido entre as instituições que apontaram a necessidade de melhorias e as que consideram que essa possibilidade não se aplica a seus espaços.

Procurando aprofundar o conhecimento sobre como os museus e centros culturais da cidade do Rio de Janeiro recebiam o público de Educação Infantil, foi realizada uma investigação em campo em três museus de tipologias distintas Museu de Arte do Rio, Casa da Ciência da UFRJ e Museu Casa de Rui Barbosa - para captar algumas especificidades sobre o modo como as instituições se preparavam (espaço/equipe/ações) para receber crianças em visitas escolares. 
Analisando os espaços expositivos das três instituições selecionadas para a pesquisa, respeitando a especificidade da temática e expografia de cada exposição, alguns elementos comuns podem ser destacados nas três instituições: a realização do trabalho com as crianças nos espaços expositivos junto à presença dos demais públicos, a não utilização de textos como foco das mediações, a busca por adaptações práticas (na linguagem dos mediadores e na redução do percurso) e a tentativa dos mediadores de mostrar que um grupo de crianças no museu não significa um risco à segurança das coleções.

Os programas e atividades oferecidos, de forma geral, eram desenvolvidos por toda a equipe, com ênfase na participação criativa dos mediadores/ estagiários. Duas instituições (MAR e Casa da Ciência), mesmo não possuindo um programa ou projeto educativo destinado especificamente para a recepção ao público infantil, demonstraram que é possível adotar boas práticas para um trabalho que busca atender as especificidades desse público.

As atividades envolviam a dimensão racional e sensível da apropriação de sentidos e significados sobre o conteúdo das exposições. Por parte das três instituições, havia a preocupação em adaptar o percurso expositivo de forma a atender aos interesses e despertar a curiosidade das crianças. Considerando a especificidade de cada instituição, os objetivos dos trabalhos realizados coadunam na perspectiva de buscar oferecer às crianças uma experiência cultural que seja capaz de estimular a curiosidade e a capacidade de criação, despertando uma memória afetiva com os espaços de cultura. As principais estratégias e metodologias de trabalho observadas foram o diálogo, a observação, as brincadeiras e o estímulo à interpretação, à comparação, à imaginação e a troca de impressões com os diferentes sujeitos envolvidos no momento da visita. O uso de questionários aos professores que visitavam os museus com suas turmas configura-se no modo de avaliação mais recorrente. Nenhuma tentativa de avaliar a experiência vivida pelas crianças havia sido implementada.

Sobre a formação dos mediadores para atuar junto ao público infantil, foi possível detectar que a formação ocorre de duas maneiras distintas: cursos e programas institucionais de formação continuada e formação compartilhada entre pares/colegas mais experientes. Por vezes, a compreensão de que o conhecimento acerca do trabalho a ser desenvolvido com as crianças é adquirido por meio da prática prevalece sobre o que é aprendido nos cursos e formação institucional. Fato que acontece, sobretudo, devido a algumas divergências da teoria que são encontradas na prática com as crianças e pelas dificuldades financeiras e burocráticas de alcançar toda a equipe nos cursos de formação. 
Outro fator detectado foi a falta de diálogo sobre a educação fora dos espaços escolares e a não contemplação da infância nos cursos de graduação (bacharelado e licenciaturas).

O segundo aspecto investigado na pesquisa foi a relação estabelecida pelos museus com o público infantil com o objetivo de identificar o que os profissionais falavam sobre o público infantil e as constatações observadas na prática. Analisando as entrevistas concedidas junto às observações realizadas, algumas características comuns aos mediadores das três instituições se destacaram, como: a crença na capacidade das crianças de estabelecer relações com as distintas temáticas dos museus; a disponibilidade de escuta atenta; o respeito e a valorização dos conhecimentos prévios das crianças; a intenção de conectar os conhecimentos das crianças com outros saberes; a habilidade de articular os comentários das crianças com informações e conhecimentos das exposições que julgavam ser relevantes; sensibilidade na linguagem, buscando se adequar às possibilidades de compreensão das crianças; o reconhecimento da importância das interações estabelecidas pelas próprias crianças na construção do conhecimento; incentivo à troca de informações e ao diálogo entre elas e os diferentes agentes da visita; a franqueza para assumir inseguranças; e o reconhecimento que ainda tinham muito a aprender na recepção ao público infantil, principalmente, com os colegas mais experientes.

Aspectos não tão positivos na relação estabelecida com as crianças também foram identificados. Nas entrevistas, foi revelada a visão de que a visita aos museus é um benefício a longo prazo - os aprendizados surtirão efeito no futuro deixando de enxergar a criança enquanto sujeito no presente. Além disso, foi possível identificar na fala dos mediadores um entendimento de "protagonismo" sobre o que transmitem às crianças, como se fossem os principais responsáveis pelo ato reflexivo, prevalecendo, até mesmo, sobre a capacidade de as crianças estabelecerem suas próprias conexões.

Alguns aspectos controversos na atuação com as crianças também foram detectados, como: formas de controle sobre o corpo e o comportamento nos espaços expositivos, a tentativa de transmitir uma "leitura correta da obra", a mediação despretensiosa referente ao reconhecimento da capacidade de leitura da obra e entendimentos sociais das crianças, ou, até mesmo, o uso de linguagens distantes/metafóricas que não ganhavam sentido para as crianças.

O terceiro aspecto investigado na pesquisa foi como as crianças reagiam à experiência museal de diferentes temáticas. Uma hipótese inicial de que o interesse, as expectativas e a articulação de saberes - a experiência estética - 
vivida pelas crianças poderia variar conforme a tipologia ou temática dos museus não foi comprovada, pelo contrário. Atenta às reações que escapavam, ao modo como reagiam e às falas proferidas entre si, com os mediadores e com os professores, foi possível perceber que experiências estéticas foram vivenciadas pelos diferentes grupos de E.I que visitaram os três museus investigados.

As crianças possuíam um entendimento sobre o que pode vir a ser um museu e o que esse local pode guardar - de objetos antigos a coisas fantásticas. As expectativas das crianças, nas três instituições, giravam em torno do museu como local de infinitas possibilidades e aventuras a serem desbravadas. Algumas noções sobre normas de conduta socialmente esperadas também foram mencionadas pelas crianças. A compreensão sobre o que não era permitido foi a mais presente.

No que concerne ao interesse pelo que era visto, foi possível perceber que, independente da tipologia do museu ou da temática abordada, o conteúdo expositivo atraia a atenção das crianças. Os aparatos tecnológicos presentes nas exposições do Museu de Arte do Rio e na Casa da Ciência também foram alvo de grande interesse. Nas três instituições, as crianças demonstraram entrosamento e interação com os mediadores e com suas propostas ao longo das visitas. Sentiam-se à vontade para fazer perguntas relacionadas ao que viam, imaginavam e suspeitavam. No contato com o acervo, deixavam curiosidade e imaginação fruir de forma a enxergar novos detalhes e construírem outras narrativas para as obras que, até então, não haviam sido consideradas pelos mediadores e professores.

Em meio à descoberta dos diferentes espaços dos museus, algumas crianças demonstraram medo. Nesses momentos, o apoio e a empatia entre pares foram fundamentais para que as crianças que estavam receosas se arriscassem a explorar novos ambientes. Por vezes, as crianças também apresentavam falta de interesse nas atividades propostas pelos mediadores.

Demonstraram, ainda, plena capacidade de articulação de saberes sobre a temática das exposições a partir do que viam no acervo e no diálogo com os mediadores e com os professores. Identificaram cores, objetos e formas geométricas. Expuseram seus entendimentos sobre casas, mobiliários, temática indígena, diferentes animais, plantas, frutas, preservação do meio ambiente, o respeito à fauna e à flora, dentre outros assuntos. As interpretações articuladas partiam da relação que estabeleciam com suas experiências anteriores e conhecimentos prévios adquiridos no âmbito familiar e escolar. 
O quarto aspecto da investigação se debruçou sobre a relação estabelecida pelos professores de E.I com as práticas educativas nos museus e centros culturais. Os professores que visitaram as instituições com suas turmas, em sua maioria, afirmaram ter o hábito pessoal de frequentar museus e consideram que houve incentivo para adotar práticas culturais com o segmento de E.I em seus cursos de formação. Quando esse incentivo não veio da formação, foi adquirido na prática docente.

A partir das entrevistas, aliadas às observações em campo, foi possível constatar que os professores reconhecem a relevância de visitar os museus por motivos distintos: ampliação da formação cultural, experiência provida no contato com os mediadores e com a linguagem expositiva; complementação dos conteúdos curriculares etc. Outro aspecto observado é que há uma dicotomia na visão docente acerca da pertinência dos museus às crianças: alguns acham que qualquer temática é válida (desde que haja uma adaptação da linguagem e da forma de tratar o tema) e outros acreditam que é preferível a relação com os museus de arte e ciência - temas que "atravessam" ou são "próprios" da infância e dos conteúdos abordados nas escolas.

Apesar de acreditarem na relevância dos museus para as crianças, a maior parte dos professores assumiu uma postura coadjuvante nas visitas. Nos grupos em que foi possível perceber a participação dos professores na mediação, conflagram-se momentos extremamente ricos na experiência formativa. Uma prática desfavorável à apropriação cultural pelas crianças e recorrente na postura dos professores foi a busca pelo controle, por vezes bastante rígido no comportamento das crianças. Em outros momentos, deixavam o grupo sob total responsabilidade dos mediadores sem demonstrar vontade em participar das atividades.

O quinto e último aspecto investigado na pesquisa buscou conhecer os principais elementos que articulam ou dificultam, efetivamente, a relação entre museus e escolas de Educação Infantil. Os principais obstáculos mencionados pelos professores foram: a dificuldade de achar museus que oferecessem um trabalho adequado às especificidades do público infantil; o excesso de burocracia; a dificuldade em providenciar transporte (na rede pública); o tempo enxuto devido à grade de conteúdos curriculares e o forte contexto de violência urbana na cidade do Rio de Janeiro.

As dificuldades apontadas pelos profissionais dos museus foram relativas a: estrutura rígida dos espaços museológicos para o desenvolvimento de atividades mais dinâmicas; dificuldade em adaptar a linguagem de forma a tornar os 
conhecimentos interessantes e acessíveis; falta de estrutura dos museus; entraves operacionais no trabalho com as escolas; resistência e incompreensão que as escolas apresentam no que se refere à capacidade de apropriação de seus conteúdos pelas crianças (nos museus de ciência e história); agendamento de visitas para, apenas, lazer ou complementação do currículo; relação estabelecida com os professores de E.I.

Dentre todos os obstáculos apontados pelos educadores da escola e do museu, foi mencionado, de forma recorrente, o quanto os cortes de verba na área da cultura vêm afetando a potencialidade educativa dos espaços culturais. Isso se reflete, principalmente, na falta de transporte e de toda uma estrutura/logística (maior equipe, formação, materiais, divulgação etc.) necessária para o desenvolvimento de um trabalho adequado com as crianças de E.I e com os demais públicos.

Dentre as mudanças apontadas para a melhoria da relação entre museus e Educação Infantil, foram elencadas necessidade de mudanças estruturais nos museus; adequações nos discursos e nos espaços expográfico; a atualização na formação dos mediadores; e a efetivação de ações que busquem aproximar professores e mediadores. Diante dessas constatações acerca dos obstáculos encontrados e das mudanças necessárias para a melhoria do trabalho a ser desenvolvido com o público infantil, foi possível elencar algumas ações a serem implementadas ou aperfeiçoadas pelos museus que também podem contribuir para a articulação entre essas instituições educativas: a divulgação das ações educativas; a difusão do conhecimento produzido no museu acerca das relações com o público infantil e a oferta de programas de formação/estudo para professores.

Diante de tantos achados, reconheço que as experiências vividas pelos diferentes sujeitos envolvidos nessa relação são únicas e não há como mensurar o que foi apreendido por cada um. Entretanto, foi válido investigar como crianças, adultos e museu se relacionavam de forma a construir novos significados e leituras de mundo. Kramer e Carvalho (2012) interrogam se crianças, jovens e adultos estão aprendendo com a cultura, com a experiência acumulada. Consideram que avaliar as ações culturais, em sua interface com a educação, implica identificar se a formação cultural, capaz de constituir sujeitos críticos, está sendo valorizada. Cabe, então, observar os aspectos estéticos e éticos da experiência que o museu e seus projetos propiciam às crianças.

Nesse sentido, avalio que os resultados obtidos com a pesquisa apontam que, para proporcionar experiências estéticas para o público infantil nos museus, 
tem sido necessário enfrentar alguns obstáculos teóricos, financeiros e estruturais. Além disso, ainda são poucas as pesquisas que se dedicam a estudar o tema. De toda forma, o estudo teórico acerca da experiência, estética, infância e museus aliado à pesquisa de campo, mostrou que a experiência estética nos espaços museais se constitui na interação com as manifestações, registros e celebração das diferentes formas de viver e estar no mundo. Portanto, considero que os museus podem ser compreendidos enquanto meio - experimental e criativo profícuo para promover experiências estéticas às crianças a partir da interação com a cultura material. Para tanto, é necessário que se amplie a troca de saberes entre museus, escola e universidade com o intuito de diminuir a lacuna entre os estudos sobre a infância e as práticas educativas com as crianças nos espaços culturais.

Retomando a perspectiva teórica de Dewey (2010), resgato a compreensão da experiência estética como um desafio ao pensamento, pois exige evocação e organização, através da imaginação, por parte daquele que a vive. Todos os elementos que constituem o sujeito, advindos de outras experiências, se fundem na experiência estética. Seu traço distintivo é, exatamente, o fato de que, nela, não existe distinção entre o eu e o objeto/meio. A experiência do ser humano é passível de uma qualidade estética, pois o mundo é uma combinação de movimento e culminância, de rupturas e reencontros. Esse movimento aconteceu nos museus observados e, igualmente, durante a construção desta pesquisa.

Inspirada nos apontamentos do autor e nas considerações de Pereira (2011) sobre a pesquisa como experiência estética, interpreto que a qualidade estética da experiência pode ser atribuída à conclusão desse estudo. Um movimento de culminância da prática de pesquisa que, além de buscar contribuir para a produção de conhecimento no campo o qual se situa, foi formadora de um modo próprio de percepção do mundo, do outro e de mim mesma. "Toda pesquisa em ciências humanas, em última instância é uma pesquisa sobre o homem e a cultura e, portanto, um trabalho em que o pesquisador, pesquisando o outro, pesquisa também a si mesmo (PEREIRA, 2011, p. 22).

A autora considera que, na medida em que a construção do objeto estudado afeta o pesquisador de tal maneira que altera suas formas de percepção, a prática de pesquisa pode ser vista como uma experiência estética. Pensar sobre a pesquisa (suas questões e respostas) deixa de ser tarefa e se torna convocação. Desta forma, reconheço que - enquanto criança que frequentou museus, professora de Educação Infantil e pesquisadora no campo da Educação - me senti convocada a conhecer a relação estabelecida entre o público de Educação Infantil 
e os museus, na tentativa de compreender quais aspectos possibilitam e dificultam esse encontro.

A conclusão do estudo, neste sentido, mais do que dar forma aos achados da pesquisa, conta também do sujeito que a produziu, que dá a si mesmo acabamento na medida em que desenha e redesenha seu objeto de estudo/ de vida. Os estudos de MARTINS, GUERRA e PICOSQUE (1998) contribuem ao elucidar que são os outros parceiros internalizados (como os teóricos que já lemos, os professores com os quais convivemos, colegas, familiares, amigos, personagens de filmes a que assistimos), as experiências que vivemos ou os conceitos que construímos que influenciam nosso contato com o mundo. Portanto, cabe reconhecer que, para o leitor desse estudo - carregado de sua história única de vida - a pesquisa desenvolvida pode ser interpretada com um sabor/saber diferente.

Ainda assim, desejo que esta tese de doutorado venha a contribuir para a reflexão sobre a práxis educativa dos profissionais da escola e do museu com o intuito de possibilitar às crianças que frequentam a Educação Infantil uma formação alicerçada em experiências imbuídas de significado ético, político e estético. 


\section{Referências bibliográficas}

ALBERNAZ, Maria Beatriz. Historiografia das atividades educativas do Museu Casa de Rui Barbosa (1930-2005). Projeto Fundação Casa de Rui Barbosa. Relatório de Pesquisa. FAPERJ, 2006

ALVES-MAZZOTI, Alda; GEWANDSZNAJDER, Fernando. O método nas ciências naturais e sociais: pesquisa quantitativa e qualitativa. São Paulo: Editora Pioneira, 1998.

BENJAMIN, Walter. Obras escolhidas 1. Magia e técnica. Arte e política. (8ª edição). São Paulo: Editora Brasiliense, 2012.

. Reflexões sobre a criança, o brinquedo e a educação. São Paulo: Duas Cidades - Editora 34, 2017.

BRANDÃO, Zaia. Conversas com pós-graduandos. 2.ed.- Rio de Janeiro: Forma \& Ação, 2010.

BRASIL. Constituição da República Federativa do Brasil. Brasília, DF: Senado Federal: Centro Gráfico, 1988.

Estatuto da Criança e do Adolescente. Lei Federal nº 8069, de 13 de julho de 1990.

BRASIL. Ministério da Educação. Lei de Diretrizes e Bases da Educação Nacional. Lei Federal no 9394, de 20 de dezembro de 1996.

Ministério da Educação e do Desporto. Secretaria de Educação Fundamental. Referencial curricular nacional para a Educação Infantil / Ministério da Educação e do Desporto, Secretaria de Educação Fundamental. - Brasília: MEC/SEF, 1998.

. Conselho Nacional de Educação. Resolução CNE/CEB n 5/2009.

Diretrizes Curriculares Nacionais para a Educação Infantil. Brasília, DF: Diário Oficial da União, 18 dez de 2009a.

Emenda Constitucional n 59, de 11 de novembro de 2009. Diário Oficial da União, Brasília, 12 nov. 2009b.

Ministério da Educação. Secretaria da Educação Básica. Base nacional comum curricular. Brasília, DF, 2016. Disponível em: $<$ http://basenacionalcomum.mec.gov.br/\#/site/inicio $>$. Acesso em: 12 junho 2018.

CAMARGO, Marcos. Princípios da aisthesis. BOCC-Biblioteca on-line de Ciência da Comunicação, 2011, p.1-14. ISSN: 1646-3137. Disponível em: www.bocc.ubi.pt>. Acesso em: 20 junho 2018. 
CARVALHO, Cristina; LOPES, Thamiris Bastos; RESINENTTI, Priscila Matos. Educação Infantil e Espaços Culturais: possibilidades de apropriação na cidade do Rio de Janeiro. Revista PERSPECTIVA, Florianópolis, v. 35, n. 1, p. 300-322, jan./mar. 2017

CARVALHO, Cristina; PORTO, Cristina. Crianças e adultos em museus e centros culturais. In: KRAMER, Sonia; NUNES, Maria Fernanda; CARVALHO, Maria Cristina (orgs.). Educação Infantil: Formação e responsabilidade. Campinas, SP: Papirus, 2013.

CARVALHO, Cristina. Criança menorzinha...ninguém merece! - políticas de infância em espaços culturais. In: KRAMER, Sonia \& ROCHA, Eloísa Candal (orgs.). Educação infantil: enfoques em diálogo. São Paulo: Papirus, 2013.

CARVALHO, Cristina et al. Ações educativas em museus e centros culturais da cidade do Rio de Janeiro. Relatório de pesquisa. Rio de Janeiro, 2015.

CARVALHO, Cristina; LOPES, Thamiris Bastos. O público infantil nos museus. Revista Educação e Realidade, Porto Alegre, v. 41, n. 3, p. 911930, jul./set. 2016.

CARVALHO, Cristina. Quando a escola vai ao museu. Campinas, SP: Papirus, 2016.

CAZELLI, Sibele. Jovens, escolas e museus: os efeitos dos diferentes capitais. In: RIBEIRO, L.C. de Q.; KOSLINSKI, M.C.; ALVES, F.; LASMAR, C. 9Org.). Desigualdades Urbanas, Desigualdades Escolares: a metrópole do Rio de Janeiro. Rio de Janeiro: Letra Capital: Observatório das Metrópoles: IPPUR/UGRJ, 2010.

CAZELLI, Sibele; COIMBRA, Carlos. Avaliar as ações educativas em museus: como, para quê e por quê?. ENCONTRO NACIONAL DA REDE DE EDUCADORES EM MUSEUS E CENTROS CULTURAIS DO ESTADO DO RIO DE JANEIRO, 1., 2007, set.17-18: Rio de Janeiro, RJ. Anais... p. 165-187. Rio de Janeiro: Fundação Casa de Rui Barbosa, 2010. 352p. (Coleção FCRB Aconteceu; 10). ISBN: 978-85-7004-301-6

CHAGAS, Mário; STORINO, Claudia. Os museus são bons para pensar, sentir e agir. Revista Musas, Vol 3, 2007.

CURY, Marília Xavier. Exposição - uma linguagem densa, uma linguagem engenhosa. In: VALENTE, Maria Esther Alvarez (ORG.). Museu de Ciência e Tecnologia - interpretações e ações dirigidas ao público. Rio de Janeiro: MAST, 2007.

DEWEY, John. Experiência e Educação. São Paulo: Editora Nacional, 1979.

A Escola e a Sociedade e A Criança e o Currículo. Lisboa: Relógio D'Água Editores, 2002.

Arte como experiência. São Paulo: Martins Fontes, 2010.

DUARTE, Rosália. Pesquisa Qualitativa: Reflexões sobre o trabalho de campo. Cadernos de Pesquisa, n. 115, p. 139-154, 2002. 
FALLON, Charlotte; CHAVEPEYER, Isabelle. Manifesto: museos de arte amigos de los niños pequenos. Bruxelas: Teatro de la Guimbarde y del FRAJE, 2013.

FLICK, Uwe. Introdução à pesquisa qualitativa. Tradução Joice Elias Costa - 3. ed. - Porto Alegre: Artmed, 2009.

FREITAS, Maria Teresa. A perspectiva sócio-histórica: uma visão humana da construção do conhecimento. In: FREITAS, M.T.; JOBIM e SOUZA, S.; KRAMER, S. (Orgs) Ciências Humanas e Pesquisa: Leituras de Mikhail Bakhtin. São Paulo: Cortez, 2003.

GABRE, Solange. Para habitar o museu com o público infantil: uma proposta de formação colaborativa entre professores da infância e profissionais do Museu Municipal de Arte de Curitiba. Tese (Doutorado em Educação) - Universidade Federal do Rio Grande do Sul. Porto Alegre, 2016.

Mediação cultural para a pequena infância: um projeto educativo no museu Guido Viaro. Dissertação (Mestrado em Patrimônio Cultural e Sociedade) - Universidade da Região de Joinville. Joinville, 2011.

GHEDIN, Evandro; FRANCO, Maria Amélia. Questões de método na construção da pesquisa em educação. - 2 ed.- São Paulo: Cortez, 2011.

GOLDENBERG, Mirian. A arte de pesquisar: como fazer pesquisa qualitativa em ciências sociais. Rio de Janeiro: Record, 2009.

HERMANN, Nadja. Autocriação e horizonte comum: ensaios sobre educação ético-estética. ljuí: Editora Unijuí, 2010.

IBRAM. Guia dos Museus Brasileiros/Instituto Brasileiro de Museus. Brasília: Instituto Brasileiro de Museus, 2011.

JAPIASSU, Hilton; MARCONDES, Danilo. Dicionário Básico de Filosofia. Rio de Janeiro: Jorge Zahar Editor, 2001.

KÖPTCKE, Luciana Sepúlveda. A análise da parceria museu-escola como experiência social e espaço de afirmação do sujeito. In: Gouvêa, Guaracira; Marandino, Martha; Leal, Maria. (orgs). Educação e Museu A construção social do caráter educativo dos museus de ciências. Rio de Janeiro: Acess, 2003.

KRAMER, Sonia. Infância, cultura contemporânea e educação contra a barbárie. Direitos Humanos na Sala de Aula. Rio de Janeiro, Novamerica, ano 6, n.63, jul.2005. n.7, 2000 .

O papel social da Educação Infantil. Textos do Brasil, Brasília:

Produção cultural e educação: Algumas reflexões críticas sobre educar em museus. In: KRAMER, Sonia; LEITE, Maria Isabel (orgs.). Infância e produção cultural. Campinas: Papirus, 1998.

KRAMER, Sonia; CARVALHO, Cristina. Dentro e Fora do Museu: de ser contemplador, colecionador, mediador. In: SANCHES, Janaína; SANTOS, Marcos Ferreira; ALMEIDA, Rogério (orgs.). Arte, Museu e Educação. Curitiba, Paraná: CRV, 2012. 
KUHLMANN JR., Moysés. Infância e Educação Infantil: uma abordagem histórica. Porto Alegre: Mediação, 2010.

LAJOLO, Marisa. Infância de papel e tinta. In: FREITAS, Marcos Cezar de. (org). História social da infância no Brasil. 8ª Ed. São Paulo: Cortez, 2011.

LEITE, Maria Isabel. Museus de Arte: Espaços de educação e cultura. In: LEITE, Maria Isabel; OSTETTO, Luciana Esmeralda (orgs.). Museu, educação e cultura: Encontros de crianças e professores com a arte. Campinas, SP: Papirus, 2005.

. Museu, criança e brincadeira: combinação possível? In: ALMEIDA, M. T. P. O brincar e a brinquedoteca: possibilidades e experiências. Fortaleza: Premius, 2011.

LIMA, Isabel. O estágio em museus de ciência: o museu como espaço de produção do conhecimento e formação. Tese (doutorado) - Pontifícia Universidade Católica do Rio de Janeiro, Departamento de Educação, 2018.

LOPES, Margareth. "A favor da desescolarização dos museus". Educação e Sociedade, v.40, dez. Campinas, 1991.

LOPES, Thamiris Bastos. O público infantil no Museu Internacional de Arte Naïf do Brasil. Dissertação (Mestrado em Museologia e Patrimônio). Universidade Federal do Estado do Rio de Janeiro; MAST, Rio de Janeiro, 2014.

MACHADO, Ana Maria. Cultura, ciência e política: olhares sobre a história da criação dos museus no Brasil. In: FIGUEIREDO, Betânia \& VIDAL, Diana (orgs). Museus: dos gabinetes de curiosidades à museologia moderna. Belo Horizonte: Argumentum; Brasília: CNPq, 2005.

MARANDINO, Martha. Educação em museus: a mediação em foco. São Paulo: FEUSP, 2008.

Interfaces na relação museu-escola. Caderno Brasileiro de Ensino de Física, Florianópolis, v. 18, n. 1, p. 85-100, jan. 2001. ISSN 2175-7941. Disponível em: $<$ https://periodicos.ufsc.br/index.php/fisica/article/view/6692>. Acesso em: 13 outubro 2018.

MARTINS, Mirian; PICOSQUE, Gisa; GUERRA, Maria Terezinha. Didática do Ensino de arte: a língua do mundo: poetizar, fruir e conhecer a arte. São Paulo: FTD,1998.

MARTINS, Luciana. A constituição da educação em museus: o funcionamento do dispositivo pedagógico por meio de um estudo comparativo entre museus de artes plásticas, ciências humanas e ciência e tecnologia. Tese (Doutorado - Programa de Pós-Graduação em Educação. Área de Concentração: Ensino de Ciências e Matemática) Faculdade de Educação da Universidade de São Paulo. São Paulo: 2011.

MEIRA, Marly. Educação estética, arte e cultura do cotidiano. In: PILLAR, Analice Dutra (org.). A educação do olhar no ensino das artes. Porto alegre: Mediação, 2011. 
MORTARA, Adriana. Públicos. In: IBRAM. Caderno da Política Nacional de Educação Museal. Brasília, DF: Instituto Brasileiro de Museus, 2018.

MOURA, Maria Lucia; FERREIRA, Maria Cristina. PROJETOS DE PESQUISA: elaboração, redação e apresentação. Rio de Janeiro. Editora: Uerj, 2005.

MOURA, Maria Teresa. Arte e infância: interações de crianças, adultos e obras de artes em museus. In: ROCHA, Eloisa A. C.; KRAMER, Sônia. (orgs.). Educação infantil: Enfoques em diálogo. Campinas, SP: Papirus, 2011.

Arte e infância: um estudo das interações entre crianças, adultos e obras de arte em museu. Dissertação (mestrado) - Pontifícia Universidade Católica do Rio de Janeiro, Departamento de Educação, 2005.

OLIVEIRA, Alessandra. Entender o outro (...) exige mais, quando o outro é uma criança: Reflexões em torno da alteridade da infância no contexto da Educação Infantil. Atas da 25 Reunião Anual da Anped, Caxambu, outubro de 2002.2 Disponível em: www.anped.org.br/reuniões/25/alessandrarottaoliveirat07.rtf. Acesso em: 15 setembro 2017.

. Museu: Um lugar para a imaginação e a educação das crianças pequenas. In: KRAMER, S. e ROCHA, E. Educação Infantil: Enfoques em diálogo. Campinas: Papirus, 2011.

OLIVEIRA, Ana Claudia de. Convocações multissensoriais da arte. In: PILLAR, Analice Dutra (org.). A educação do olhar no ensino das artes. Porto alegre: Mediação, 2011.

OSWALD, Maria Luiza. Educação pela carne: estesia e processos de criação. In: PASSOS, Mailsa Carlos Pinto; PEREIRA, Rita Ribes. (orgs.). Educação experiência estética. Rio de Janeiro: Nau, 2011.

PEREIRA, Rita M. Ribes. A pesquisa como experiência estética. In: PASSOS, Mailsa Carlos Pinto; PEREIRA, Rita M. Ribes. (orgs.). Educação experiência estética. Rio de Janeiro: Nau, 2011.

PERISSÉ, Gabriel. Estética \& Educação. Belo Horizonte: Autêntica, 2014.

PILLAR, Analice Dutra (org.). A educação do olhar no ensino das artes. Porto alegre: Mediação, 2011.

POL, Elena; ASENSIO, Mikel. La Historia Interminable: una visión crítica sobre la Gestión de Audiencias Infantiles em Museos. MUS-A Revista de los Museos de Andalucía. v. 4, 2006.

POULOT, Dominique. Museu e Museologia. Tradução Guilherme João de Freitas Teixeira. Belo Horizonte: Autêntica, 2013.

REDDIG, Amalhene; LEITE, Maria Isabel. O lugar da infância nos museus. Revista Musas, vol 3, 2007.

REDDIG, Amalhene. A infância representada nos espaços museais de Santa Catarina: reflexões sobre educação, identidade cultural, 
museus, arte e infância. Dissertação (Mestrado) - Universidade do Extremo Sul Catarinense, Criciúma (SC), 2007.

RICHTER, Sandra. Infância e imaginação: o papel da arte na Educação Infantil. In: In: PILLAR, Analice Dutra (org.). A educação do olhar no ensino das artes. Porto alegre: Mediação, 2011.

SANTOS, Maria Emília. Bebês no Museu de Arte: Processos, Relações e Descobertas. Dissertação (Mestrado em Educação) - Departamento de Educação, Pontifícia Universidade Católica do Rio de Janeiro, Rio de Janeiro, 2017.

SANTOS, Núbia Agustinha. Museu e escola: uma experiência de mediação entre as crianças de Educação Infantil e o espaço museológico. Dissertação (Mestrado) - Universidade Federal do Ceará, Faculdade de Educação, Programa de Pós-Graduação em Educação Brasileira, Fortaleza (CE), 2010.

SECRETARIA DE ESTADO DE CULTURA DO RIO DE JANEIRO. Museus RJ: um guia de memórias e afetividades. Rio de Janeiro: Secretaria de Cultura de Estado do Rio de Janeiro, 2013.

SHAFFER, Sharon. E. Engaging Young Children in Museums. New York: Routledge, 2015.

SOFKA, Vinos. A pesquisa no museu e sobre o museu. Revista Museologia e Patrimônio, vol 2, no1, 2009.

VALENTE, Maria Esther. Educação e Museus: a dimensão educativa do museu. In: GRANATO, M.; SANTOS, C. P. dos; LOUREIRO, M. L. N. (Org.). Museu e Museologia: interfaces e perspectivas - MAST Colloquia, 1.ed. Rio de Janeiro: Museu de Astronomia e Ciências Afins, 2009, v. 11, p. 83-98. Disponível em: <http://www.mast.br/livros/mast_colloquia_11.pdf>. Acesso em: 18 setembro 2018.

VECCHI, Vea. Estética y aprendizaje. In: HOYUELOS, Alfredo. La estética em el pensamiento y obra pedagógica de Loris Malaguzzi. Barcelona: Octaedro; Rosa Sensat, 2006.

VIGOTSKI, Liev. Psicologia da Arte. São Paulo: Martins Fontes, 1998.

Psicologia Pedagógica. Porto Alegre: Artmed, 2003.

Imaginação e criação na infância: ensaio pedagógico: livro para professores. São Paulo: Ática, 2009.

WAGENSBERG, Jorge. Museu pra criança ver (e sentir, tocar, ouvir, cheirar e conversar). In: MASSARANI, Luisa (ed.). Ciência e criança: a divulgação científica para o público infanto-juvenil. Editado por Luisa Massarani. - Rio de Janeiro: Museu da Vida / Casa de Oswaldo Cruz / Fiocruz, 2008. 


\section{Apêndices}

\section{Apêndice 1- Museus e centros culturais da cidade do Rio de Janeiro que possuíam programação específica para Educação Infantil em}

\section{5.}

Quadro 4: Museus e centros culturais da cidade do Rio de Janeiro que possuíam programação específica para Educação Infantil em 2015

\begin{tabular}{|l|l|}
\hline \multicolumn{1}{|c|}{ TIPOLOGIAS } & \multicolumn{1}{|c|}{ INSTITUIÇÕES } \\
AUTODECLARADAS & 1-Casa da Ciência \\
\hline Ciência & 2-Espaço Ciência Viva \\
Ciência e tecnologia & 3-Museu da Vida /FIOCRUZ \\
Meio Ambiente & 4-Museu da Geodiversidade \\
Planetários & 5-Museu do Meio Ambiente /JBRJ \\
Ciências biológicas & 6-Fundação Planetário \\
& 7-Museu de Ciências da Terra \\
& 8-Jardim Zoológico \\
& 9-Museu Aeroespacial \\
\hline Histórico & 1-Memorial Municipal Getúlio Vargas \\
Militares & 2-Centro Cultural Jerusalém \\
Museus-Casa & 3-Museu Casa de Rui Barbosa \\
Memória & 4-Diretoria do Patrimônio Histórico e Documentação da \\
Religioso & Marinha (Ilha Fiscal) \\
História Antiga & 5-Museu da Brigada Infantaria Paraquedista \\
& 6-Casa do Patrimônio Ferroviário do Rio de Janeiro (antigo \\
& Museu do Trem) \\
& 7-Centro Histórico e Cultural do Corpo de Bombeiros Militar \\
& do Estado do Rio de Janeiro \\
& 8-Museu Venerável Irmandade de Nossa Senhora da Penha \\
& de França \\
\hline Arte & 1-Museu Casa do Pontal \\
Moderna & 2-Museu Internacional de Arte NAIF \\
Contemporânea & 3-Fundação Eva Klabin \\
Clássica & 4-Centro Cultural Banco do Brasil \\
Popular & 5-Museu Nacional de Belas Artes \\
Temática & 6-Museu do Açude \\
& 7-Museu de Arte Moderna \\
& 8-Museu Bispo do Rosário Arte Contemporânea \\
& 9-Casa Daros \\
& 10-Centro Nacional de Folclore e Cultura Popular \\
& 11-Museu de Arte do Rio \\
\hline Comunitários & 2-Museu de Favela Maré \\
\hline
\end{tabular}




\section{Apêndice 2- Roteiro de entrevista com professores}

DATA:

MUSEU:

ENTREVISTADO (NOME/PSEUDÔNIMO NA PESQUISA):

ESCOLA:

1. Você possui o hábito de frequentar museus fora de sua prática profissional?

2. Costuma frequentar museus com suas turmas de Educação Infantil? Por quê?

3. O que o motivou a visitar o museu com sua turma?

4. Considerou relevante a visita para as crianças? Por quê?

5. Existe preferência por algum tipo específico de museu para visitar com sua turma? Por quê?

6. Na sua formação docente houve algum estímulo para frequentar esses espaços?

7. Considera que existe alguma dificuldade na relação entre museus e escolas de Educação Infantil? 


\section{Apêndice 3 - Roteiro de entrevista com mediadores}

DATA:

MUSEU:

ENTREVISTADOS (NOME/PSEUDÔNIMO NA PESQUISA):

TEMPO DE ATUAÇÃO NO MUSEU:

FORMAÇÃO:

1- Como são elaboradas as visitas/ propostas de mediação para esse público?

2- Quais aspectos consideram importantes no trabalho de mediação com o público de Educação Infantil?

3- Existe alguma dificuldade no momento de realizar a mediação com esse público? Qual?

4- Receberam alguma formação específica no museu para a receber o público infantil? Qual? Consideram suficiente?

5- Consideram que as crianças de 0-6 anos conseguem estabelecer alguma relação com o conteúdo das exposições? Qual? Como percebem isso?

6- Consideram que a visita ao museu traz algum benefício para as crianças? Qual?

7- O que podem dizer sobre a relação estabelecida com os professores de Educação Infantil que visitam o museu com suas turmas?

8- Consideram necessária alguma modificação no trabalho junto ao público de Educação Infantil? 


\section{Apêndice 4 - Roteiro de entrevista com coordenadores dos setores educativos}

DATA:

MUSEU:

ENTREVISTADO (NOME/PSEUDÔNIMO NA PESQUISA):

FUNÇÃO:

\section{SETOR EDUCATIVO E RECURSOS HUMANOS}

1.1 Existe setor educativo na instituição? Quando se estruturou?

1.2 Atualmente como se estrutura o setor/equipe que realiza as ações educativas na instituição? (quantidade de profissionais, formação profissional, divisão do trabalho).

1.3 Como é a estrutura física desse setor? (sala de funcionários, sala de atividades para o público, material para atividades, equipamentos audiovisuais etc.).

1.4 Identifica dificuldades na relação entre museus e escolas de Educação Infantil? Quais?

\section{PÚBLICO INFANTIL}

2.1 Quando teve início o programa que recebe o público de Educação Infantil?

2.2 Que profissionais/setores participam da elaboração dos programas/atividades/ações educativas para crianças?

2.3 Que profissionais/setores realizam as atividades/ações educativas?

2.4 Existe alguma formação específica para a equipe receber o público infantil? Como é realizada?

2.5 A exposição é concebida pensando a inclusão do público infantil ou ocorre um trabalho de adaptação das visitas ao espaço?

2.6 A instituição contribui de alguma forma para o conhecimento acerca do público infantil em museus? (disseminação de pesquisas, estudos do público, cursos para professores, confecção de materiais educativos etc.).

2.7 Existe algum obstáculo/dificuldade no trabalho com o público infantil?

2.8 Considera que as crianças de 0-6 anos conseguem estabelecer alguma relação com o conteúdo das exposições? Em caso positivo, qual?

2.9 Considera que a visita ao museu traz algum benefício para crianças dessa faixa etária? Em caso positivo, quais?

2.10Considera necessária alguma modificação no trabalho realizado com esse público? 


\section{ATIVIDADES REALIZADAS}

3.1 Existem programas/projetos educativos desenvolvidos especificamente para o público de Educação Infantil?

3.2 Existem aspectos da exposição priorizados nas visitas com o público de Educação Infantil?

3.3 Em quais espaços é realizado o trabalho?

3.4 $\bigcirc$ que a instituição pretende provocar nas crianças com o trabalho desenvolvido?

3.5 Existe alguma avaliação do trabalho?

3.6 Possuem cursos/encontros com os professores de Educação Infantil?

3.7 Existem reformulações das atividades oferecidas para esse público? Com qual periodicidade?

3.8 As ações educativas do museu para o público infantil são divulgadas para as escolas? Como? 


\section{Apêndice 5 - Roteiro de observação}

DATA:

MUSEU:

HORÁRIO:

RESPONSÁVEL PELA VISITA (FUNÇÃO):

ESCOLA:

( ) Pública ( ) Particular

QUANTIDADE DE CRIANÇAS:

FAIXA ETÁRIA DAS CRIANÇAS:

QUANTIDADE DE RESPONSÁVEIS:

ATIVIDADE REALIZADA:

\section{Tópicos a serem observados - Crianças:}

- Que características são observáveis nas atitudes das crianças a partir da mediação com outras crianças, com os adultos e com o espaço do museu? (O que expressam as crianças durante a visita? O que dizem? Como se comportam?)

- Que interpretações dos objetos conseguem articular? (Contextos físico, pessoal e social emergem em suas expressões?)

- O que despertou maior interesse das crianças durante a visita?

- Há alguma manifestação/fala do grupo (crianças) quanto à possibilidade de retornar (ou não) ao museu sem a presença da escola?

\section{Tópicos a serem observados - Educadores dos Museus:}

- Quais concepções de infância são expressas durante a visita?

- Quais estratégias são utilizadas pelos educadores para atuar junto às crianças?

- O educador estimula o posicionamento crítico das crianças?

- Durante a visita o educador dá oportunidades para que as crianças expressem livremente suas ideias?

- O educador favorece a interação social da criança com seus pares, com os adultos e com o espaço do museu?

\section{Tópicos a serem observados - Atividades:}

- Há algum procedimento antes da visita com as crianças? (combinados, roda de conversa, atividades)

- Linguagens de apoio são utilizadas? (textos, painéis, etiquetas, ilustrações recursos gráficos, eletrônicos etc.). 
- Existe, durante a visita, algum espaço/momento para as crianças desenvolverem alguma forma de produção cultural? (considerar as diferentes linguagens: verbal, plástica, musical, literária etc.).

- Quais são as ações/ metodologias utilizadas no momento da visita? (observar diferentes faixas etárias)

\section{Tópicos a serem observados - Professores:}

- Como o professor se relaciona com as crianças durante a visita?

- Como o professor se relaciona com os educadores do museu durante a visita?

- Como o professor se relaciona com o conteúdo/espaço da exposição?

\section{Tópicos a serem observados - Espaco Expositivo:}

- Espaços de realização da visita

- Tamanho/altura do acervo

- Possibilidades de mobilidade / autonomia / experimentação / brincadeira

- Aparatos/dispositivos oferecidos

- Reação de outros visitantes ao presenciarem o trabalho educativo do museu com o público de Educação Infantil 


\section{Apêndice 6 - Termo de consentimento livre e esclarecido}

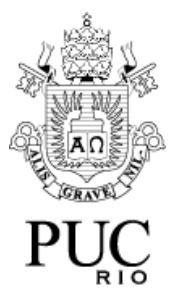

PONTIFÍCIA UNIVERSIDADE CATÓLICA DO RIO DE JANEIRO

Programa de Pós-Graduação em Educação

TERMO DE CONSENTIMENTO LIVRE E ESCLARECIDO

Prezado:

Convidamos V.S. ${ }^{a}$ a participar voluntariamente da pesquisa apresentada a seguir.

\section{Pesquisa: A EDUCAÇÃO INFANTIL E OS MUSEUS DA CIDADE DO RIO DE JANEIRO \\ Pesquisadores: \\ Doutoranda: Thamiris Bastos Lopes (thamiris_bl@hotmail.com; Tel. (21) 997222414) \\ Orientadora: Prof. ${ }^{a}$ Dr. ${ }^{a}$ Cristina Carvalho (cristinacarvalho@puc-rio.br)}

Justificativa: A crescente demanda por iniciativas que contemplem as crianças da Educação Infantil em diferentes espaços culturais e o desenvolvimento de programas em museus que buscam atender esse público em sua programação demandam um estudo que busque compreender tais ações.

Objetivo: Conhecer o atendimento oferecido ao público de Educação Infantil em alguns museus de diferentes tipologias da cidade do Rio de Janeiro, buscando compreender quais aspectos possibilitam ou dificultam a relação educativa nesses espaços.

Metodologia: Entrevistas, com registro através de áudio-gravação.

Riscos e Benefícios: Não há riscos físicos ou morais previstos e a pesquisa visa contribuir com estudos sobre o público de Educação Infantil nos museus.

$\mathrm{Eu}$, de maneira voluntária, livre e esclarecida, concordo em participar da pesquisa acima identificada. Estou ciente dos objetivos do estudo, dos procedimentos metodológicos, dos possíveis desconfortos com o tema, das garantias de confidencialidade e da possibilidade de esclarecimentos permanentes sobre os mesmos. Fui informado de que se trata de uma pesquisa de doutorado em andamento no Programa de Pós-Graduação em Educação da PUC-Rio. Está claro que minha participação é isenta de despesas e que minha imagem e meu nome não serão publicados sem minha prévia autorização por escrito. Estou de acordo com a áudio-gravação da entrevista a ser cedida para fins de registro acadêmico. Estou ciente de que, em qualquer fase da pesquisa, tenho a liberdade de recusar a minha participação ou retirar meu consentimento, sem penalização alguma e sem nenhum prejuízo que me possa ser imputado.

Thamiris Bastos Lopes, doutoranda.

Prof. - Dr. a Cristina Carvalho, orientadora.

\section{(Assinatura do voluntário)}

Nome completo:

E-mail:

Tel.

Identificação (RG):

Rio de Janeiro, de de

OBS.: Este termo é assinado em 2 vias, uma do voluntário e outra para os arquivos dos pesquisadores. 